University of Louisville

ThinkIR: The University of Louisville's Institutional Repository

$5-1998$

\title{
The Ottoman Navy 1900-1918 : a study of the material personnel and professional development of the Ottoman Navy from 1900 through the Italian, Balkan, and first World Wars.
}

Karl Wilhelm Augustus Darr

University of Louisville

Follow this and additional works at: https://ir.library.louisville.edu/etd

Part of the Islamic World and Near East History Commons, and the Military History Commons

\section{Recommended Citation}

Darr, Karl Wilhelm Augustus, "The Ottoman Navy 1900-1918 : a study of the material personnel and professional development of the Ottoman Navy from 1900 through the Italian, Balkan, and first World Wars." (1998). Electronic Theses and Dissertations. Paper 2822.

https://doi.org/10.18297/etd/2822

This Master's Thesis is brought to you for free and open access by ThinkIR: The University of Louisville's Institutional Repository. It has been accepted for inclusion in Electronic Theses and Dissertations by an authorized administrator of ThinkIR: The University of Louisville's Institutional Repository. This title appears here courtesy of the author, who has retained all other copyrights. For more information, please contact thinkir@louisville.edu. 
A STUDY OF THE MATERIAL PERSONNEL AND PROFESSIONAL DEVELOPMENT OF THE OTTOMAN NAVY FROM 1900 THROUGH THE ITALIAN, BALKAN, AND FIRST WORLD WARS

BY

KARL WILHELM AUGUSTUS DARR

B.A., UNIVERSITY OF LOUISVILLE, 1992

\author{
A THESIS \\ SUBMITTED TO THE FACULTY OF THE \\ GRADUATE SCHOOL OF THE UNIVERSITY OF LOUISVILLE \\ IN PARTIAL FULFILLMENT OF THE REQUIREMENTS \\ FOR THE DEGREE OF
}

MASTER OF ARTS

DEPARTMENT OF HISTORY

UNIVERSITY OF LOUISVILLE

LOUISVILLE, KENTUCKY 
THE OTTOMAN NAVY 1900-1918

A STUDY OF THE MATERIAL PERSONNEL AND PROFESSIONAL DEVELOPMENT OF THE OTTOMAN NAVY FROM 1900 THROUGH THE

ITALIAN, BALKAN, AND FIRST WORLD WARS

BY

KARL WILHELM AUGUSTUS DARR

B.A., UNIVERSITY OF LOUISVILLE, 1992

A THESIS APPROVED ON

98 maR 25

BY THE FOLLOWING READING COMMITTEE
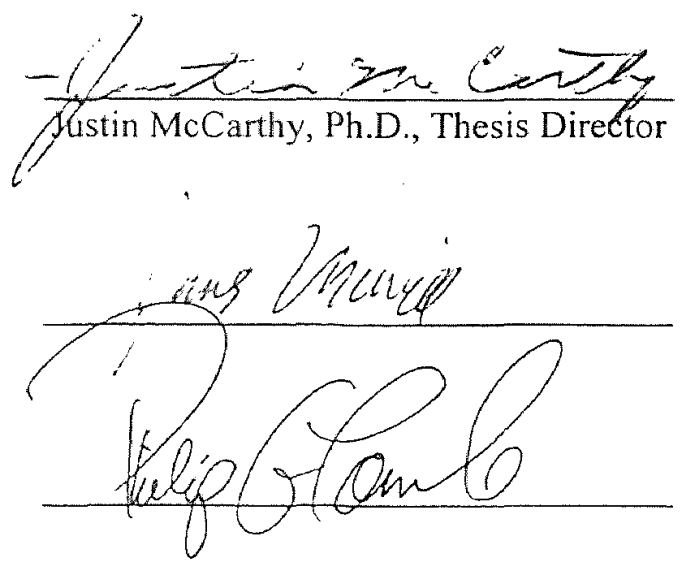


\begin{abstract}
As seafaring states evolve into nations and nations into empires, the power that protects such maturation is seapower. Geographic isolation via deserts or seas can obtain time for political and social evolution. However, only a formidable naval presence can ensure external security in order that internal reforms take root. No major modern power has survived without an adequate indigenous navy. This doctrine holds true especially in reviewing the navy of the Ottoman Empire in the early twentieth century.

In this thesis, I show that the absence of tangible fleet units cost the Ottoman Empire not only the peripheries of the state, but also the opportunity at political evolution. Covered in this thesis will be the Ottoman naval assets available at the turn of the twentieth century and how such assets were obtained. Also covered is the conduct of bordering states when Istanbul's political reformers realized that lacking naval power invited waterborne aggression, and how those efforts to correct deficiencies became a causation for war. Finally, this thesis reviews the military success and failure of the Ottoman navy and how the outcome affected the future of the Empire.
\end{abstract}




\section{ACKNOWLEDGEMENTS}

The author gratefully acknowledges the assistance of Professor Justin McCarthy for the loan of materials from his personal collections. Without such materials, this thesis would have been untenable. The author wishes to express his thanks to Dr. Leonard P. Curry for his ever-present advice and counsel. For Dr. Curry not only advised, but also encouraged the author to endeavor to write, to cite, and to believe that what I was doing had merit. The author also wishes to thank Dr. James R. Morrill for his critical review of this thesis. His unselfish experience made the completion of this paper possible. The author would also like to thank Mr. Mehmet Yalcin of the Turkish Naval Museum, Istanbul, for providing resources not available in the United States. The author would like to thank Ms. Ann Hassinger of the United States Naval Institute for her patience and assistance. The author would also needs to thank Mr. David Williams for for his expertise. Finally, I would like to thank God for giving this old salt the children who encouraged their father to follow his quest over the ridicule of those around him. 


\section{TABLE OF CONTENTS}

\section{PAGE}

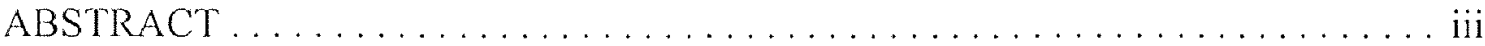

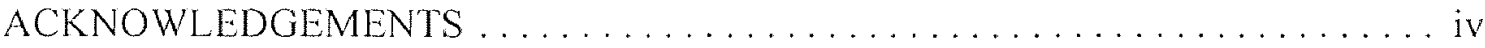

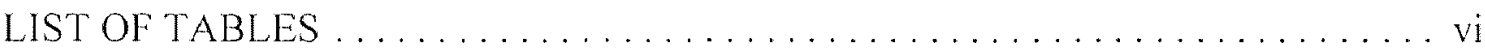

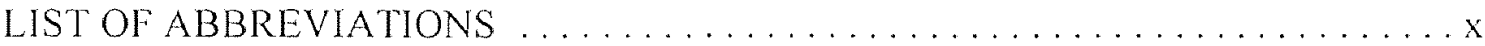

CHAPTER

I. OTTOMAN NAVAL SITUATION, 1900-1912 .................. 1

II. ITALO/OTTOMAN WAR, SEPTEMBER 1912 TO OCTOBER $1913 \ldots \ldots .24$

III. THE BALKAN WARS, OCTOBER 1912 TO OCTOBER $1913 \ldots \ldots \ldots .68$

IV. OTTOMAN BATTLESHIP ACQUISITION $\ldots \ldots \ldots \ldots \ldots \ldots \ldots \ldots 117$

V. NAVAL AVIATION AND SUBMARINES .................. 162

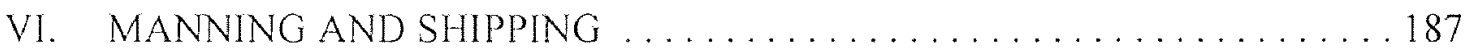

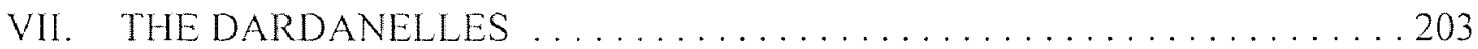

VIII. BLACK SEA ACTION, 1914-1918 .......................226

IX. SUMMARY AND CONCLUSION .......................283

BIBLIOGRAPHY

APPENDIX 1. MAP OF THE OTTOMAN EMPIRE, 1800 
APPENDIX 2. MAP OF THE CENTRAL MEDITERRANEAN DURING THE ITALO/OTTOMAN WAR, 1911

APPENDIX 3. OTTOMAN FLEET ORGANIZATION, OCTOBER 1911

APPENDIX 4. OTTOMAN FLEET DISPOSITION, OCTOBER 1912

APPENDIX 5. MAP OF THE AGEAN REGION

APPENDIX 6. ENGAGEMENT BETWEEN GREEK AND TURKISH FLEETS, DECEMBER 1912

APPENDIX 7. ENGAGEMENT BETWEEN GREEK AND OTTOMAN FLEET, JANUARY 1913

APPENDIX 8. OTTOMAN MINE LINES IN THE DARDANELLES, 1915

APPENDIX 9. MAP OF THE BLACK SEA

APPENDIX 10. OTTOMAN FLEET DISPOSITION, OCTOBER 1914 VITA 
Table

Page

1 NAVAL FORCES CONIRONTING THE OTTOMAN EMPIRE

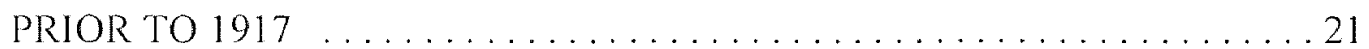

2 GROWTH OF THE ITALIAN FLEET, $1900-1910 \ldots \ldots \ldots \ldots \ldots \ldots$

3 ITALIAN AND OTTOMAN NAVAL FORCES AT THE START OF THE ITALO-OTTOMAN WAR .................... 42

4 COMPOSITION OF THE MEDITERRANEAN ITALIAN FLEET . . . . . 43

5 OTTOMAN NAVAL ASSETS LOST DURING THE ITALIAN WAR . . . 64

6 ADDITION TO THE GREEK FLEET, $1900-1912 \ldots \ldots \ldots \ldots \ldots$

7 GREEK WARSHIP ORDERS AT THE OUTBREAK OF THE

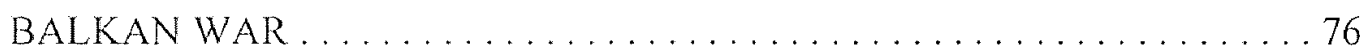

8 GREEK SHIPS SEIZED BY THE OTTOMANS, OCTOBER $1912 \ldots \ldots 1$

9 OTTOMAN NAVAL ASSETS COMPARED TO THE BALKAN

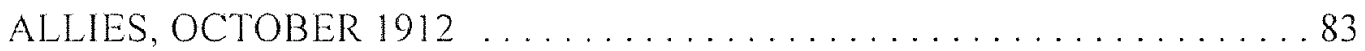

10 OTTOMAN BLACK SEA TROOP TRANSPORTS, $1912 \ldots \ldots \ldots \ldots$

11 SEA OF MARMARA TROOP TRANSPORTS, SEPTEMBER $1912 \ldots . \ldots 91$

12 GREEK SEIZURES OF MAJOR OTTOMAN AEGEAN ISLANDS . . . . 93

13 OTTOMAN FLEET ORGANIZATION, 20 DECEMBER $1912 \ldots \ldots 5$ 
14 AMMUNITION CONSUMPTION DURING THE SARPOY LANDING . . 105

15 OTTOMAN NAVAL LOSSES - FIRST AND SECOND BALKAN

WARS

16 REGIONAL NAVAL BUDGETS AND CHANGES, 1912-1914 . . . . 116

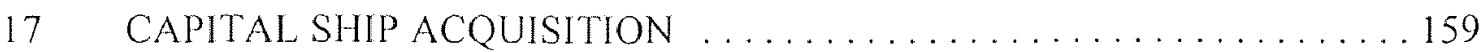

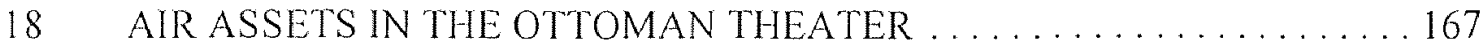

19 ENTENTE SEAPLANE TENDERS IN THE DARDANELLES . . . . . . . 169

20 RUSSIAN BLACK SEA SEAPLANE TENDERS . . . . . . . . . . 172

21 RUSSIAN OFFENSIVE MINING FIGURES . . . . . . . . . . . 172

22 GERMAN AID TO OTTOMAN AIR ASSETS . . . . . . . . . . 177

23 RUSSIAN LOSSES TO GERMAN SUBMARINES IN THE

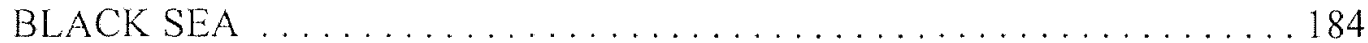

24 OTTOMAN SHIP BILLET REQUIREMENTS . . . . . . . . . . . . 191

25 OTTOMAN LOSSES TO RUSSIAN BLACK SEA MINES . . . . . . . . 201

26 OTTOMAN MINEFIELDS AS OF 8 MARCH $1915 \ldots \ldots \ldots \ldots \ldots$

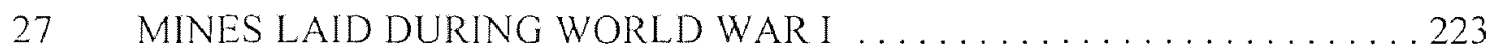

28 OTTOMAN GUN AND AMMUNITION AFTER 18 MARCH $1915 \ldots 224$

29 PROPOSED EXPANSION OF THE RUSSIAN BLACK SEA FLEET _ . . 232

30 OTTOMAN-RUSSIAN NAVAL COMPARISON ............ 234

31 RUSSIAN MINES USED IN THE BLACK SEA . . . . . . . . 247

32 OTTOMAN SHIP LOSSES IN THE BLACK SEA . . . . . . . . . . . . 279

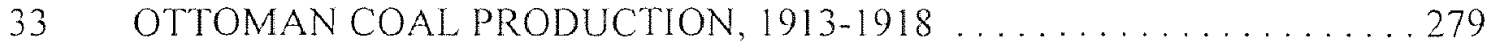


34 RUSSIAN SHIP LOSSES IN THE BLACK SEA . . . . . . . . . . . . 281

35 OTTOMAN NAVAL MINISTERS, $1900-1919 \ldots \ldots \ldots \ldots \ldots \ldots \ldots 284$ 


\section{LIST OF ABBREVIATIONS}

C.U.P.

Committee of Union and Progress

E.M.R.O. External Macedonian Revolutionary Organization

H.M.I.R.S. His Majesty's Imperial Russian Ship

H.M.S. His Majesty's Ship (United Kingdom)

I.M.R.O. Internal Macedonian Revolutionary Organization M.S Motor Ship M.V Motor Vessel

R.I.S. Royal Italian Ship S.M.S. His Majesty's Ship (Imperial Germany) S.S. Steam Ship (civilian) U.S.S. United States Ship 


\section{CHAPTER I}

\section{O'TTOMAN NAVAL SITUATION, 1900-1912}

The sea had been the lifeline of the Ottoman Empire since the fall of Constantinople on 29 May 1453.' The spread of Islam went along with shipborne trade and piracy. Under Sultan Suleiman II (1520-1556), the Ottoman Empire reached its zenith, but an empire reaching from Algiers in the Mediterranean to Aden on the Red Sea around to Sinbad's Bussorah on the Persian Gulf and the entire Black Sea region needs to control the sea lanes. It would be a secure empire as long as no power possessed a naval force capable of projecting both land and sea power into the Sultan's realm. See Appendix I. The Ottoman defeat at Azov by the little fleet of Peter the Great of Russia was a precursor to imperialist seizures in the nineteenth and twentieth century. ${ }^{2}$

In the sixteenth century, Ottoman shipbuilders had enjoyed a fine reputation, but the navy, like the empire, had failed to keep up with the latest technology. By the twentieth century, the constraints of economics, the progression of naval science, and the internal/external political situation left the Sultan's subjects with a naval force incapable 1943), 12.

'Phillip Paneth, Turkey: Decadence and Rebirth (London: Alliance Press, Ltd.,

${ }^{2}$ Virginia Cowels, The Romanovs (London: Harper \& Row, 1971), 34. Also, see Felix Gromov, Fleet Admiral, Russian Federation Navy, "After Three Centuries," Proceedings (October 1996), 42-46. 
of defending the empire. The inability of the Ottoman navy to control the intrusion by hostile forces and the loss of sea lanes condemned the empire. The Ottoman Empire's enemies could and did pick the most advantageous sites to attack, all with little concern for possible retaliation by Ottoman naval forces. Compounding the problem, failure to secure sea lanes forced Ottoman ground forces to transit via undeveloped land routes, away from possible hostile naval gunfire, delaying distant forces to an extent that when such forces did arrive in theater, in several cases the conflict had been decided. This had been the case in the Greek-Ottoman War of 1897, the Italian-Ottoman War of 1911-1912, and the Balkan Wars of 1912-1913.3

Controlling the sea has been the linchpin in empire building. Alfred Thayer Mahan, writing in The Importance of Sea Power, clearly defines the consequences of neglecting a naval force capable of securing one's coast, that being the loss of the peripheries until a country under attack is enveloped by enemies. No modem empire has lasted that did not invest resources into indigenous industries capable of supporting native shipbuilding. A political state at peace and with secure borders may be able to obtain naval forces along with expertise to utilize such assets from abroad, but this is only temporary. Governments that may try to acquire hardware and experience abroad are subject to political extortion and the difficulties of mismatched systems, replacement parts and repair facilities. This was the crux of the Ottoman naval situation on the eve of World War I.

${ }^{3}$ Ahmet Guleryüz and Bernd Langensiepen, trans. by James Cooper, The Ottoman Steam Navy, 1828-1923 (Annapolis, MD: Naval Institute Press, 1995), 7-19. 
The term "naval assets" encompasses all the facets that create a navy. This includes ships, bases, personnel, and infrastructure to support operations. The twentieth century dawned upon an Ottoman fleet wholly unable to fulfill the basics of any naval operation with the naval assets available. The Ottoman Navy in 1876 was ranked fourth largest in the world. In order to maintain the fleet, two hundred British workmen toiled at the arsenal on the Golden Horn, repairing and constructing ships for the Sultan's needs. In 1876, when Sultan Abdul Aziz (1861-1876) was deposed, Ottoman fleet personnel were involved in a large share of the revolution. Abdul Aziz was succeeded by Sultan Murad (1876), who proved unable to reign, and Abdul Hamid rose to power. Sultan Abdul Hamid II (1876-1909) feared the armed forces and wanted to prevent a popular uprising led by the military. Apart from units surrounding the Istanbul garrison, well equipped in order to impress foreign diplomats, the armed forces were neglected. The Ottoman fleet and the foreign support that maintained it were allowed to decline so that within five years of Abdul Hamid"s accession, all the British support personnel were sent home except for a small advisory mission. The warships stationed at Istanbul were forbidden to train or conduct operations and not once were fleet units allowed to venture outside the Dardanelles. ${ }^{4}$

Abdul Hamid, began to consolidate power by removing ministers in place under Abdul Aziz with the exception of the Minister of Marine, Hassan Pasha. Sir Edwin Pears notes in Forty Years in Constantinople 1873-1915 that Hassan was a brave, bluff

${ }^{4}$ Sir Edwin Pears, Forty Years in Constaninople 1873-1915 (New York: D. Appleton and Company, 1916), 170-171. 
sailor who did not fear the Sultan. Under Hassan, the naval schools languished and fleet operations were non-existent. The inactivity of the fleet and the irreverence shown to the Sultan's person would suggest that the Minister of Marine had some leverage on Abdul Hamid. During most of Abdul Hamid's reign, the Ottoman government was an autocracy, and the Sublime Porte subservient. ${ }^{5}$ The naval budget prior to the reinstitution of parliamentary oversight in 1909 was entirely up to the discretion of the Sultan. W.S. Monroe, in his book, Turkey and the Turks, quotes the Englishman Sir Edgar Vincent's report on Ottoman finances and states that 1905 expenditures of $\$ 95,000,000$ resulted in a naval budget of $\$ 3,000,000$ : less than four percent of government expenditures. ${ }^{6}$

The German Vice-Admiral von Hofe and British Admiral Henry Wood conducted an inspection of the Ottoman fleet in April and May 1897. This report revealed the extent of neglect under Abdul Hamid. The guns on all the ships of the Osmaniye class were useless, with runners on the Armstrong guns immovable, and hydraulic pistons on the Krupp quick-firing guns bent. Some ships did not have the complete armament installed upon turnover from the builder. One example was the lack of breaches for the $240 \mathrm{~mm}$ guns on the Aziziye, which were still lying at the arsenal in Istanbul. The training of gun crews had been so neglected that it took over two hours to load, train, fire, and reload the

'The Sublime Porte was originally the gateway to the palace where the Sultan or the Grand Vizier conducted business. the metonymy became official and the expression came to mean the Ottoman government itself, or the Empire. It was frequently abbreviated to "the Porte." See David Walder, The Chanak Affair (London: The Macmillan Company, 1969), 11. 143.

"W.S. Monroe, Turkey and the Turks (Boston: L.C. Page and Company, 1907), 
Armstrong guns found on most large combatants. To compound the situation, the fleet passage from the fleet anchorage at Halic to Lapseki took place in full view of foreign observers, showing the European diplomats the true state of the Ottoman fleet. ${ }^{7}$

The inspection of the Ottoman fleet at Canakkale gave Hofe the opportunity to witness gun training by "experienced" crews. Hofe noted that few crews were able to train the guns properly and that the time required to load and train the guns would be ample to allow any enemy to approach the Ottoman fleet without difficulties or danger. The poor showing of the fleet dictated a return to the safety of the fleet anchorage at Halic on 15 May $1897 .{ }^{8}$ The inspection by Hofe and Wood resulted in a recommendation for expansion of the fleet. Recommended was the modernization of armored warships and the construction of six cruiser-types abroad. After the report was presented to Abdul Hamid, there followed a series of diplomatic intrigues and industrial double dealings, with the Sultan playing off one potential supplier of warships against another.

During the civil unrest of the late 1890s in the East and the Greek regions, compensation claims from Western nationals had been submitted but not resolved. The Porte, at the instigation of the Sultan, refused to pay, maintaining that foreign influences incited much of the unrest and thus were not entitled to remuneration. ${ }^{9}$ Western Powers implied force would be employed to obtain compensation and the Sultan recanted, nevertheless, the method Abdul Hamid employed allowed the Ottomans to avoid

'Guleryüz, 9.

${ }^{8}$ Ibid.

'Pears, 172. 
recognizing the validity of such demands. He had a reputation for cleverness that exhibited itself clearly when addressing compensation claims. In order to satisfy the demands of the Western Powers, Abdul Hamid ordered ships from the nations submitting compensation claims and allowed for a generous mark up to cover damaged property. The Sultan needed to avoid direct responsiblity for the civil unrest inorder to perserve the Ottoman Empire. He requested advice from London on how to handle the Caucasus region in the belief such an appeal would temper Russian demands to protect nonMuslims in the Ottoman Empire. England used the request as a pretence with Russia to dismember the Ottoman Empire into spheres of influence. Russia deemed the Black Sea basin and the area down to Baghdad was St. Petersburg's, and England viewed the remaining of Abdul Hamid's possessions as London's to exploit. ${ }^{10}$

The Porte had planned on submitting the recommended naval plan to Western Powers at one time but the British naval advisors tipped off the Thames Iron Works as to the commissioners' plans. The British shipbuilders offered to take over the Tersane-i Amire naval shipyard at Istanbul on lease for five million lira for a period of five years and to modernize the yard. Thames Iron Works then would build three battleships, three cruisers, and institute a modernization program on older warships. Thames Iron Works insisted that all material should be imported duty-free from Britain; however, the Sultan refused the deal.

${ }^{10}$ F.O. 1552, Russia, Sir N. O'Connor to Count Mouravieff, St. Petersburg, 12 February 1898. Found in G.P. Gooch and Harold Temperly, eds., British Documents on the Origins of the War, 1898-1914, Vol. I (London: His Majesty's Stationery Office, 1927), 12-13. 
The Krupp Works provided field artillery for the Ottoman army and naval guns for the Dardanelles and Bosporus, submitted an offer on the commission plans. This offer was leaked to Krupp's British competitor, Armstrongs of Elswick, who bid two million lira below Krupp. Germany's Kaiser Wilhelm II succeeded in convincing Krupp to rebid the contract, however German complaints of bribery and corruption resulted in the Sultan replacing the naval minister and a modified program with new bids. The modified program consisted of two battleships, two protected cruisers, two armored cruisers, and two light cruisers. The program was considered by Krupp as unrealistic and the company refused to submit new bids,subsequently, the British shipbuilder Armstrongs received the first order in January 1898 for a cruiser, the Hamidiye, and two large torpedo boats. Armstrongs assumed and settled all English compensation claims." The Krupp Works did receive a contract to rebuild seven warships on 11 August 1900. ${ }^{12}$ The arranged price was 648,000 gold lira. However, the ships did not arrive until May of 1901 because of Otttoman delays in paying for fuel in Genoa.

The Essen Armaments Company of Germany was a consortium that included Krupp Works, Germania Werft, Schichau, and Vulkan Werft. As a group, they were owed 648,000 gold lira by the Ottomans. Not included in this amount was the upkeep of sailors who manned the ships the consortium had contracted to rebuild. Funds for the upkeep of the crew during the shipyard period was non-existent. Intervention by

"Pears, 172.

${ }^{12}$ Güleryüz, 10. 
Germany's Kaiser went unheeded concerning the destitute sailors and by the summer of 1901, nearly thirteen months of non-action had reduced the crews to paupers. Instead of paying the salaries of the crews, the Sultan demanded that the consortium advance 6,000 gold lira in order to make one of the ships, the Izmir, ready for sea and to pay the salaries of the four Ottoman supervisors in the shipyard. The consortium now had to submit to this extortion because refusal to meet the Sultan's demands could endanger negotiations for a large contract for the Ottoman army. ${ }^{13}$ The Sultan now proposed that the consortium reduce the cost of reconstruction of the ironclad Asar-i Tevfik from 282,000 to 65,000 gold lira. This amount would not cover work already carried out. As consolation, Germania Werft received the contract to build two torpedo cruisers, the Peyk-i Sevket and the Berk-i Satvek along with an armament orders for field artillery and naval guns for the Dardanelles and the Bosporus. Krupp and the consortium conceded to the pressure. ${ }^{14}$

The Italian shipbuilder Ansaldo got involved in Ottoman fleet expansion in January 1900. Italy presented claims to the Sultan's government for Italian property destroyed during the uprising of 1895-96. The Sultan once again hoped to settle these claims by placing armament orders with various Italian firms. In October 1898 Ansaldo submitted a bid to rebuild the ironclad Mesudiye and other ships. The armaments were originally to be supplied by Krupp Works but Krupp did not desire to be part of any additional Ottoman fleet contracts, so Armstrongs guns were substituted. In January

${ }^{13}$ Ibid., 12.

${ }^{14}$ Ibid. 
1900 Ansaldo quoted a price of $\$ 2,332,800$ to refit the Mesudiye, the Muin-i Zafer, and the Feth-i Bülend. This price was not final, and further discussions led to reduced remuneration. Ansaldo assumed and settled all Italian compensation claims. ${ }^{15}$

The United States government also submitted claims for compensation for losses incurred by American citizens during the Armenian disturbances. Most of the American claims were for damages to missionary property. The claims ammounted to 22,000 gold lira. For five years, diplomatic relations between the United States and the Ottoman Empire revolved around the issue of the indemnity for damages. After the SpanishAmerican War of 1898 , a preliminary agreement to build a protected cruiser in the United States to offset the indemnity claims was reached yet the Sultan was still not fully prepared to cooperate. Final agreement was still not attained after two years of further negotiations and it would take a show of gunboat diplomacy in the form of the United State's battleship USS Kentucky (BB-6) sent to Istanbul in December 1900 to cause real movement on the cruiser contract. ${ }^{16}$ General Ahmet Pasha went to the United States to negotiate with the American government over this ship. Ahmet Pasha suggested the builder, William Cramp and Sons of Philadelphia, reduce the cost of the cruiser from 585,000 to 300,000 gold lira. Additionally, Cramp would pay the Ottoman government 100,000 gold lira in order to settle indemnity claims. The American government

ispears, 172.

"Leland J. Gordon, American Relations with Turkey, 1830-1930: An Economic Interpretation (Philadelphia: University of Pennsylvania Press, 1932), 236-241. See also Lloyd C. Griscom, Diplomatically Speaking (Boston: Little, Brown, 1940), 134. 
officially refused the suggestion but let it be known that indemnity claims would be waived if and when the contract was signed with Cramp. The contract was signed in December 1900 after the Kentucky visit. The final cost of the ship was 355,000 gold lira. ${ }^{17}$

French compensation claims had not progressed sufficiently to satisfy Paris, and French naval forces seized the island of Mitylene on 5 November 1901. The French occupied the island and approprite customs duties. The Sultan appealed to Germany's Kaiser for assistance but was advised to pay the claims. The Sultan made a down payment, but France had to resort to gunboat diplomacy again in 1905 to extract further payments. ${ }^{18}$ French shipbuilders did not engage in the intrigue that plagued the English and Germans over naval purchases. The French armament manufacturers concentrated on sales of artillery, equipment, and munitions for the Ottoman army. They provided items "off the shelf" instead of long-term as required in ship construction. The Ottoman government's practice of spreading military sales around did entice French shipbuilders Schneider-Crevsot to submit a successful bid to build four Sivrihisar-class torpedo boats. Further orders from Schneider-Crevsot resulted in the 200-ton Refahiye-class and the 420-ton Marmaris. The Marmaris design was based on an indigenous Ottoman warship class that had been successful in coastal duties and the overall size of the class of ships was compatble with the overhaul facilities available to the Ottomans. While negotiating

${ }^{17}$ Fred T. Jane, ed. Jane's Fighting Ships, 1910 (London: Sampson Low Marston, 1910), reprint New York: Arco Publishing Company, 1969), 421.

${ }^{18}$ Monroe, $51-52$. 
the torpedo boat proposals, the French shipbuilder Atelier de la Garonde convinced the Ottomans to purchase four destroyers. These were of the Durandal class were 280 tons and proved to be excellent at convoy and anti-submarine activities. Overall, they were among the better ship purchases negotiated by Istanbul. ${ }^{19}$

The English had been a fixture in Ottoman naval circles since the reign of Sultan Abdul Aziz, however, the naval advice received always favored English interests. The English technical advisors served the British first, the Ottomans second. The senior naval advisor's order of "advising" was to secure business for English yards, to protect English interests in the Empire, and finally to train Ottoman officers. Shortly after the Young Turk Revolution of 1908, Istanbul requested that London provide an admiral to reorganize the Ottoman Navy and oversee a proposed spending program of $\$ 76,000,000 .^{20}$ The British naval mission commander, Admiral Sir Douglas Gamble, arrived on 18 September 1908 . He started his mission by proposing that the overman and overage naval officer corps be reduced. This would leave a younger corps of Britishtrained officers. Attempts to downsize the naval officer corps met fierce resistance. A naval rank was considered to be no more than an additional source of income and promotion dependent on the benevolence of influential contacts. Gamble had by March 1909 succeeded in reducing the bloated officer corps but with a British naval

"Güleryüz, 12-13.

${ }^{20}$ Paul Halpern, The Mediterranean Naval Situation, 1908-1914 (Cambridge, MA: Harvard University Press, 1971), 314, and see T.A. Brassey, The Naval Annual 1909 (Portsmouth: J. Griffin and Co., 1909) 43. 
mission in operation in Greece, one must question Gamble's true motives in reducing the manpower of the Ottoman Navy on the eve of the Balkan War.

Sultan Abdul Hamid II was deposed on 26 April 1909 and was replaced by Sultan Mehmet V (1909-1918).21 The Committee of Union and Progress (C.U.P.), known in the West as the "Young Turks," gained in power, and serious reforms in both the political and military arenas were anticipated. Gamble arranged a naval maneuver for the benefit of the newly-elected parliamentarians. The training was not very realistic when compared with western fleets, but Gamble took the opportunity to address the parliamentarians on the need to modernize the fleet. The Admiral pointed out that flags, banners, and paint are no substitutes for new construction, but his plea had little chance of succeeding because Ottoman funds were not available. The C.U.P. did recognize the diplomatic value of a blue-water fleet when the cruiser Hamidiye participated in "show the flag" roles at Britain's coronation of King George $V$ in 1910 and the opening of the Panama Canal in $1914 .{ }^{22}$

From the beginning of 1910, Gamble clashed with Ottoman ministers regarding warship orders and finances. He proposed that all decisions in naval matters should be left to the Minister of Marine, Arif Halil Pasha, and himself, an arrangement that would have ended the influence of the Ottoman Foreign Office. Political rivalries within the bureaucracy of Ottoman government had become defined with a British naval advisor,

21Paneth, 73.

${ }^{22}$ New York Times, 30 March 1914. 
German army influence, and the French-inspired C.U.P.

Admiral Gamble prepared a program of new construction which was to include two capital ships, three cruisers, and ten destroyers. The Porte wanted the battleships first, and the Minister of Marine used this program during secret negotiations with the British shipbuilder Armstrongs. The agreed upon amount for the two capital ships, five million gold lira, was far beyond the treasury's means. When the government learned of the unauthorized dealings, Ferik Halil was replaced as minister of marine by Sadrazam Hakki Pasha.

Gamble found the position difficult, and the strain began to extract a toll on the admiral. He noted the job of reorganizing the Ottoman fleet ". . an awful task and a thankless one. I mean one never sees any radical change or improvement -- and it requires a man in strong health and full vigour to stand the disappointment and continued grind .... They are talking very big about a programme of construction, and the engagement of the officers I want, but nothing practical has been done and until the actual steps have been taken, I cannot believe in any of their promises or assurances. ${ }^{123}$ Discouraged and ill, Gamble submitted his resignation in February 1910 but not before he advised the Porte to acquire small ships initally in order to facilitate training for younger officers.

Gamble was succeeded as naval mission chief by Admiral H.P. Williams. Albay Mahmut Muhtar, the Ottoman Minister of Marine, refused to work with the British and

${ }^{23}$ Quote found in Halpern, The Mediterranean Naval Situation, 315. 
disliked cooperation in any sort. The Minister's deep distrust of the British mission lay in his annoyance that the work of modernizing the Empire's defenses lay in the hands of foreigners. The commander of Ottoman army forces was General von der Goltz of the German mission and Admiral Williams commanded the fleet. The Italian-Ottoman War of 1911-12 and the First Balkan War of 1912-13 witnessed a German-trained army routed, a British-trained and- equipped fleet impotent, and Istanbul saved by Russia when it put the brakes on Bulgarian drives on the Dardanelles. For Russia would not allow any power other than the Ottoman Empire to control the straits. ${ }^{24}$

The role of the Dardanelles Straits cannot be underestimated. The only passage out of the Black Sea had been a blessing and a curse for the Ottomans. Control of the Straits basically meant control of the Black Sea. For nations that relied on Black Sea ports to import/export, the straits were a commercial jugular vein. Concern for free navigation led to the Straits Convention of 13 July 1841 in which Austria, France, Great Britian and Russia affirmed Ottoman control. Istanbul's control was reaffirmed by the Treaties of 1856 and $18711^{25}$

The Italian-Ottoman War forced the closing of the Bosporus Straits in April 1912, which adversely affected Russian commercial interests in the Black Sea and brought

${ }^{24}$ James T. Shotwell and Francis Deak, Turkey at the Straits (New York: The MacMillan Company, 1940), 90-94.

${ }^{25}$ Barbara Jelavich, The Ottoman Empire, the Great Powers, and the Straits Question, 1870-1887 (New York: The MacMillan Company, 1971), 20-23. Also, see Charles G. Fenwick, International Law (New York: Appleton-Century-Crofts, Inc., 1948), 396. 
renewed Russian concern over the balance of power in the region. The Russian Ministry of War assumed that the Ottomans would cooperate closely with Austria and Germany should a general war break out in Europe. The Russians did not fear the Ottoman army because roads into the Caucasus mountains were neglected and railroads were too scarce to allow quick mobilization against Russia. It was Ottoman naval power that the Russians were feared. Russia had been powerless to prevent the Ottomans from closing the straits to neutral commerce during the Italian conflict. This halt in commercial shipping reminded Russia of it's own vulerablity to economic strangulation. Russia received three-fourths of her imports through Black Sea ports. Ottoman naval modernization raised serious questions about the security of Russia's own Black Sea coast.

In a Black Sea naval arms race, Russia was at a distinct disadvantage. The Ottomans could purchase battleships abroad and acquire a fleet quickly. International treaty on the closure of the Dardanelles to warships prevented Russia from adding to the Black sea fleet except through local shipyard production. Russian Foreign Ministry officials concluded that if Russia took no effective countermeasures, the Ottomans would possess naval supremacy in the Black Sea by 1916. In the opinion of the Russian Naval General Staff, that would constitute a "serious threat to the integrity of the Empire."26 In 1912 these concerns produced for the Black Sea fleet a naval construction program consisting of three battleships, nine destroyers, and six submarines, all to be completed

${ }^{26}$ William C. Fuller, The Quest for Exits (New York: The Free Press, 1992), 436. 
by 1918 . This program would cost $\$ 52,668,933 .{ }^{27}$ After World War I started, to ensure that the Bosporus Straits remained open and free to Russian shipping, Russia demanded, on 4 March 1915 that the allies consent to the Russian annexation of Istanbul, all of Thrace, and the Sea of Marmara, along with numerous islands. Under pressure of war conditions and of the need to keep Russia in line, England and France had to acquiesce. ${ }^{28}$

The desire to control waterways in the Sultan's domain was a British goal also. The route to India and the Far East passed through the Suez Canal, an Ottoman waterway. A substantial portion of Britain's food imports, including five-sixths of the barley and one-half of the oats, originated in Russia and passed through the Straits. By 1911, the Black Sea accounted for one-third of Britain's food imports and, when added to the portion transiting the Suez Canal, nearly half of Britain's food supply passed through Ottoman waters. ${ }^{29}$

The naval balance in the Aegean Sea area has traditionally been unstable. The equilibrium dissolved when Greece acquired the cruiser Georgios Averoff (Averoff) in 1910. The purchase from Italy of such an offensive platform forced Istanbul to acquire some sort of balancing force. Ottoman naval purchases prior to the Greek acquisition of the Averoff were directed at coastal defense along with confronting Russian warship construction. The treasury on hand at the begimning of the Twentieth Century could

${ }^{27}$ Ibid., 437-438.

${ }^{28}$ Shotwell, 100-101.

${ }^{29}$ "Strategy and Food Supplies: The Mediterranean Route," The Times (London), 4 June 1912. 
afford to counter only one serious threat. Russia was barred from injecting warships into the Black Sea and had to rely on local construction with limited facilities available at Sebastopol and Novorossisk. This restriction permitted for Ottoman naval acquisition at a somewhat leisurely pace. With Greece having such a large cruiser, along with Russian ship construction accelerating, the Ottoman Empire was faced with two hostile neighbors arming at breakneck speed.

Adding to Ottoman naval concerns was the British assistance given to the Greek navy during the period prior to the First Balkan War of 1912-13. The British naval mission in Greece began in 1911, and it was more active than the British mission to the Ottoman navy. The role of the British was not restricted to advising as with the Ottomans. Destroyer tactics used so successfully against the Ottomans were a direct result of the British Commander Hubert Cardale. The sucessfull Greek blockade of the Dardanelles can be attributed to the British Commander Hugh Watson, who refitted many ships during the conflict to maintain the pressure. The Balkan War of 1912-13 witnessed the Greek and Ottoman fleets both with British influence and direction, locked in combat. Greek intradition in the Dardanelles prevented Ottoman reinforcements from reaching the battlefield and resulting in the shaughter of muslim civilians $^{30}$

Ottoman fear that the Greeks could force the Dardanelles led the Porte to order eight twelve-inch coastal howitzers from Krupp and to a request a retired German naval

${ }^{30}$ D.J. Cassavetti, Hellas and the Balkan Wars (London: T. Fisher Unwin, 1914), 26-31. 
officer to advise in the operation of such weapons. The German Vice-Admiral Wilhelm Schack, who had a reputation as an expert in coastal fortifications, was sent down to Istanbul. Since the presence of a German expert in defensive emplacements would have risked a British protest, Admiral Shack remained incognito. ${ }^{31}$ Ottoman desire for naval supremacy in the Aegean Sea was driven by fear of Greek and Bulgarian genocide of Turkish Muslims, not by imperialism. Past conflicts had shown that when the power of the Sultan was absent, slaughter of Muslims by Greeks, Bulgarians, or Russians was not only possible but probable. The loss of strategic islands to Greeks in preceding conflicts removed early warning stations resulting in the entire coast of Anatolia open to naval attack. The loss of power in the peripheries could lead to the slaughter of Turks in Anatolia proper unless the balance of naval power in the Aegean was restored.

The Ottoman naval assets in Mesopotamia prior to 1914 consisted of the gunboat Marmaris, smaller gunboats the Dogan, the Selmanpak, and the Tarantula, and some minor police motor boats: an adequate force to police the north end of the Persian Gulf. The military presence was not sufficient to enforce Istanbul's sovereignty and on 23 January 1899 , the Sheikh of Kuwait agreed not to cede territory or receive foreign representatives without England's sanction. In return, the Sheikh received 15,000 rupees and in order to enforce the agreement, the government of India was authorized to prevent by force any attempt on the part of Istanbul to enforce governmental control. In 1901, a quarrel between the Sheikh of Kuwait and the Amir of Nejd (now Saudi Arabia) resulted

${ }^{3}$ Report by Austrian military attaché, Istanbul, 27 May 1914, cited in Halpern, The Mediterranean Naval Situation, 353. 
in conflict, and when Istanbul dispatched troops to quell the fighting, England warned the Porte that the British government would prevent Ottoman forces from removing the Sheikh of Kuwait. A protectorate was not established over Kuwait, and both England and Germany considered Kuwait part of the Sultan's dominions but Istanbul considered English interference as aggression. ${ }^{32}$

Principal naval bases for Ottoman naval forces in 1914 were Alexandretta, Basrah, Canakkale, Beyrut, Djeddah, Hodieda, Jaffa, Samsoun, Izmir, Sinope, Smyrna, Trebizond, and the main arsenal at Istanbul. ${ }^{33}$ The mercantile marine, or civilian vessels capable of being requisitioned for military use numbered 143 steamers of 69,333 tons net and 900 sailing craft of 180,000 tons net. ${ }^{34}$ With inadequate ground infrastructure, bulk movement of any commodity was in most part waterborne. The main Ottoman coal port was Zonguldak, roughly 150 miles from the Bosporus Strait on the Black Sea. Small sailing craft in most regions of the Empire were sufficient for local needs. For large bulk import/export, foreign- flagged bottoms dominated the market.

The Ottoman navy did have a marine unit of about 4,000 men. The author speculates that the marines were incorporated into regular army units in addition to the traditional roles assigned to marine units: shipboard security, pier sentry, and base and

${ }^{32}$ Gooch, Vol. 1, 333-334.

${ }^{33}$ O.J. Parks and Maurice Prendergast, eds., Jane's All the World's Fighting Ships 1919 (London: Sampson Low Marston, 1919; reprint, New York: Arco Publishing Company, 1969), 587.

${ }^{34}$ Fred T. Jane, ed. All the World's Fighting Ships 1914 (London: Sampson Low Marston, 1915), 409. 
shipyard protection.

A comparison of the naval forces confronting the Ottoman Empire prior to 1914 is found in Table 1. When comparing Ottoman and Greek naval assets, the Ottomans' position was not critical so long as the Ottoman navy went on the defensive, utilized the larger Ottoman army in planning, and, finally, avoided any confrontation in the Black Sea. Comparison of Russian and Ottoman naval assets clearly shows that the Ottoman forces were inferior. Compounding the situation, the Russians possessed submarines and destroyers to control the communations sea lanes, logistics corridors, and overall battlespace.Compounding the problem in the Black Sea, the Russians possessed land forces adequate to seize and control battlespace in Anatolia proper. Unlike Greece and Bulgaria, Russia had resources to provide follow-on forces needed to legitimize claims to geographic gains.

Russian naval plans were more ambitious. In April 1911 Russian Vice Admiral Ivan K. Grigorovitch, Russian Minister of Marine, laid down a naval budget construction plan calling for a Black Sea fleet one and one-half times the combined forces of Bulgaria, Romania, and the Ottoman Empire. Admiral Grigorovitch did not intially acquire the funding for the Black Seat fleet buildup. The Russian Duma did fund Baltic Sea fleet construction in June 1912, opting to forestall Black Sea costs in order to prepare for possible Baltic action. Wr, with the Ottoman fleet on the verge of acquiring the two modem dreadnoughts from England, the Duma in April 1914 finally approved the funds for an accelerated Black Sea construction program. These ships, along with the smaller complementary naval forces needed to support fleet operations, doomed any Ottoman 
TABLE 1

NAVAL FORCES CONFRONTING THE OTTOMAN EMPIRE, 1914

\section{Type of Ship}

Pre-dreadnought

Coast-defense ship

Armored cruisers

Protected cruisers

Destroyers

Torpedo boats

Submarines

\section{Greece Ottomans}

2

3

1

1

14

17

2

2
1
NA
2
8
9
2

\section{Russia}

3
6
1
2
26
14
NA

Source: Fred T. Jane, ed., All the World's Fighting Ships 1914 (London: Sampson Low Marston, 1915: reprint, New York: Arco Publishing Company, 1969), 441, 411, 409.

hopes of parity with the Russian Black Sea Fleet.

Another area of concern for was the rail line from Germany to the Ottoman Empire. This line had to bring all the large munitions ( $5 "$ and larger) down from Germany. Ottoman munition works could not produce large- caliber munitions or the assorted specialty ordinance (gas, phosphorus, light, shrapnel) needed to supply a modern army and navy. The rail line ran through Serbia and Bulgaria. So either country could halt shipments of logistics. The shortage of large caliber munitions would plague the Ottoman navy and prevent the full utilization of the battleships in both the Balkan Wars and World War I. ${ }^{35}$

${ }^{35}$ Guleryüz, 20, 33. 
Ottoman enlisted personnel did not have the excellent reputation the Ottoman foot soldiers enjoyed. The British press durning World War I expressed a dismell view of ethnic Turks and the sea writing: "Since the days when the Ottomans emerged from the back of beyond in Asia Minor in 1453, down through the time of Suleiman the Magnificent -- when Turkey was at her apogee -- to the present day the Turk has been a useless person at sea." ${ }^{136}$ The reasons are less directed toward the enlisted ranks than the officer corps. With multiple sources for Ottoman naval hardware, becoming proficient would be difficult but given the correct training, Ottoman sailors proved to be as enthusiastic and willing to tackle any task ordered, equaling the reputation of their ground forces. $^{37}$

The Ottoman navy entered the Twentieth Century lagging behind comparable navies. They would spend a considerable sum of money trying to keep pace in a naval arms race Istanbul could not afford. The Sultan's Empire was vast and exploitable by more industrialized countries. European nations wishing to become empires quickly needed regions relatively developed in order to recoup expenses incurred in seizing them. Vast regions in Africa had been claimed by France and Great Britain while undeveloped areas claimed by Germany, Belgium, and Portugal. Any territory unseized by Europeans was fair game if local authority could be overcome. In the case of Abyssinia, local authority had been successful in preventing colonization. But the Sultan's regions were

${ }^{36}$ The Times History of the War, Vol. II (London: The Times, 1915), 22.

${ }^{37}$ Ibid., 39. 
vulnerable to seizure under the right circumstances, and not just in Africa. European penetration of the peripheries of the Ottoman Empire had been ongoing. Distant regions such as Yemen, Sudan, Algeria, Tunis, and Kuwait, along with not so distant regions such as Egypt and Lebanon, had fallen under European influence. The main task of the Porte would be to prevent dismemberment of an Empire surrounded by states and nationalities bent on doing just that.

The Ottomans used naval programs drawn up by the British mission along with British tactics to utilize such plans. The frenzy of shipbuilding indicative of the early Twentieth Century drove naval plans to include large capital ships. The ownership and use of capital ships was the driving force behind empire building. It would be these very programs that would hobble Ottoman naval forces. The Ottoman ministers responsible for naval matters did not seem to realize that the programs the British naval mission proposed were influenced by both Alfred Mahan's view on empire building and British experience in empire seizing. In neither scenario is the true problem of the Ottoman Empire confronted: that of empire protecting. The Ottomans were not into empire building or seizing but holding onto what was theirs, not antagonize the mainly Christian states that the Ottoman Empire bordered. 


\section{CHAPTER II \\ ITALO/OTTOMAN WAR SEPTEMBER 1912 TO OCTOBER 1913}

In the early Nineteenth Century, the Ottoman Empire in Africa included Algeria, Tunis, Tripolitania, Cyrenaica, Egypt, Sudan, Eritrea, and the northern African desert area of Fezzan. European imperialist expansion began in earnest when Algeria was seized in 1834 by the French, and by 1881 Tunisia had become a French protectorate. Egypt became a vassal state of England in 1882, followed by Sudan in 1898. Eritrea and Somaliland fell in 1889 to the Italians. At the same time, French forces began to exert control upon the Saharan Desert region of Fezzan.

The loss of the peripheries, which under the best of times were under nominal Ottoman control, drained the treasury and injured the pride of the Ottomans. The Sultan, being protector of the Islamic faith, witnessed Christian forces with superior naval assets conquering Muslim territory at will. The Ottomans, having no control of the sea lanes or forces capable of injecting troops to block European landings, became passive spectators to the dismemberment of their own empire. By the early Twentieth Century, the only territories left in northern African under direct Ottoman control were the provinces of Tripolitania and Cyrenaica, along with the desert region of Fezzan.

Italy became unified on 18 February 1861 and was therefore late in the colonial empire- building era. Eritrea and Somaliland became Italian colonies when the Ottomans 
were too weak to confront Rome after fighting Greece over Crete in $1897 .^{38}$ Rome had for centuries behaved as if the northern coast of Africa were a legitimate sphere of influence, the area in question being Tunisia, Cyrenaica and Tripolitania, see Appendix 2. French ambitions for North Africa began with Napoleon's Egyptian endeavor in the late Eighteenth Century and led to the seizure of Algeria in 1832. The occupation and proclamation of a protectorate over Tunis in 1881 alarmed Rome and ultimately brought Italy into the Triple Alliance with Austria and Germany on 20 May $1882 .{ }^{39}$

French Foreign Minister Freycinent reassured Italian Foreign Minister Francesco Crispi that France had no intentions of occupying Tunis. France landed troops in 1881 under the guise of a protectorate. When Italian concerns were voiced, Freycinent stated, "The Mediterranean ought to belong to France and Italy." ${ }^{40}$ Freycinent hinted that since France had stolen Tunis, Italy therefore had a "right" to steal Tripolitania. The method of flirting with one country in order to extort concessions from another is part of the regular mechanism of diplomacy and is made palatable by the fact that alliances rest exclusively on self-interest.

The integrity of the Ottoman Empire had been "guaranteed" by the European Powers both in the Treat of Paris in 1856 and in that of Berlin in 1878 but by 1900 the distant possessions of the Ottoman Empire were under Christian European "protection."

${ }^{38}$ Güleryüz, 8-9.

${ }^{39}$ Dr. Alfred Francis Pribram, The Secret Treaties of Austria-Hungary, 1879-1914, Vol. II (London: Oxford University Press, 1920), 65-69; and Lowes Dickinson, The International Anarchy, 1900-1914 (New York: The Century Co., 1926), 86-89.

"Dickinson, 86. 
Rome feared France would seize Tripolitania from bases in Algeria and Tunis. The Italian government, not wishing to be viewed as violating the integrity of the Ottoman Empire,regardless of Eritrea and Somaliland, desired only the continuation of the status quo. In the Triple Alliance treaty negotiations, Italy received assurances that if France moved into Tripolitania, Germany would aid Italy if war resulted. The third article runs as follows:"If it were to happen that France should make a move to extend her occupation or even her protectorate or her sovereignty, under any form whatsoever, in the North African territories, whether of the Vilayet of Tripoli or of the Moroccan Empire, and that, in consequence thereof, Italy, in order to safeguard her position in the Mediterranean, should feel that she must undertake action in said North African territories, or even have recourse to extreme measures in French territory in Europe, the state of war which would thereby ensue between Italy and France would constitute, ipso factor, on the demand of Italy and at the common charge of the two allies, the casus foederis with all the effects..." ${ }^{141}$ Crispi feared encirclement of the western Mediterranean if France were to extend complete annexation of Tunis, as in the case of Algeria. With this concern, Italy received assurances in the renewed Triple Alliance Treaty of 1891 that the status quo would be maintained in Tunis.

Italy's King Humbert I (1878-1900) pressed colonial expansion by use of the military whenever the opportunity presented itself. Humbert sought commercial concessions from China and Morocco and territory on the Horn of Africa from local

${ }^{41}$ Ibid., 89 . 
tribesmen. Humbert's colonial expansion was not limited to Ottoman territory. The friendship agreement between Italy and Abyssinia, the Treaty of Ucciali, signed in 1889 , was denounced in May 1893 by Abyssinia's Emperor Menelik (1844-1913). Language differences led Italy to believe a protectorate existed over Abyssinia, a view Russia accepted and France rejected. ${ }^{42}$ A subsequent war erupted between Italy and Abyssinia in 1895 that led to an Italian defeat at Amda Alagi in December 1896. London rejected Italian requests to land troops at Zeila in British Somalia resulting in an Italian defeat. The French, working out of French Somaliland, supplied Menelik with money, weapons, and officers. ${ }^{43}$ However, Italy still held out a desire to maintain Abyssinia as a sphere of influence with English help. ${ }^{44}$

The Triple Alliance Treaty did not include French mischief in Italian colonial affairs. Italy's membership in the Triple Alliance encouraged French antagonism and Crispi realized for Italy to succeed in colonial regions, some sort of accommodation with France and possibly England would have to be achieved over the objections of King Humbert. Humbert's anti-French sentiments originated in the loss of Nice and Savoy to France in 1860. Humbert's assassination at Monza in 1900 elevated Victor Emmanuel III (1900-1945) to the throne and would signal the beginnings of a rapprochement with France.

${ }^{42}$ Luigi Albertini, Origins of the War of 1914 (London: Oxford University Press, 1952), 79-80.

${ }^{43}$ Ibid., 80 .

${ }^{4}$ F.O. Abyssinia 48, No. 184, Sir R. Rodd to the Marquess of Landsdown, Rome, 6 September 1903. In Gooch, Vol. I, 315-317. 
The new Italian Prime Minister, Rudini, began secret negotiations with France in December 1900. Rudini received assurances that if France injected itself into Morocco, then Italy would reserve the "right" to herself as a measure of reciprocity to develop influence in Tripolitania-Cyrenaica. ${ }^{45}$ France would get free reign in Morocco and Italy in return would get Tripolitania. Paris agreed to respect Italian ambitions in Tripoli in the hope of detaching Rome from the Triple Alliance ${ }^{46}$

In order to neutralize French covert operations against Italian political and colonial spheres, Italy's foreign minister Prinetti and French foreign minister Barrere began clandestine meetings on 4 December $1900 .{ }^{47}$ The final agreement defined the respective zones of expansion of the two countries in North Africa, interpreting their respective positions in regard to military alliances and guaranteeing their reciprocal neutrality in a war not provoked by them. The agreement not only cleared up boundary disputes in Tunis, but also removed the threat that France might be attacked by Italy's coming to Germany's aid. Victor Emmanuel refused to sign the document because of the renewal negotiations of the Triple Alliance Treaty, instead dating the agreement 10-11 July $19024^{48}$ The secrecy of the agreement leaked out after Victor Emmanuel visited Paris on 14-18 October 1902 and London on November 14-21 1902. German Major von

${ }^{45}$ Pribram, 244.

${ }^{46}$ F.O. Italy, 836, No. 62, Lord Currie to the Marquess of Landsdowne, Rome, 14 April 1901. In Gooch, Vol. I, 283.

${ }^{47}$ Albertini, 129.

«8 Ibid., 131. 
Chelius, military attaché in Rome, questioned Italian General Saletta about the rumored Italian-Franco agreement and received the statement, "We are obliged to maintain good relations with France and England on account of the Mediterranean, where lies our vital interest. ${ }^{149}$

Italian relations with England had been good since unification in 1861 but the Fashoda Crisis in the Sudan hinterland caused concern in Rome. French claims to the Nile Valley in and around the headwaters of the White Nile led to the Anglo-French Agreement of 21 March 1899. London and Paris agreed to exclude France from the Nile basin. In return, France retained the right to expand in West Africa towards the Sahara and the interior. The agreement infringed upon an Italian-English agreement signed on 24 March 1899 in which Italy agreed not to encroach within 150 kilometers of the Nile. During the Fashoda Crisis, Italian foreign minister Admiral Canevaro, on 26 October 1898, assured the English ambassador that Italy could only remain neutral or side with England. ${ }^{50}$ Canevaro could not convince the English that Italy should occupy Tripolitania immediately. Canevaro was successful in getting England to forgo any claim on territory or political influence north of the southern extremity of the Fezzan. ${ }^{51}$ This left an area 150 kilometers from the Nile River west to the Tunis border open for Italian conquest.

${ }^{49}$ Major von Chelius, to General von Schlieffen, 1 December 1903, found in E.T.S. Dugdale, German Diplomatic Documents, 1871-1914, Vol. III (London: Harper \& Brothers, 1931), 168-169.

${ }^{50}$ Albertini, 104.

${ }^{51 F}$.O. Italy, 797, No. 74, Lord Currie to the Marquess of Salisbury, Rome, 10 April 1899. In Gooch, Vol. I, 204. 
Further French territorial advancement in the Sahara south of Tripolitania, Cyrenaica, and Fizzan occurred in February 1910. French colonial forces defeated the Sultan of Wadai and occupied an area from the Egyptian-Sudan border west to Lake Chad and north to the southern extremities of Fezzan. This occupation of the last unclaimed area of North Africa gravely concerned the Great Powers. Even though Italy had acquired agreements with England, France, and Spain in addition to commitments from Germany and Austria, another power might still seize the Vilajet given the proper circumstances. $^{52}$

Italy had by agreement secured the right to go into Tripolitania by ignoring French imperialism in Morocco and by treaty with Germany and Austria. In order to avoid antagonizing Russia, Italian prime minister Racconigi worded an agreement in which Rome agreed to respect Russian views on the Straits. St. Petersburg agreed to support Rome concerning Italian interest in Tripoli and Cyrenaica. With the conclusion of the Racconigi agreement, Italy had secured Russian, French,German and Austrian consent to act in Tripolitania.

Sir Ernest Grey, the English Foreign Secretary, was disinterested in Italy's desire to acquire Tripolitania. Grey wanted to detach Italy from the Triple Alliance because Italian naval power was a force to be reckoned with in the Mediterranean. English involvement in Italy is clearly visible in the growth of the Italian naval complex. Count

${ }^{52}$ F.O. 5704/5704/10/22, No. 20, Rodd to Grey, Rome, 15 February 1910. G.P. Gooch and Harold Temperley, British Documents on the Origins of the War, 1898-1914, Vol. IX, Part I (London: His Majesty's Stationary Office, 1933), 262. 
Cavour, the Italian naval minister, and his protege, Benedetto Brin, encouraged government and private shipyard expansion via naval expansion and warship exports. English industrialists correctly predicted Italian protectionist sentiments and engaged in joint ventures such as the Vickers-Terni Works at Spezia, the Armstrongs gun factory at Pozzuoli, and the Peterson works at Naples. Military industrial enterprises which also included English backers were the Ansaldo Company works at Genoa and the Odero and Orlando factories at Leghorn.

The fiasco in Abyssinia was caused in part by English refusal to allow Italian troops to land at Zeila. Italy could not force a landing due to political liabilities and the inferior Italian navy. In order to avoid a repeat, Italy embarked upon a naval construction program which in ten years produced the strongest Mediterranean based fleet. Table 2 shows the growth of the Italian fleet from 1900 to 1910.

In July 1908, the Italian navy was in essence an English fleet crewed by Italians. The English owned a share of the naval yards, the English inspired naval engineering, and by 1910 all Italian naval guns were Elswick, as on English ships. Torpedo technology was exclusive English Whitehead 18-, 15- and 14-inch. ${ }^{53}$ Engineering advancement followed the English Parson steam turbines and incorporated oil, coal, and mixed-fuel stoking. Alternate- fuel power plants allowed for global use of ships, ideal for an English Empire circling the world or Italian aspirations for such.

"35red T. Jane, ed., All the World's Fighting Ships 1906/07 (London: Sampson Low Marston, 1907; reprint, New York: Arco Publishing Company, 1969), 290. 
TABLE 2

GROWTH OF THE ITALIAN FLEET, 1900-1910

Type of Ship

Battleships

Cruisers

Destroyers

Torpedo Boats

Coastal Defense $1900^{\mathrm{n}}$

6

19

6

17

4
$1906 / 07^{\circ}$

6

19

27

89

6 $1910^{\circ}$

12

19

40

90

10

"Fred T. Jane, ed., All the World's Fighting Ships 1898/99 (London: Sampson Low Marston, 1899; reprint, New York: Arco Publishing Company, 1969), 131.

'Fred T. Jane, ed., All the World's Fighting Ships 1906/07 (London: Sampson Low Marston, 1907; reprint, New York: Arco Publishing Company, 1969), 285.

'Fred T. Jane, ed. All the World's Fighting Ships 1914 (London: Sampson Low Marston, 1915; reprint, New York: Arco Publishing Company, 1969), 286-299.

Writing in 1909, the British naval constructor, Sir W.H. White, concluded with this statement about the Italian-English naval relationship:"The traditional friendship between Italy and Great Britain, and the important influence which the existence of a powerful Italian fleet must exercise upon the maintenance of our position in the Mediterranean, make it a matter of the highest importance that Italy should not decline from her position relatively to other Mediterranean powers, or lose the place that has been so hardly and honourably earned amongst the war-fleets of the world. ${ }^{154}$

${ }^{54}$ Archibald Hurd, Italian Sea-Power and the Great War (London: Constable and Company Ltd., 1918), 122. 
The first decade of the twentieth century witnessed a political firestorm in the Mediterranean area. Morocco was occupied by a French mission in January 1905 , ostensibly to impose a program of reforms on Sultan Abdul Aziz IV (1894-1908). ${ }^{55}$ Germany had sizeable economic programs in Morocco and had hoped to ensnare the country into Berlin's sphere of influence, however France controlled the police and thus was in a position to enforce whatever Paris decided. Greeks on Crete stepped up agitation for unification with Athens in 1908, spurred on by Eleutheros Venizeles, the future Greek prime minister. The Young Turks movement, seeking to save the Ottoman Empire, started on 6 July 1908 and would conclude with the ascension of the C.U.P. to power. The Committee of Union and Progress weathered a counter-coup and forced Abdul Hamid out. Abdul Hamid was be replaced with his brother, Mehmet who fulfilled the role of the quintessential constitutional monarch.

With the restoration of the Ottoman Constitution of 1876, the Great Powers suspended, then gave up on, demands for reform throughout the empire. With renewed spirit sweeping the Ottoman Empire and fear that the C.U.P. might not be as vacillating as Abdul Hamid, Austria moved to annex Bosnia-Herzegovina on 6 October 1908. Austria also encouraged Prince Ferdinand of Bulgaria to proclaim independence. The Bulgarian autonomous principality under Prince Ferdinand took advantage of uncertainty in Istanbul and declared independence on 5 October 1908. Both moves were violations of the Treaty of Berlin, though Istanbul considered Bosnia-Herzegovina a lost cause,

sprince Bernard von Bülow, Memoirs, Vol. II (London: Oxford Press, 1931), 104-106. 
however, Bulgaria had benefited from costly internal improvements. Bulgaria in 1878 had only a single line of railway 137 miles long; in 1911, more than 1200 miles of line were placed in operation. The gross national product had doubled from 1878, and the prospect of additional economic growth was excellent. ${ }^{56}$ The Ottomans had invested heavily in Bulgaria in order to placate Christian European Powers. Prince Said Halem Pasha, the new Grand Vizier, feared both for the majority Muslim population and the threat posed by an aggressive Slavic state. ${ }^{57}$

The Young Turks leadership protested the annexation of Bosnia-Herzegovina with an economic boycott of Austria-Hungary commerce. Starting in Salonika, the boycott spread throughout the empire. The use of economic pressure to effect political outcomes alarmed the great industrial powers, which considered the Ottoman Empire an excellent market for finished goods. ${ }^{58}$ Italian interests were especially vulnerable to boycotts. Maintaining the status quo in regard to Tripolitania and Cyrenaica had been the foreign policy of Italy up to 1911. Prior agreements with other powers left the fate of the Vilajet up to Rome, and as long as no other power converted the Vilajet, Italy was content to exploit but not own.

The political situation changed in Italy when Giovanni Giolitti regained power in 1911. An earnest nationalist, Giolitti used whatever means necessary to achieve political

${ }^{56}$ Carlton J. H. Hayes, A Political and Social History of Modern Europe, Vol. II (New York: The Macmillan Company, 1925), 521-522.

${ }^{57}$ Albertini, 216-219, 214.

${ }^{58}$ F.O. 1496/250/11/44, No. 191, Rodd to Grey, 31 December 1910. In Gooch, Vol. IX, Part 1, 263. 
results. Corruption was standard practice, and personal fortune Giolitti's goal. ${ }^{59}$ Giolitti was prominent in the Italian government in the 1880-90s and advocated colonial expansion into Abyssinia and Somaliland. Benito Mussolini opposed Giolitti and was arrested and sentenced to five years in prison for inciting resistance among the proletariat. The quasi-martyrdom propelled Mussolini to the forefront of Italian politics. ${ }^{60}$ After World War I, Giolitti would first confront, then mentor Benito Mussolini. It would be Mussolini who would subdue Abyssinia and Libya, fulfilling Giolitti's ambition for Italian colonial expansion.

Giolitti had to justify any aggressive action in regard to Tripolitania and Cyrenaica. G. Lowes Dickinson quotes Giolitti in explaining the reasons for seizing Tripolitania and Cyrenaica as "Western Africa from Tunis to Morocco was under the protection of European administration, Libya was very much behind the times. Slave markets were still held in Bengasi, and men and women taken by violence in Central Africa were sold in those markets: infamies which it was impossible to tolerate at the very gates of Europe. ${ }^{161}$ Other considerations needed to be protected were economic. The Banco di Roma had been quietly engaged in peaceful penetration of the two territories in order to monopolize commercial dealings, however, the Young Turks government had refused to grant Italy the same economic capitulation agreements

${ }^{59}$ Giovanni Giolitti, Memoirs of My Life, trans. by Edward Storer (London: Oxford Press, 1923), passim.

${ }^{60}$ Herman Finer, Mussolini's Italy (Hamden, CT: Archon Books, 1935), 54.

${ }^{6}$ Dickinson, 220. 
England and France enjoyed.

Capitulations were in place since the sixteenth century and allowed for foreign commerce while adhering to Islamic laws. Istanbul took the official position that the capitulations were privileges granted unilaterally by the Porte to the several powers for its own convience and could, therfore, be altered at any time by the government. Italy had no such claims to enjoy such capitulations, and since Ottoman finances had suffered because of the capitulations, allowing Rome to enjoy such was not in Istanbul's the best interest. The Ottomans had been forced to allow Italy some latitude in Tripolitania, but Italy desired an agreement to erect postal services in Anatolia and Istanbul refused to concede such a franchise. Italy furthermore demanded commercial monopolies for harbor construction at Tripoli. The Ottoman General Ibrahim Pasha, Vali of Tripolitania, refused to acquiesce. He knew fully of Italy's agreements concerning Tripolitania and became such a hindrance to Italian expansionism that he was recalled by Istanbul in August 1911 in the hopes of improving relations. ${ }^{62}$

The strained relations that Italy experienced with the Young Turks government was not the only reason Giolitti pressed for action. Istanbul was occupied with a revolt in Yemen inspired by British interests in Aden. The Grand Shirife in Yemen had never submitted to Ottoman authority, and the Young Turks' nationalist views benefitted English colonial expansion by agitating some non-Turkish ethnic groups in Arabia. ${ }^{6.3}$

${ }^{62}$ F.O. 33825/30691/11/44, No. 125, Rodd to Grey, Rome, 17 August 1911. In Gooch, Vol. IX, Part I, 266.

${ }^{63}$ Letter to Sir A. Nicolson from Sir F. Bertie, 14 May 1911, in G.P. Gooch, and Harold Temperley, British Documents on the Origins of the War, 1898-1914, Vol. VII 
Compounding the situation, revolts in Albania, Macedonia, and Armenia drained resources to such an extent that the Ottoman Empire was vulnerable in the peripheries. Giolitti also put forward that a real danger existed that Germany or some other power was on the verge of securing occupation of Tripoli and, if such happened, Italy would lose the chance to occupy the Vilajet forever. ${ }^{64}$ Thomas Nelson Page, the Unitef States ambassador to Italy, echoed that Germany had been bested in Morocco and the Kaiser still wanted to establish a Mediterranean beachhead. France controlled Morocco, Algeria, and Tunis. England controlled Egypt and Cyprus, leaving only Tripolitania left to Italy. The Italian press noted frequent frontier encroachments by the French and British in Tunis and Egypt respectively. France was rumured to be interested in Ghadames, while British designs were on Tobruk. ${ }^{65}$

The C.U.P. controled Porte envisioned reforms included economic treaties favorable to Istanbul, and Italy feared that Germany intended to supplant Italy as the primary economic interest in the Vilayet. Italian banks had begun to sell economic enterprises in the region to German banks and Giolitti's hurry to occupy the Vilayet indicates that Rome feared political penetration by German economic interests in

(London: His Majesty's Stationery' Office, 1932), 247-248.

${ }^{64}$ F.O. 6027/6027/12/12, No. 38, Rodd to Grey, Rome, 12 February 1912. In Gooch, Vol. IX, Part I, 260-261.

${ }^{\circ 5}$ For a complete review of the ground campaign in North Africa, see W.K. McClure, Italy in North Africa: An Account of the Tripoli Enterprise (London: Constable and Company Ltd., 1913), 32. 
Tripolitania. ${ }^{60}$

The key factor for any military operation along the Tripolitanian coast was weather. Winter sea conditions preclude landings at undeveloped beach heads and Italy would be risking unacceptable casualties if the Ottomans were allowed to fortify Tripoli and Torbruk over the winter months. Sea states above level three would devastate landing forces, and to expect such troops to assault fortified positions would repeat the Anda Alagi fiasco. Any military action had to proceed before October 1911 in order to inject sufficient forces to pacify the small Ottoman garrison before weather conditions became unfavorable.

Giolitti needed to create an excuse in Tripolitania to justify military action. The commercial inequalities caused by the absence of capitulations and the threat of a boycott of Italian merchantry were seized upon by the Italian press. Rome papers reported, "...Italian interest being unfavorably rated when compared to other powers." Italian honor and national pride were played upon to incite support for drastic action. ${ }^{67}$ German newspapers such as the Hamburg Zeitung warned Italy "that if she [Italy] does not wake up, Tripoli could fall under the influence of France and other Powers." Italian opposition papers such as Rome's Giornale d'Italia and Naples' Mattino demanded not only Tripoli but also other unspecified territories needed to be acquired to restore the equilibrium in

"Thomas Nelson Page, Maly and the World War (New York: Charles Scribner's and Sons, 1920), 118-121.

${ }^{67}$ F.O. 32717/23313/11/44, No. 93, Grey to Rodd, London, 16 August 1911. In Gooch, Vol. IX, Part I, 266. 
favor of Italy. ${ }^{68}$

Internal politics of Italy manifested a situation where Biolitti was confronted with the Italian version of a "Young Turk" movement. A vocal majority of Italians demanded action over Tripolitania, and Giolitti's own party demanded such action or the prime minister, Giolitti, would be replaced. Giolitti learned on 14 September 1911 that a boycott of Italy had started in Tripolitanian ports. This news provided Giolitti his justification for action, and the Italian fleet was ordered to Spezia from Maddalena. ${ }^{69}$

Ottoman diplomatic personnel throughout Europe attempted to obtain assistance from accredited governments to prevent the conflict. This "eleventh hour" diplomatic attempt failed because of internal politics in both countries. Had Giolitti backtracked, the more radical elements of government would have replaced him. For the C.U.P. in Istanbul, accommodation with Italy could create a civil war, and thus the Young Turks faced or losing everything. The Porte could not provide troops adequate to defend the provinces but Istanbul dispatched the freighter S.S. Derna with a hold full of Mauser rifles in order to equip the loyal tribesmen. ${ }^{70}$

The Italian government sent a protest on 23 September 1911 over the treatment of Italian interests and Italian nationals. Four days later, Italy issued an ultimatum that consent must be given within 24 hours to an Italian military occupation of Tripolitania

${ }^{68}$ F.O. 35685/30691/11/44, No. 138, Rodd to Grey, Posilipo, 4 September 1911. In Gooch, Vol. IX, Part I, 268.

${ }^{69}$ F.O. 37412/30691/11/44, No. 143, Rodd to Grey, Posilipo, 14 September 1911. In Gooch, Vol. IX, Part I, 270. See also Hurd, 33.

${ }^{70}$ McClure, 49. 
and Cyrenaica. Rome believed Istanbul would not fight and dispatched a party of Italian journalists to Tripoli in order to document the changing of sovereignty. Once the Italian fleet arrived and Ottoman forces retreated into the desert, the journalists had to be rescued from lawless tribesmen out to loot the city. ${ }^{71}$

The Italian allegations had no merit. Ottoman civil control in Tripolitania and Cyrenaica had been lax before the Young Turk government came to power. Istanbul's refusal to submit to economic concessions in Anatolia and North Africa was directly a result of the Ottoman government's attempt to establish economic and governmental control: control that Italy demanded. At the end of 24 hours, at 2:30 pm on 29 September 1911, a state of war existed between Italy and the Ottoman Empire. ${ }^{72}$ Istanbul fully understood the situation in Tripolitania and Cyrenaica. Ottoman naval forces were inadequate to confront the Italians. British naval advisors, owing to the clause in the contract for services which released British officers from advising in times of war, were withdrawn on 30 September $1911 .^{73}$ The British would return to non-hostile positions by 8 October 1911. Ottoman fleet exercises, which were occurring in Syrian waters, were concluded early, and the fleet withdrew to the safety of the Dardanelles by 2 October $1911^{74}$

"II Ibid., 38.

${ }^{22}$ Albertini, 343.

${ }^{73}$ Gooch, Vol. IX, Part I, 282.

${ }^{74}$ Güleryüz, 15. 
The Ottomans appealed again to England for some sort of rapprochement with Italy. Ottoman Grand Vizier Said Halem Pasha appealed to England's King George V, offering to enter the Empire into the orbit of the Triple Entente if London would intercede on the Ottomans' behalf. Said Pasha offered an arrangement by which Tripolitania would end up a protectorate of Italys' with the Sultan's rights acknowledged. ${ }^{75}$ England refused to assist because Egypt's Lord Kitchner preferred a Christian controlled Tripolitania and Cyrenaica, and English policy towards the region mirrors his views. ${ }^{70}$

On paper, the armies of the belligerents were equal. However, since Ottoman ground forces were based in Anatolia and not North Africa, the numbers are misleading The naval forces for the two countries are found in Table 3.

The Ottoman navy was experiencing a reduction in personnel under the guidance of the English Rear Admiral H.P. Williams. The uncertainty and politics surrounding such reductions had to affect readiness. The Ottoman navy experienced a reduction from a high of 31,000 personnel in 1908 to 7,000 in 1912. The Ottoman naval structure and commanders are listed in Appendix 3.

The Italian fleet was divided into three squadrons with two divisions in each squadron. Table 4 shows the constitution of the Mediterranean Italian fleet. ${ }^{77}$ The third

${ }^{35}$ F. O. 43470/43250/11/44, H.M. George V to Grey, London, 2 November 1911. In Gooch, Vol. IX, Part I, 780.

${ }^{76 F}$. O. 43250/43250/11/44, Grey to Twefik Pasha, London, 2 November 1911. In Gooch, Vol. IX, Part I, 780.

"7F.O. 37773/30691/11/44, No. 151, Rodd to Grey, London, 22 September 1911. In Gooch, Vol. IX, Part I, 274. 
TABLE 3

ITALIAN AND O'TTOMAN NAVAL FORCES AT THE START OF THE ITALO-OTTOMAN WAR

Type of Ship

Battleships

Coastal Defense

Cruisers

Destroyers

Torpedo Boats $\underline{\text { Italy" }}$

14

10

20

41

90
Ottoman Empire"

2

2

3

8

9

"Jane, All the World's Fighting Ships 1914, 286-299.

Ibid., 409. 
TABLE 4

COMPOSITION OF THE MEDITERRANEAN ITALIAN FLEET

FIRST SQUADRON

COMMANDING OFFICER

VICE ADMIRAL AUBRY

Prince Ludwig Amadeus, Duke of Abrussi

(Division Commanding Officer)

Vitorio Emanuele

Pisat

Regina Elena

Amalfi

Napoli

San Marco

Roma

San Giorgio

SECOND SQUADRON

COMMANDING OFFICER

Vice Admiral Faravelli

Rear Admiral Count Thaon di Revel

(Division Commanding Officer)

Benedetto Brin

Giuseppe Garibaldi

Regina Margherita

Varese

Saint Bon

Feruccio

Emanuele Filiberto

Marco Polo

Source: Archibald Hurd, Italian Sea-Power and the Great War (London: Constable and Company, LTD, 1918), passim. 
detachment of small Italian warships was based in Somaliland at Mogadishu and would be augmented by the following cruisers: R.I.S. Piemonte, R.I.S. Artigliere, R.I.S. Calabria, and R.I.S. Puglia.

In all three naval detachments, subsidiary forces, destroyers, seagoing torpedo boats, supply and repair vessels followed. Additional logistic requirements for the evacuation of foreign civilians from Tripolitania and Cyrenaica necessitated leasing commercial passenger ships. Break- bulk and cargo ships were also acquired to augment littoral and ground- force supply requirements. The short time period from ultimatum to warfare caught procurement, maintenance, and movement planners scrambling to contract commercial carriers to fulfill Italian Army requirements. The delay pushed back deploymenting ground forces until the second week of October.

The Italian navy was prepared for combat and in place by the ultimatum's deadline. Italian army forces were not prepared suggesting ground-force commanders were kept out of the communications loop and were unaware of the impendin conflict. The Italian army had reciently release from active duty the 1889 class of conscripts on 3 September 1911. After the ultimatum had been issued, the 1888 class and the just-released 1889 class had to be recalled to active duty. Adding to the Italian army's unpreparedness was the fact that summer ground maneuvers had just concluded on 1 September. No logistical planning for the occupation of Tripolitania seems to have begun. The orders for mobilizing army corps for transport were not issued until 25 
September, and the first army troop transports did not leave Naples until 9 October. ${ }^{78}$ General unpreparedness and overconfidence manifested themselves quickly. Ships were ordered to sail with one day's provisions aboard. The Italian General Caneva, Commander of Ground Forces, had little idea how to fight a mobile war against guerrillas and embarked only 20,000 troops. $^{74}$ Finally, Italian battalions never reached war strength, which would result in newspaper errors in reporting Italian personnel numbers.

The naval war began the same day that the ultimatum expired. Prince Ludwig Amadeus, The Duke of Abrussi and cousin to King Victor Emmanuel II, shelled the Ottoman base at Preveze. The torpedo boats Antalya and Tokad, en route to Singin (Albania), were attacked off Kalamic (Greece) by Italian destroyers. Tokad fled north and was followed and shelled by Italian warships, with the loss of nine men. Antalya, pursued by two Italian warships, managed to reach base at Preveze with slight damage. ${ }^{80}$ Moving down the Adriatic coast of the Ottoman Empire, the Italians sank the torpedo boats Hamidiye and Alpagot at Resadiye (Igoumenitsa, Greece). The royal yacht Trablus, undergoing boiler repairs, was scuttled in the harbor, but an Italian boarding party managed to close the sea cocks.

Admiral Aubry's division, Vitorio Emanuele, Regina Elena, Napoli, and Roma, was deployed to the Anatolian coast in order to prevent the Ottoman fleet from sailing to

${ }^{78}$ Albertini, 344.

${ }^{79}$ Denis Mack Smith, Italy: A Modern History (Ann Arbor, MI: University of Michigan Press, 1959), 278-280.

${ }^{80}$ Güleryüz, 15; F.O. 38784/30691/11/44, No. 162, Rodd to Grey, Rome, 1 October 1911. In Gooch, Vol. IX, Part I, 294. 
the Tripolitanian provinces. Political vacillation in regard to Vienna's and Rome's desire to localize the conflict prevented the Duke from destroying the Ottoman fleet outright. Rome order to intercept the Ottoman fleet was altered to seize Tobruk immediately suggesting a fear that English or Egyptian forces might lay claim to Cyrenaica. ${ }^{81}$ Ottoman naval forces were not as high a priority as was preventing English expansion into the region.

The Duke of Abrussi placed a blockage on the Ottoman Adriatic coast and immediately created a diplomatic incident. Blockading the coast upset the status quo, and Austria objected to warfare being injected into the volatile Balkans. ${ }^{82}$ Italy reacted by moving the Duke's force to the vicinity of the Dardanelles in order to combat any sortie attempted by the Ottoman fleet.

Unaware of the Italy's true intentions, the Ottomans began strengthening the defenses at Selanik and Izmir. In addition, the approaches to Yenikale by the Gulf of Izmir were blocked by scuttling the old Osmanli Steamship line steamers Adana and Saadet. The Sultan's yacht, Sultaniye, and the transport Izmir were also released by the navy for scuttling and a mine barrage was laid in order to protect Yenikale. ${ }^{83}$

The landing of the Italian marines at Tripoli, with no follow-on forces to press the objective, alerted the native populace and altered the Italian occupation-force commander Admiral Canevaro's plan to seize the hills surrounding the town. A more serious problem

${ }^{81} \mathrm{McClure}, 215-216$.

${ }^{82}$ Hurd, 34-35.

${ }^{83}$ Güleryüz, 15. 
resulted when the resident population did not embrace the Italians as liberators. Though the Ottomans were not Bedouin, once the Italians began shelling Ft. Hamidieh and Ft. Sultanieh in Tripoli on 3 October, the fleeing population seemed to have sided with the Sultan. The shelling of towns within naval gunfire range, such as Derna on 16 October, Benghazi on 19 October, and Homs on 21 October, drove urban Bedouins into desert camps for succor.

The resident population of the Vilajet of Tripolitania consisted of Berbers and Arabs with Negroes in the Fezzan Region. Arab Bedouin tribes, nomadic in nature except for the urban dwellers, paid little allegiance to the Ottoman officials, keeping to marriage and tribal loyalties. Tripolitania had no manufacturing except for local consumption, and business, if any outside of subsistence, revolved around caravan routes through Feezan. Seizing oasis towns vital to caravan trade had been the motivation for France to expand into the French Sahara. Maintaining control and regulation of trade on the caravan routes would be a prime directive for Italian occupation forces.

The dominant Islamic Order in Tripolitania and Cyrenaica was the Sanusiya, or Sanusi, founded in 1837 by Sayyid Muhammad bin Ali al-Sanusi. Directly descended from the Prophet Muhammad, Sayyid Muhammad bin Ali al-Sanusi, or Grand Sanusi, was born in 1787 in Morocco. ${ }^{84} \mathrm{~A}$ fraternity and not a sect, the Sanusi had lodges across North Africa. Disagreements with French colonial administration forced the Sanusi out of Algeria, Chad, Morocco, and Tunis into Tripolitania and Cyrenaica. When the Italian 1949), 11.

${ }^{84}$ E.E. Evans-Pritchard, The Sanusi of Cyrenaica (Oxford: Clarendon Press, 
war spread into Tripoli and Banghazi, the Sanusi organized the native Bedouin tribes to resist. ${ }^{85}$ The Sanusi may not have embraced the Sultan's government, but replacing an Islamic monarch with an Christian was not in the fundamental Islamic fraternity's best interests.

When the war began, Istanbul had 3,010 men in Tripolitania and 1,200 men in Cyrenaica. ${ }^{86}$ Under normal circumstances, these forces would have been twice as great, but $g$ to an English-inspired revolt in Yemen diverted troops to Arabia in early 1911.Ottoman governmental policy in the two provinces was benign neglect. Sayyid Ahmad al-Sharif, the leader of the Sanusi at the time of the war, controlled the oasis and caravan area, maintaining peace and order, while Ottoman authorities controlled the urban area. The Sanusi kept in check Bedouin warfare and acted as a governmental extension in the Fezzan.

Once the conflict began, Ottoman forces fell back into the desert and took advantage of the Sanusi social structure to begin defensive operations. Mustafa Kemel, the future president of modern Turkey, came over across Egypt and organized Bedouin tribal forces. Enver Bey, future Ottoman War Minister, also crossed Egypt and initiated guerrilla action. A third camp set up by Aziz Bey al Masri utilized Bedouin forces in eastern Cyrenaica ${ }^{87}$ Aziz Bey also received assistance from Bedouins residing in Egypt

${ }^{85}$ Emrys L. Peters, The Bedouin of Cyrenaica (London: Cambridge University Press, 1990), 17-19.

${ }^{86}$ Evans-Pritchard, 108.

${ }^{87}$ Ibid., $110-111$. 
until Lord Kitchner of Khartum, British Consul-General in Cairo and future English secretary of war, reminded the Bedouins that "... present Egyptian law precluded their conscription into military service, but if the Bedouins were so inclined for military service, he [Kitchner] would see to changing the law." ${ }^{88}$ This threat slowed but did not stop Egyptian Bedouins from aiding Ottoman forces in Cyrenaica. England also refused to allow Ottoman troops to cross Egyptian territory or Ottoman naval forces to utilize Egyptian littoral regions. ${ }^{89}$ Aiding Istanbul were the French authorities who did little to prevent the flow of supplies from Tunisia. Ottoman military operations received personnel and gold through French Tunisia and in order to prevent or restrict such supplies, Italian forces were landed at Zuara. Regardless of Italian efforts, the border remained porous and Ottoman supplies continued to trickle in. ${ }^{90}$

On 17 October 1911 the German charge d'affaires in Cairo, Richthofen, reported that the Egyptians desired to send 18,000 troops into Tripolitania to aid their suzerain, the Sultan. Lord Kitchener agreed, but stipulated that since Egypt could not be left unprotected, the 18,000 Egyptian troops would have to be replaced with 18,000 English troops. The Egyptians dropped the offer.'

${ }^{88}$ E.T.S. Dugdale, German Diplomatic Documents, $1871-1914$, Vol. IV (London: Harper and Brothers, 1922), 62.

${ }^{89}$ F.O. 38306/30691/11/44, No. 72, Radd to Grey, Rome, 30 September 1911. In Gooch, Vol. IX, Part I, 286.

${ }^{90} \mathrm{McCl}$ Clure, 150.

${ }^{9}$ Dugdale, German Diplomatic Documents, Vol. IV, 61-62. 
Either England and France could have secured the borders with Tripolitania and Cyrenaica, but diplomatic intrigue dictated that Italy should bleed and incur expenses far beyond the minimum to secure the territory. Not until Italy shifted foreign policy away from Berlin did military contraband from Tunis and Egypt slowe. ${ }^{92}$

In October 1911 Italy approached England in order to get an understanding on the Red Sea. Italy feared Ottoman Arab forces being transported either by sea or the Hejaz Railway. Injection of such forces would make conquest of Tripolitania more difficult. ${ }^{93}$ Italy again received assurances of Egyptian neutrality and assurence that no Ottoman troops would be allowed to cross the frontier into Cyrenaica.

Bedouin forces harassed Italian forces throughout the war. Whenever Italian forces ventured beyond naval gunfire support into the open desert, the Bedouin/Ottoman forces engaged in a guerrilla campaign, draining Italian morale and resources. Italy had planned to commit less than 34,000 troops to conquer the provinces. However, warfare, disease, and sheer size of the operation forced the occupation troops upward to 100,000.As the conflict dragged out, the war evolved into an Italo-Sanusi struggle. The Sanusi, keeping to the basic concept that the Order adheres to in religion, transferred primal emotions to the war and thus changed the war into a struggle to throw off the yoke of a foreign power. ${ }^{94}$ The fight for Tripolitania and Cyrenaica became more brutal.

${ }^{92} \mathrm{Ibid} ., 63$.

${ }^{93}$ F.O. 40481/30691/11/44, No. 162, Grey to Rodd, London, 11 October 1911. In Gooch, Vol. IX, Part I, 306.

${ }^{94}$ Evans-Pritchard, 110. 
Prisoners were few, and Enver Bey, when leading troops, showed a disposition towards high Arab casualty figures. ${ }^{95}$ Istanbul tried to supply the Sanusi with whatever meager resources were available. The Ottomans set up an agency at Marseilles to smuggle contraband through Tunis to Tripolitania. The supply line through Egypt, begrudgingly allowed by Kitchener, was strictly controlled by the British. France did little to stop supplies from reaching Tripolitania. However, on the nights of 16 and 18 January 1912 the Italian warship R.I.S. Agordat stopped the French steamers S.S. Carthage, with an aeroplane aboard that the Italian believed destined for Tunis, and the S.S. Manouba, carrying twenty-nine Red Crescent relief workers. The diplomatic uproar in France demanded respect for the French flag, and Rome, fearing a diplomatic break with perturbed Paris, acquiesced. ${ }^{96}$ However, the episode demonstrates the wherewithal the Young Turks exhibited towards defending the Empire.

The Russian ambassador in Rome reported to the English foreign secretary, Sir Edward Grey, that Italy had planned to force the straits and engage the Ottoman fleet in the Sea of Marmara. ${ }^{97}$ Such an attack might have fulfilled romantic visions of Italian naval superiority; however, it would have been disastrous. Forcing the straits would include engaging land fortifications, possible mined channels, and navigational courses textbook for Ottoman torpedo attacks. On 12 November 1911 the Italian ambassador in

${ }^{95}$ McClure, 199.

"Albertini, 355-356.

${ }^{27}$ F.O. 44140/30691/11/44, No. 305, Lowther to Grey, Pera, 7 December 1911. In Gooch, Vol. IX, Part 1, 322. 
St. Petersburg, Russia informed the Russian minister for foreign affairs that Italy would not force the Dardanelles in order not to inconvenience other powers, however, the Russians were led to believe that Rhodes might be the next target for Italian naval power. $^{98}$

The Italians proclaimed the annexation of Tripolitania and Cyrenaica on 5 November 1911. This was in direct violation of the Treaty of Paris of 1856 and the Treaty of Berlin of 1878 , both of which guaranteed the integrity of the Ottoman Empire. The proclamation seems to have been directed at Italian domestic consumption for reality found the Italians in charge of coastal villages and little else. An indication of the resistance can be found in British messages discussing Italian massacres of Moslem civilians in Tripoli. Such criticism of Italy fueled nationalist papers and placed Italo-English relations in a chill. ${ }^{99}$ The annexation decree inspired the Ottomans to fight instead of negotiate. Determined to hold on for pride, the Porte's position indicated a belief that the Italians did not have the staying power to hold on if the conflict dragged out. Additionally, unconfirmed English newspaper reports of Italian cruelties on women, children and the aged followed a too-familiar pattern of Christian excesses of Muslim refugees.

The Sanusi resistance became fanatical after Italian Christian bishops talked of a crusade. The Arabs responded with a calling for a "jihad," or holy war. Since Arab

${ }^{98}$ F.O. 44772/30691/11/44, No. 272, O'Beime to Grey, St. Petersburg, 12 November 1911. In Gooch, Vol. IX, Part 1, 322.

${ }^{9}$ Sir R. Rodd to Sir E. Grey, 14 November 1911. In Gooch, Vol. IX, Part I, 322. 
fighters had few if any uniforms, ununiformed prisoners were by Italian definition spies and subsequently hanged. Enrico Corradini, an Italian journalist and nationalist politician, described Arabs in general as savage beasts who should be whipped, and those opposing Italian liberation from Ottoman rule deserved only to be hanged. ${ }^{100}$

The Ottoman government and foreign diplomatic circles in Istanbul envisioned the widening of the war to other areas of the Sultan's domain. Diplomatic intrigue narrowed down the areas: England "protected" Egypt, Sudan, Smyrna, Salonika, and the Dardanelles because of maritime trade and Austria-Hungary placed the Balkans off-limits. ${ }^{101}$ The Red Sea was the only legitimate area outside of Tripolitania to exert pressure on Istanbul.

In December 1911 Italy reinforced the Italian forces in the Red Sea. Injection of naval forces into this theater was in direct violation of the Italian Memorandum issued on 11 October 1911 expressing the neutralization of that region. There is no evidence that Istanbul violated the memorandum, and with England preventing the overt passage of troops through Egypt and the Ottoman fleet hunkered down in the Sea of Marmara, Italian internal politics would to be the rational explanation. On 5 December 1911 the Italian cruiser Puglia shelled the Sinai town of Akkaba and sank the Ottoman gunboat Halic. The Puglia then stopped the Ottoman merchant ship M.V. Kayseri en route from Suez to Kunfada with coal. The most substantial confrontation between Italian and

${ }^{100}$ Smith, 278.

${ }^{101}$ Baron von Marschall to German Foreign Office, 14 November 1911. In Dugdale, Vol. IV, 65. 
Ottoman naval forces occurred on 7 December 1912 at the Ottoman Naval Station at Kunfada.

The Italians had shelled Mocka and Sheikh Said at the south end of the Red Sea along with Akkaba in the Gulf of Sinai in early November. ${ }^{102}$ The Ottoman naval forces, gunboats Kastamonu, Ayintab, Ordu, Bafra, Refahiye, Gokedag, the armed tug Muha, and the yacht Sipka were hiding in the internal canals of the Farsan Islands. Ottoman ground forces occupied Loheia, Ft. Midi, and Kunfada.The Italians shelled Jebel Tahr on 7 January 1912 with the cruisers Calabria and Puglia, while the Italian cruisers Piemonte, R.I.S. Garibaldino, and Artigliere drifted down the coast to Lith. Loheia and Ft. Midi were bombarded by Puglia and Calabria, forcing the Ottoman gunboats to scatter back to Kunfida. The Ottoman gunboats broke and fled and the Italians systematically sank the all of them. Ground forces at Kunfida engaged in shelling the Italian cruisers; however, the Italians stayed outside of the land batteries' range during most of the three-hour engagement. ${ }^{103}$ The Ottoman forces seemed to be tempting the Italians into the canals because restricted maneuverability on the part of the Italian cruisers would have placed the ships in position for torpedo runs or triangulation from shore/ship gunfire. Italian warships were visually pleasing, however, protection from direct fire had been sacrificed in order to gain speed and reduce costs.

\footnotetext{
${ }^{102}$ Hurd, 36.

${ }^{103}$ Hurd, 36-37; Güleryüz, 16.
} 
The raid into the Red Sea during January 1912 occurred during the same time period of peace negotiations, which started on 12 December 1911 and would last until 15 October 1912. The Ottoman government recognized that Tripolitania and Cyrenaica were lost, but concern for internal elections, Islamic fears of Christian excesses, and the indignation of the foreign community pressuring Istanbul to give up, encouraged the Young Turks to continue. The Porte did float a feeder that the provinces could be ceded to a Mohamidan chief, either Karamanli Bey, the Egyptian Prince Fuad, or the head of the Sanusi, Sayyid Ahmed al-Sharif. Then the question of Ottoman relinquishing sovereignty under duress would be less of an internal issue. Italy would not retract the annexation decree, and the suggestion went nowhere. ${ }^{104}$ Istanbul did want some sort of accommodation with Italy. The prospect of an ethnic war in the Balkans began to appear probable, and the Porte began to reinforce quietly key points in the region.

The Italian VADM Thaon de Revel moved the naval operation out of the Red Sea up to the Lebanese coast in January 1912. The cruisers R.I.S. Giuseppe Garibaldi and R.I.S. Francesco Ferruccio shelled Beirut on 24 January 1912. The Ottoman stationary ship Avnillah was set ablaze. From 0930 hours to 1100 hours, the Italians shelled the Avnillah and then Beirut itself. At 1100 hours, the Giuseppe Garibaldi entered the harbor and torpedoed the Avnillah, killing two officers and $49 \mathrm{men}$. The Ottoman gunboat Ankara, also in the harbor at Beirut, was scuttled by the crew. Over 140 civilians were

${ }^{104}$ German Ambassador to Rome, Herr G. von Jagow, to Chancellor BethmannHollweg, 4 July 1912. In Dugdale, Vol. IV, 70. 
killed and 200 injured during the bombardment. ${ }^{105}$ Austria protested the shelling because it potentially opened and widened the war. ${ }^{106}$ After the shelling, Italian civilians in the Sam (Damascus), Beirut, and Halpe (Aleppo) areas, who up till then had lived peacefully within the Ottoman Empire, began to fear retaliation and over 55,000 were compelled to leave. ${ }^{107}$

With few real military targets and no action whatsoever to land troops and seize territory, Italian bombardment of civilian areas in the Red and Mediterranean Seas suggest an attempt to inspire civil unrest within the Ottoman Empire. Internal pressure to protect Anatolia, the flow of Muslim refugees, and the tinderbox Balkan region may have influenced Abdul Hamid's regime, but Young Turks were not so timid. The need to conclude this conflict rested in Tripolitania and not Anatolia. Italian ground forces were not winning and diseases such as malaria and dysentery had sapped the morale of the conscripts. What was supposed to be a quick victory had lapsed into a quagmire.

The Italians moved up to Samos and bombarded the town on 18 April 1912 sinking the royal yacht lhsaniye. The same day, the Giuseppe Garibaldi and the R.I.S. Varese shelled the Dardanelles forts of Seddulbahir and Kumkale, inflicting heavy casualties. The Italians also cut underwater telegraph cables belonging to the Eastem Telegraph Company between the island of Imbros and the mainland, and between Lemnos and Tenedos and Lemnos and Salonika. On the same day, the Italians shelled

$$
\begin{aligned}
& { }^{10} \text { Güleryüz, } 16 . \\
& { }^{106} \text { Giolitti, } 296 . \\
& { }^{107} \text { Güleryüz, } 16 .
\end{aligned}
$$


the Ottoman barracks at Vathy on the island of Samos and cut the underwater cable between the islands of Rhodes and Marmarice. ${ }^{108}$ The obvious progression to the Straits forced Istanbul to place the Ottoman fleet at the promontory of Kilid Bahr.

The Porte closed the straits on 20 April 1912 and mined the approaches to the channels at Canakkale resulting in trapping over 170 merchant vessels in the Sea of Marmara. During the war, the Ottomans did not stop Italian flagged vessels from transiting the strait and continued business as usual. It was only the fear of a possible forcing of the straits by Italy's navy that the Porte engaged in such defensive tactics. Istanbul relied on sea-borne commerce and long-term closure of the straits could ruin the fragile Ottoman economy but English ships bore a large percentage of Russian cargo through the straits, closure got both London and St. Petersburg 's attention. Ship owners were losing $\$ 489,000$ each day the strait was closed and both Russian and English shippers who had profited from the war now demanded action. ${ }^{102}$

The Porte reopened the straits on 1 May 1912 and diplomatic exchanges between the Powers assured that if any attack upon the straits or possible attack should arise, the Porte had the right to close the channel. If such should occur, Rome, and not Istanbul, would be at fault. The fact that Britain could constrain Italy when English commerce suffered did not go unnoticed. Mahmud Shevket Pasha, Ottoman minister of war, stated

${ }^{108}$ Viscount Hythe, The Naval Ammal 1913 (Portsmouth: J. Griffin \& Co., 1913; reprint, New York: Arco Publishing Company, 1970), 192.

${ }^{109}$ F.O. 18473/8565/12/44, No. 260, Grey to Lowther, London, 30 April 1912. In Gooch, Vol. IX, Part 1, 390. 
to Major Tyrrell, military attaché at the British Embassy in Istanbul, "...if England chose to forbid Italy to do this or that in the Mediterranean or elsewhere, she would have to obey, and there would be no question of war with her [Italy]."110 Shevket Pasha was making a statement proved by the fact that Italy spent twenty years arranging treaties, protocols, and agreements that Tripolitania was Rome's to have. Had Britain or France, the dominant powers in European affairs, objected to Italy's seizing Tripolitania, the war might not have taken place. Shevket went on to state, "The truth of the matter is that you (Britain) and France are trying to detach Italy from the Triple Alliance. Germany and Austria are trying to keep her there."11" The position of Italy, desired by both hostile camps, gave Rome the carte blanche needed to seize Tripolitania and Cyrenaica.

The war in Tripolitania and Cyrenaica was going badly for the Ottomans. Two years of drought, along with disease and the high casualty rate experienced when untrained irregulars charged trained soldiers, had decimated the Bedouins. Whatever side held out longer would be the victor, and in Spring 1912 neither party looked to be prepared to compromise. Rome expanded the war again when Italian naval forces under Vice-Admiral Amero and ground units under the command of General Ameglio occupied Rhodes on 4 May 1912. Ottoman troops refused to surrender and waged a guerrilla campaign until overwhelmed on 17 May. The other Dodecanese islands fell by 16 May Part I, 392.

${ }^{110}$ Letter to Sir Lowther from Major Tyrrell, 29 April 1912. In Gooch, Vol. IX, "11'Ibid. 
1912 and in retaliation, on 20 May 1912 the Porte expelled 70,000 Italian nationals from Ottoman territory. ${ }^{12}$ The Dodecanese island chain consisted of fifty islands. Greek for "twelve islands," the largest being Rhodes. Many geographers apply the term "southern Sporades" to the Dodecanese to denote the political separation in place in 1912. . The islands had been Ottoman Territory since 1522, having fallen to Suleiman the Magnificent. By the end of May, Italy had occupied Scarpanto, Kasos, Episcopi, Nisyros, Kalymnos, Leros, Patmos, Kos, Symi, and Khalki. This occupation was only "temporary" due to Article Seven of the Triple Alliance Treaty giving Austria sway in the Aegean Sea basin. Italy claimed the islands were in the Sea of Crete and thus open to seizure. Austria reluntently agreed to a temporary occupation until hostilities ceased. ${ }^{1 / 3}$ In order to consolidate defensive positions, the Ottomans began to withdraw troops from Samos in early July. An Italian destroyer interfered and was taken under fire, resulting in two Italian deaths. In retaliation Italian warships shelled the village of Plaka, destroying shipping and port facilities. ${ }^{114}$

The final naval action of the war happened on the evening of 18 July 1912. The Italian naval Capt. Enrico Millo set out with a torpedo squadron of twenty boats up the Dardanelles Strait as far as Kephez Point. His objective was to attack the Ottoman fleet's German-built battleship Torgud Reis and Barbaros Hayreddin. Any attempt to force the Dardanelles would be hazardous if the two battleships were still capable of inflicting

\footnotetext{
${ }^{112}$ Albertini, 360.

${ }^{113}$ Dickinson, 88 .

${ }^{114}$ Hythe, 196.
} 
damage. He got within sight of the Ottoman fleet at Kilid Bahr before his flotilla became entangled in the steel cable boon placed across the channel. Millio did not launch his torpedoes because of the range and Ottomans shore batteries forced him retreat to the open sea. ${ }^{115}$

The occupation of the Dodecanese brought Italy no nearer to ending the war because Rome was prevented from striking the Ottomans at a vital spot, the Straits. In Tripolitania and Cyrenaica, Italian troops overcame enemy opposition and extended their occupation zone. On the caravan routes, the Italians seized oasis stops and halted the contraband trade. The French attempted to persuade the Ottomans to come to terms, but all attempts failed due to the Italian annexation decree.

Actual peace negotiations began on 12 July 1912 in Ouchy, Switzerland. Germany acted as mediator to the distress of Britain. London was concerned that Italy might bargain to get the Dodecanese as well as Tripolitania and Cyrenaica. The Egyptian prince, Said Halim, started the negotiations, but by 12 August a change of government in Istanbul brought Naby Bey and Fehrreddin Bey. ${ }^{116}$ The talks dragged on until 8 October 1912, when Montenegro declared war on the Ottomans. Rome was so determined to exploit the Balkan crisis that the Italian first squadron was ordered to be ready for action in the Aegean Sea. Istanbul was facing bleak choices: conclude a peace of some sort, or fight a Balkan war with Italy controlling the sea.

${ }^{115}$ Hurd, 38; Güleryüz, 16; and Hythe, 196-197.

${ }^{116}$ McClure, 177. 
The Ottomans hedged and played for time. The commander of Ottoman forces in Tripolitania, Aziz Bey, informed the Porte that if peace were concluded unfavorably to the Arabs, the Senusi were prepared to carry on the war on their own. Arab committees in the Empire had threatened that if Tripolitania were ceded, it could lead to the abolition of the Caliphate. Faced by ethnic insurrection in Macedonia and Albania, and a threat of outright warfare from Greece, Bulgaria and Serbia, the Porte concluded peace by decree-law without approval of parliament. The peace preliminaries were signed at Ouchy on 15 October 1912. ${ }^{117}$ The formal signing of the peace agreement, the Treaty of Lausanne, occurred on 18 October 1912. Kiamil Pasha, Grand Vizier under deposed Abdul Hamid and now back in power under Mehmet $V$, artfully crafted the final copy of the treaty, implying both Italian and Ottoman control of Tripolitania.

The document appears to have been drafted with the intent of ambiguity and intrigue. The Italians desired the Ottomans to withdraw their forces from north Africa believing that the Arab population would at once submit. In return for this the Italians were prepared to make what appeared to be a purely nominal concession by permitting the Arabs to continue to recognize the Sultan as their Caliph and to have relations as such through the Sultan's representative at Tripoli. The Ottomans were faced with loss of prestige for the Sultan in losing a part of the Empire the Porte could not defend. The Italian politicians had promised their people a quick victory without much expenditure in lives and treasure and were prepared to sign any agreement that could be presented as

\footnotetext{
"Gooch, Vol. IX, Part I, 430.
} 
such, without giving much consideration to the implications of what was agreed upon.

The terms of the treaty called for a representative of the Sultan as a liaison between the Caliph and the Arab Muslims. The Sultan's representative, the Grand Qadi of Tripoli, would have religious and, due to the nature of Islam, political authority. The Italians seemed to have been under the impression that the Sultan's secular power could be excluded in return for admitting the Caliph's spiritual authority. The rest of the treaty required the evacuation of Ottoman troops from Tripolitania and Cyrenaica, and such removal of forces would precede that of Italian troops from the Aegean islands; amnesties on both sides; commercial relations; Italian consent to the abolition of the regime of capitulations; and payment by Italy to the Ottoman Public Debt an amount equivalent to the revenues derived from the lost provinces for a length of time to be determined later. ${ }^{118}$

The Ottoman navy did not fare well in the war. The overwhelming superiority of Italian naval assets, planned and utilized to exploit the weakness of the Ottoman navy, performed admirably. But the Porte did not have the resources available to place a formidable opposition in the battle space. Italian naval yards were English-owned, operated, and financed. Ottoman naval yards were the sole property of the financially strapped Sultan. The Italians had full utilization of their economy, while the Ottomans had to contend with the parasitic nature of the capitulations. The Italians were a nationality at peace with itself, while the Ottomans had to deal with rival nationalities, ethnic hatred, governmental chaos, and international meddling in the internal affairs of

${ }^{118} \mathrm{~A}$ copy of the treaty can be found in Gooch, Vol. IX, Part I, 438-442. 
the empire.

Ottoman naval losses consisted of gunboats and stationary guard ships, assets economical to keep and acceptable to lose. Unlike the battleships, gunboats were expendable. Table 5 shows the Ottoman naval assets lost due to the war action. Italian actions suggest a desire for the Mahan theory of one decisive sea battle. The Ottoman navy refused to follow the Italians script of accepting a quick defeat and, Rome's politicians utilized the Italian navy to terrorize Islamic civilians in Ottoman coastal urban areas. Hence the shelling of Beirut, Tobruk, Tripoli, Benghazi, and Kunfada. The Greek population Ottoman cities of Selanik, Izmir, Yenkalf, and Rhodes were not shelled indicating Christian Italians were not prepared to shell Christian Greeks for non-religious reasons.

International political maneuvering involving Ottoman naval personnel may have affected the combat readiness of the fleet. The naval advisor to the Ottoman minister of Marine, English RADM H.P. Williams, could not fully exercise leadership due to clauses dismissing his service in times of war. Williams did continue naval acquisitions during the war, contracting with Vickers in order to follow up on battleship orders to English yards. Williams'term of office under the Ottoman government expired on 28 April 1912, when he sailed for England, accompanied by his staff. Williams' successor, English RADM A.H. Limpus, would arrive in the spring of 1912. ${ }^{119}$ Istanbul desired for the return of Gamble, however, Gamble refused for health reasons. The Porte regretted

${ }^{119}$ Gooch, Vol. IX, Part I, 282. 
TABLE 5

\begin{tabular}{|c|c|}
\hline Ships & Date \\
\hline Kastamonu & 7 January 1912 \\
\hline Tokad & 29 September 1911 \\
\hline Hamidiye (gunboat) & 30 September 1911 \\
\hline Alpagot & 30 September 1911 \\
\hline Sareddin & 3 October 1911 \\
\hline Halic & 5 December 1911 \\
\hline Izmir & 7 January 1912 \\
\hline Gokedag & 7 January 1912 \\
\hline Refahiye & 7 January 1912 \\
\hline Ayintab & 7 January 1912 \\
\hline Ordu & 7 January 1912 \\
\hline Bafra & 7 January 1912 \\
\hline Ankara & 24 February 1912 \\
\hline Spia, & 7 January 1912 \\
\hline
\end{tabular}

\section{Ships Scuttled, Not Due to Combat}

Trabus

Adana

Saadet

Sultaniye

MS Nevada

MS Texas
3 October 1911

3 October 1911

3 October 1911

3 October 1911

\section{Ships Lost to Mines}

Source: Ahmet Güleryüz and Bernd Langensiepen, eds., trans. by James Cooper, The Ottoman Steam Navy 1828-1923 (Annapolis, MD: Naval Institute Press, 1996), 14-17. 
Gamble's refusal to return and accepted another British naval advisor, relieving English fears that Germany would be requested to provide Ottoman fleet leadership. ${ }^{120}$

A naval casualty of the war was the Ottoman cruiser Drama. Ordered in April 1904 it was seized by the Italians in September 1912 and renamed R.I.S. Libia. ${ }^{121}$ A carbon copy of the Armstrong-built Hamidiye, Drama was built by Ansald-Armstrong of Sestri-Ponenti and would see service until 1937.

Diplomatic problems arose when a number of Ottoman officers being trained in Britain completed training and were scheduled to return home. British Foreign Secretary Sir Edward Grey asked for assurances that the returning officers would not be employed during the duration of the war with Italy. The Porte agreed as long as no publicity be given to it. ${ }^{122}$

The resistance shown in the North African theater can be attributed to Ottoman officers. The Ottoman garrison on hand in September 1911 was not adequate to defend the region, however, Ottoman officers Enver Bey, Aziz Bey, and Neshat Bey provided leadership and resourcefulness which resulted in Italy expending unanticipated time and treasure. ${ }^{123}$ The primary losers in the war were the Bedouins of Tripolitania and Cyrenaica. Giovoni Mondaini, quoting Italian occupation figures in his book, Rivista

${ }^{120}$ F.O. 3938, Lowther to Grey, Istanbul, 27 January 1912, cited in Halpern, The Mediterranean Naval Situation, 321.

${ }^{121}$ Güleryüz, 151.

${ }^{122}$ F.O. 371, Lowther to Grey, Istanbul, 16 June 1912, cited in Halpern, The Mediterranean Naval Situation, 322.

${ }^{123}$ McClure, 191-192, 225. 
Coloniale, claims that the population of Cyrenaica was 300,000 in 1911 but by 1915 the population was estimated at 120,000. Bedouins are mostly transient wanderers and such figures are extremely questionable. Non-belligerents do leave areas of combat with total disregard for borders and political authority. Additionally, with a famine lasting since 1909 and Italian control of urban and oasis trading centers, Egypt and Tunis were logical points of gravitation. Had mortality been as severe as Mondaini states, it is questionable the war in Libya could have dragged on until 1932.

The caution Rome showed with the Italian fleet suggests a desire to avoid massive losses of material and pride. The Italians could have rushed the Dardanelles early and chanced ending the war quickly. But this would have entail a risk of losing the pride of the Italian fleet to either the guns of the Dardanelles forts or the Ottoman battleships. Also, had Rome forsaken the risk and forced the straits, shelling Istanbul's Greek population would have brought political repercussions. The issue of the Sultan and a direct assault upon his person would have caught the attention of France and England, both with large Islamic colonies.

The Ottoman navy did as well as could be expected. The Porte did not budget for an offensive fleet, prudently utilizing the Dardanelles and the Bosporus as defensive works. However, the expenditure of vast sums for battleships did not address the security needs of the empire. The battleships were too expensive an asset to utilize and ultimately had to be defended from attack. While the war dragged on during the winter of 1912 , the Porte indicated that a new naval program was needed. Istanbul maintained that in order to protect a coastline of 11,000 miles, nothing less would suffice, and such a 
battle fleet would enable the Porte to cooperate with possible allies in the eastern Mediterranean to check foreign powers anxious to further political or economic concessions. The program consisted of six dreadnoughts, four scout cruisers, twenty destroyers, six submarines, two minelayers, a repair ship, a school ship, and a large drydock capable of handling dreadnoughts. In justification of the expansion, the Ottoman naval staff argued that "the disaster in Tripoli has been the result of the weakness of the fleet, and to ensure against similar accidents occurring in our distant possessions such as those in the Persian Gulf and Red Sea, which are closely bound up with our national existence, a sufficient naval force must be provided to enable us to affect the balance of European Power." 124

The Porte hoped to prevent dismemberment of the Empire by strengthening the fleet. Creation of a naval force capable of defending the peripheries was needed; but circumstances would not allow for such a program. Admiral Limpus did attempt to moderate the Ottoman program by suggesting smaller assets, ships better suited for protection of the Empire's peripheries. However, English shipyards were clambering for the business prospects of the program, and any orders for dreadnoughts London wanted regardless of the British naval mission's better judgment.

${ }^{124}$ F.O. 371/1486/11454, Lowther to Grey, Istanbul, 11 March 1912, cited in Halpern, The Mediterranean Naval Situation, $318,319$. 


\section{CHAPTER III}

\section{THE BALKAN WARS \\ OCTOBER 1912 TO OCTOBER 1913}

It was inevitable that the Balkan states should regard the Italo-Ottoman conflict as an opportunity to fulfill their own territorial aspirations. The Balkan states viewed Ottoman Macedonia as the only avenue of expansion. To further each nation's goals, armed groups engaged in wanton slaughter of Muslims in order to incite the Porte into suppressing Christian nationalists. Any such suppression would invite Great Power interference and possible success, as witnessed in Greece in 1825.

The conflict had three phases: the First Balkan War [8 October 1912 to 17 December 1912], the Second Balkan War [3 February 1913 to 30 May 1913], and the Third Balkan War [29 June 1913 to 29 October 1913]. In the First and Second Balkan Wars, the Ottomans stood alone. In the Third Balkan Way, the previous allies turned on Bulgaria, with the Ottomans siding with the victors.

The cause of the First Balkan War have been directed at the C.U.P. regime and the zeal in which Ottomanization progressed. Nationalities in distant locales of the empire resented the coercion towards a national identity other than the age-old millet system. Accepting a common nationality could have meant the possibility of conscription into the armed forces, acquiring another language, accepting a religion other than their own, or the possibility of the acceptance of a different Christian orthodoxy. Additionally, being 
Muslim had privileges not forfeited lightly.

Another avenue directs the blame on ethnic fighting in Macedonia. Outright warfare between forces loyal to Bulgaria and Greece fought the Albanian Beys and Muslim civilians. However, the competing dominant Christian nationalities were hostile to each other. Also, each Christian nationality had set up schools and religious structures in the hope of legitimizing territorial claims. The non-Islamic population in 1905 in Macedonia shows 647,962 patriarchists and 557,734 exarchists. However, many exarchists were practicing exarchism under duress and not by conviction. ${ }^{125}$ The attempt to influence the fringes of Hellenism via forced acceptance of exarchate bishoprics caused friction and resentment that would fuel the two succeeding wars, when Bulgarian forces attempted to occupy non-Bulgarian regions solely on the basis of established exarchate bishoprics.

Ethnic Bulgarians prior to 1870 belonged to the Greek Patriarch, and nationalist sentiments created appeals to Istanbul for action. Sultan Abdul Aziz issued a firman establishing the Bulgarian exarchate, conferring immediate jurisdiction over fifteen dioceses and providing for a vote in a dozen more. The diocese in question had to vote two-thirds for admission into the Bulgarian church, and in the regions of Macedonia no group could claim outright loyalty or a numerical supremacy, thus creating regions where

${ }^{125}$ Douglas Dakin, The Unification of Greece, 1770-1923 (New York: St. Martin Press, 1972), 160-162. 
the Greek church existed but the majority might be Bulgarian, or vice versa. ${ }^{26}$ But the most plausible cause for the First Balkan War can be attributed to the Triple Alliance Treaty.

During the Italo-Ottoman War, Italy occupied Rhodes and other islands of the Dodecanese chain. The occupation of islands in the Aegean Sea violated the Triple Alliance Treaty between Austria, Germany, and Italy. The treaty stipulated that Italy could seek compensation if the status quo were changed in the Balkan Peninsula, the Adriatic, or the Mediterranean regions by Austria. Austria could submit a claim for compensation to Italy if the latter occupied any islands or places on the coast of Asia Minor or the Aegean Sea and both Italy and Austria had an agreement that neither country should establish control over Albania. ${ }^{127}$

The consequences of the Triple Alliance Treaty were clear. If Austria pressed compensation for Italy's occupation of the Dodecanese, such territorial claims in Ottoman Europe could only be satisfied via the non-Albanian Ottoman Sanjak of Navi-Bazar, a region between Serbia and the region of Albania, an area between the present modern Albania, the Yugoslav region of Kosovo, the former Yugoslav Republic of Macedonia, and the Greek region of Ipiro and Thessaly west of the Vardar River. Austrian control of non-Albanian Ottoman territory would suppress Serbian ambitions for an Adriatic port

${ }_{126} J a c o b$ Gould Schurman, The Balkan Wars 1912-1913 (London: Oxford University Press, 1914), 24-25.

${ }^{127}$ Isabella M. Massey, ed. The Origins of the War of 1914, Vol. I (London: Oxford University Press, 1952), 201. 
and geographical union with Montenegro. The Bulgarian aspiration for Eastern Roumelia and the Aegean Sea would be in jeopardy due to the overwhelming superiority of Austria and the Triple Alliance partners of Italy and Germany militarily. Both nations--Italy and Germany--would be obligated to assist in securing territorial claims submitted by Austria. Greek longing for the unification of Greeks residing in Thrace, Macedonia, and Istanbul could remain a romantic dream if Austria had the opportunity to submit such demands.

The need to act quickly to prevent Austria from following up on Italy's incursion became apparent once the Italian/Ottoman War switched from the region of Tripoli to Beirut and the Dardanelles. Italian occupation of Rhodes and the Dodecanese Islands between 4 May and 16 May 1912 brought the specter of Italy's acquiring a sizable Greek population. In the region of Macedonia, rival guerrilla bands financed by either Greece or Bulgaria staged assaults upon each other and their supporters. Bulgarian guerrillas in the Internal Macedonian Revolutionary Organization (IMRO) fought not only Ottoman authorities but the Greek External Macedonian Revolutionary Organization (EMRO) and Serbian partisans. The Italo-Ottoman War both encouraged and alarmed the Balkan powers. Any action that weakened the Ottoman Empire was welcomed, but there was the fear that Italy might covet territorial acquisitions. Greece in particular feared that Italy might acquire not only the Dodecanese, but also Chios, Mitilini, Samos, and other islands. Protecting Christians in Macedonia was important to Greece but not paramount. Questions about Crete dominated Greek Prime Minister Eleftherid Venizelos. A Cretan by birth, Venizelos seems to have been more concerned with ridding Crete of Ottoman oversight than seizing Macedonia. Bulgaria's King Ferdinand (1908-1918) did not want 
an agreement that lead to war just to free Crete for Greece. Bulgaria placed negotiations with Greece on hold in order to consummate a secret agreement with Serbia's King Peter (1908-1921) and Serbia's client state Montenegro on 13 March 1912. ${ }^{128}$ "...to each other's assistance with all their forces in the event of any Great Power attempting to annex or ever temporarily to invade any part of the Balkan territories which are today under Turkish rule, if one of the parties considered this as contrary to its vital interest and as a casus belli. ${ }^{129}$

Upon securing Serbia's support, Bulgaria solicited Greece once more. Venizelos feared that if Bulgaria and Serbia were successful in a war with a weakened Ottoman Empire, the real loser would be Greece territorial expansion. The agreement with Bulgaria was signed on 30 May 1912 and dated 29 May 1912. ${ }^{130}$ The forces of the Balkan allies complemented each other exceptionally well. The forces also show the area of concern for each nation. The Bulgarians possessed an army of 400,000, and Serbian and Montenegran forces amounted to 250,000..$^{131}$ The emphasis Bulgaria, Serbia and Montenegro placed upon land forces indicates a goal of seizing adjacent territory. Greece

${ }^{128}$ A copy of the treaty can be found in G.P. Gooch and Harold Temperley, eds., British Documents on the Origins of the War: 1898-1914, Vol. IX, Part II (London: H.M. Stationary Office, 1934), 781-784.

${ }^{120}$ Darkin, 192.

${ }^{130} \mathrm{Ibid}$., 194; Dickinson, $311-313$; and Christ Anastasoff, The Tragic Peninsula (St. Louis: Blackwell Wielandy Co., 1938), 177-194.

${ }^{13}$ Cassavetti, 26. 
had a standing army of 28,000 men and capabilities to expand to $200,000 .{ }^{132}$. The Balkan allies individually could not compete with the 400,000 Ottoman forces in the Balkans. The Balkan allies stood a good chance of winning if the Ottomans were denied follow on forces and supplies. Denying Ottoman follow on forces from Anatolia proper required a mobile fleet of small combatants and Athens had such a force in place with additions found in Table 6.

Greek naval forces were adequate not only to seize islands, but to block follow on forces. I.M. Guesohoff, Bulgarian prime minster, when questioning M. Panas, Greek War Minister, over forces available for theater action, was given the reply, "We can place an army of 200,000 men in the field and then our fleet will stop about 400,000 men being landed by Turkey upon the southern coast of Thrace and Macedonia, between Salonika and Gallipoli!"133

The Greek navy had grown in less than twelve years from coastal defense to a modern force capable of extended bluewater operations in less than twelve years. The build up of forces can be attributed to concerns over Crete and the potential action the Ottomans might embark upon to reestablish complete control over the island. Future interdiction of Ottoman forces from Anatolia, along with seizing Greek populated islands in the Aegean still under the control of the Sultan, necessitated mobile forces capable of operating in the littoral regions in and around the Sea of Crete.

\footnotetext{
1327bid., 60-61.

${ }^{133}$ Cassavetti, 31 .
} 
TABLE 6

ADDITIONS TO THE GREEK FLEET, 1900-12

Types of Boards

Year Acquired

Torpedo

\section{Tubes}

\section{Cruisers}

Averoff

1910

Destroyers

Theyella

1906

2

Sphendoni

1906

2

Lonchi

1906

2

Navkratoussa

1906

2

Aspis

Niki

1906

2

Doxa

1906

2

Velos

1906

2

Leon

1906

1912

Panther

1912

Aetos

1912

Ierax

1912

Keravnos

1912

Nea Genea

1912

Torpedo Boats

6 Total

Submarines

Delphin

1912 5

Xiphias

1911 5

Source: D.J. Cassavetti, Hellas and the Balkan Wars (London: T. Tisher Unwin, 1914), 26-31. Greek naval personnel activated during the wars would number 11,232. 
In October 1909, the Greek navy experienced a brief mutiny. Reforms and modernization were needed and the result was the establishment of the British Naval Mission in 1911. British Rear Admiral Lionel G. Tufnell was sent to assist and reorganize the Greek fleet. Additionally, ten Greek sublieutenants were sent to Britain for the purpose of attending gunnery, torpedo, and navigation courses The British First Sea lord, Prince Louis of Battenberg, openly supported Greek sea power and advocated the removal of British Naval Mission and calling the Ottoman navy hopeless. ${ }^{134}$

Greek leaders were not satisfied with the most capable and modern force in the eastern Mediterranean Sea. Additional purchases of warships indicate Greek intentions to expand into "Greater Hellena," or Anatolia proper. The precursor of such actions is echoed by D.J. Cassavetti in 1914. Cassavetti states the goal of Greek unification will not be complete until "Asia Minor falls under the control of Athens." 135 Greek warship orders still under construction at the outbreak of the Balkan Wars can be found in Table 7. The Greek naval additions complemented each other and provided for a maintainable balanced and workable force capable of sea control and power projecting. The Greek cruiser Averoff was capable of inflicting damage which could lead to the sinking of Ottoman capital ship but the Greeks possessed only one of this class. The close-aboard duel necessary to inflict such damage would be an unacceptable risk unless less

${ }^{134}$ Halpern, The Mediterranean Naval Situation, 324; and see Arhtur Jacob Marder, From The Dreadnought To Scapa Flow The Royal Navy In The Fisher Era 19041919 , Vol.I (London: Oxford University Press, 1961) 303.

135Ibid, $356-358$. 
TABLE 7

GREEK WARSHIP ORDERS

AT THE OUTBREAK OF THE BALKAN WARS

$\begin{array}{lllll}\text { Cruisers } & \text { Dimensions } & \text { Armaments } & \begin{array}{l}\text { Laid } \\ \text { Down }\end{array} & \begin{array}{l}\text { Nation } \\ \text { of Origin }\end{array} \\ \text { Antinauarkos Condouriotis" } & 446 \times 50 & 6-6^{\prime \prime} & 1911 & \text { England } \\ \text { Helle }^{\text {D }} & 322 \times 39 & 3-6^{\prime \prime} & 1910 & \text { USA }\end{array}$

\section{Battleships}

$\begin{array}{lllll}\text { Lorraine Class }^{\mathrm{c}} & 541 \times 881 / 2 & 10-13.4^{\prime \prime} & 1912 & \text { France } \\ \text { Salamis }^{\mathrm{d}} & 570 \times 82 & 8-14^{\prime \prime} & 1912 & \text { Germany }\end{array}$

aSeized while under construction in England in 1914. Renamed HMS Birkenherd. Note in Winston Churchill, The World Crisis, Vol. II (New York: Charles Scribner's Sons, 1923), 556.

'Laid down as Fei Hung for China. Purchased by Greece in 1914 while still at the New York shipbuilders. Note in Francis E. McMurtrie, ed. Jane's Fighting Ships, 1935 (New York: D. Van Nostrand Company, Inc.), 247.

${ }^{c}$ Cancelled upon outbreak of war by the French government.

${ }^{d}$ Laid down in Vulcan Yard at Stettin, Germany. Guns ordered from Bethlehem Steel Works, USA. Mr. Schwab of Bethlehem offered the sale of 14" guns ordered for Salamis to England. England purchased the Salamis order and placed the guns on monitors in July 1915. See Memorandum by Mr. Churchill, Chancellor of the Duchy of Lancaster, on the State of the Navy, May 1915, found in Winston S. Churchill, The World Crisis, Vol. II (New York: Charles Scribner's Sons, 1923), 554. 
expensive assets could be brought to bear in conjunction with the cruiser. Greek ship purchases provided such inexpensive assets.

All the ships acquired by the Greek navy from 1900 to 1912 possessed torpedo tubes. British-made Whitehead torpedoes provided the punch capable of sinking capital ships by inflicting damage below the armored belts. Torpedoes allowed less expensive assets to confront capital ships and thus not risk irreplaceable resources. The proliferation of torpedo-carrying ships neutralized the armor capital ships possessed. Torpedoe evolution along with mine warfare maturation, doomed existing capital ships. The cost of protection from torpedoes and mines financially prohibited retrofitting existing capital ships. .

By May 1912, the Balkan allies agreed to support each other in Macedonia and left the apportionment to a later date. Greece seems to have been content with the hope that areas inhabited with Greek nationals would become Greek. Venizelos anticipated only the full release of Crete along with the acquisition of several islands. In spite of apprehension on the part of Venizelos, the Balkan allies agreed to proceed. The timing of the war was influenced by four issues: Italy's success in North Africa, constitutional struggles in Istanbul, internal revolts in Albania, and the fear the Austria would seek compensation. Adding urgency to the situation, Austria had delivered a note on 13 August 1912 which requested the Ottomans decentralize their empire and allow a large, independent Albania. The fear of a large Albania encompassing territory coveted by Montenegro, Serbia, and Greece, and protected by Austria, prompted the Balkan allies 
to accelerate war preparations..$^{136}$

The Ottomans found themselves in a no-win situation. The German ambassador to Istanbul, Baron von Wangenheim, commented as follows: "If now the Powers advise the Turks to carry on with decentralization, it will be taken by the Albanians as an invitation to persist in their resistance. ${ }^{137}$ Yet instilling civil authority brought condemnation from the same Powers since reinstating central governmental control meant subduing Albanian, Bulgarian, Greek and Serbian Christians as well as revolting Muslims. The Great Powers--England, Russia, Germany, and Austria--presented a note requesting the Sublime Porte discuss reforms provided for in Article 23 of the Treaty of Berlin and the law of 1880 , which conformed to the expressed intention of implementing such reforms. ${ }^{138}$ The Ottoman government made an attempt to accommodate the request and stated that the matter would be presented to Parliament.

The Great Powers of Europe did little to promote peace in the regions around the Balkans. Italy was at war with the Ottomans and was shelling towns in Asia Minor and Arabia. France had seized Algeria and Tunisia and forced a protectorate in Lebanon. England had seized Egypt and attempted to force a protectorate over Kuwait. Austria had annexed Bosnia and Russia actively persecuted Muslims in the former Black Sea Ottoman territories. Russia also staffed the army of Montenegro. ${ }^{139}$ England had

$$
\begin{aligned}
& { }^{136} \text { Darkin, 194-195; Massey, 374-376. } \\
& { }^{137} \text { Dugdale, Vol. IV, } 111 . \\
& { }^{138} \text { Darkin, 134-135. } \\
& { }^{139} \text { Massey, } 377 .
\end{aligned}
$$


provided a naval mission to Greece and sold the very fleet necessary for a successful outcome against the Ottomans. The only Great Power not to prey upon Muslim territory was Germany and because of treaty obligations with Austria and Italy, Berlin could not intervene on behalf of Istanbul.

In order to ensure sea control, in September 1912 Venizelos requested from England and received an expert destroyer officer, Commander Cardale of the British Royal Navy. Cardale would be responsible for the training and planning of destroyer tactics and amphibious operations. In addition to Cardale, Engineer-Commander Watson of the British Royal Navy was sent to Athens to keep the Greek-owned, English-built fleet in working order. When hostilities had begun, England designated Admiral Kerr, of the British Royal Navy, as Commander of British Naval Mission - Greece, replacing Admiral Tuffnell. ${ }^{140}$ Tuffnell was on the Navy's retired list; however, Kerr reported straight from the active fleet.

The Greek navy mobilized on 1 October $1912 .{ }^{141}$ In response, the Ottoman government opted to demilitarize the Aegean island of Sisan and release fifty-five Greek merchant vessels anchored in the Sea of Marmara as a gesture of good will in the hope Greece would remain neutral. Ottoman military success depended upon transporting troops from Anatolia to Thrace, and the only Balkan country with a fleet capable of stopping such an operation was Greece. To further avoid a possible engagement, the

${ }^{140}$ Cassavetti, 33-35.

${ }^{141}$ Güleryüz, 19. 
Ottoman fleet was withdrawn to the Sea of Marmara. The Ottoman naval authorities, seeing that the release of interned Greek merchants ships had no positive influence on Greece, seized Greek registered ships still in the Sea of Marmara. Table 8 lists ships seized for the duration of the conflict on 16 October 1912.

In September, the timing of the war became critical. Public opinion in the Balkan nations clamored for war, regardless of the ethical or moral justification and more importantly peace talks with Italy began to mature, opening the fear of a quick settlement. Ottoman mobilization of forces on 29 September 1912 demanded quick action on the part of the Balkan allies because The Porte could mobilize forces sufficient to defeat the Balkan allies if given time. On 30 September 1912, the Balkan allies mobilized. ${ }^{142}$

On 12 October 1912, Bulgaria, in the name of the three Balkan allies, sent a note to the Sublime Porte demanding: ${ }^{143}$

- Proportional representation of ethnic groups in the Ottoman Parliament.

- Appointment of Christians to all public offices in Christian districts.

- Equality of Christian schools with Ottoman schools.

- No resettlement of Muslim refugees in Christian areas.

- Regional enlistment for military service; i.e., Christians in Christian companies.

${ }^{142}$ Dickinson, 310

${ }^{143}$ Anastasoff, $189-191$. 
TABLE 8

GREEK SHIPS SEIZED BY THE OTTOMANS, OCTOBER 1912

\section{$\underline{\text { Steamers }}$}

Harilos Trikopis

Asos Ramanos

Marella

Paxli

Ithaki

Cambridge

Kiyos

Manosis

Aryos

Asos

Anna

Iskalamanga

Leon Izavros

Sami

Nikolavus

Nikolaus Kostantinius

Katina

\section{Steamboats and Tugs}

Ayavar Vara

Zahala

Ospihi

Eftahiya

Yangilistria

Odesiye

Irini

Nikolaus

Express

Aya Andirya

Elli

Dimitriyos

Anna

Barbonitis

Kostantinos

Teofilos

Kostantinos (Padole)

Elias Eleni Elpis

Maryani

Matilli

Memo

Buyukdere

Obi

Istefano

Alpidofos

Source: Ahmet Güleryüz and Bernd Langensiepen, eds, trans. by James Cooper, The Ottoman Steam Navy 1828-1923 (Annapolis, MD: Naval Institute Press, 1996), 195. 
- Reorganization of gendarmerie under Swiss and Belgian organizers.

- A supreme council to be instituted with an equal number of Christians and Muslims to see that reforms were applied.

The Balkan Allies' demands had no merit because the issues in question had been achieved by the reconstitution of constitutional government in 1909. The Ottoman Parliament was representative of population; loyal Christians were appointed to governmental positions; schools were equal; Muslim refugees had not been resettled in Ottoman Europe since 1878; Christians could and did serve in the Ottoman army; gendarmeries had been reorganized with the assistance of France; and the Ottoman Parliament had overseen the progress of reforms.

The Ottoman government sent no answer to this note. The C.U.P. government stressed reforms and objected to foreign interference in the internal affairs of the Empire. With the war with Italy still unresolved, the Ottoman government hoped to settle the status of Tripolitania and Cyrenaica by placing a Muslim prince in control.

The Ottoman Grand Vizer, Kiamil Pasha, realized that command of the sea was imperative in order to win and initiated discussions with Greece over Crete. Kiamil was a holdover from the deposed Abdul Hamid's court and was a master of intrigue. Kiamil offered to release Crete from the Sultan's suzerainty and grant substantial privileges to the Greeks throughout the Empire if Greece disavowed Bulgaria and Serbia. This offer Greece refused. ${ }^{144}$ Before the Ottomans could conclude a peace treaty with Italy,

${ }^{144}$ Cassavetti, 11-12. 
Montenegro's King Nicholas (1910-1918) and the kingdom's Russian-staffed army declared war on 8 October 1912. ${ }^{145}$ The Porte, fearing being in the unenviable position of waging two wars at once, concluded a hasty agreement with Italy on 18 October 1912 at Lausanne, Switzerland. ${ }^{146}$

The status of the Ottoman naval assets compared to the Balkan allies can be found in Table 9. The disposition of Ottoman naval forces is found in Appendix 4.

TABLE 9

OTTOMAN NAVAL ASSETS COMPARED TO THOSE

OF THE BALKAN ALLIES, OCTOBER 1912

Type of Ship

Battleships

Cruisers

Destroyers

Torpedo Boats

Submarines
Ottoman Empire

3

6

6

21

0
Balkan Allies

3

1

15

30

2

Source: Fred T. Jane, ed. All the World's Fighting Ships, 1907/08 (London: Sampson Low Marston, 1909; reprint, New York: Arco Publishing Company, 1969), 403, 352$355,356,358$.

On paper, the forces appear even but the Greek navy, which comprised the bulk of the Allies' naval assets, was modern. The Greek forces were for the most part Englishbuilt and the enlisted men and officers were English-trained. The Greek commanders were utilizing assets with similar characteristics, capabilities, liabilities, and supply

${ }^{145}$ Massey, 377.

${ }^{146}$ Dakin, 195. 
needs. Also, Greek ships possessed radios that allowed over-the-horizon communication and intelligence. Ottoman naval units for the most part did not possess radios, forcing Ottoman units to employ visual identification and communication. The requirement of relying on visual identification and communication negated the larger caliber naval gun and the safety distance such weapons provided.

The German-built battleships Torgud Reis, Barbaros Hayreddin and the Schechau-built destroyers Demirhisar and Hamidabod were ready for action. Morale remained high in the fleet throughout the war, even with the scarcity of fuel and ammunition. The battleships looked impressive; however, the ships were too complicated and logistically were not up to European standards. Rangefinders and ammunition hoists were absent, telephones did not work, pump piping was corroded, watertight doors could not be closed, and the boilers needed extensive work.

Because of the lack of naval bulk transport, the Ottoman navy sequestered thirtythree freighters and thirty-eight tugs and steamboats in Istanbul's harbor. The Ottomans would also charter ships from the United States, Romania, and Austria in order to ferry supplies and troops. The use of such foreign-flagged vessels provided security of the registered ship's flag. Greek warships would fire only on one foreign-flagged ship during the conflict. Any inconvenience a foreign-flagged vessel may have caused to the war effort would be insignificant compared to the uproar of an international incident.

Foreign naval power immediately began to flex once the war began in earnest. Britain dispatched warships to Salonika to protect English ships, lives, and property. Germany sent the SMS Loreley to Salonika in order to return the ex-sultan Abdul Hamid 
to Istanbul. ${ }^{147}$ Foreign warships vacated Ottoman ports only if the fighting spread to the ship vicinity. The presence of foreign warships prevented large-caliber naval gunfire bombardment of Greek ports and facilities.

The only secure route for military supplies for the Ottomans was through Romania. The use of Romanian and Austrian flagged vessels insured delivery. However, supremacy in the Black Sea was never a question. Bulgaria possessed few naval assets that could challenge the Ottoman fleet. The Balkan allies utilized western European armament manufacturers, predominantly English and French, and had full use of Greek ports. Bulgaria utilized indigenous production of small arm ammunition with plants in Sofia. Importation of arms from Russia was minimal. Russia did not overtly want a conflict in the Balkans in 1912. The military upheavals originating from its defeat in the Russo-Japanese War, along with internal unrest, ruled out an adventurest foreign policy. Additionally, Russia did not desire any change of status for Istanbul unless the Dardanelles fell under Russian control.

The naval theaters of the Balkan War were the Ionian, Aegean, Black, Marmara, and Red seas.

The first battle for the Ionian coast took place in the Arta Gulf. The Ottoman navy's only assets were gunboats at Preveza, used in peacetime to combat smuggling. . On the opening day of the Balkan War, Greek torpedo boats under Captain Damianos of the Greek Royal Navy entered the Arta Gulf and caused the Ottoman gunboat Antaya and

${ }^{147}$ F.O. 46600/33672/12/44, No. 468, Goschen to Grey, Berlin, 1 November 1912. Gooch and Harold Temperley, Vol. IX, Part II, 73-74. 
motorboats No. 9 and No. 10 to be scuttled. Ottoman naval forces at Iskodia comprised of the steamer Gura, an old ex-Bosporus ferry; the lake steamers Iskodia and Kizomuyos; two motor boats, Filiyo and Kilsnya, purchased in 1912; and the steam pinnaces from the Mesudiye and Asar-i Tevfik. There were also a large number of civilian sailing craft and barges. Iskocha was attacked by Montenegran forces on 15 October 1912 but Iskodia did not fall after the initial attack. Political rivalry between Montenegro and Serbia spared the Scutar region until January 1913. Under Essad Pasha's leadership, Scutar and Iskodia held out until 23 April 1913.148

The naval assets at Selanik were commanded by Ottoman Capt. Aziz Mahmut Bey. The base was protected by four $210 \mathrm{~mm}$ shore batteries and two 24-mine barrages which had been laid prior to the war with Italy. Aziz Mahmut also was the commanding officer of the Fethi-i Bulend, a former steam corvette. At the outbreak of the Italo-Ottoman War, the crew and guns of the Feth-i Bulend were removed from the ship to augment the shore batteries. This gave Aziz Mahmut an additional four $150 \mathrm{~mm}$, four $75 \mathrm{~mm}$, and four $57 \mathrm{~mm}$ guns. Also at Aziz Mahmut's disposal were the tugs Surat, Teshilat, Katerin, and Selanik. The Selanik was fitted out as a minelayer, and all the tugs had a single $37 \mathrm{~mm}$ gun.

On 31 October 1912, the Greek torpedo boat No. 11 departed Leftehois for Selanik. It slipped past the searchlight batteries at Vardar and Karaburnu and the mine barrages. The Greek warship fired three torpedoes at the Feth-i Bulend. One ran wide

${ }^{148}$ Güleryüz, 20. 
and hit the coaling pier, causing serious damage, but the other two hit the target between the foremast and the funnel. The Feth-i Bulend capsized and sank with the loss of seven crew, including the ship's Iman.

The Greek forces surrounded Selanik, and the Ottoman garrison surrendered on 9 November. Before the garrison surrendered, Aziz Mahmut disarmed the Teshilat, Surat, and Selanik and transferred the ships to French registry. The Greek attack on a "French" ship led to an immediate protest from the French naval commanders present. The tugs left port under a French flag, and through the Greeks tried to delay the ships at Limni, the tugs made it to the Dardanelles. The three tugs changed registry again, back to the Ottoman registry.After the surrender of Selanik, the Greeks seized the royal yacht Fuad, which had been utilized as a hospital ship under the Red Crescent. The only Ottoman merchant ship lost to the enemy was the Trabzon which was attacked while underway from Ayvalik to Midilli, on 9 November 1912. ${ }^{149}$

The Greek commanders utilized the Greek registered vessels to ferry troops across the Atra Gulf to seize the province of Yanya. The use of the overwhelming waterborne transportation the Balkan Allies possessed enabled the rapid deployment of troops from Yanya and Salonika to Thrace.After the fall of Salonika on 9 November, a fleet of twenty-seven Greek transports was able to move an entire Bulgarian division east to Dedeagatch under the protection of a Greek squadron. At the same time, the Greek Admiral Kountouriotis established a base at Mudros Bay on the captured island of

is9 Ibid. 
Lemnos in order to entrap the Ottoman fleet should it appear in force at the opening of the Straits. ${ }^{150}$

The Black Sea operations witnessed the deployment of Ottoman warships in the roles of naval gunfire support and convoy duties. Naval gunfire support is imperative for troop transport in a combat theater and for landing on a hostile beach. The battleships Barbaros Hayreddin and Torgud Reis, along with the destroyers Muavent-i Milliye and Tasoz, shelled Bulgarian positions at Galata Burna on 19 October 1912. Further gunfire support roles for the battleships were limited due to the availability of targets and ammunition. The cruisers Hamidiye and Mecidiye, assisted by the destroyers Yadigar-i Millet and Numune-i Hamiyet, conducted gunfire support up and down the Bulgarian coast. With few exceptions, such as lack of ammunition or the inability to identify targets independent of friendly troops, the Ottoman naval gunfire support suppressed Bulgarians troop movements.

The readiness of ships capable of operations of some sort indicates that the morale of naval forces was excellent. The battleships and cruisers experienced boiler problems that restricted speed. However, the distance traversed and the Bulgarian naval opposition did not demand full speed.Readiness became paramount when the cruiser Hamidiye was torpedoed by the Bulgarian torpedo boat Stogi. The attack left the Hamidiye with a blast hole six feet square and a seam tear forty feet long. The crew reacted very well. Damage control parties began to stabilize the tear and seal the hole and 694).

150K.L. Rankin, "The Battle of Helles and Lemnos," Proceeding (May 1940, 693- 
pump crews diminished the flooding, and counterflooding righted the ship to an even keel. Speed during this casualty dropped to five knots. Considering the extent of the damage, five knots would have been maximum to prevent further structural damage. The reaction to the damage by the crew, along with the structural soundness of the ship, reflects well on the Ottoman navy. The ship was saved and was able to continue to fight even though severely damaged. ${ }^{151}$

Romania provided material support to the Ottomans throughout the war from the port of Constanza. Due to the lack of Ottoman registered ships, Romanian and Russian flagged bottoms along with Greek war prizes transported supplies. Greek control of the Aegean Sea lanes prohibited the landing of additional troops and supplies to Ottoman provinces in the Balkans. Where men and material did get through, Ottoman forces held their own. Table 10 shows the vessels chartered in September 1912 as troop transport in the Black Sea. The listed vessels, when not transporting troops, were utilized for other wartime needs such as colliers, bulk transport, civilian ferries, and dry cargo.

The Sea of Marmara naval action defended Istanbul and allowed for the utilization of naval gun fire support. The Bulgarians broke through to Gelibolu on 30 October 1912 but the Ottoman navy could not provide meaningful gunfire support until 6 November. This was because of the need for preventing the Greeks from forcing the Dardanelles, thus requiring a blocking force at Kaleh Sultaniyeh in addition to operations along the Bulgarian coast. Had the Greeks forced the Dardanelles into the Sea of

\footnotetext{
151Anastasoff, 192-193.
} 
TABLE 10

BLACK SEA TROOP TRANSPORTS, 1912

Name

On Temmus

Seyyar

Guzel Girit

Necat

Selamet

Kiyos

Kesendere

Aryos

Gulcemal

Marmara

Halep

Akdeniz

Mithat Pasa

Mahmut Sevket Pasa

Inebolu
Built (if known)

1891

1893

1891

1870

1853

1902

1874

1872

1881

1890

1901

1886

1888

\section{Tonnage}

$2132 \mathrm{gt}$

$3338 \mathrm{gt}$

$1232 \mathrm{gt}$

$1523 \mathrm{gt}$

$1692 \mathrm{gt}$

$540 \mathrm{gt}$

$438 \mathrm{gt}$

$510 \mathrm{gt}$

$5071 \mathrm{gt}$

$2472 \mathrm{gt}$

$3684 \mathrm{gt}$

$5062 \mathrm{gt}$

$4455 \mathrm{gt}$

$2690 \mathrm{gt}$

$233 \mathrm{gt}$

Source: Ahmet Güleryüz and Bernd Langensiepen, eds., trans. by James Cooper, The Ottoman Steam Navy 1828-1923 (Annapolis, MD: Naval Institute Press, 1994), 195.

Marmara, Istanbul would have been lost, failure to check the Bulgarians coming along the Black Sea could have jeopardize supply shipments from Romania.

Table 11 shows vessels chartered in September 1912 as troop transports in the Sea of Marmara. The listed vessels, when not transporting troops, were utilized for other wartime needs such as coalers, bulk transport, civilian ferries, and dry cargo.

The battleship Torgud Reis and the destroyer Basra began to provide gunfire support on 7 November. The cruisers Hamidiye and Mecidiye rushed from gunfire support along the Black Sea coast on 13 November. The gunfire support provided by the 
TABLE 11

SEA OF MARMARA TROOP TRANSPORTS, SEPTEMBER 1912

Name

Manosis

Bezm-i Alem

Heybeliada

Plevne

Edremit

Nimet

Nilufer

Iskalamanga

Baslangic

\section{Built (if known)}

1888

1873

1892

1887

1877

1890

1882

1852

\section{Tonnage}

$1363 \mathrm{gt}$

$4572 \mathrm{gt}$

$927 \mathrm{gt}$

$1154 \mathrm{gt}$

$414 \mathrm{gt}$

$310 \mathrm{gt}$

$1088 \mathrm{gt}$

$1591 \mathrm{gt}$

$381 \mathrm{gt}$

Source: Ahmet Güleryüz and Bernd Langensiepen, eds., trans. by James Cooper, The Ottoman Steam Navy 1828-1923 (Annapolis, MD: Naval Institute Press, 1996), 195.

warships had a minimal effect on the Bulgarians because forward observation needed to achieve accurate targeting was not available. Communications between ground forces and naval gunfire ships was non-existent. The lack of ammunition for the battleships hampered the use of the $280 \mathrm{~mm}$ guns, but the battleships' very presence dictated the route the Bulgarians used to assault the Catalca line. The Bulgarians avoided large troop concentrations within the effective range of the battleships' main guns of eight to twelve miles.

The Ottomans fell back to the Catalca line where a heroic stand prevented the loss of Istanbul. An armistice was agreed upon by the belligerents on 3 December 1912. The war for Ottoman Europe had been lost. The Sultan's forces held only Adrianople (Edirne), Janina (Yanya), Setari, and the area east of the Catalca line. At the insistence of 
the Balkan Allies, the armistice excluded Greece. Greece was occupying islands in the Aegean and had not completed the operation. Distrust that the Ottomans might transport troops from Asia precluded the allies from securing naval action in the Aegean while Greek transports were used to ferry Bulgarian forces from Salonika to Chios and from Salonika to Piraeus.

The conflict in the Aegean began in earnest on 20 October 1912 and would continue through the First and Second Balkan Wars until the cease fire of 30 May 1913. A map of the Aegean Sea is found in Appendix 5.

On 20 October, Greece notified the foreign powers of a blockade of the Ottoman coast. The chief object of the Greek navy was to bottle up the Ottoman navy in the Dardanelles in order to seize islands in the Aegean and prevent follow-on forces from Asia and Anatolia. Greek seizures of major Ottoman Aegean islands are found in Table 12.

On 26 November $1912 \mathrm{Mr}$. Gerald H. Fitzmaurice, Chief Dragoman of the British Embassy at Istanbul, discussed privately with Jemil Pasha, Prefect and Vali of Istanbul, the naval situation. Jemil Pasha offered to have the Sultan cede Egypt to Britain in exchange for English help in stopping the Balkan Allies' advance on Istanbul. ${ }^{152}$ Britain declined the offer, leaving the Ottomans without a meaningful naval presence in the Aegean. The lack of opposition allowed the Greeks to seize territory deemed "Greater Hellena." The British Consul-General in Cairo, Lord Kitchner of Khartum,

152F.O. 51112/42842/12/44, No. 1000, Fitzmaurice to Corey, Istanbul, 26 November 1912. In Gooch, Vol. IX, Part II, 210. 
TABLE 12

GREEK SEIZURES OF MAJOR OTTOMAN AEGEAN ISLANDS

$\begin{array}{ll}\text { Name of Island } & \text { Date Seized } \\ \text { Imroz } & \text { 20 October } 1912 \\ \text { Boca Ada } & \text { 20 October } 1912 \\ \text { Lemnos } & \text { 21 October } 1912 \\ \text { Mitylene } & 21 \text { October } 1912 \\ \text { Tenedos } & 21 \text { October } 1912 \\ \text { Thasos } & 31 \text { October } 1912 \\ \text { Strati } & \text { 31 October } 1912 \\ \text { Imbros } & \text { 31 October } 1912 \\ \text { Samothrace } & \text { 1 November } 1912 \\ \text { Psara } & \text { 4 November } 1912 \\ \text { Icaria } & \text { 17 November } 1912 \\ \text { Lesbos } & \text { 21 November } 1912 \\ \text { Chios } & \text { 24 November } 1912 \\ \text { Samos } & \text { 11 April } 1913\end{array}$

Source: F.O. 45625/43461/12/44, No. 78, Grey to Kitchner, London, 29 October 1912. Found in G.P. Gooch and Harold Temperly, eds., British Documents on the Origins of the War 1898-1914, Vol. IV, Part II (London: His Majesty's Stationery Office, 1934), 59.

fearing Muslim sentiment towards defending the Sultan and Islam, decided that Egyptians' neutrality should be followed up with the complete expulsion of Ottoman influence in Egypt and the Sudan. Kitchner tried to suppress any expression of Muslim support for the Ottoman cause. ${ }^{153}$

The Thrace theater stabilized in December 1912, and Ottoman naval action against the Greek fleet operating in the Aegean Sea began. On 14 December, the

${ }^{153}$ F.O. 45625/43461/12/44, No. 78, Grey to Kitchner, London, 29 October 1912. In Gooch, Vol. IX, Part II, 59. 
Ottoman fleet, reconfigured into an armored ship division, two destroyer divisions, and an independent operational unit, began to pursue the Greeks in and around the Dardanelles. Table 13 shows the fleet organization after 20 December 1912. Ottoman RADM Ramiz Naman Bey was an aggressive sailor, but insuffeient material support hampered operation tempo. The morale of the sailors was excellent, and the fleet performed well considering the scarcity of anmunition and fuel.

The Ottoman cruiser Mecidiye entered the Aegean Sea on 14 December 1912 in order to duel with the Greek cruiser Averoff. The Greeks responded by rushing at the Mecidiye with destroyers. This action, the frenzied attack with destroyers and torpedo boats, was a precursor of future Greek tactics. The Ottoman navy, divided in order to protect convoys in the Black Sea and to provide gunfire support at the Catalca line, now had to meet a numerically superior force. The key to any Ottoman victory lay in a defensive strategy using shore batteries in conjunction with naval units.

The Battle of Helles commenced on 16 December 1914 and became the first major sea battle since Tsushima. On paper, the opposing sides were relatively balanced. Greek forces included the Averoff, R.G.S. Hydra, R.G.S. Psara, and R.G.S. Spetsai. Ottoman forces were made up of the Barbaros Hayreddin, Torgud Reis, Mesudiye, and Asar-i Tevfik. Greek Admiral Kountouriotis had his flag on the Averoff and Ottoman Admiral Ramiz on the Barbaros Hayreddin. At 08:30 the Ottoman fleet sortied out the Straits past Cape Helles on a track of west by north. The Greek fleet responded with a converging course from Lemnos, and at 09:22, while 12,000 meters apart, the Ottomans opened fire. Greek forces returned fire, resulting in the Mesudiye receiving three hits and 
TABLE 13

OTTOMAN FLEET ORGANIZATION, 20 DECEMBER 1912

Armored Division - Commanding Officer Rear Admiral Ramiz

Barbaros Hayreddin

Torgud Reis

Mesudiye

Demirhisar

Sivrihisar

Sultanhisar

Hamidabad

Resit Pasa (hospital ship)

Destroyer Division I - Commanding Officer Captain Huseyin Rauf

Mecidiye

Muavent-i Milliye

Gayret-i Vataniye

Nuhmune-i Hamiyet

Destroyer Division II - Commanding Officer Commander Hakki Esref

Berk-i Satvet Tasoz

Yarhisar

Basra

Operational Division III - Commanding Officer Captain Ismail

Asar-i Tevfik (destroyer)

Samsum (destroyer)

Tirimujgan (workshop ship)

Inibah (salvage tug)

Samsum (tug)

Source: Ahmet Güleryüz and Bernd Langensiepen, eds., trans. by James Cooper, The Ottoman Steam Navy 1828-1923 (Annapolis, MD: Naval Institute Press, 1996), 196. 
falling out of line (see Appendix 6).

Kountouriotis took advantage of $A$ veroff $f^{\prime}$ superior speed and engaged the Ottoman line independently, while the Hydra, Psara, and Spetsai turned south on a parallel course with the Ottoman fleet. The independent action of the Averoff, along with the parallel passing engagement necessitated by the older Greek ships, forced Ramiz to fall back to the Dardanelles. By 10:50, the Averoff had closed within 3,000 meters and scored seven hits on the Barbaros Hayreddin. The Ottoman ships retreated in bad order, and Greek pursuit was only stopped when shore batteries began to weigh in. ${ }^{154}$

The battle illustrates the dominant view of naval warfare in the early twentieth century: battleships slugging it out to determine the winner. Since no decisive blow was struck, the battle was a draw. The smaller warships, destroyers, torpedo boats, cruisers, and submarines played no role in this action. The Greeks possessed and had in theater smaller assets that could have delivered torpedos capable of sinking Ottoman battleships. The Ottomans had destroyers along with the cruisers Hamidiye and Mecidiye, but for unknown reasons they did not bring the ships out to fight. The addition of the two Ottoman cruisers could have tipped the scales in Ramiz's favor, for the Greeks had no assets capable of dueling with the two ships. The Ottoman fleet set an example of courage and determination in a time of few successes on the battlefield and political tension in Istanbul. This was also the first time since 1877 that the fleet had seen ship-to-ship combat. In most battles with the Greeks, the Ottomans enjoyed parity, but not

\footnotetext{
${ }^{154}$ Rankin, 697.
} 
supremacy.

The first submarine torpedo attack in naval history occurred on 22 December 1912. The Ottoman cruisers Mecidiye and the Berk-i Satvet were dueling with six Greek destroyers when the Greek submarine Dolphin launched a torpedo at the Mecidiye. The torpedo, launched beyond the effective range meters, missed. The action of the Mecidiye, turning into the torpedo, decreasing range, and bearing between the submarine and target, would be the preferred method of anti-submarine warfare in the coming wars.

Decreasing range and bearing increased the odds the torpedo would miss. Also, since a torpedo must travel a pre-set distance before arming, decreasing that distance might reduce the odds of the warhead becoming armed.

Ottoman fleet operations against Greek units became difficult due to logistics. Fuel and ammunition was increasingly in short supply and yet, when the chance arose, Ottoman forces picked opportune times to engage the Greeks. By choosing the time and place to engage, Ottoman forces utilized what resources were available for possible maximum benefit. This logistically driven tempo served also to delay the Ottoman ships' wear and tear. The pressing need for naval gunfire support at the Catalca line along with combating Greek forces limited availability of the battleships and cruisers .

The relationship between the Ottoman army and navy was not amicable. Strategy for the Ottoman navy was not clear, indicating divided directives. Army demands to retake lost islands and transport troops lacked planning and coordination. An army plan to retake the island of Bozca Ada failed due to lack of communication because the troops assigned to the assault were not notified, and thus they were not in place for 
embarkation. ${ }^{155}$ Ottoman naval commanders had serious doubts about the army's logistically mounting a landing. Naval planners also had concerns that there were no naval gunfire platforms available to protect such a landing. The balance of power in the Aegean dictated the Ottoman use of every available platform to confront Greek offensive action.

The last major action in the Aegean came on 18 January 1913, the Battle of Lemnos. Commanding the Ottoman forces was Admiral Ramiz, who wanted to pull the Greeks into a decisive battle. The plan was to advance towards Limanli and seek contact with the Averoff, forcing the decisive battle envisioned by Mahan, and get a "...definite conclusion with Greeks." ${ }^{156}$

The Ottoman fleet left the Dardanelles at 0820 hours on course 253 and sped at eleven knots. The flagship Barbaros Hayreddin led with the Mecidiye, Torgud Reis, Berk-i Satvet, Basra, and Yarhisar in a spearhead formation. The fleet tugs Samsum and Intibah stood ready to assist in salvage operations.

Since September 1912 the Greeks had maintained a guard ship at the mouth of the Dardanelles in order to reconnoiter Ottoman fleet movements. The Greek destroyer Leon, along with the torpedo boat Aspis, radioed the Ottoman sortie and the Greeks responded with the cruiser Averoff, Hydra, and Psara, along with five destroyers. Admiral Kountouriotis was commanding officer with the Averoff flagship. The opening

${ }^{155}$ Güleryüz, 22-23.

${ }^{156}$ F.O. 2653/1/13/44, No. 28, Lowther to Grey, Istanbul, 17 January 1913. In Gooch, Vol. IX, Part II, 421. 
salvo came from the Barbaros Hayreddin at 1155 hours at a range of 8,000 meters. Tactics dictated use of the superior gunfire range of the battleship. The $280 \mathrm{~mm}$ shells blanketed the Averoff. The Averoff, armed with $240 \mathrm{~mm}$ guns, held fire in order to reduce range and increase accuratcy. Once in range, the two forces proceeded south, dueling port to starboard. The Ottoman battleship Mesudiye received numerous hits, reducing her speed and thus pulling the ship out of line (see Appendix 7).

The ensuing battle witnessed the Greeks' attempt at naval maneuver called "crossing the T." This is when one force comes across the course of the opposing force. This allows one force to bring broadsides to bear upon the opposing force, which is left with only the front gun mounts to bear. The Russian squadron was destroyed by Japanese Admiral Togo at the Tsushima Straits on 14 May 1905 using this maneuver. ${ }^{157}$ The Greek maneuver failed when the Ottomans altered course north, however, the Greeks did hit the Mesudiye on the front 150mm gun mount and the Barbaros Hayreddin on the center $280 \mathrm{~mm}$ turret. Hits to the Barbaros Hayreddin's superstructure caused fires that forced the ship to slow to five knots. The engagement broke off when the Greek fleet passed into range of the shore batteries at Kumkale. ${ }^{158}$ The damage to the two ships destroyed any hope of regaining command of the Aegean Sea for the Ottomans during the First Balkan War. ${ }^{159}$ 1976), 91.

${ }^{157}$ S.G. Gorshkov, The Sea Power of the State (Annapolis: Naval Institute Press, ${ }^{158}$ Rankin, 699.

${ }^{159}$ F.O. 2808/8/13/44, No. 32. Lowther to Elliot, Istanbul, 19 January 1913. In Gooch, Vol. IX, Part II, 430. 
Greek destroyers, torpedo boats, and submarines played no role in the actual battle except to provide early warning of the Ottoman sortie. Athens had demanded the warships from the builders ahead of schedule, and time did not allow for delivery of the required size of torpedo. The Ottoman destroyers and torpedo boats had ordnance but they were not utilized. After the Balkan wars were over,Ramiz would be replaced, courtmartialed, and retired. ${ }^{160}$ Further surface action was sporadic and led to few exchanges. The Ottoman army proposed landings on Midilli and Sakis but because of the uncertainty of the Averoff, the attempt was dropped. Surface action tapered off until the peace agreement was signed on 30 May 1913.

Red Sea operations were conducted by the Hamidiye on an extended deployment that began on 13 January 1913 and lasted till 7 September 1913. ${ }^{161}$ The commanding officer of the Hamidiye was the Ottoman Capt. Hussin Rauf. Rauf would later head up the planning department that would oversee the capital ship construction in Britain. ${ }^{162}$ As a young man, Rauf joined the C.U.P, and remained politically active during his military career. After the wars, Rauf would embark on a career that would last until his death on 16 September 1964.

The Hamidiye embarked upon the cruise with the attempt to entrap the Averoff. Having just been repaired from the Bulgarian torpedo attack, the cruiser was in fine shape but would experience radio problems the entire journey. Plans called for the Hamidiye to

${ }^{160}$ Rankin, 697.

${ }^{161}$ Dakin, 197.

${ }^{162}$ Güleryüz, 25-26. 
raid commercial vessels and island villages until the Averoff left the Dardanelles.

Removing the Greek cruiser would open the Aegean to Ottoman warships. Greek

Admiral Kountouriotis refused to withdraw the Averoff, owing to the danger of undetered Ottoman seapower, and the plan failed. ${ }^{163}$

The Hamidiye sank the Greek auxiliary Makedonia in Sira on 15 January before recoaling in Beirut and Port Said. The British government refused to allow Rauf enough coal to raid the Greek islands actively, so the Hamidiye passed through the Suez Canal to the Red Sea and showed the flag off Arabia. Hamidiye's action brought foreign power involvement and Great Britain and Italy shortly afterwards each sent two ships to Besika Bay, arriving on 28 January. France also sent one ship to Smyrna and another to Salonika to be held in readiness if required. The British warships HMS King Edward and HMS Zealandia arrived in Besika Bay on 28 January 1913. The exact mission the dispatched ships is not clear. The cruise of the Hamidiye and the success of the ship's raids bolstered the Ottoman spirit. The belief that the Hamidiye could tilt peace negotiations in favor of the Ottomans concerned the Great Powers. The war fronts had stabilized everywhere except in the Aegean Sea. ${ }^{164}$

The dispute as to the future of the Aegean islands of Thasos and Samothrace began to surface. Bulgarian Foreign Minister Dr. Daneff began voicing Bulgarian views that if the Ottomans were allowed any islands, Bulgaria should receive Thasos and Samo-

${ }^{163}$ Cassavetti, 53; Güleryüz, 26-27.

${ }^{164}$ F.O. 3711/3535/13/44, No. 56, Grey to Lowther, London, 25 January 1913. In Gooch, Vol. IX, Part II, 447. 
thrace. Greek expansion plans included both islands. ${ }^{165}$ The Hamidiye foray also created questions regarding the Italian occupied South Sporades, or Dodecanese, islands. The Italo-Ottoman peace treaty required Italy to evacuate the islands once Ottoman troops were removed from Tripolitania. Italy requested English assistance in awarding the islands to Greece and not retroceding Mitylene, Chios and Samos back to the Ottoman government. Italy feared France might acquire the islands for a forward naval base, placing the Italian commercial trade with the Levant in jeopardy. Sir Edward Grey, British Secretary of State for Foreign Affairs, suggested the Italian and Greek ambassadors sound their opinions in London "...if it could be done without giving guarantees to Turkey." 166 Italy would not relinquish control of the Dodecanese islands and would ultmately receive sovereignty with the Pact of London on 26 April $1915 .{ }^{167}$ In February 1913 Rauf returned to the Mediterranean and pursued coal for Hamidiye's bunkers. Rauf acquired coal at Beirut from the Hejaz Railway and made for the Albanian coast. The cruiser shelled the Greek training camp at Durazzo and attacked a Greek convoy at Singin, damaging six vessels on 12 March 1913. Low on fuel, the cruiser headed to Alexandria, but British officials blocked coal purchases. Hamidiye passed through the Suez Canal again and by 6 April 1913 visited at Cidde, Yemen.

165F.O. 534/106/13/44, No. 2, Grey to Bax-Ironside, London, 3 January 1913. In Gooch, Vol. IX, Part II, 249.

${ }^{166}$ F.O. 2209/106/44, No. 15, Grey to Rodd, London, 13 January 1913. n Gooch, Vol. IX, Part II, 403.

${ }^{167}$ A copy of the Pact of London is found in Elliot Grinnell Mears, Modern Turkey (New York: The MacMillan Company, 1924), 612-613. 
Hamidiye's stayed in the Red Sea until the cease fire came into force on 30 May 1913.

The ship would return to Istanbul on 7 September 1913 after an eight-month cruise. The fact the ship embarked upon the deployment so soon after the battle damage is a testament to the professionalism of the crew. The hurdles Rauf overcame, such as fuel, ammunition, and British reluctance, gives proof of the ingenuity of the Hamidiye's officer corps.

The new year witnessed the Ottoman government accepting the European territories as lost. By 23 January the general sense in the Porte favored a peaceful solution but a coup brought Enver Pasha to power when Osm Nizami Pasha, Minister of War, and two others were shot dead during a cabinet meeting. Mashmoud Shefket became Grand Vizier, Mehmed Izzet Pasha, Minister of War, and Talaat Bey, Minister of the Interior. Enver claimed the action was instigated by the army defending the Catalca line and the new cabinet took a hard line of continuation of the war. ${ }^{168}$

The Second Balkan War (3 February to 30 May 1913) found the Ottomans stalemated on the ground and lacking logistically on the water. In February Enver Pasha ordered landings at Sorkoy in order to relieve pressure on the Catalca front. The operational commander, General Ahmet Izzet, had reservations as to the timing of the landing. Despite concerns, Izzet assembled two divisions of the X Army Corps at Izmit and Bandirma. The navy chartered twelve ferries as transports and provided naval gunfire support, but the entire operation was covered in Istanbul's foreign language

168F.O. 3535/3535/13/44, No. 39, Lowther to Grey, Istanbul, 23 January 1913. In Gooch, Vol. IX, Part I, 438. 
papers, and the element of surprise was lost. ${ }^{169}$ On 8 February and 9 February, the $\mathrm{X}$ Army Corps landed at Sorkoy. The landings, over pontoon bridges, met little resistance at first, but Bulgarian counterattacks forced the X Army Corps back to the beaches. The situation around Gelibolu had deteriorated and the redeployment of troops from Gelibolu in order to conduct Enver's Sorkoy landing threatened to collapse the front, opening up Istanbul to the Bulgarians. Table 14 shows ammunition consumption during the Sarkoy landings of 8-11 February 1913. The numbers indicate the lack of resistance in the initial landing zone. The large $280 \mathrm{~mm}$ guns of the Barbaro Hayreddin and the Torgud Reis were not fired.

The Ottoman navy used some destroyers in the landings at Sarkoy. This use of shallow-draft destroyers in the amphibious role of troop transport provided naval gunfire support close aboard. The rapid delivery of troops via destroyers in a landing zone were the first use of such vessels in an amphibious operation. The Japanese would repeat such operations in the battle to retake Guadalcanal thirty years later. ${ }^{170}$ The Ottomans also utilized French-built Deperdussin monoplanes in the role of aerial observation, gunfire correction, and intelligence. Such information, interpreted correctly, allowed for the successful defense of Istanbul. French, English and German citizens flew under contract to the Ottoman "Administration for War Flying." 171 Additional landings at Sorkoy failed

${ }^{160}$ Güleryüz, 25.

170John Costello, Pacific War, 1941-1945 (New York: Rawson Wade, 1981), 330331.

${ }^{11}$ Lee Kennett, The First Air War, 1914-1918 (New York: The Free Press, 1991), 19; and Brian P. Flanagan, "The History of the Ottoman Air Force in the Great War," 
TABLE 14

AMMUNITION CONSUMPTION DURING THE SARKOY LANDINGS

\begin{tabular}{|c|c|c|c|c|}
\hline & $150 \mathrm{~mm}$ & $120 \mathrm{~mm}$ & $105 \mathrm{~mm}$ & $88 \mathrm{~mm}$ \\
\hline Barbaros Hayreddin & _- & -. & 250 & 180 \\
\hline Torgud Reis & 22 & 156 & -- & -- \\
\hline Berk-i Satvet & -- & -- & 84 & .. \\
\hline
\end{tabular}

Source: Ahmet Güleryüz and Bernd Langensiepen, eds., trans. by James Cooper, The Ottoman Steam Navy 1828-1923 (Annapolis, MD: Naval Institute Press, 1996), 196.

because the Ottoman navy was not informed of the landings. The operational tempo of the Ottoman fleet in the Sea of Marmara wound down to just patrols of the gunboats Musul and Drac. Supply difficulties dictated that Aegean operations get priority. The Ottomans could not afford to allow Greece uncontested access to the Greek populated Anatolian coast.

The battle of the Catalca line and the specter of the Bulgarian forces seizing Istanbul stirred the Great Powers to action. Bulgaria had reneged on accepting the Enos to Medea line, a proposal Sofia put forth in November $1912 .{ }^{172}$ Fear that Bulgaria would capture Istanbul spurred the Russians to advocate a naval force to "protect" Christians from retreating Ottoman forces or advancing Bulgarian troops. There was no need for such action except to create a pretense to invade. Western European powers began to station ships at Besika Bay on the Aegean side of the Dardanelles while Russian ships

Cross and Cockade Journal, XI (Summer-Winter 1970), 98, 119, 103.

${ }^{172}$ F.O. $47049 / 42842 / 12 / 44$, No. 412, Buchanan to Grey, St. Petersburg, 5 November 1912. In Gooch, Vol. IX, Part I, 99. 
loitered outside of the Bosphorus. Russia had raised objections to Bulgarian advances upon Istanbul in November 1912. ${ }^{173}$ With the resumption of fighting around Istanbul during the Second Balkan War, Russia again warned Bulgaria not to enter the city. ${ }^{174}$

The Bulgarians were not the only Balkan ally that worried the Great Powers. King Nicholas of Montenegro refused to end the siege of Scutari in Albania. Nicholas wanted financial compensation from Russia or Austria for not taking Scuarti. Scutari had been assigned to Albania by the Great Powers, and Austria and Italy agreed Albania should be secure within the agreed borders and resented the extortion.In addition to Montenegro aggression in Albania, Greece desired to seize the southern Albanian coast adjacent to Corfu and to accomplish the subjection, eighteen Greek transports with 11,000 Serbian troops sailed from Salonika. ${ }^{175}$

In order to get the Balkan Allies to respect Albanian borders, Sir Edward Grey proposed a naval demonstration in Montegrin waters. The King Edward and HMS Dartmouth were dispatched to Antivari, Corfu, to be joined by the German cruiser SMS Breslau, along with French, Austrian and Italian warships. With the fleet assembled, British VADM, Sir Cecil Burney, in conjunction with the other Powers' military representatives, issued an ultimatum to Montenegro to abide by the Great Powers' wishes II, 103.

${ }^{173}$ Sir A. Nicolson to Sir G. Buchanan, 5 November 1912. In Gooch, Vol. IX, Part

${ }^{174}$ F.O. 14865/9564/13/44, No. 84, Grey to Bax-Ironside, London, 28 March 1913. In Gooch, Vol. IX, Part I, 619.

${ }^{175}$ German Ambassador Jagow to Prince von Lichnowsky, 15 March 1913, found in Dugdale, Vol. IV, 167. 
over Albania. ${ }^{176}$ The ultimatum would go into effect in six hours and would result in Montenegran waters being blockaded unless Nicholas ceased the assault on Scutari. For political reasons in France, the deadline was relaxed to 10 April.

Greek Prime Minister Venizelos, not wanting to become a target of a military blockade, suggested to Sir F. Elliot that Greek ships en route to Albania with Serbian troops be prevented from landing. Greece had to abide by the Balkan Treaty and support Montenegro by assistin with troop movements, but Greece did not want to see a war with a Great Power over Scutari. ${ }^{177}$ On the night of 22 April, Essad Pasha, the commander of the Ottoman forces defending Scutari, surrendered after taking a Montenegran bribe and the prospect of becoming King of Albania. ${ }^{178}$ From Nicholas, Essad received generous terms for surrender, allowing the Ottomans to keep field guns, ammunition, and supplies, and march out with colors raised. The scheme was for Essad to be proclaimed Prince of Albania under the suzerainty of the Sultan and then cede Scutari to Montenegro. ${ }^{179}$ The fear of Austria moving against Montenegro and the complete abandonment of the Balkan Allies encouraged Nicholas to leave Scutari by 5 May 1913. ${ }^{180}$ Essad's actions seem

${ }^{176}$ F.O. 15752/15876/13/44, Enclosure, Admiralty to Foreign Office, London, 5 April 1913. In Gooch, Vol. IX, Part I, 656.

${ }^{177}$ F.O. 15756/13/44, No. 48, Elliot to Grey, Athens, 6 April 1913. In Gooch, Vol. IX, Part I, 657.

${ }^{178}$ Albertini, 443.

${ }^{179}$ F.O. 19807/135/13/44, Count de Salis to Grey, Cettinje, 29 April 1913. In Gooch, Vol. IX, Part I, 734.

${ }^{180}$ F.O. 20974/135/13/44, No. 151, Grey to Goschen, London, 5 May 1913. In Gooch, Vol. IX, Part I, 772; and Dugdale, Vol. IV, 176. 
ignoble and selfish, but the surrender left a Muslim army intact in Albania, preventing the total dismemberment of the country, and perhaps preventing the wholesale slaughter of Muslims witnessed in other theaters of action once Moslem military power became impotent.

Peace agreements came quickly once an armistice was concluded on 20 April 1913. The armistice did not include Montenegro because of the Albanian situation. The final agreement, the Treaty of London, signed 30 May 1913, brought the war between the Balkan Allies and the Ottoman Empire to a close. The Ottomans lost all the Aegean islands to Greece and Bulgaria. This demand was hotly denounced by Mahmud Sherket Pasha, the Ottoman Grand Vizier. The islands were indispensable in order to protect the Dardanelles and Anatolia. The Ottomans also lost all European territories west of the Enos-Midia line and any influence in Crete.

The Second Balkan War was still being contested when Greece and Serbia agreed to support each other diplomatically, and if need be militarily, in order to extract border concessions from Bulgaria. The agreement, signed 22 April 1913, followed concerns about Bulgarian claims on lost Ottoman territories. ${ }^{181}$ The Treaty of London, signed 30 May 1913, forced the Ottomans to cede territory to the victors, however, the victors did not trust each other enough to allow the Russian Czar to mediate the disputed territory. The mediation clause did not include Greece, leaving that portion of Macedonia occupied by Greek forces unresolved.

${ }^{131}$ A copy of treaty can be found in Gooch, Vol. IX, Part II, 1019-1021. 
The first week after the First and Second Balkan Wars were officially ended, the Bulgarians fired upon the Greek cruiser Averoff while the cruiser was sailing off the coast towards Salonika. ${ }^{182}$ The Bulgarian batteries had been brought up towards Salonika during the lull leading up to the London negotiations. Greece anticipated such aggressive actions from Bulgaria, resulting in the agreement of 22 April with Serbia. Greece approached the Ottomans about Bulgaria, but discussions with Greece were halted when the Ottoman Grand Vizier, Mahmud Sherket Pasha, and his naval aide-de-camp, Captain Ibrahim Pasha, were killed when unknown persons fired at their car on 12 June 1913. The Egyptian prince Said Halim Pasha became Grand Vizier on 13 June, and talks with Greece were never resumed. ${ }^{183}$

Bulgaria had become brazen enough in its territorial demands in such a manner as to alienate former allies Greece and Serbia. The Ottoman political scene was fluid, with a power grab involving elements in the army. Italy did not wish to surrender the Aegean islands as agreed to in the Treaty of Lausanne and Bulgaria wanted to claim those islands as a territorial concession from the Ottomans. Surrendering those islands to the Ottomans jeopardized Italian ambitions in Asia Minor. It would place another international player in the Aegean theater--Bulgaria--and also interfere with Greek expansion, which included the Dodecanese. ${ }^{184}$ The issue of the islands concerned Greece intensely. The islands of

${ }^{182}$ Cassavetti, 317.

${ }^{183}$ F.O. 27102/26816/13/44, Nicolson to Grey, Istanbul, 13 June 1913. In Gooch, Vol. IX, Part II, 841.

${ }^{184}$ F.O. 25532/9564/13/44, No. 118, Grey to Cartwright, London, 30 May 1913. In Gooch, Vol. IX, Part I, 825. 
Tenedos and Imbros could return to Ottoman control, where Thasos might go to Bulgaria. If another power received the Dodecanese, Greeks who inhabited the islands in question might never be united with Athens.

In all aspects, the naval war was over. In the subsequent war, Ottoman and Greek naval forces did not collaborate on operations. The speed of the war did not necessitate naval landings or naval gunfired support. Ottoman naval losses for the First and Second Balkan Wars can be found in Table 15 .

The Third Balkan War began in earnest on 29 June 1913 when Bulgarian General Savoff attacked the Greeks at Radovista and the Serbians at Gevgeli in Macedonia. The timing of the attack and the positions attacked--a salient between the Greeks and the Serbian forces--was chosen to separate the opposing forces. ${ }^{185}$ In the face of Savoff's attack, Greece and Serbia moved quickly into the offensive. Greece announced that a state of war existed but did not decline war. Romania mobilized on 3 July 1913 and on July 8 , Serbia declared war against Bulgaria. ${ }^{186}$ Romania launched an attack on Bulgaria on 11 July. ${ }^{187}$

On 1 July the Greeks overcame the Bulgarian garrison in the region of Thessalonika and advanced to occupy Drama, Serres, and Kavala. On 8 July following

${ }^{185}$ Cassavetti, 318-319.

${ }^{186}$ Mears, 588; and Sir H.O. Bax-Ironside to Sir A. Nicolson, 30 June 1913. In Gooch, Vol. IX, Part II, 876.

${ }^{187}$ Sir H. Bax-Ironside to Sir A. Nicolson, 11 July 1913. In Gooch, Vol. IX, Part II, 905 . 
TABLE 15

\section{OTTOMAN NAVAL LOSSES -}

\section{FIRST AND SECOND BALKAN WARS}

\section{December 1912}

$\begin{array}{lll} & \text { Killed } & \text { Wounded } \\ \text { Barbaros Hayreddin } & 7 & 14 \\ \text { Torgud Reis } & 8 & 20 \\ \begin{array}{l}\text { Mesudiye } \\ \text { Antalya }\end{array} & 3 & 7 \\ \text { TOTAL } & 7 & -- \\ \text { 18 January 1913 } & 25 & 41 \\ & & \\ \text { Barboros Hayderrin } & & 55 \\ \text { Torgud Reiss } & 32 & 49 \\ \text { TOTAL } & 9 & 104 \\ & 41 & \\ & & \\ \text { Name } & \text { Ottoman Tonnage Loss as of 30 May } 1913 \\ \text { Feth-i Bulend } & \text { Tonnage } & \text { Date } \\ \text { Antalya } & & 31 \text { October } 1912 \\ \text { Trabzon } & 2762 \mathrm{gt} & 31 \text { October } 1912 \\ \text { No. } 9 \text { Gunboat } & 165 \mathrm{gt} & 9 \text { November } 1912 \\ \text { No. 10 Gunboat } & 70 \mathrm{gt} & 31 \text { October } 1912 \\ \text { Asar-i Tevfik } & 20 \mathrm{gt} & 31 \text { October } 1912 \\ \text { TOTAL } & 20 \mathrm{gt} & 12 \text { February } 1913 \\ & 4687 \mathrm{gt} & \end{array}$

Source: Ahmed Güleryüz and Bernd Langensiepen, eds., trans. by James Cooper, The Ottoman Steam Navy 1828-1923 (Annapolis, MD: Naval Institute Press, 1996), 196, 18 27. 
their victory at Bregalnetsa, the Serbs entered Ishtip. On 11 July Romania occupied the Dobrudja quadrilateral without opposition. From the beginning of this war, Bulgaria had voiced a desire for an armistice. King Ferdinand of Bulgaria contended that Savoff acted without approval, a statement later proven false. ${ }^{188}$ Since April there had been numerous frontier incidents between Greek and Bulgarian troops and the creation of a neutral zone did not prevent altercations. The reports of Bulgarian atrocities soon proved true, and Greek propaganda fanned emotions against their former ally. The Bulgarians committed murder, rapes, and forced conversion to exarchate Christianity for both Muslims and patriarchists, and ethnic cleansing of non-Bulgarians. The removal of non-Bulgarian civilians and the refugee crisis it created was instrumental in the swift defeat of Ottoman forces in Thrace. The Bulgarians began to use the same tactics on Greeks and Serbians in disputed regions of Macedonia. Once treatment received under the Bulgarians became common knowledge, emotions flared and the warfare became merciless. ${ }^{189}$

Bulgaria was encircled by Serbia, Greece and Romania. Bulgaria had alienated Russia by not being more flexible in territory division with its former allies. On 13 July, Ottoman forces under Enver began to advance beyond the Enos-Midia line established by the Treaty of London. ${ }^{190}$ Sir Edward Grey, English Secretary of State for Foreign Affairs,

${ }^{188}$ For a complete review of Bulgarian intrigues, see George E. Mylonalas, The Balkan Wars (St. Louis: Eden Publishing House, 1946), 88-96.

${ }^{180}$ Cassavetti, 336-340; and Justin McCarthy, Death and Exile: The Ethnic Cleansing of Ottoman Muslims, 1821-1922 (Princeton: The Darwin Press, Inc., 1995), 135-164.

${ }^{100}$ F.O. 32784/32304/13/44, No. 111, Grandville to Grey, Berlin, 16 July 1913. In Gooch, Vol. IX, Part II, 914. 
warned the Ottomans that the risk of war was serious if movement beyond the Treaty of London border continued. The Grand Vizier, Mahmoud Shefket, informed the English, that the "chauvinistic elements of Committee have decided on forward policy." 191 The goal of the Ottomans was Adrianople. Lord Granville, charge d'affaires at the British Embassy in Berlin, voiced London's view that a Russian suggested naval demonstration would be "inefficacious and dangerous in view of possible eventualities." 192 The English would not commit troops and would not provide ships in order to inject Russian troops, thus making a naval demonstration little more than an expensive regatta. The Germans refused to participate in any coercion of the Ottomans. ${ }^{193}$ Enver recovered Adrianople on 22 July, and Ottoman forces also entered Kirk Kilisse on the same day. By 26 July London had accepted the reality that Thrace was going back to Ottoman control. ${ }^{194}$ On 30 July 1913 a peace conference met at Bucharest and arranged a five-day truce. This led to the Treaty of Bucharest on 10 August 1913. ${ }^{195}$ Bulgaria's former Balkan allies, along with Romania, agreed to pull back to assigned borders and demobilize. However, the Ottomans were not party to this agreement. Ottoman security

19.F.O. 33024/32304/13/44, No. 344, Marlin to Grey, Istanbul, 17 July 1913. In Gooch, Vol. IX, Part II, 924.

${ }^{192}$ F.O. 33829/32304/13/44, No. 117, Grandville to Grey, Berlin, 22 July 1913. In Gooch, Vol. IX, Part II, 929.

${ }^{193}$ F.O. 33990/32304/13/44, No. 273, Buchanan to Grey, St. Petersburg, 23 July 1913. In Gooch, Vol. IX, Part II, 931.

${ }^{194}$ F.O. 34385/32304/13/44, No. 352, Grey to Marlin, London, 26 July 1913. In Gooch, Vol. IX, Part II, 939.

${ }^{195}$ A copy of the treat can be found in Gooch, Vol. IX, Part II, 1068-1070. 
concerns, which necessitated the retaking of Adrianople, were not addressed in the Treaty of Bucharest. The Bulgarian massacre of Muslims in and around the Maritz River region tempted the Ottomans to declare war officially but the English warned such official sanction of the war already in progress might invite Great Power (Russian) intervention. No war was "officially" declared. 196

Disregarding warnings from London, Enver pushed beyond Maritz and to Mustapha Pasha by 18 August 1913. This move brought additional warnings of intervention by the Great Powers but forced King Ferdinand to accept the inevitable in regard to Thrace. Bulgaria accepted a peace treaty with the Ottomans on 17 September 1913 with the new frontier starting at the mouth of the Maritsa River and ending north of Midia on the Black Sea. The peace treaty gave the Ottomans twice the territory awarded under the Treaty of London and had the peculiarity of being a peace treaty between two countries who were not officially at war. The Ottomans regained lost territory as a result of her own military effort and in defiance of the decisions of the British. "The Independent Government of Western Thrace," the governing organ of territory ceded by Bulgaria, was required to demobilize by the peace treaty but with the continual reports of Bulgarian massacres of Muslims, such action did not materialize. .

The loser in the Third Balkan War on the ground was Bulgaria who lost much of Macedonia and Thrace. But the real loser was Russia. Russian influence failed to prevent a falling out between victors in the First and Second Balkan wars. The attempt to

${ }^{196}$ F.O. 37649/32304/13/44, No. 302, Buchanan to Grey, St. Petersburg, 14 August 1913. In Gooch, Vol. IX, Part II, 982. 
mediate a workable armistice through St. Petersburg never materialized and Russian schemes to intimidate Istanbul failed when no other Great Power would support such action. In the end Czar Nicholas was not committed to fight over that Balkan issue, and the Ottomans recognized it.

Enver won back much of Thrace, and political rewards followed. The Ottomans now found themselves back in charge in Thrace and assured of financial backing from the Great Powers. The success of the C.U.P. increased the group's prestige in the country, but it also led to chauvinism and xenophobia.

The naval lessons of the Balkan Wars were not lost on the Ottomans. The Ottoman fleet performed well, but it lacked the resources to fight in both the Black and Aegean seas at the same time. The need to fight a two-sea conflict necessitated fleet expansion that led to an Ottoman naval buildup. Funding for Ottoman fleet operations for 1912 increased to $\$ 7,733,250$, up from an estimated $\$ 3,000,000$ in $1909 .{ }^{197}$ The modest increase of the Ottoman naval budget is dwarfed by other regional powers. Table 16 lists the budgets and changes from 1912-1914.

The lessons gleamed form the war such as use of airplanes, need for seagoing destroyers, some amphibious capabilities, and targeting of naval gunfire, influenced all three naval commands to rethink expansion plans. The naval race by Greece began is earnest once the war was concluded. But first Greece publicly paid tribute to the British naval mission in general and Admiral Tufnell specifically for the remarkable progress of

${ }^{197}$ Ahmed Emin, Turkey in the World War (New Haven, CT: Yale University Press, 1930), 94. 
TABLE 16

REGIONAL NAVAL BUDGETS AND CHANGES, 1912-1914

$1912-1913$

Italy

France

England

Russia

Austro-Hungarian
$1913-1914$

$\$ 49,909,575$

$90,526,029$

$234,899,322$

$118,960,586$

$29,090,574$
$\%$ Change

$+16 \%$

$+10 \%$

$+5 \%$

$+28 \%$

$+3 \%$

Source: Viscount Hythe, ed., The Naval Annal 1913 (Portsmouth, UK: J. Griffin and Co., 1913; reprint, New York: Arco Publishing Co., 1970), 482, 476, 458-459, 484, 474.

the Greek fleet. ${ }^{198}$ The Russian Duma reacted to the war by increasing funds for the Black Sea Fleet. The Porte could not compete with Russia in ship construction. Ottoman yards were not sufficient for dreadnought building, and the Izmet Arrangement, which gave British shipbuilder Armstrongs the authority to erect a navy yard at Golcuk, along with management control of the Tersane-i Amire, had not been in effect long enough to show potential. ${ }^{199}$ Had this agreement matured in 1900 , the Ottoman fleet could have been better equipped to counter threats to the Empire. The Ottoman fleet could not expand sufficiently using indigenous resources and had to compete with other non-producers of dreadnoughts in the open market. This led to diplomatic intrigue, inflated prices, and a naval race to World War $I$.

${ }^{198}$ Halpern, The Mediterranean Naval Situation, 328.

${ }^{199}$ Güleryüz, 17-18. 


\section{CHAPTER IV \\ OTTOMAN BATTLESHIP ACQUISITION}

The account of the battleship acquisition by the Ottoman government from 19001916 has been viewed as a result of the naval race gripping the industrial world prior to World War I. But unlike industrial powers, the Ottoman Empire attempted to maintain territory coveted by Western Europeans and not subject a foreign populace. Prior to the Balkan wars, Istanbul pursued ship purchases more in common with coast guard and revenue duties than power projection. This policy served Istanbul well. However, with the injection of one battleship, the naval purchases of three countries--Greece, Russia and the Ottoman Empire--changed.

The arms race in the Aegean region began in earnest when the Greek millionaire, Georgios Averoff, bequeathed $£ 280,000$ towards an armored cruiser from the Italian shipbuilder Orlando in October 1909. Orlando had begun to build the Pisa class cruiser under speculation, since no buyer had been contracted prior to commencement of construction. Construction of warships via speculation allowed for constant employment at shipyards and favorable rates for steel, ordnance, and engineer. Speculation also allowed for a ship to be sold to the highest bidder, leased to friendly foreign governments, or, if no successful customers comes forth, marketed to the home government at favorable prices. During this period, in addition to the cruiser, the Royal Greek Navy acquired four destroyers built originally for Argentina, along with two German models. 
Also, two submarines and six torpedo boats were ordered. Added to this, nine merchantmen were converted into auxiliary cruisers. Moreover, the three old Hydra class fcoast defense ships were rearmed with modern English quick-firing guns. Finally, in order to better utilize this force, a British Naval Mission was requested and in place by $1911 .^{200}$

In order to counter the Greek threat, the Ottoman Grand Vizier, Sadrazan Osman Pasha, discussed with Major von Stremple, German military attaché, the desire of the Ottoman navy to purchase an armored cruiser and a number of destroyers. The Ottomans complained that London refused to sell a modern ship, and Admiral Williams instead wanted the Porte to bid on the HMS Triumph and HMS Swiftsure. The two battleships were originally built for Chile and purchased by the Admiralty during the Russo-Japanese War to forestall acquisition by Russia, but London would only offer two old Royal Sovereigns class pre-dreadnoughts. ${ }^{201}$ Williams advocated a large flotilla of destroyers and torpedo boats in order to achieve the maximum coastal coverage for the funds available and small ships would allow for more responsibility to younger English-trained officers. Nevertheless, the Porte demanded battleships and considering the dominant view that naval power required such platforms, Williams' views were inconsequential.

${ }^{200}$ Robert Gardiner, ed., Conway's All the World's Fighting Ships 1906-1921 (London: Conway's Maritime Press, 1985; reprint, London: Conway Maritime Press, 1992), 328.

${ }^{20}$ Halpern, The Mediterranean Naval Situation, 316. 
The concern of the Ottoman government in countering the naval threat imposed by the Greek cruiser can be derived by the haste placed upon this purchase. The Porte acted as if the time for normal negotiations did not exist and since a large modern cruiser was needed now and none existed in England, Istanbul looked to Germany. The request for the four destroyers was quickly agreed upon. On 30 January 1910 the German Admiral Alfred von Tirpitz agreed to sell S165-S168. The Schichau A.G.-built vessels would become the Mauventi-i Milliye-class. The ships would prove to be excellent craft, inexpensive, durable, and a good match for repair facilities in the Ottoman Empire. Istanbul's use of German torpedoes ensured future German armament purchases and thus Germany would have influence in Ottoman naval affairs.

Acquiring the cruiser-type vessel would be more complicated. German Secretary of State Schoen informed the Porte that the newly completed SMS Blücher would be the ship transferred. German naval commanders quickly squelched the possibility of the Blücher being delivered to the Ottomans without full restitution. The reasoning behind full restitution lay in the Navy Law Admiral Tirpitz maneuvered through the German Parliament. This legislation fixed the number of ships and provided for their automatic replacement after 25 years of service. This "iron budget" prevented parliament from forestalling the timely replacement of ships by making the ships' replacement a matter of law. Any deviation from this program would necessitate full restitution or a change in 
the Navy Law. ${ }^{202}$ Compounding the situation, a ship such as the Blücher could receive proper shipyard work only in Germany, because the Ottoman yards lacked facilities capable of supporting such a ship. Before the Blücher could be transferred, the Porte would have to agree to full restitution along with all future ship orders through German yards. Ottoman finances prohibited such an agreement and behind the scenes, fear of another round of Ottoman extortion demands, as experienced in 1900, negated any thought of builder financing.

The German Foreign Ministry revised the discussions with the Ottoman government and offered the nearly completed Von Der Tann for $\$ 10,500,000$. However, the Ottomans still desired the Blücher. Germany's Kaiser decreed on 8 April 1910 that both the Von Der Tann and the Blücher could be purchased for $\$ 10,466,960$ each. ${ }^{203}$ This was an amount well out of the question for the Ottoman Empires. As discussions over ship purchases continued, the Greek cruiser $A$ veroff was completing its fitting out phase at Italy's Livorno shipyard. The Porte contacted Krupp and Blohn \& Voss to inquire about the unfinished Mollke, still fitting out at Hamburg. The Moltke did not have the aft two turrets installed. However, with a main armament of six $280 \mathrm{~mm}$ guns to the Averoff's four $240 \mathrm{~mm}$, and a sea speed of 25 knots to the Greek ship's 22 knots, the Moltke was more than a match. If an agreement was reached, the aft two turrets would be

${ }^{202}$ Gary Weir, Building the Kaiser's Navy: The Imperial Naval Office and German Industry in the von Tirpitz Era, 1890-1919 (Annapolis: Naval Institute Press, 1992), 8091.

${ }^{203}$ Guleryüz. 16. 
fitted in Istanbul after delivery.

All the discussions over which battle cruiser would be sold to the Ottomans came to a halt on 15 July 1910. Tirpitz stopped all negotiations over new ship transfers and offered four pre-dreadnought battleships of the Brandenburg-class for sale at ten million marks, or $\$ 2,378,854$ each. The Ottomans selected the SMS Kurfurst Friedrich Wilhelm and the SMS Weissenburg and the sales contract was signed on 5 August 1910. Both ships were in active fleet status. The Ottoman crews boarded the ships at Wilhelmshaven and began takeover while in transit to the Ottoman naval base at Canakkale. Official transfer was completed by 1 September 1910 and the two ships were renamed Barbaros Hayreddin (the former Kurfurst Friedrich Wilhelm) and Torgud Reis (the former Weissenburg). ${ }^{204}$

In order to counter the Ottoman battleship purchase, the Greeks attempted to buy two old French battleships, the Brennus and Bouvet. However, the French Minister of Marine, Admiral Lapeyère, refused to sanction the sale, citing fear of diminishing the fleet by two old but still capable warships. ${ }^{205}$

The naming of the Brandenburg battleship Barbaros Hayreddin is an excellent indication of the direction the Porte intended to take the Ottoman navy. Barbaros Hayreddin had been an Ottoman admiral who had been master of the Mediterranean in

${ }^{204}$ Fred T. Jane, ed., Jane's All the World's Fighting Ships, 1911 (London: Sampson Low Marston, 1911); reprint, New York: Arco Publishing Company, 1969), 452.

${ }^{205}$ Lapeyère to Minister of Foreign Affairs, Paris, 8 December 1910, cite in Halpern, The Mediterranean Naval Situation, 324. 
the seventeenth century, at the height of the Ottoman Empire. ${ }^{206}$ Payment for the two battleships and the four destroyers amounted to $\$ 5,947,136$, or 25 million marks. The funds for the ships came from the Ottoman Naval Society. German General von Stemple had suggested to the Porte that a foundation similar to the German Flottenverein, or Naval Society, could be helpful in fostering national unity and pride. The German Naval Society was by far the largest in Europe and had been very successful in gathering support from the middle class. ${ }^{207}$ The Donanna-i Milliye Cemiyetti (National Help Fund for the Fleet) was founded in Istanbul on 19 July 1910. The main objective of this fund was to restore the naval balance in the Aegean..$^{208}$

The Naval Society contracted for the ships and then proceeded to raise funds by public subscription. In addition, the Deutsche Bank held $\$ 3,092,511$ on account for the deposed Abdul Hamid and these funds were not discovered until after he had been deposed. ${ }^{209}$ The Naval Society used this account at the Deutsche Bank and funds garnered from public subscription to pay off the ships by August 1911.

Opposition parties in Istanbul protested that the price paid for the two battleships was too high because the ships had been built in 1891 and were pre-dreadnoughts. They

${ }^{206}$ Emle Bradford, The Sulian's Admiral: The Life of Barbarossa (New York: Harcourt, Brace \& World, 1968), 193-200.

${ }^{207}$ Wilhelm Deist, Flottenpolitik und Flottenpropaganda: Das Nachrichten Bureau des Reichsmarineamtes, 1897-1914 (Stuttgart: Deutsche Verlagsantalt, 1976), 157; cited in Paul G. Halpern, A Naval History of World War One (Annapolis: Naval Institute Press, 1994), 3.

${ }^{208}$ Guleryüz, 14.

${ }^{200}$ Paneth, 66. 
had been modernized in 1902-1904 and had come straight from the active Germany fleet. But The New York Times described the ships as "rattletraps," unusable in hot climates and little more than "old crocks."210 The purchase of the former German battleships also created a political uproar within the government between nationalists and Anglophiles. Hoping to quiet the uproar and keeping with the policy that armament purchases be spread around, the Ottoman government approached London concerning the Brazilian ships Minas Gerais and Rio de Janeiro. The discussions went nowhere due to financing difficulties. German banks, the Dresdner and the Deutsche, refused to finance non-German ship construction or purchases. However, Vickers shipyard at Burrows-in-Furness, England, agreed to carry some debt. As a result, the battleship Resadiye was ordered on 6 August 1911. Not to be left out of Ottoman naval purchase, from Armstrongs came the battleship Mehmet Resad $V .^{211}$ All construction was halted during the Balkan and Italian wars. The Mehmet Resad $V$ and the Resadiye had a length of 567 feet, beam of 93 feet, main armament of $10 \times 13.5^{\prime \prime}$, secondary armament of $16 \times 6^{\prime \prime}$, a gross tonnage of 23,000 , and a speed of 21 knots. Following the outbreak of the Balkan War, Armstrong demanded better guarantees of payment, and work was suspended. Subsequently, the contract was canceled on the Mehmet Resad $V$.

Athens responded to the Ottoman contracts by placing orders with Germany's Vulcan shipyard for a battle cruiser to be named Salamis. The Greek complaint of British

${ }^{210}$ The New York Times, 14 August 1910.

211Gardiner, 391. 
shipyard prices and delays in delivery, coupled with favorable German financing, caused great concern in London. In spite of a British Naval Mission and a French Army Mission, the Germans walked away with the naval contract.

The growth of German influence in Istanbul disturbed the British naval mission and made the task of securing naval contracts difficult. In order to increase British influence Admiral Limpus suggested that London do two things: sell Istanbul two predreadnoughts after the Balkan wars; and agree to train thirty Ottoman naval officers in England. First Sea Lord Battenberg opposed the sale of any pre-dreadnought and questioned the value of the Ottoman naval mission. Churchill took the opposite position and supported the sale in order to use the proceeds to buy planes. The British Admiralty Board decided to support Limpus and offered Istanbul two Royal Sovereign-class predreadnoughts but with the removal of Shefket Pasha as Grand Vizier in June 1913 all talks ceased. ${ }^{212}$

During the initial phase of the Balkan wars, the Porte made approaches to Argentina concerning the possible sale of the Moreno and the Rivadavia, which were being fitted out in the United States. The Moreno, built by the New York Shipbuilding Company in Camden, New Jersey, and the Rivadavia, by the Fore River Company in Quincy, Massachusetts, were not "officially" for sale. But the Ottoman ambassador in London, Tewfik Pasha, requested British advice on the condition of the ships. The British Admiralty declined to express an opinion on ships building in foreign yards. The ${ }^{212}$ Marder, 303. 
French ambassador in Istanbul, Maurice Bompard, also reported that the Porte would purchase one of the Argentine battleships and that Buckman Pasha, an American engineer created admiral by the former Sultan, Abdul Hamid, was supposed to be involved in the transaction. The French also reported that the purchased ship would be crewed by mercenaries and would soon sail for the Dardanelles. ${ }^{213}$ The report of the pending sale and crewing by mercenaries was also relayed by the French Admiral Dartige du Fournet, commander of the French naval forces in the Levant. Fournet reported that the Americans had supposedly offered to sell a battleship and some destroyers, fully armed and crewed, out to Istanbul, fighting the Greek fleet and bombarding the Greek fleet at Piraeus on the way. Fournet also reported that the Porte approached Berlin on the availability of the SMS Goeben. ${ }^{214}$ The Porte was not successful in acquiring warships to confront the Balkan allies' aggression. But the Porte's action indicated a strong desire to obtain such platforms in the belief that doing so would provide a level of security surely needed. Security other nations found questionable.

The South American republics had been experiencing a naval race since 1908 and in Brazil a political coup was the result. The Brazilian battleship Minas Gerais experienced a mutiny in 1910. This action motivated the Brazilian government to reconsider having the Rio de Janeiro and the Minas Gerais at the same time. The Brazilian battleship Sao-Paulo was not directly involved in the Minas Gerais mutiny, but

213 Bompard to Minister of Foreign Affairs, 7 December 1912, Mae, TurquiePolitique, cited in Halpern, The Mediterranean Naval Situation, 332.

${ }^{214}$ Halpern, The Mediterranean Naval Situation, 332. 
the specter of all three dreadnoughts actively engaged in rebellion convinced the Brazilian Minister of Marine to offer the Rio de Janeiro for auction. ${ }^{215}$

The fear of mutiny was not the only reason compelling Brazil to sell the Rio de Janeiro. British businessmen had smuggled out of Brazil wild rubber plants and had succeeded in transplanting the plants in Malaya. The fall in rubber exports caused by the Britishsponsored Malayan rubber plantations cut the export revenue for Brazil to a level making the battleship unattainable. ${ }^{216}$

The Porte, reacting to reports that Greece was inquiring into purchasing the Rio de Janeiro, began to search out Armstrongs officials in order to consummate the sale to Istanbul. Admiral Limpus had asked the British ambassador in Istanbul to inquire about London's buying the ship to avoid Athens acquiring the vessel. London did not foresee a need for the ship, nevertheless, the Admiralty informed the French naval attaché that the Italians were interested in the ship. Paris was concerned that Italian ownership of the Rio de Janeiro would upset the Mediterranean balance of power into Rome's favor.

French Prime Minister Pichon did not want the ship because of the financial burden French naval orders had placed on the budget. But Pichon was open to renegotiating a Greek loan in order to allow Athens to purchase the ship. The French needed time in order to formulate the agreement with the Greeks, but London needed to

${ }^{215}$ Richard Hough, History of the Modern Battleship: Dreadnought (New York: Macmillan Company, 1964), 74.

216Richard Hough, The Great Dreadnought: The Story of the H.M.S. Agincourt, the Mightiest Battleship of World War I (New York: Harper and Row Publishers, 1966), 62. 
know the status of the Greek talks because past discussions between Athens and Armstrongs seemed to be aimed solely at preventing the purchase of the ship by Istanbul. The First Lord of the Sea, Winston Churchill, informed Paris that it was most important that Greece and not Italy acquire the ship. Italy was still a member of the Triple Alliance and thus a potential threat. Greece wanted the ship, but the negotiations required time, and Pichon once again requested the British Admiralty delay Armstrongs's selling the vessel. ${ }^{217}$ In the end, Italy did not aggressively pursue the purchase, and the entire notion that Italy wanted the ship may have been the result of a bitter rivalry between the Italian shipbuilding yard Ansaldo against the group including Orlando, Vickers-Terni, Armstrongs, and the Banca Commerciale..$^{218}$

The Greek government continued negotiating with Paris in order to consummate a loan sufficient to cover the Rio de Janeiro and ship orders already placed in French yards. Paris suspected Athens of using French concerns over the vessel in order to obtain better conditions for the loan. The French chargé d'affaires in London also suspected Armstrongs and Vickers of conniving in order to escalate the price of the vessel and ultimately of receiving the concession of reorganizing the Ottoman dockyards. The preceding fall, Sir Vincent Caillard, formerly an English representative on the Ottoman Debt Commission and currently a director of Vickers, and Rear-Admiral Ottley, a retired naval officer who was a director of Armstrong, had been successful in reaching an naval

217Pichon to Cambon, Paris, 22 November 1913, cited in Halpern, The Mediterranean Naval Situation, 340. ${ }^{218}$ See note in Halpern, The Mediterranean Naval Situation, 340. 
agreement with the Porte. British firms would modernize the Ottoman shipyard at Istanbul and construct an arsenal with a floating dock in the Gulf of Ismid. ${ }^{219}$

Istanbul received the loan for the battleship through the French banker Périer, with Armstrongs guaranteeing the loan. The transfer of funds took place 29 December 1913 despite last-minute appeals from Greek Prime Minister Venizelou. ${ }^{220}$ The French bank, Périer, also received the concession for providing electricity to Jerusalem and constructing an electric street car line from Jerusalem to Bethlehem. ${ }^{221}$ With the loan secured, the Porte proceeded in submitting a bid for the ship.

With several bids submitted for the ship, Armstrongs decided to auction the ship outright. The participants of the auction are unknown, but reviewing the economic and political realities at the time of the auction rules out countries that could have constructed such ships for their own use or foreign sales. Using the premises that dreadnought construction benefits a nation's infrastructure eliminates all the major European powers and Japan. This leaves only nations which wanted and could afford a dreadnought but could not construct one, Greece and the Ottoman Empire fit this category. The auction date was 9 January 1914, and the final price was $\$ 13,625,000 .^{222}$ Renamed Sultan Osman-i Evvel, the ship was the largest battleship afloat. With a length of 671 , beam of

${ }^{210}$ F.O. 371/1846/50485, Mallet to Grey, 6 November 1913, Istanbul, found in G.P. Gooch and Harold Temperley, British Documents on the Origins of the War, 1898 1914, Vol. X, Part 2 (London: His Majesty's Stationary Office, 1934), 362.

${ }^{220} \mathrm{Halpen}$, The Mediterranean Naval Situation, 341.

221 The New York Times, 28 January 1914.

${ }^{222}$ Ibid . 
89 , main armament of $14 \times 12^{\prime \prime}$, secondary armaments of $20 \times 6^{\prime \prime}$, gross tonnage of 27,500 , and a speed of 22 knots, the Sultan Osman-i Evvel would restore balance in the Aegean Sea region.

The Ottoman government fulfilled the agreement to acquire future ships from Armstrong. by placing orders for two scout cruisers, two submarines, and four destroyers. Further orders were placed to Francis Schneider \& Cie. in Nantes, France, for destroyers in 1914, with six more planned in 1917. Rounding out Ottoman naval purchases, Italy's Ansaldo \& Cie received orders for four destroyers of 700 tons each to be delivered in $1917 .{ }^{223}$ Ordering warships from an Italian firm so soon after the Tripolitania war suggest possible political payback to Rome for not biding on the battleship.

The efforts to pay for the ships out of a treasury still recovering from two recent wars were daunting. The Minister of the Interior, Talaat Bey, was tasked to provide $\$ 17,010,000$ from an agrarian society still reeling from wars, internal migration from Balkan atrocities, and political infighting. Talaat arranged an advance on the annual sheep tax from the Ottoman Bank in the sum of $\$ 1,215,000$, from a fund known as the public debt $\$ 486,000$, and the tobacco tax $\$ 243,000$. The civil service and municipal workers' December 1913 pay was expropriated, and a bread tax levied upon the general populace.

${ }^{223} J a n e$, Jane's All the World's Fighting Ships, 1914, 409-419. 
Talaat and the C.U.P. generated a battleship fundraising program bordering on a spiritual crusade. In large cities, collection boxes marked "for our fleet" gathered small change. Ferry boats on the Bosporus gathered collections from passengers, and women donated hair to be sold for the fleet. Former Grand Viziers Khazi Mukhtar Pasha and Kutchuk Said Pasha both became targets for large "contributions" from the C.U.P. The rich became targets of the C.U.P.'s pamphlet campaign demanding donations. Such action created a personal attachment to the ships. The standing of the Ottoman fleet had risen along with the donations, and the populace began to embrace the notion of a powerful fleet capable of projecting power ${ }^{224}$ In April 1914 the Porte was able to arrange a $\$ 155,520,000$ loan from France. This amount allowed for liquidating the floating Ottoman debt, settling back pay for civil servants, providing $\$ 1,944,000$ for a railway line and enough for the entire outstanding balance on the Sultan Osman-i Evvel. 225

In October 1913 the British naval attaché in Rome reported the possible sale by the Italian navy to Istanbul of the large armored cruiser of the Pisa class and the small cruiser Libia, the former Ottoman cruiser Drama. ${ }^{226}$ The Italians had shown concern over the deal to modernize Ottoman yards by Vickers and Armstrongs, especially the possibility a naval base could be erected in the Bay of Giova or Marmaritza. Italy

${ }^{224}$ Hough, The Great Dreadnought, 97-99

${ }^{225}$ Ibid., 100.

${ }^{226}$ F.O. 371, Captain Boyle to Dering, Rome, 18 October 1913, cited in Halpern, The Mediterranean Naval Situation, 338-339. 
considered both regions in Rome's sphere of influence, regardless of the treaty ending the Italo/Ottoman War, which reaffirmed no such sphere existed.

The purchase of the Rio de Janeiro by the Ottoman government preempted the sale of the ship to either Greece or Italy. Italy offered to exchange two Pisa class cruisers to the Ottomans for the contract. In order to entice the deal, Italy offered to sell two submarines for $\$ 13,219$ each to the Ottomans. ${ }^{227}$ Istanbul declined.

Rounding off Ottoman acquisition of dreadnoughts would be the Faith Sultan Mehmed. The ship was ordered on 29 April 1914 and was a carbon copy of the Vickers ordered Resadiye, with completion scheduled in twenty-two months. The Ottoman Naval Minister, Ahmad Djemal Pasha, hoped to have two fleet units: one consisting of three dreadnoughts, two light cruisers, twelve destroyers, and four submarines, and the other consisting of the old battleships and torpedo boats. ${ }^{228}$ In order to facilitate this program, Djemal ordered the Ottoman yard representatives Reuf Bey and Wassif Bey to refrain from demanding or allowing shipyard changes. Djemal suspected the English yards were intentionally delaying turning over the ships. ${ }^{229}$ In addition to the dreadnoughts ordered, Armstrongs, the provider of ordnance for all three ships, was to provide projectiles and propellant for both fleet units and the forts overlooking the Bosporus and Dardanelles Straits.

${ }^{227}$ Güleryüz, 17.

${ }^{228}$ Ahmad Djemal Pasha, Memories of a Turkish Statesman 1913-1919 (London: George H. Doran Co., 1922), 95.

${ }^{220} \mathrm{Ibid}$., $91-92$. 
Contemporary writers on naval fleets in the twentieth century have implied the names of the Vickers and Armstrong battleships were changed. Ahmet Güleryüz and Bernd Langensiepen, authors of The Ottoman Steam Navy 1828-1923, write that the Mehmet Resad $V$ was changed to Resadiye. This belief is also reported in Fred T. Jane's All The World's Fighting Ships, 1914. However, from "builder" identification expressed in Güleryüz's and Jane's works, along with Robert Gardiner's Conway's All The World's Fighting Ships 1906-1921, it can be shown that the Vickers battleship, Resadiye, was not canceled and was completed only to be seized by the Royal Navy in 1914. Construction on the Armstrong battleship Mehmet Resad V, ordered in June 1911, was halted and subsequently canceled in 1912. There is no evidence the canceled Armstrong battleship was ever named Resadiye, nor do records show a reference to either name. However, both names are a reference to the reigning Sultan, Mehmet Resad V. Sultan Mehmet Resad V's family name was Resadiye.

American involvement in the naval race between Greece and the Ottoman Empire centered around two relatively new but under-powered battleships. The USS Idaho (BB-24) and the USS Mississippi (BB-23) were both laid down in 1905 and launched in 1908. The ships were in general designed similarly to the Kansas-class, but displaced only 13,000 tons. This reduction was effected by reducing the speed to seventeen knots and the normal coal supply to 750 tons. Additionally, the number of seven-inch guns was reduced to eight versus twelve on the Kansas class and the freeboard aft was one deck lower than in the Kansas. The reduction in size, speed, and coal capacity of these vessels was contrary to the naval principle that "for the best efficiency, ships that are to operate 
together should possess the same tactical and strategically qualities." The ships were built because the shipbuilder, William Cramp \& Sons, Philadelphia, Pa., did not have a drydock long enough to construct a standard Kansas size battleship. Senator Hale of Pennsylvania used his influence on the Naval Affairs Committee, to insure Cramp received the contract. The construction of the two battleships was allowed over the objections of naval authorities as a consequence of a curtailment in the appropriations. ${ }^{230}$

The difficulties faced by American admirals was how to use battleships that were fairly new but too slow to steam with older ships. The ships also did not have adequate range because of smaller coal bunkers and the low freeboard and reduced weight greatly diminished the sea-keeping abilities of the two battleships. The combination of slow speed, reduced range, diminished sea-keeping abilities, and decreased secondary armament condemned the Idaho and Mississippi to ancillary roles of reserve ship and midshipmen cruises. ${ }^{231}$

The Greek government wanted warships to counter the Ottoman purchase of the Rio de Janeiro. The New York Shipbuilding Company's representative, Fred J Gauntlett, offered to arrange the acquisition of five old battleships from the United States navy and immediately to sell three to Greece on the understanding that Athens would place an

${ }^{230}$ William Hovgaard, Modern History of Warships (London: Unwin Brothers, 1920; reprint, London: New Impressions, 1970), 109; and see Josephus Daniels, The Wilson Era Years of Peace-1910-1919 (Chapel Hill: The University of North Carolina Press, 1944) 382-383.

${ }^{231}$ US Navy Department, Dictionary of American Naval Fighting Ships, Vol. IV (Washington: U.S. Government Printing Office, 1969), 388. 
order for a super-dreadnought. These ships in question would be the U.S.S. Kersage, U.S.S. Kentucky, U.S.S. Indiana, U.S.S. Massachusetts, and U.S.S. Oregon. All the ships were at the end of operational service, pre-dreadnought, and of little value to the American fleet. Greek Prime Minister Venizelos reviewed the offer and declined to buy. ${ }^{232}$ Venizelos still desired battleships and found favorable financing in France. By the spring of 1914, Athens had a dreadnought building, another on order from France, and a battle cruiser building in Germany. Greek naval power would be on par with the Ottomans by the summer of 1917. Additionally, four destroyers being fitted out in Germany were released to Greece by 16 January 1914.

In May 1914 President Wilson of the United States informed the Greek legation in Washington that the United States Navy might be prepared to sell the Idaho and Mississippi if the sale were sanctioned by Congress. Venizelos instructed the Greek Minister in Washington to accept the offer, sight unseen, and to speed the deal, Venizelos sent his Marine Minister, M. Vouros to negotiate a price with Adm. David Taylor, Chief of Construction, United States Navy Department. ${ }^{233}$ On 20 May 1914 United States Navy Secretary Josephus Daniels appeared before the Senate Committee on Naval Affairs advising acceptance of the Naval Appropriations Bill amendment providing for the sale of the two battleships. The amendment offered by Senator Lodge of Massachusetts, did not name the country or minimum acceptable price. The

${ }^{232}$ Hough, The Great Dreadnought, 76.

${ }^{233}$ Daniels, 383. 
amendment passed without alteration or debate. The House of Representatives on 16 June debated Senate Amendment 71 to the Naval Appropriation Bill. In the House, a small but powerful group of representatives, dubbed "the small navy" advocates, viewed the proposed sale as a means of circumventing regular navy appropriations at the expense of Greece. The fight over the proposal lasted into the night.

The fact that Greece openly desired to redeem the Aegean islands and the Anatolian mainland was no diplomatic secret. Greek navy purchases consisted of ships that could seize territory via the Aegean Sea: thus the need for a large navy capable of operating in the littoral regions of the Aegean. This course of action had proved prudent during the Balkan Wars of 1912-1913, when Greek warships seized the majority of Ottoman islands in the Aegean and Crete seas. Greek desires to complete the redemption of the Ottoman Greek community was so prevalent that the United States ambassador in Istanbul, Henry Morgenthau, insinuated such action would launch the next war. ${ }^{234}$

On 11 June 1914 the Ottoman Minister of Marine, Ahmad Djemal Pasha, confronted Ambassador Morgenthau over the rumored American sale of the two battleships. Djemal noted the friendly, evenhanded approach the United states had exhibited towards the Ottomans and expressed a willingness to see future relations with the United States remain good. The United States President, Woodrow Wilson, openly desired to stay neutral in any European hostilities, but selling the warships to Greece, with Athens boasting the desire to redeem Ottoman Greeks, made the sale of the ships an

${ }^{234}$ Henry Morgenthau, Ambassador Morgenthau's Story (New York: Doubleday, Page \& Company, 1918), 48. 
unneutral act. Morgenthau noted that the Ottomans had purchased the Sultan Osman-i Evvel from Brazil and that Greece had as valid a right to acquire warships from the United States. Djemal noted that if the sale of the battleships were strictly a commercial sale, the Ottoman government was willing to bid for the ships. Morgenthau advised Djemal that the Porte should contact the Ottoman ambassador in Washington and address President Wilson directly. ${ }^{235}$

The Porte found some relief in the "small navy" minority in Congress. Rustem Bey, the new Ottoman ambassador to Washington, presented his credentials to President Wilson on 22 June. At this meeting, the proposed battleship sale was mentioned.

President Wilson informed the ambassador that Athens had given assurances the warships were wanted for peaceful purposes. Ambassador Rustem issued an official statement as following:

The contention that the sale of the two battleships will restore the naval balance between Turkey and Greece and would prevent the explosion of hostilities is faulty. If the two American battleships came into possession of Greece before Turkey gets the two battleships now under construction for her, they will add to the considerable superiority she [Greece] already enjoys over Turkey. If she [Greece] gets them after Turkey gets hers, which are super-dreadnoughts, she [Greece] would fall into a state of distinct inferiority. The American action would miss its very honorable object and in reality would amount to taking sides with Greece against Turkey in the naval rivalry between the powers. ${ }^{236}$

The House debated the amendment again on 23 June. Presidential pressure encouraged House members to pass the bill as quickly as possible. The New York Times
${ }^{235}$ Daniels, 384-385..
${ }^{236}$ Quote cited in Hough, The Great Dreadnought, 81. 
quoted an unnamed navy official who said, "Greece would not have been willing to pay the price unless her needs were urgent." The Greek authorities had agreed to pay three times the real market value of the two pre-dreadnought battleships and the financial aspect had been used to support the President's cause. Opposition was voiced by Representative Stafford of Virginia, who stated, "Because Turkey may be a despised nation, it is no reason why our [U.S.] government should tinge its own policy by becoming a party to the difficulties existing between Turkey and Greece. . ."237 The Naval Appropriation Bill was passed by 175 votes to 89 with the final asking price for the ships $\$ 11,500,000 .^{238}$ The New York Times, citing ambassador Rustem's concerns, suggested Istanbul make an offer for the warships exceeding the asked price. ${ }^{239}$ On 22 June 1914, at 2:00, Commander P. D. Tsouklas of the Royal Greek Navy called upon the President and arranged the sale. As Commander Tsouklas left the office of the President, the Ottoman ambassador Rustem entered, fifteen minutes too late to make a counter offer. ${ }^{240}$ The Louisville Courier-Journal of 1 July 1914 reported upon the sale, "There will be no direct dealing between the United States and the Greek government involved in the sale of the battleships Idaho and Mississippi. Navy Secretary Joseph Daniels said the vessels were to be sold by the Navy Department to private firms, which would transfer

${ }^{23} \mathrm{~T}$ Ibin., 84 .

${ }^{238}$ For a complete review of the House debate on the sale of Mississippi and Idaho to Greece, see Congress, House, Naval Appropriation Bill of 1914, 2nd sess., Congressional Record, Vol. LI, Part XI, daily ed., 10571-10576, 10959-10973.

${ }^{239}$ The New York Times, 24 June 1914.

${ }^{240}$ Morgenthau, 53. 
title to the Greek Government." The Courier-Journal reported on 3 July 1914, just prior to the sale, that "the Greek government not in talks, the ships are to be sold to an agent of an American shipbuilding company."

The sale of the Idaho and Mississippi was formalized on 8 July 1914. The buyer was Fred J. Gauntlett, now a representative of the Newport News Shipbuilding Company, and the sale price was $\$ 12,535,276.98$. Congress voted to expend the proceeds from the sale on a third battleship of what was originally a two-ship order of New Mexico class. Subsequently two of the three battleships would be christened BB 41 Mississippi and $\mathrm{BB} 42$ Idaho. ${ }^{241}$

Both ships were relatively new, having been commissioned in 1908 . The armament and machinery were in excellent shape, and the vessels working in tandem could hold their own in a duel with whatever the Ottomans had or would have, including the Sultan Osman-i Evvel. Additionally, the Greeks possessed smaller ancillary ships in quantities sufficient to dominate battle space. During the Balkan conflict, Greek destroyers, with superior numbers, had dominated battle space while the Averoff had dueled with the Ottoman battleships. Even with the possible addition of the Sultan Osman-i Evvel, the Ottomans could face a Greek naval foe having two powerful squadrons separated sufficiently so that a diluted Ottoman force risked defeat.

The Mississippi was decommissioned on 21 July 1914 and turned over to the Royal Hellenic Navy the same day. Renamed Lemnos, the ship would stay in Norfolk,

${ }^{24}$ Gardiner, 117. 
Virginia for several weeks in order to facilitate turnover. The Lemnos had a length of $382^{\prime}$, beam of $77^{\prime}$, main armament of $4 \times 12^{\prime \prime}$, secondary armament of $8 \times 8^{\prime \prime}$ and $8 \times 7^{\prime \prime}$, gross tonnage of 13,000, and a speed of seventeen knots. ${ }^{242}$ The Lemnos (the ex-Mississippi) and the Kilkis (the ex-Idaho), by virtue of being acquired while still in American active service, were battle-ready. Both ships were fully armed and coaled. The Ottomans now faced the threat that the Greeks might strike first before the Sultan Osman-i Evvel could be conveyed into the Aegean theater. The Lemnos sailed for Greece the last week in July and arrived for transit through the Mediterranean the second week in August 1914. The Kilkis was turned over to the Royal Hellenic Navy at Villefranche, France. Djemal feared the Greek battleships could converged and, along with Greek submarines, overwhelm the Sultan Osman-i Evvel. ${ }^{243}$

Admiral Kerr, head of the British Naval Mission in Greece, was highly critical of the transaction and characterized Greek Prime Minister Venizelos as "penny-wise and pound foolish." Kerr described the two battleships as worn out and obsolescent, totally unfit for military service. The British Admiral preferred small ships for the Greek fleet but, just as importantly, English-built ships. German and French shipyards had received the bulk of Greek orders, and the British shipyards were concerned. The British Greek mission, just like the Ottoman mission, had the primary directive of securing contracts for British shipyards.

${ }^{242}$ U.S. Navy Department, Dictionary of American Naval Fighting Ships, Vol. III (Washington: U.S. Government Printing Office, 1968), 416.

${ }^{243}$ Djemal, 96; Morgenthau, 53. 
The fear of Greek attack upon the Sultan Osman-i Evvel was not a view the Ottomans held solely. In May 1914 the British Commander-in-Chief of the Mediterranean fleet, Admiral Michael de Robeck, warned Istanbul that Athens would attack the Sultan Osman-i Evvel with submarines as the ship transited the Straits of Gibraltar. Additionally, King Constantine of Greece alluded to a "preventive" strike prior to the ship's arrival in talks with German and British ambassadors. ${ }^{244}$ On 13 June 1914 the Ottomans declared a state of emergency in the Gulf of Izmit and the Dardanelles because of Greek naval maneuvers reinforcing the need to acquire the Sultan Osman-i Evvel to prevent a possible Greek preemptive strike.

In July 1914 Armstrongs delayed releasing the ship and Djemal appealed to the French to intervene with London to release the battleship. ${ }^{245}$ The warnings given to Djemal by Robeck and the endless delays from Armstrongs added to the perception that London did not want to release the ship. Djemal wrote that he believed the warning was an attempt to frighten the Ottomans into leaving the Sultan Osman-i Evvel in English custody until Resadiye was ready in late 1914.246

Djemal consulted with the British advisor to the Ottoman Navy, Admiral Limpus, and with written confirmation from the Armstrongs for a delivery date, decided to send the prospective crew of the Sultan Osman-i Evvel to England. The crew embarked on the

${ }^{244}$ Djemal, 96; and see Elliot to Grey, Athens, 28 May 1914, found in G.P. Gooch and Harold Temperley, British Documents on the Origins of the War, 1898-1914, Vol. X, Part 1 (London: His Majesty's Stationary Office, 1935), 253.

${ }^{245}$ Güleryüz, 29.

${ }^{246}$ Djemal, 96. 
Reschid Pasha with Captain Raduf Bey, the prospective commanding officer of the battleship. ${ }^{247}$ Captain Raouf earned the position of prospective commanding officer of the Sultan Osman-i Evvel by the exploits of the cruiser Hamidiye in the Balkan Wars. The Hamidiye was well crewed, disciplined, and professional, all due to Raoufs leadership. Preceding Raouf would be the engineers, Captain Hassan, Lieutenant Arrif, Lieutenant Mazmi, and others. Hassan was tasked with ensuring the Sultan Osman-i Evvel met Istanbul's requirements. Among the physical alterations required were the complete separation of engineering from line officers, both dining and sleeping quarters.

Plumbing fixtures were required to be lowered in order that feet, hands, and face could be washed in the oriental, or crouched, position. Water closets were removed in favor of cones sunk into the deck for squatting, with water taps placed for the left hand. The cultural specifications did delay the warship but shipyard conduct suggest intentional delaying tactics. ${ }^{248}$

The builder of the Sultan Osman-i Evvel, Armstrongs, had all the ordnance except the last turret installed, even though two guns had been finished for some time. Additionally, the gunsights had been completed but not installed. Finally, brass instruction plates or "tallies," used to provide direction, instruction, or information for communication, electrical, hydraulic, and ordnance equipment, were etched in Turkish with an English translation on the reverse. While the ship was the Rio de Janeiro, the

${ }^{247}$ Ibid., 91.

${ }^{248}$ Hough, The Great Dreadnought, 94. 
Portuguese tallies had no such English etching on the reverse. ${ }^{249}$ The Sultan Osman-i Evvel commenced sea trials on 7 July with turnover scheduled for early August. Further sea trials provided proof of the speed. On 17 July, on a measured nautical mile, the ship achieved $22.42 \mathrm{kts}$, well above the designed speed. But for unexplained reasons the ship did not return directly to the shipyard at Tyneside, but instead steamed north to Leith Harbour in Scotland for three days of idleness. While the ship was at sea, Europe found itself on the eve of World War I. The ship returned to Tyneside on 22 July.

In early June, the British Admiralty quietly suggested to Armstrongs and Vickers to decelerate judiciously the final stages of construction of the two Ottoman battleships. Though the Reshadieh was six months away from completion, the Sultan Osman-i Evvel needed only the fitting of gunsights, ammunition, and the final two guns to be completed. Captain Raouf had arrived on 22 July, and the crew on 27 July aboard the Neshid Pasha. Raouf voiced displeasure over the delays with Armstrongs officials and received assurances of delivery on 2 August.

On 31 July Germany sent an ultimatum to France and Russia concerning mobilization of troops and border violations inflicted upon German soil. Churchill decided to seize the Ottoman ships without consulting England's Prime Minister Lloyd George or the Cabinet. Instead he made his decision after talking with military leaders .${ }^{250}$ On 31 July Churchill ordered Armstrongs to hold the Sultan Osman-i Evvel: "Messrs.

${ }^{249} \mathrm{Ibid}$, 95-96.

${ }^{250}$ E. David Cronon, ed., The Cabinet Diaries of Josephus Daniels 1913-1921 (Lincoln: University of Nebraska Press, 1963), 153. 
Armstrongs should be informed that they [Armstrongs] must understand that in view of present circumstances, the Government cannot permit the ship to be handed over to a Foreign Power or to be commissioned as a public ship of a Foreign Government, or to leave their jurisdiction." ${ }^{125}$ On 31 July the Ottoman government paid the last installment of $\$ 3,402,000$ on the Sultan Osman-i Evvel. ${ }^{252}$ The prospective crew and captain had arrived at pier side to "officially" accept the ship, but English First Lord of the Admiralty, Sir Winston Churchill, ordered the ships requisitioned on 2 August. The Grand Vizier, Said Halim, along with the Interior Minister, Talaat Bey, confronted the British chargé d'affaires at Istanbul on how unfriendly an act seizing the warships had been. Addition, Talaat Bey reminded Beaumont that Churchill had waited until the last installment had been paid on the loan: a loan from English shipbuilders at twenty percent interest. ${ }^{253}$ Resentment over the requisition of the two ships is evident in the Sultan's declaration of war: "...England complains that Turkey without any preliminary notice bought two warships from Germany [Goeben and Breslau]. It should be borne in mind, however, that before war was declared, the English government ordered the seizure of two dreadnoughts that were being built for Turkey in British yards and that one of these dreadnoughts, the Sultan Osman, was seized half an hour before the appointed time when

${ }^{2 s}$ Hough, The Great Dreadnought, 121.

252E. D.W. Lumby, ed., Policy and Operations in the Mediterranean 1912-1914 (London: William Clowes and Sons, 1970), 427.

${ }^{253} \mathrm{Mr}$. Beaumont to Sir E. Grey, 3 August 1914, Istanbul. Found in J. D. Scott, Diplomatic Documents Relating to the Outbreak of the European War, Vol. II (New York: Oxford University Press, 1916), 1057. 
the Turkish flag was to have been raised over the ship; and that finally no indemnity was paid for these confiscations..." ${ }^{254}$ Resentment over the loss of the Sultan Osman-i Evvel and the Resadiye did not immediately lead to war with England or the feared attack from Greece. But the British action did remove any objections Anglophile in Istanbul had to the Ottoman-German alliance.

The political intrigue surrounding the Goeben and SMS Breslau began in midJuly 1914 and not upon the arrival in Istanbul of the two warships on 8 August. On 22 July the German ambassador to the Ottoman court, Baron von Wangenheim, recommended to the Ottoman Grand Vizier, Said Halim, and the War Minister, Enver Pasha, that Istanbul should not conclude an alliance of any kind. The Ottoman Empire faced the difficult task of implementing internal reforms and needed peace to be successful. Wangenheim urged Said Halim to explore support from one of the Great Power groups and not a military alliance. Istanbul was not prepared to conduct military operations and would have been a drain and not an asset. ${ }^{255}$ The belief that the Ottoman Empire would be a drain and not an asset was also voiced by the Austrian ambassador, Margrave Pallavicini, on 23 July. However, Kaiser Wilhelm II of Germany disagreed, stating, "Under no circumstances at all can we afford to turn them [the Ottoman Empire]

${ }^{254}$ Mears, 608.

${ }^{255}$ Wangenheim to Jagow, No. 362, 22 July 1914, Istanbul. Found in Max Montgelas and Walther Schücking, eds., Outbreak of the World War, German Documents Collected by Karl Kautsky (New York: Oxford University Press, 1924), 156-157. 
away."256 The Kaiser's views prevailed, and a Treaty of Alliance was agreed upon on 2 August 1914. The treaty provided for the protection of the Ottoman Empire from Russian aggression and gave the German military mission full control over the Ottoman ground forces. ${ }^{257}$

On 1 August 1914 Ambassador Pallavicini informed Said Halim that intelligence reports implied that Russia planned to attack the Bosporus, conduct an amphibious landing against Bulgaria, and sever communications with Austria by cutting the cables through Romania. Wangenheim suggested the Goeben be dispatched to Istanbul to reinforce the Ottoman fleet and check potential Russian aggression. ${ }^{258}$

The fighting commenced when Russia declared war on 2 August 1914. The German General Liman von Sanders, head of the military mission at Istanbul, along with Ottoman War Minister Enver Pasha, wanted permission from the German Foreign Office to seize three Russian merchant ships at anchor in Istanbul. The Grand Vizier refused to consent for fear the British would seize the two dreadnoughts building in British yards. ${ }^{259}$ Said Halim was hesitant to allow German or Austrian-Hungarian warships permission to transit the Straits, fearing it could antagonize Russia and complicate treaty negotiations

${ }^{256}$ Montgelas, 178. See also Ulrich Trumpener, Germany and the Ottoman Empire 1914-1916 (Princeton: Princeton University Press, 1968), 15.

${ }^{257} \mathrm{~A}$ copy of the treaty is found in a telegram from Wangenheim to Jagow, No. 409, 2 August 1914, Istanbul. Found in Montgelas, 529.

${ }^{258}$ Wangenheim to Jagow, No. 396, 1 August 1914, Istanbul. In Montgelas, 488.

${ }^{259}$ Wangenheim to Jagow, No. 416,3 August 1914, Istanbul. In Montgelas, 562563. 
with Bulgaria. ${ }^{200}$ Said Halim did have real concerns. Russia mobilized military units in western Russia on 31 August, along with naval units in the Black Sea. The Black Sea was neutral, and neither Germany nor Austria-Hungary had naval forces in the Littoral. The Ottomans faced Russian naval mobilization against a neutral Ottoman Empire; a buildup of Russian ground forces in the Caucasus; seizure of the Sultan Osman-i Evvel and the Resadiye by England; and a shortage of armaments for the defenses of the Straits. All this, coupled with the warning of an impending Russian invasion, placed Istanbul in a precarious position: how to keep neutral until the slow mobilization had progressed enough to be successful and how to protect the Empire from real threats.

Said Halim also faced the threat that Greece would attack immediately. The seizure of the two Ottoman battleships and the arrival in mid-July of the two American purchased warships gave Athens a considerable advantage in naval strength. Greek Prime Minister Venizelos still coveted Asia Minor and "Greater Hellas." Only at the expense of Istanbul could Greek aspirations be achieved. In mid-August, Venizelos favored an immediate attack on Thrace and a rush towards Istanbul. The Entente reacted unfavorably to this suggestion because of Russian desires for physical control of the Straits. Additionally, Greece's King Constantine, Kaiser Wilhelm's brother-in-law, desired neutrality. ${ }^{261}$

${ }^{260}$ Wangenheim to Jagow, No. 426, 4 August 1914, Istanbul. In Montgelas, 588.

${ }^{201}$ George H. Cassar, The French and the Dardanelles: A Study of Failure in the Conduct of the War (London: George Allen \& Unwin Ltd., 1971), 32-33. 
Ambassador Wangenheim requested sortie of the Goeben to Istanbul was rejected by the Kaiser on 2 August. ${ }^{262}$ But once Churchill seized the Sultan Osman-i Evvel and the Resadiye on 2 August, German Admiral Tirpitz ordered the Goeben and the Breslau to Istanbul. Tirpitz did not deploy the Mediterranean squadron to the Dardanelles just to protect the Ottoman Empire. Istanbul had agreed to the Treaty of Alliance on 2 August 1914 and Berlin wanted to show tangible support for Enver. Tirpitz also suggested offering Souchon's services to Istanbul along with additional naval personnel because since hostilities had commenced on 2 August, the prospects of the two ships transiting to secure waters were slight. Tirpitz had three choices: attempt to rush to Germany and risk encountering Entente naval units; flee to the Austrian base at Cato; or dispatch the vessels to Istanbul as requested by Wangenheim.

It appeared that the final decision was taken by Souchon himself. According to Tirpitz, on 3 August news was received of the Alliance with the Ottoman Empire, orders were sent to Souchon to attempt to break through to the Dardanelles. ${ }^{263}$ On 5 August the German Embassy at Istanbul reported that in view of the situation there, it was undesirable for the ships to arrive for the present. Thereupon, orders for the Dardanelles were canceled and Souchon, who was then coaling at Messina, Sicily, was directed to proceed to Pola or break out into the Atlantic. Later in the day, Austria, in spite of the pressure that Berlin was applying, refused to declare war on France or England and thus

${ }^{262}$ Mutius to Jagow, 2 August 1914, Berlin. In Montgelas, 505.

${ }^{263}$ Alfred von Tirpitz, My Memories (New York: Dodd Mead, 1919), 349-350. 
could not help Germany's Mediterranean Squadron. Under the circumstances, it was decided to give Souchon liberty to decide for himself which line of escape to attempt.

The Porte on 6 August, looked to strengthen the military position and clarify the relationship between Istanbul and the Alliance. In exchange for the Ottomans' allowing German and Austrian warships access to the Straits, Wangenheim agreed to abolition of the capitulations; support of Istanbul when dealing with Romania and Bulgaria; no peace while Ottoman territories were occupied by Entente forces; siding with Istanbul if war with Greece ensued; securing the lower Caucasus Region for Pan-Islamic goals; and ensuring appropriate war indemnity. ${ }^{264}$ Wangenheim accepted the agreement that formally assured the Ottomans tangible gains after victory if Istanbul entered the war on the Alliance side.

The Goeben and the Breslau arrived outside of the Dardanelles on 8 August 1914. Captain Hamann, Naval Attaché of the Germany Embassy in Istanbul, requested and six thousand tons of coal from the Ottoman Naval Minister, Djemal Pasha. Djemal agreed and was led to believe the coaling would take place outside of Ottoman territorial waters. The actions of the ruling junta in Istanbul concerning the arrival of Goebin and Breslau indicates that the ships were not expected. Djemal was made aware of the impending arrival of the Goeben and the Breslau while dining at the Grand Vizier's home. Enver granted permission for the warships to enter Ottoman waters without discussing the situation with the Council of Ministers, the nominal ruling body of the C.U.P. and thus

${ }^{264}$ Trumpener, 28. 
the Ottoman Empire. ${ }^{265}$

According to the rules of neutrality, the Ottomans were bound either to return the ships to the Aegean within 24 hours or to disarm and intern the ships and crews. ${ }^{260}$ The triumvirate ruling the Ottoman government--War Minister Enver Pasha, Minister of Marine Djemal Pasha, and Interior Minister Talaat Bey--along with Grand Vizier Said Halim, did not desire to send the two German warships to certain destruction by returning the ships to the Aegean. The alternative, that the ships be disarmed and the crews interned, was denounced by Ambassador Wangenheim. The dilemma the Ottomans faced was not wanting to antagonize the British into war when Istanbul was not prepared but not wanting to perturb an ally, Germany. ${ }^{267}$

The triumvirate decided that the ships would be disarmed and the crews interned. Talaat Bey and Ottoman Foreign Minister Halil Bey informed Ambassador Wangenheim, who refused to consent regardless of the consequences. When informed by German Chief of Staff Admiral von Pohl that the Goeben and Breslau were trapped and Kaiser Wilhelm instructed Souchon to use his own judgment. ${ }^{268}$

The plot to purchase the Goeben and Breslau seems to have been formulated at a meeting once Germany's position on the ships' fate was clear. On 12 August 1914

${ }^{26 s}$ Djemal, 118-119.

${ }^{266}$ Fenwick, 649 .

${ }^{267}$ Djemal, 119.

${ }^{268}$ Walter Görlitz, ed., The Kaiser and His Coum: The Diaries, Notes, Books and Letters of Admiral Georg Alexander von Müller, Chief of the Naval Cabinet, 1914-1918, trans. by Mervyn Savill (New York: Harcourt, Brace and World, Inc., 1959), 16. 
Ambassador Wangenheim was presented with the suggested sale. Wangenheim then communicated with Berlin and received a favorable response. The "sale" was agreed upon with the stipulation that Souchon be accepted into the Ottoman Navy. But no mention of the impending sale is found in ADM Georg Alexander von Muller's diaries. Such an event, the sale or transfer of Germany's Mediterranean Squadron to the Ottoman government, would have warranted at least a mention unless it had been planned ahead of time, or unless Souchon acted upon his own with the German foreign services' blessing.

The theory that the sale was planned ahead of time is unsubstantiated. The principal characters in both the Ottoman and German political and military circles have never alluded to such a scheme. The "sale" violated Article Fifty-six of the London Maritime Declaration of 1909 , which declared that the transfer or sale of merchant vessels after declaration of hostilities was null and void. Germany had agreed to the treaty but the Ottoman Empire had not ratified or adopted the declaration. ${ }^{269}$ The answers may lie in the choices open to the Admiral and in the Kaiser's instructions to Souchon to use his judgment. All options for Souchon were negative. Internment would mean loss of ships and having to sit out the war. Returning to the Dardanelles meant certain defeat unless the Austrians came into the Aegean Sea to assist in the battle with the British fleet waiting at the mouth. Movement into the Black Sea would mean a short deployment and ultimately failure due to lack of refueling and rearming facilities. "Selling" the ships allowed Souchon the opportunity to fight another day when the odds were more

${ }^{269}$ Sazonoff to Giers, 11 August 1914, St. Petersburg. In Scott, Vol. II, 1392-1393. 
favorable. Finally, any decision the Ottomans made had to take into account that German sailors still commanded the guns of the Goeben and the Breslau, and an unfavorable outcome could result in the shelling of Istanbul. ${ }^{270}$

The Goeben was a first-generation dreadnought capable of doing battle with anything the Russians possessed or would construct during the duration of the war. The Goeben had a length of 610', a beam of 97', main armament of 10x11", secondary armament of $12 \times 5.9^{\prime \prime}$ and $10 \times 3.4^{\prime \prime}$, with a gross tonnage of 22,640 and a speed of 27 knots. ${ }^{271}$ German naval engineers reviewing the results of Port Arthur and Tsu-Shima in order to increase survivability, added a 4,000-ton girdle and shifted coal bunkers to minimize damage from mines and torpedoes. ${ }^{272}$ The Breslau, a protected cruiser, had a length of 461 't, a beam of $45^{\prime}$, main armament of $12 \times 4.1$ ", a gross tonnage of 5587 , and a speed of 25 knots. ${ }^{273}$ The two ships operating in tandem with support from other Ottoman fleet units could project sufficient power to duel with the Russian Black Sea fleet. However, the supporting Ottoman units were in marginal states of readiness. Inadequate ancillary support from Ottoman capital ships prevented Souchon from achieving battle space domination in the Black Sea after 1916.

${ }^{270}$ Walder, 28.

${ }^{271}$ Güleryüz, 141-142.

272Dan van der Vat, The Ship That Changed the World (Bethesda, MD: Adler \& Adler, 1986), 39.

${ }^{273}$ Ibid., 150-151. 
The Ottoman government on 11 August 1914 informed the Allies of the purchase and of the reasoning behind it: the need for bargaining with Greece on equal terms. ${ }^{274}$ Dealing with Greece tended to be the underlining drive for warship possession, either purchased and built in England, as in Sultan Osman-i Evvel and Resadiye, or acquired from Germany, as in the Brandenburg-class battleships. Control of the Goeben and Breslau and makeup of the crews seems to have favored the Allies and not Germany. Grand Vizier Said Halim had requested Admiral Limpus and his staff to stay. Djemal agreed to remove the German crews in favor of sailors selected by Limpus and Djemal noted the two ships would not leave the Sea of Marmara so as not to provoke England or Russia. ${ }^{275}$

Admiral Ebergard understood that the strategic situation was unfavorable to Russia. The two German warships were in neutral waters and not interned. Ebergard proposed to exercise similar right of entry with the most powerful units the Russian Black Sea Fleet could muster. Russia could then demand that Istanbul order the German ships south to the Aegean Sea and the waiting English fleet or fight at point-blank range of the Bosporus. Such a fight would negate the long-range capabilities of the Yavaz, and the numerically superior Russian Fleet would have an advantage. Ebergard prepared the fleet at the same time informing the Russian Foreign Affairs Ministry. France and England refused to agree to the action, and the Russian Foreign Affairs Ministry scrapped the plan

${ }^{274} \mathrm{Mr}$. Beaumont to Sir E. Grey, 11 August 1914, found in Lumby, 433.

${ }^{275}$ Sir L. Mallet to Sir E. Grey, 18 August 1914, Istanbul, found in Lumby, 445. 
in the hope that Istanbul would remain neutral..$^{276}$

Istanbul did not fully control the Goeben or the Breslau, as is evident from the behavior of the two ships' crews. On 11 August the German crews boarded French and English merchant ships interned in the Dardanelles and destroyed communications equipment and seized supplies. ${ }^{277}$ The German crews' actions throughout August 1914 indicated Istanbul had little or no control whatsoever over Souchon or the warships and may have feared antagonizing the Germans by pressing the need to uphold neutrality laws.

The situation concerning the Goeben, renamed the Yavuz Sultan Selim (Yavuz), and the Breslau, renamed Midilli, became less favorable to the Allies when, on 14 August Limpus submitted a report to the Grand Vizier. The report concerned not only the manning of the Yavuz and the Midilli, but the political course that the Ottoman Empire should proceed to observe strictest neutrality. Limpus overstepped his authority by suggesting Ottoman political procedure and bypassed his civilian authority, the Ottoman Minister of Marine, Djemal. Additionally, the report was written in English. The Grand Vizier could read English; Djemal could not. Djemal reminded Limpus that his position in the Ottoman Empire was to assist the Minister of Marine and not offer unsolicited political opinions. Limpus apologized for exceeding his authority and requested leave to visit his daughter in Therapia. Djemal agreed to Limpus' appeal for leave but also

${ }^{276}$ George Nekrasov, North of Gallipoli: The Black Sea Fleet at War, 1914-1917 (New York: Columbia University Press, 1992), 20-21.

${ }^{27}$ Giers to Sazonoff, 12 August 1914, Istanbul. In Scott, Vol. II, 1393. 
pointed out that to avoid misunderstanding between the British advisors and Ottoman crews, the Admiral's staff should work out of the Marine Ministry while Limpus was in Therapia. ${ }^{278}$

On 16 August 1914, all the British advisors to the Ottoman Minister of Marine departed because Limpus removed his officers from Ottoman ministerial service. ${ }^{279}$ Djemal did not remove the British naval mission in favor of Souchon. Souchon became Commander-in-Chief of the Imperial Ottoman Fleet only after Limpus removed himself. The Germans filled the vacuum that the British created. Had Limpus stayed, he would have been the German Admiral's superior. Limpus was highly respected by Sultan Mehmet V, who regretted deeply England's decision to remove him. ${ }^{280}$

Germany now controlled the armed forces of the Ottoman Empire. General Limon von Sanders directed the army, and Admiral Souchon the fleet. Wangenheim understood fully that with Germans in charge of Istanbul's armed forces, the Porte would have to fulfill any treaty obligations and not renounce agreed upon commitments.

Wangenheim's implied scheme to enforce Ottoman compliance was stated in a telegram to German Foreign Minister Jagow before the war commenced. ${ }^{281}$

${ }^{278}$ Djemal, 121.

${ }^{279} \mathrm{Mr}$. Beaumont to Sir E. Grey, 15 August 1914, found in Lumby, 437. See also Giers to Sazonoff, 31 August 1914, Istanbul, found in Scott, Vol. II, 1412.

${ }^{280}$ Scott, Vol. 1I, 1123-1124.

${ }^{281}$ Wangenheim to Jagow, No. 371, 27 July 1914, Istanbul. In Montgelas, 242. 
London underestimated the reaction to the seizing of the battleships and moved quickly to correct Churchill's blunder. In order to ease Istanbul's concerns, Churchill proposed on 19 August an arrangement in which the Ottomans would have received at the end of the war either the two requisitioned dreadnoughts, fully repaired, or else their full value; and in either case Britain would pay Istanbul $\$ 4,860$ a day in weekly installments for every day the ships were kept. This arrangement would have come into force on the day when the last officer and man belonging to the Goeben and Breslau had left and would have continued as long as the Ottomans remained neutral. ${ }^{282}$ The Porte rejected the offer as being too little, too late. Souchon was appointed Commander-in-Chief of the Imperial Fleet on 17 August 1914. ${ }^{283}$

The offer from Churchill was not in the best interest of the Ottomans. England removed Limpus and, if Souchon left, the Ottomans would not have the technical expertise needed to manage such a diverse fleet. Also, unless some German specialist stayed, the Yavuz and the Midilli would quickly deteriorate, as witnessed by the two Brandenburgs. Removing Souchon and without some leadership for the first line of defense, would have invited aggression from a rapidly improving Russian Black Sea Fleet or the British-advised Greek fleet.

Any difficulties London had with Istanbul were created in London. The Ottomans desired to enter into a military agreement with London and Paris only to be rebuffed in

${ }^{282}$ Lumby, 427.

${ }^{283}$ Djemal, 122. 
favor of St. Petersburg. The Porte wished only to maintain the status quo and to have reaffirmed Ottoman sovereignty in the questionable regions of Egypt and the Aegean islands. The foreign policy of London towards the Ottomans and Islamic regions in general created ethical dilemmas for any Anglophiles in the Young Turk government. British naval officers still staffed the detested Greek navy. The seizure of the two dreadnoughts and the desperately needed ammunition for the Dardanelles forts, all paid for in advance, shifted public opinion away from anything British. The general belief was that England could have stopped Italian and Greek seizures of Ottoman territory and the subsequent massacre of Muslims if London had wished. Additionally, England refused to remove warships from the Shatt-el Arab waterway after the Porte provided copies of the Turco-British Declaration of 29 July 1913, which specified the delineation of Ottoman sovereignty. The Porte wished only to maintain neutrality and the status quo..$^{284}$

Religion is also believed to have been a part of Britain's foreign policy towards the Ottoman Empire. England controlled India and Egypt, both with large Muslim populations. The Ottomans believed that England wished to control the personage of the "Chalif of Islam." 2855 The British Admiral Fisher knew that England need the Ottoman Empire in order to supply Russia and because of the influence of Islam. He preferred to

${ }^{284}$ Sir L. Mallet to Sir E. Grey, Istanbul, 12 October 1914. In Scott, Vol. II, 11261127.

${ }^{285}$ Djemal, 112. 
have the Ottomans on England's side and avoid a religious fight. ${ }^{286}$

With Souchon in control of the Ottoman navy, German specialists replaced English advisors, and operational control became mostly German. On 30 August 1914 Admiral Guido von Usedom arrived and began the rebuilding of the Dardanelles defenses. German shipyard workers arrived and repairs were started on fleet units. The dismal state of readiness was highlighted in Ottoman papers. The blame was placed squarely upon the British. Anti-British propaganda became rampant throughout Istanbul, and Anglophiles became scarce.

On 27 September Sir Louis Mallet, the British Ambassador in Istanbul, was reported to have gone to the Sultan himself to offer the return of the two ships. The British were slow in realizing the level of discontent that materialized in the Ottoman Empire over the two popularly subscribed ships. ${ }^{287}$ The two dreadnoughts were needed by the Royal Navy, but future delivery of new construction could allow the warships' return to Ottoman control. Returning the ships could diminish the uproar over the seizure and remove the major grievance used by Enver to incite the Ottoman populace against the Entente. Restoration of the two ships could also encourage Djemal and the Grand Vizier to advocate a proactive neutrality. Sultan Mehmet V, being a constitutional sovereign, could not comment on the Mallet suggestion, opting to consult with the government. Suggesting to return what was rightfully Ottoman property, and requiring complete

${ }^{286}$ Marder, 26.

${ }^{287}$ Frank G. Weber, Eagles on the Crescent: Germany, Austria and the Diplomacy of the Turkish Alliance 1914-1918 (London: Cornell University Press, 1970), 79. 
neutrality, was not in Istanbul's interest. The Ottomans recognized that for the Empire to be protected from schemes of partition, the Empire had to insist on intervention. A successful conflict could redraw the map in the Balkans and eastern Anatolia. Being on the winning side could also protect Muslims residing in territories adjacent to the Ottoman Empire. A military triumph over a European Christian consortium, be it the Entente or the Alliance, would reaffirm Ottoman leadership in the Islamic world. The Porte declined the offer from Ambassador Mallet. By late September Souchon began to conduct Black Sea interdiction sorties, hoping to encounter the Russian Black Sea fleet and creating the causation for war.

The desire for dreadnoughts was not just an Ottoman lust for supremacy against the Empire's enemies. Supremacy over both Russia and Greece was hopeless, but parity was not. A review of dreadnought acquisitions in the Ottoman region from 1909 to 1917 shows clearly that Istanbul sought out capital ships to offset its traditional enemies, Greece and Russia. Had Athens and St. Petersburg not acquired such assets, Ottoman ship acquisition patterns indicated Istanbul would not have expended such funds. Ottoman shipbuilding and overseas purchases prior to 1910 favored coastal craft rather than capital ships. The acquisition of smaller ships allowed for coastal defense and protection of an empire under creeping territorial violation. Smaller ships also doubled for smuggling interdiction and revenue enforcement. Finally, smaller ships could be serviced in existing Ottoman yard facilities. Capital ships were too expensive an asset to hazard in battle, to operate in peace, and to use for revenue protection. Table 17 clearly shows that Ottoman capital ship acquisitions were fueled by adversarial procurement of such assets. 


\section{CAPITAL SHIP ACQUISITION}

Greece/Russia

1909

Averoff bought (October)

1910

I-Oann Zlatous (Russia) (June)

Evastafij (Russia) (June)

Greek attempts to buy French

battleships (November)

1911

1912

Greece attempts to buy Argentine

battleships (September)

Salamis ordered (July)

1913

Greek attempts to buy Rio de Janeiro (November)

1914

Russia negotiates to purchase

Chilean and Argentine battleships

(January)

Greeks order Lorraine class from

France (March)
Resadiye ordered (June)

Mahmud Resad V (June)

\section{The Ottoman Empire}

Barbados Hayreddin/Torgud Reis (September)

Mahmud Resad V (canceled) (June)

Rio de Janeiro bought (January) 


\section{TABLE 17 (CONTINUED)}

American shipbuilder negotiates to sell five battleships to Greece (April)

Idaho/Mississippi bought (Greece)

(July)

1915

Imperatrica Marija (Russia) (July)

Imperatrica Ekaterina Velikaja (Russia) (October)

1916

1917

Volya (ex-Imperator Aleksandr III)

(Russia) (June)
Faith ordered (April)

Goeben/Breslau arrived (September) 
Fueling the race for capital ships were Russian Black Sea plans drawn up by Russian Vice Admiral lvan K. Grigorovitch, Russian Minister of Marine. In April 1911 Grigorovitch had laid down a naval budget calling for a Black Sea fleet one and one-half times the combined forces of Bulgaria, Romania, and the Ottoman Empire. Additionally, the Russian Duma approved funds for an accelerated Black Sea construction program in April 1914 in order to counter the two Ottoman dreadnoughts building in England.

The accelerated Russian Black Sea construction, along with the Greek acquisition of the two American battleships, found the Ottomans surrounded by well-armed belligerents. To counterbalance the threats, two modern dreadnoughts had been painstakingly purchased via public subscription: not for offensive but defensive purposes. Neither Greece nor Russia had legitimate fears from the C.U.P. regime. However, the Ottoman Empire had experienced wholesale slaughter of Muslims and seizure of territory from both Russia and Greece, and thus it had genuine concerns.

The acquisition of capital ships for most countries involved nationalistic ambitions more than actual security. For the Ottoman Empire, capital ships were an assurance against unchecked waterborne aggression. Battleships provided a level of security not found with fixed fortifications. Enemies plan strategies to avoid or confront battleships, and having such assets can prevent wars if utilized correctly. The Ottomans needed the Sulran Osman-i Evvel and Resadiye to confront Greek aggression. The Ottoman citizenry paid for the ships in the belief the vessels would prevent future massacres of Muslims by Christians. The ships were not delivered, and the fear became reality. 


\section{CHAPTER V}

\section{NAVAL AVIATION AND SUBMARINES}

Ottoman Naval Aviation officially began in May 1915 by order of Enver Pasha, the Ottoman War Minister and acting Minister of the Marine. Using assets of the German naval unit covering the Dardanelles, a seaplane base was constructed near the Ottoman Army Air station of San Stefano on the shore of the Sea of Marmara. Six seaplanes were ordered, and six Ottoman naval officers were sent to Wilhelmshaven in Germany for instruction. Additionally, pilots and observers began to train at San Stefano in order to augment German naval units in-country. Ottoman naval assets made only token appearances during the Dardanelles battles because the pertinent tasks were carried out by the more established Ottoman Air Force..$^{288}$

The basic task of naval aviation during World War I was observation. The need for intelligence on enemy ship movements, concentrations, and operations and on seeding of new or established minefields was vital in order to protect both the coastline, and the waterborne commerce essential to waging war.

The Ottomans were fully aware of the possibilities of aircraft in warfare. During the Italo/Ottoman War, Italian ground forces were served with good intelligence from airplanes, and the experience was not lost on the Ottomans. The Hague convention of 
1899 forbid bombing from balloons but Italy contended that planes were exempt and utilized Swedish grenades to attack the Senusi whenever possible. ${ }^{289}$ During the Balkan wars, the Ottomans utilized French-built Deperdussin monoplanes for intelligence and forward gunfire observation. The Ottomans did not have trained pilots and were forced to utilize the services of an international band of civilian pilots. The foreign pilots were employed by the Ottoman "Administration for War Flying." ${ }^{290}$ The use of air power against civilian targets accrued when the Bulgarians dropped thirty bombs over Adrianople in one day and killed or injured six persons. ${ }^{291}$ The Ottomans, in an attempt to limit the possible danger from Balkan allies' planes, let it be known that any enemy pilot captured would be shot regardless. This threat to shoot downed pilots seems to have been a factor in the practice of some Balkan pilots not to drop anything other than paper leaflets. $^{292}$

Prior to World War I, the Ottoman Minister of Marine, Ahmad Djemal Pasha, contracted with the French government for Newport seaplanes and twelve instructors. This contract was canceled upon the outbreak of war. ${ }^{293}$ The French would use the

${ }^{28}$ Bill Gunston, ed., Chronicle of Aviation (London: Chronicle Communication, Ltd., 1992), 28.

${ }^{200}$ Kennett, 18.

${ }^{291}$ The Times History of the War, Vol. II, 182.

${ }^{292}$ Cross and Cockade, 103.

${ }^{293}$ Djemal, 162. 
Ottoman purchased planes against Istanbul in the Dardanelles Campaign. ${ }^{294}$ Shortly after the landing of the Anglo-French troops at Gallipoli on 25 April 1915, the Special Command of the Imperial German Navy in the Ottoman Empire requested seaplanes for the Dardanelles front. The mission of the aircraft would be observation of allied fleet units and islands occupied by the Anglo-French forces. Ottoman Air Force planes had been concentrating on harassing flights over the beach head but lacked the technical skills of observation. The Rumpler and Albatross B-type planes initially pressed into service at the outset of war were inadequate for intelligence flights because of short operational range.

The German Imperial Navy Department complied with the request and sent three 100 h.p. Gotha seaplanes to Istanbul. Because Bulgaria was neutral, the planes were shipped via railway to Czernaheviz in Hungary, assembled, flown clandestinely to Lom Palanka in Bulgaria, and reshipped by railway to Istanbul. By the end of July 1915, an independent seaplane unit of the German Imperial Navy in the Ottoman Empire was formed using volunteer civilian Gotha mechanics, Ottoman sailors, and mixed German/Ottoman plane crews. The commanding officer was Kaptain-Leutenant Liebmann, who answered to the Governor General of the Straits, Admiral Guido von Usedom of the Imperial German Navy. The headquarters of the unit was in Yesilköy. The insignia used by Imperial German Naval seaplanes was the German Iron Cross. Ottoman naval seaplanes utilized not the Star and Crescent, as found on Ottoman

${ }^{294}$ R.D. Layman, Before the Aircraft Carrier: The Development of Aviation Vessels, 1849-1922 (London: Conway Maritime Press, 1989), 18-19. 
contracted planes in the Balkan wars, but a black square with a white border. The rationale for the change is not clear.

The German naval seaplane unit became the mentor for the Ottoman naval unit. The future Ottoman naval pilots "cut their teeth" shadowing German naval pilots. Ottoman sailors worked with German naval plane crews until a sufficient number of planes arrived to allow for all-Ottoman units. The Ottoman/German naval air units developed active and successful operations during the Dardanelles battles in spite of limited numbers and the technical defects of the aircraft. The aircraft transferred to the Dardanelles theater were stationed at Chanak-Kale on the south shore of the Sea of Marmara. Once operational, the units were still under the overall control of Usedom. The first operational flights revealed that the 100 h.p. Gotha seaplanes were unsuitable for long-range reconnaissance. Seaplanes were heavier than land based planes because of the pontoons and the additional weight increased wind resistance and reduced speed. Also, the 100 h.p. Gotha seaplane was woefully underpowered and had a maximum altitude of 1000 meters. The combination of slow speed and low ceiling resulted in severe gunfire damage. To avoid further casualties and unnecessary damage, naval reconnaissance during the Dardanelles campaign was limited to night operations. ${ }^{295}$ Reconnaissance undertaken during moonlit nights yielded usable information with less danger to the pilots. Ships could be counted, identified and located with little real threat of harm. As proficiency improved among both German and Ottoman crews, night 
contracted planes in the Balkan wars, but a black square with a white border. The rationale for the change is not clear.

The German naval seaplane unit became the mentor for the Ottoman naval unit. The future Ottoman naval pilots "cut their teeth" shadowing German naval pilots. Ottoman sailors worked with German naval plane crews until a sufficient number of planes arrived to allow for all-Ottoman units. The Ottoman/German naval air units developed active and successful operations during the Dardanelles battles in spite of limited numbers and the technical defects of the aircraft. The aircraft transferred to the Dardanelles theater were stationed at Chanak-Kale on the south shore of the Sea of Marmara. Once operational, the units were still under the overall control of Usedom.

The first operational flights revealed that the 100 h.p. Gotha seaplanes were unsuitable for long-range reconnaissance. Seaplanes were heavier than land based planes because of the pontoons and the additional weight increased wind resistance and reduced speed. Also, the 100 h.p. Gotha seaplane was woefully underpowered and had a maximum altitude of 1000 meters. The combination of slow speed and low ceiling resulted in severe gunfire damage. To avoid further casualties and unnecessary damage, naval reconnaissance during the Dardanelles campaign was limited to night operations. ${ }^{295}$ Reconnaissance undertaken during moonlit nights yielded usable information with less danger to the pilots. Ships could be counted, identified and located with little real threat of harm. As proficiency improved among both German and Ottoman crews, night 
bombing raids using twenty-two-pound bombs manufactured in theater were dropped on enemy airfields on Imbros and Tenedos. Bombing runs over ground targets invited indiscriminate rifle and machine gun fire and the slow speed and low altitude necessitated for night vision allowed Allied forces the opportunity to fire on the sound of the engine. This resulted in gunfire damage to the seaplanes and injuries to pilots.

The typical "unit" of the Ottoman Air Force and Naval Aviation was comprised of six pilots. Small "sections" of four pilots were also formed. Fighters comprised most of the "units," while seaplanes made up many of the "sections." At the start of the Gallipoli campaign, the Ottoman Air Force and Naval Aviation was badly outnumbered. Table 18 shows the balance of air assets at noted dates. The German-Ottoman air assets (air force and naval) were always outnumbered but not out-fought. By November 1915 four German Fokker aircraft had arrived via the "Orient Express" now that Bulgaria had joined in with the Central Powers. The Fokker fighters were far superior to anything the AngloFrench air units possessed. The superior aircraft would result in Captain Shakir Feyzi of the Ottoman Air Force, also the Chief of Staff of the Ottoman Air Force, achieving "ace" status prior to his death on 5 May $1916 .^{296}$

The aggressive nature of the Ottoman pilots in both the Air Force and Navy may be attributed to the threat posed by the British Short Type 184, twoseater seaplane. On 12 August 1915 a British Short from the HMS Ben-My-Cherry, piloted by Lieutenant C.H. Edmunds sank the stranded Mahmut Sevket Pasa off Dogan Aslan in the 
TABLE 18

\section{AIR ASSETS IN THE OTTOMAN THEATER}

\section{English}

\section{Ottoman}

\section{$\underline{18 \text { March } 1915}$}

1 short seaplane

2 Wight seaplanes

1 unarmed Albatross

2 Sopwich seaplanes

2 Sopwich tabloids

TOTAL: 5

\section{TOTAL: 1}

\section{May 1915}

18 Sopwich tabloids

3 Gotha seaplanes

3 Albatross

2 Wight seaplanes

2 Sopwich seaplanes

8 Maurice Farmans

1 Kite-balloon

TOTAL: 32

TOTAL: 6

\section{$\underline{6 \text { August } 1915}$}

6 Morane Parasols

17 Albatross (combat)

6 B.E. 2c biplanes

6 Caudron biplanes

3 Gorth seaplanes

4 Bristol Scouts

2 short two-seater seaplanes

2 Wight seaplanes

2 Sopwich seaplanes

8 Maurice Farmans

18 Sopwich tabloids

TOTAL: 54

TOTAL: 20

Source: Bryan P. Flanagan, ed., "The History of the Ottoman Air Force in the Great War: The Reports of Major Erich Serno," Cross and Cockade Journal, Vol. II, No. 2 (Summer 1970), 116. 
Dardanelles with the first-plane delivered torpedo in history. ${ }^{297}$ British plane-delivered torpedo attacks occurred until Ottoman air assets could combat the Shorts. ${ }^{298}$ AngloFrench land planes flew from ships and bases on Imbros and Tenedos, which necessitated a round trip for the Anglo-French planes and reduced the lingering time over the beach head. British Shorts carrying torpedoes had even less lingering time because of the weight and drag of the weapon. Ottoman pilots combating both torpedo-carrying planes and ground-attack aircraft flew from relatively close bases, allowing quick response to attacks with minimum use of fuel. When Allied planes had to return to Imbros or Tenedos because of fuel consumption, the flight to base presented an ideal opportunity for Ottoman attacks, for Allied planes could not waste fuel dueling.

The English utilized several ships for seaplane operations. The French also utilized seaplanes from both French and English ships. Unlike Ottoman naval seaplanes, the Anglo-French seaplanes were utilized in the combat mode more often than the reconnaissance or gunfire support aspect. English seaplane tenders are found in Table 19. ${ }^{299}$

With Bulgaria allied with the Ottomans, delivery of delayed aircraft accelerated and newly trained Ottoman Navy pilots were directed to fly Gotha seaplanes back to Istanbul via the Danube River. The flight facilitated pilot training and sped

${ }^{297}$ Gunston, 128.

${ }^{298}$ Kennett, 201-202.

${ }^{209}$ Parks, passim; and Gardiner, 64-67. 
TABLE 19

ENTENTE SEAPLANE TENDERS IN THE DARDANELLES

Name

(UK) Ben-My-Chree

(UK) Empress

(UK) Raven

(UK) Anne

(UK) Ark Royal
Built

1908

1906

1882

NA

1914
Tonnage

3888

2540

4678

7000

7450
Speed

24

21

10

11

11
Planes

4

6

2

2

6-8

Source: O.J. Parks and Maurice Pendergast, eds., Jane's Fighting Ships, 1919 (London: Sampson Low Marston, 1919; reprint, New York: Arco Publishing Co., 1969), passim; and Robert Gardiner, ed., Conway's All The World's Fighting Ships 1906-1921 (London: Conway Maritime Press, 1985; reprint, London: Conway Maritime Press, 1992, 64-67.

seaplane delivery.

Combat operations for the Ottoman Naval Air Service consisted primarily of reconnoitering of known Allied assets. As the Allies began to press the offensive at Gallipoli, the English and French submarines infiltrated the Sea of Marmara. Repeatedly, enemy submarines were tracked down and attacked with bombs and small arms fire. Up to July 1915 Allied submarines had free reign over the Sea of Marmara. Submarine tactics in World War I dictated surface cruising even in daylight, with underwater attacks only when stealth was required. Allied attacks upon commercial shipping were in most part gunnery practice since torpedoes were expensive and unreliable, the use of deck guns was the preferred method of attack. With Ottoman Air Force and later Naval Aviation Gotha WD2 flying reconnaissance over the Sea of Marmara, the Allies' nonchalance cruising was over. 
In order to facilitate anti-submarine flights, a airbase was established in October 1915 near Rodosto on the northern shore of the Sea of Marmara, halfway between Chanak-Kale and Istanbul. A fueling and munitions depot was set up on the Marmara island of Kuteli. ${ }^{300}$ The overflights harassed Allied submarines so that by January 1916 Anglo-French commanders suspended submarine operations in the Sea of Marmara. ${ }^{301}$

The success Ottoman Naval Aviation had at frustrating Allied submarine attacks is remarkable considering the Ottoman planes lacked radios to coordinate attacks and munitions adequate for combating submarines. However, the twoseater Gotha provided small arms fire and a relatively reliable platform for offensive action. The fear of unacceptable losses along with diminishing returns brought the Anglo-French underwater offensive to an end by December 1915.

During the Gallipoli operations, Russian Black Sea ships and aircraft harassed the Bosporus Strait and Ottoman naval commanders erected a seaplane base at Anatoli Kawak to provide reconnoitering of Russian forces. But with Gallipoli being contested, Ottoman Naval Aviation could only divert two 100 h.p. Gotha seaplanes to use for observation. The Russian Naval Aviation assets in the Black Sea consisted of seaplanes and flying boats. Flying boats have a longer range than seaplanes and can operate in inclement weather as well as rough seas. The Ottoman Navy had no flying boats. Russia also possessed seaplane tenders capable of projecting reconnoitering over the horizon.

${ }^{300}$ Cross and Cockade, 114.

${ }^{30 !}$ Güleryüz, 44. 
This capability allowed for advance warning of enemy movements, anti-submarine duties, offensive combat patrols, guidance through minefields, and forward gunfire observations. Table 20 lists the seaplane tenders utilized by the Russian Black Sea Fleet during the war.

Russian seaplane tenders provided support service to flying boats and seaplanes while conducting operations at sea. They were utilized extensively for combat operations in and around the Ottoman coaling center of Zonguldak. But once Russian Army objectives ruled out a serious amphibious landing after the Gallipoli fiasco, and no feint towards Istanbul was planned, Russian seaplane tenders were left with shipping interdictions and coastal bombardments.

In the summer of 1916 the German/Ottoman Naval Aviation assets began to concentrate on the Black Sea. With Gallipoli a success and the Dardanelles relatively secure, the Bosporus became the prime area of concern. The Ottoman naval assets for the Black Sea consisted of twelve 150 h.p. Gotha seaplanes with rearward firing machine guns. The greatest threat to the Ottoman Navy in the summer of 1916 was mines because The Russian Navy mined extensively during the war. Table 21 shows the Russian mining campaign carried out against the Ottoman coast. To counter fixed and floating offensive mines, Ottoman seaplanes were utilized to locate fields for minesweeping and to facilitate safe egress for Ottoman fleet units.

To protect colliers from Russian mines laid at Zonguldak, a new Ottoman Naval air station was erected first at Zonguldak and then moved to Eregeli. Ottoman Naval Air assets were vital to protect the Istanbul-Zonguldak route for colliers and seaplanes 
TABLE 20

RUSSIAN BLACK SEA SEAPLANE TENDERS

\begin{tabular}{|c|c|c|c|}
\hline $\begin{array}{l}\text { Name } \\
\text { Seaplanes }\end{array}$ & Built & Tonnage & Speed (knots) \\
\hline Aleksandr I & 1913 & 9200 & 15 \\
\hline Almaz & 1903 & 3285 & 19 \\
\hline Nikolaj I & 1902 & 3285 & 19 \\
\hline
\end{tabular}

Romanian flagged ships utilized seaplane tenders after Romania entered the war on 27 August 1916.

$\begin{array}{lllll}\text { Regele Carol I } & 1898 & 2369 & 18 & 4 \\ \text { Romania } & 1904 & 3159 & 18 & 4-7 \\ \text { Imperator Traian } & 1907 & 3418 & 18 & 4-7 \\ \text { Dacia } & 1907 & 3418 & 18 & 4-7\end{array}$

Source: René Greger, The Russian Fleet, 1914-1917 (London: Ian Allan Ltd., Shepperton, Surrey, 1972), 77; and Robert Gardiner, ed., Conway's All The World's Fighting Ships 1906-1921 (London: Conway Maritime Press, 1985; reprint, London: Conway Maritime Press, 1992), 64-67.

TABLE 21

RUSSIAN OFFENSIVE MINING FIGURES

$\begin{array}{llll}1914 & \underline{1915} & \underline{1916} & \underline{1917} \\ 1247 & 58 & 2187 & 2186\end{array}$

Source: René Greger, The Russian Fleet, 1914-1917 (London: Ian Allan Ltd., Shepperton, Surrey, 1972), 70. 
attacked and harassed Russian minelayers, blockaders, seaplane tenders, and submarines. This air protection would be extended to the Varna/Constanta theater area in late 1916.

The Ottoman defensive positions in the Caucasian region along the Bejuk-Dere River proved to be essentially invincible to Russian ground attacks. In order to create a pincher movement, Russian troops disembarked at Atina on 4 March 1916. The landing was accompanied by two seaplane tenders utilizing twelve "Russian hydroplanes." The seaplanes also supported the follow-up Rize landing on 7 April that would lead to the fall of Trebizond on 18 April $1916 . .^{302}$

Ottoman naval operational tempo in the Dardanelles wound down because of the decreased threat from the Anglo-French forces. In order to divert Allied warships away from the Palestine theater, on 20 January 1918 the Yavuz and Midilli sortied down the Dardanelles channel. The task of searching for a safe route through the minefields and identifying enemy contacts fell to the Ottoman seaplanes. The Yavuz and Midilli attacked and sank the British monitors M28 and Raglan at Kusu Bay. ${ }^{303}$ During the return trip, the Midilli ran into a minefield and sank. While return to the Dardanelles, the Yavuz was attacked by British land planes from Imbros and was damaged by two contact mines.

\section{${ }^{302} I b i d, 53-54$.}

${ }^{303}$ The Raglan was armed with two 14"/45 caliber Bethlehem guns originally designed for the Greek battleship Salamis. The three other twin turrets for the Salamis would be utilized on the British monitors Abercrombie, Havelock, and Roberts. All four monitors would take part in shelling Ottoman positions on the Dardanelles. Churchill originally named the monitors General Grant (Havelock), Admiral Farragut (Abercrombie) and Stonewall Jackson (Roberts), and Robert E. Lee (Raglan) to commemorate their U.S. origins. However, political concerns over a flagrant breach of American neutrality necessitated the changing of names. See Gardiner, 43-44. 
Ottoman seaplanes, along with Ottoman Air force units, held off the British air attack while the Yuvaz hobbled to port. On the return trip, the Yavuz ran ground at Nara Bank and was subjected to five days of relentless air attacks. The British launched 276 flights against the grounded Yavuz, marking the first deliberate air attack upon a battleship. ${ }^{304}$ But an aggressive Ottoman air counterattack successfully prevented all but two bombs from hitting the Yavuz. ${ }^{305}$ The Yavuz freed itself on 26 January 1918 and made for Istanbul.

Ottoman Naval Aviation began to expand from mine clearance to bombing operations in the spring of 1918. On 2 April 1918, five 200 h.p. Friedrichshafen seaplanes, armed with 60 kilogram bombs, mounted a night mission to Tenedos. Another raid occurred on 26 May 1918 against the flying field at Imbros. A daylight raid on 1 June 1918 by six seaplanes with bombs and incendiaries on the radio station and military complex on the island of Mavro was also successful. From July to September, Ottoman seaplanes attacked military objectives on Lemnos, Imbros, and Thasos using both day and night time attacks. The up-tempo of operation indicate the expertise of Ottoman pilots had increased to a level where the traditional defensive role of Naval Aviation was supplanted by offensive bombing. ${ }^{306}$

In the Ottoman theater of combat, ancillary units existed that supported Ottoman aviation or the general war efforts. Such units included German "Pascha" units, weather

${ }^{304}$ Huvgaard, 241.

${ }^{305}$ Cross and Cockade, 346-347.

${ }^{306}$ Cross and Cockade, 357. 
service and balloon units. The German Army in Palestine requested air assets from Berlin and received support in the form of "Pascha" units. Unlike the Ottoman Air Force, German Air Force, or the Ottoman Naval Aviation-German Naval Aviation, where Istanbul had some control, "Pascha" units were completely under Germany control. Since these units were outside Ottoman control, "Pascha" units are not included as Ottoman assets.

In order for planes to be fully utilized with the greatest possible chance of success, a weather service was erected in Istanbul. The service was run by Professor Dr. Weichmann with stations dispersed over the entire Ottoman Empire. However, because of the incomplete telegraph system, the weather service could not deliver the expected reports. The Ottomans also utilized dirigibles for offensive and defensive action. The Germans ordered airship number ten, stationed in Jamboli, Bulgaria, to support a bombing raid on Batum. The airship was dependent on weather service from Istanbul but because of mechanical problems, the airship was unable to receive weather notices. The airship never bombed Batum, and the exact cause of the loss of airship number ten is unknown. ${ }^{307}$ The Ottoman Air Force did utilize balloons for both observation and weather. The balloons were stationed on the Bosporus, the Dardanelles, and at Istanbul.

By 1 January 1917, the Ottoman Naval Air arm consisted of one full squadron of eight planes, all manned and crewed by Ottoman Naval personnel stationed at Izmit. Individual planes were stationed at Anadoluhisari on the Bosporus and Eregli or the 
Black Sea. ${ }^{308}$

Attrition from constant warfare since 1911 had depleted the resources of the Ottoman Empire so that by September 1918 the end was near. Lack of parts, fuel and replacement aircraft limited the Ottoman air assets, both Navy and Air Force, to infrequent flights of little military value. But war provided the Ottoman Navy pilots and crews with valuable knowledge and experience gleaned from almost five years of air warfare. In that five years, the Ottoman Navy Air Service utilized some thirty seaplanes, maintained bases at Eregli, San Stefano, Kuteli, Chanak-Kale, and Anatoli Kawak, and held the major industrial Allied Powers at bay.

This action could not have happened without German assistance. The total aid from Germany to the Ottoman air forces, both Air Force and Navy, is found in Table $22 . .^{309}$

During the war, Ottoman-German pilots downed twenty-eight enemy aircraft, sixteen in the Asia Minor-Dardanelles theater of operations. The tempo of the war exhausted the Ottoman Army but not the air services. Had parts and resources been available, the facts indicate that the pilots and crews would have continued prosecuting the air war.

The Ottoman air services resembled German air service because of the efforts of German Captain Erich Serno, who created the infrastructure and support services in

${ }^{308}$ Cross and Cockade, 364.

${ }^{300}$ Cross and Cockade, 365. 


\section{TABLE 22}

\section{GERMAN AID TO OTTOMAN AIR ASSETS}

\section{$\underline{\text { Planes }} \quad \underline{\text { Pilots }} \quad \underline{\text { Technicians }}$}

$\begin{array}{lrrr}\text { Air Force } & 230 & 100 & 220 \\ \text { Navy } & 30 & 25 & 80 \\ \text { Pascha } & \underline{155} & \underline{190} & \underline{1,440} \\ & & & \\ \text { TOTAL } & 415 & 315 & 1,740\end{array}$

Source: Ryan P. Flanagan, ed., "The History of the Ottoman Air Force in the Great War: The Reports of Major Erich Serno," Cross and Cockade Journal, Vol. II, No. 2 (Summer 1970), 364.

order to facilitate the growth of Ottoman air assets. He found local Turkish craftsmen to augment German technicians and created parts. It was Serno who requisitioned Austrian air force mechanics and then found Anatolian Bazaar craftsmen skilled enough to fabricate propellers. The resolution of Serno, coupled with both Ottoman and German assistance, created air forces second only to the most advance industrial powers. The Ottoman Naval Aviation Corps during the war was always outnumbered, outgunned, and outspent, but not outfought. Innovative tactics and aggressive zeal overcame all but the complete exhaustion of the Sublime Porte.

\section{Submarines}

The Ottoman Navy had no submarine assets from 1889 until the capture of a French submarine in October 1915. However, the attempt to create a submarine force was evident when Ottoman naval authorities experimented with cutting-edge firstgeneration submarines in 1886, several years before the United States Navy took 
undersea warfare seriously. Naval plans drawn up directly after the Balkan wars called for a submarine force of four craft. Revised naval programs drawn up during the world war envisioned a submarine force of twelve craft.

The acquisition of submarine forces capable of defending the empire was not beyond the scope of Ottoman planners. The Porte followed naval plans drawn up by British advisors and submarines were not called for in any plan put forth by admirals Gamble or Williams but the first submarines acquired Ottoman Empire was driven by the British. The first submarine that the Ottoman Navy acquired was a Nordenfeld-designed craft. Thorsten W. Nordenfeld, a Swedish gun expert, designed a submersible craft in 1885. He built upon a design by the Reverend George Garrett. Garrett was by profession a priest in the Church of England but also the father of British submarines.

Garrett's craft utilized a coal-fired, steam-driven engine on the surface. For underwater propulsion, hot water was stored in tanks forward. Heat exchange from mechanical energy was provided via a Lamm's fire-less locomotive engine. In a Lamm engine, latent heat is siphoned off pressurized boiled water. The pressured boiled water was also utilized as reserve buoyancy. The use of a coal-fired boiler for surface operation, along with the latent heat exchange while underwater, gave the submarine up to five hours of operations and a top speed of three knots and a range of twenty miles.

Nordenfeld improved Garrett's craft by installing two vertical propellers driven by a six h.p. steam engine that was automatically shut off by hydrostatic valves at a selected depth. The craft carried at first a locomotive torpedo but later two Whitehead $356 \mathrm{~mm}$ in external discharge tubes were added, along with two $35 \mathrm{~mm}$ Nordenfeld machine guns. 
The Nordenfeld craft had three modes of operation. the first was fully on the surface, where the craft could use the coal-fired boiler for propulsion and the machine guns and torpedoes for attack. The second mode of operation was partially submerged. In this mode, all but the conning tower was under water. This allowed use of the coal-fired boiler for propulsion and the torpedoes for action, but, the machine guns were not available and sea conditions greatly influenced the success in the partially submerged mode. The last mode was the submerged mode. In this mode, propulsion was derived from the Lamm's latent heat exchange engine, resulting in speed sensitive to sea conditions. The use of machine guns was lost, but the torpedoes were available. In all three modes, stocking a coal-fired boiler and storing several tons of heated water in steel tanks created an internal environment quite hot.

Nordenfeld's first craft was built in Sweden and sold to Greece in 1886. The Ottoman Navy acquired Nordenfeld's next two craft. The Ottoman Navy purchased from Des Vignes, Chertsey, England, two "Denizalti," or submarines of Nordenfeld design, on 23 January 1886. The craft were delivered in sections and assembled by the Tersane-i Amire Naval Shipyard at Istanbul. Launching was 9 June 1886 for the Abdul Hamid and 8 April 1887 for the Abdülmead. Abdul Hamid's trials on the surface were successful, accumulating in a sixty N.M. trial run to Ismid but submerged tests proved the stabilizing system a failure. Abdülmead was nicknamed the "whale ship" and there were not enough volunteers for the crews, and both boats were laid up in the naval arsenal at Kasimpasa by 1889 and allowed to deteriorate. The submarines were discovered by the Germans in 
early 1915 , but attempts to make the craft operational failed. ${ }^{310}$ The pair would be scrapped by 1921 .

The Nordenfeld was a first-generation submarine with all the developmental flaws inherent in evolving technology. Additionally, the current in the Bosporus Straits (four to five knots) would make any craft unable to maintain at least five knots submerged inherently dangerous. A follow-on craft mounting internal torpedo tubes and an upgraded power plant were sold to Russia after an impressive demonstration at the Naval Review of 1887 but the craft foundered en route to St. Petersburg in 1887 and was later scrapped.

The race to acquire submarines was initiated by Greece in $1885 .{ }^{311}$. The Ottomans, possibly fearing Greek intentions, purchased two in order to combat Greece's one. This left the Russians, possibly fearing an imbalance of power in the Black Sea, purchasing the latest model on the market. The purchase of the first Nordenfeld by Greece set in motion the naval race in the Aegean-Black Sea region that would not end till the Treaty of Lausanne in 1923.

Ottoman naval plans after the Balkan wars called for a large force of surface ships. The naval force envisioned by Admiral Williams, British advisor to the Ottoman Minister of Marine, called for no submarines. Yet, four submarines were requested. Inasmuch that submarines were ordered indicated influence from some third party,

${ }^{310} \mathrm{Gardiner}, 160$.

${ }^{31}$ Hovgaard, 284. 
possibly German Major von Stremple, an advisor to the Ottoman Army. Major Stremple was instrumental in creation of the Ottoman Navy League. The Ottoman Navy ordered two submarines from Vickers Ltd at Newcastle-upon-Tyne in England on 29 April 1914. An additional pair of submarines was ordered from Schneider and Cie at Chalons-surSaone in France on 30 April 1914. With the commencement of hostilities, the French canceled the orders and cleared the blocks. England requisitioned the two submarines at the same time that London seized the Sultan Osman-i Evvel and Resadiye. The unfinished Ottoman submarines would be completed as the British submarines E-25 and $\mathrm{E}-26 .^{312}$

The Ottoman Navy did acquire a submarine during World War I when the French submarine Turquoise ran aground while being fired upon after surfacing in the Sea of Marmara. Built in 1907, the Turquoise was equipped with two $450 \mathrm{~mm}$ torpedo tubes and had a speed of seven knots submerged and eleven surface. It was a jinxed ship, plagued with electrical problems, and since it was French, no spare parts could be acquired. After capture, it was put to use as a propaganda tool but because of mechanical problems, it was laid up at Istanbul and used as a battery-charging station for German submarines working in conjunction with the Ottomans. The submarine's name was changed to Müstecip Onbasi in honor of the officer in charge of the shore batteries that fired upon the surfaced Turquoise and subsequently forced it aground. ${ }^{313}$

${ }^{312}$ Güleryüz, 160.

${ }^{313}$ Ibid., 161. 
Further navy plans envisioned by the German Admiral Souchon called for a submarine force of twelve craft and assorted surface combatants. This plan was contingent on a successful outcome of World War I and further plans envisioned a submarine force of thirty-six craft. ${ }^{314}$ The Ottoman government did request and receive submarine assistance from Germany. To expedite this request, Germany requested Austria to send submarines from Pola to Istanbul. But Austria feared war with Italy and turned down the request. Germany did send U-21, captained by Lieutenant Commander Otto Hersing. ${ }^{315}$ Additionally, two small UB I class boats were sent by rail to Pola, Austria, where they would be assembled by German engineers and arrived in April at Istanbul. ${ }^{316}$ The injection of submarines into the Gallipoli campaign altered the AngloFrench plans. Germany would make several classes of submarines available to the Ottomans: UC, mine laying craft of 190 tons, speed $6 \mathrm{KTS}$; UB, coastal patrol submarines of 500 tons, speed $10 \mathrm{KTS}$; and U-boats or oceangoing submarines of 850 tons, $16 \mathrm{KTS}$.

When Italy entered the war on the side of the Entente in August 1916, Ottoman military planners utilized submarines to ferry supplies to the Senussi in Libya. German naval planners objected to the use of submarines for delivering supplies but the German Foreign Office promoted the venture. The use of UC-II minelayers UC-20 and UC-73 as

${ }^{314} \mathrm{Ibid} ., 28$.

${ }^{315}$ Lowell Thomas, Raiders of the Deep (New York: Garden City Publishing Company, 1928), 55.

${ }^{316}$ Halpern, A Naval History of World War One, (Annapolis: Naval Institute Press, 1994), 69-70. 
transports lasted until the war's end in 1918 and allowed the Senussi to tie down both the British and Italians. Submarines supplied Senussi attacks into Egypt in 1916 prevented British General Allenby from advancing into Palestine until 1917.317

Submarine action in the Black Sea was not as successful as Ottoman Naval planners had envisioned. The small UB U-boats were underpowered for the swift currents of the Black Sea and did not have the steaming radius necessary for long-range patrols. The need for submarines in the Black Sea was to protect merchant shipping, upon which the Russian Navy preyed upon. Because there were few developed roads and even less rail lines, almost all Ottoman commodity traffic was by ship. Protection of merchant shipping in the Black Sea dictated use of German submarines to counter Russian warships hunting such vessels. Supplies of coal and oil had come from Russia prior to the war. Once war had started, replacement for such commodities had to come from Germany by rail or from conquered Romania. In both cases, cargo had to transit by sea at some point, making an excellent target. Table 23 lists Russian losses to German submarines.

The Russian losses to submarines were not great but caused Russian naval strategists to re-think offensive raids against Ottoman colliers. The possible threat to major Russian combatants from submarines dictated an aggressive anti-submarine program. The Russian anti-submarine program in itself was not successful. Only one German U-boat was sunk due to direct Russian action. However, four German 
TABLE 23

RUSSIAN LOSSES TO GERMAN SUBMARINES IN THE BLACK SEA

Name

UC-15

Zivucij

UB-7

Patagonia

UB-14

Apseron

U-38

Cementkrug

Rockliffe

Vpered

Florida

UB-33

Teoskepasti

\section{UB-45}

Tevere

Gioconda

\section{UB-42}

Petr Darsi

Carica

Sirakuzy
Tonnage

350

6011

1850

1086

NA

858

3283

2481

2666

3701

731

2891

1086
5 February 1916

\section{Date}

4 April 1916

15 September 1915

8 October 1915

8 June 1916

2 July 1916

8 July 1916

10 July 1916

31 August 1916

2 September 1916

3 September 1916

19 October 1916

22 November 1917

Russian losses to submarines: 13.

Source: René Greger, The Russian Fleet, 1914-1917 (London: Ian Allan Ltd., Shepperton, Surrey, 1972), 66. 
submarines were lost to mines.

Russian action against submarines did relieve pressure on the Ottoman colliers.

The shortage of coal in Istanbul hampered the war effort and affected civilian morale. Any relief afforded to the colliers had to be seen as positive. Submarine action in the Black Sea ceased once the Russian Revolution spread to the Russian Black Sea fleet. Russian naval action during the fall of 1917 had begun to wind down due to the political and economic situation. ${ }^{318}$ Also German submarines had been restricted in operations because the economy of the Ottoman Empire was nearly prostrate. Submarine warfare had proven a success in the Black Sea. Had the Ottoman Navy possessed adequate numbers at the beginning of the war, the Russian offensives against the colliers and the amphibious landing in the Caucasus and on the Romanian coast may not have been successful.

German officers also learned new submarine techniques from the Ottoman theater. Mines needed to be customized for submarines. Attempting to use ship-delivered mines had proven dangerous due to buoyancy difficulties. The use of multi-sub attacks caused the Russians to marshal the Black Sea fleet temporarily until suitable Russian seaplanes arrived to ferret out the U-boats. Delivery of supplies to the Senussi in Libya proved to be a legitimate role for submarines: a lesson not lost on a young German Lieutenant Karl Dörnitz of the Yavuz.

${ }^{318}$ David Woodward, The Russians at Sea (New York: Frederick Praeger, 1965), $180-183$. 
Ottoman military use of advanced technology of airplanes and submarines is evidence of the forward thinking of naval planners in Istanbul. The Ottomans did not possess the ability to fabricate such weapons but utilized what was provided by Germany. The planes and submarines may not have been the "wonder weapons" hoped for by the Ottomans, but the presence of such technology in the theater forced the Allies to re-think offensive action, and such gave the Ottomans time to adjust. 


\section{CHAPTER VI}

\section{MANNING AND SHIPPING}

The term "naval asset" encompasses ships, bases, personnel, and infrastructure to support fleet operations. Naval warships require huge support backup in order to function away from port and not all naval assets are clearly identifiable. To crew ships, a dynamic pool of trained personnel are required. Crew turnover due to retirements, death, end of contract, seashore rotation, and differences in war and peace manning levels keep manning levels in flux.. This pool can be reserve or active, but the situation which demands naval action rarely allows for normal training cycles. Personnel demands can be immediate and the inability to properly crew a ship can lead to disaster.

Ship-related industries, such as shipyards, steel fabrication, fueling centers, rail terminals, and commercial aquatic resources, all dictate the success or failure of a nation's naval base. Warships are maintenance driven, and without proper care, a warship becomes inoperative and it's life cycle can be reduced to one-fourth. Modern warships are constructed with steel and an indigenous steel industry frees a nation from importation difficulties. Coupled with adequate shipyard facilities, locally produced warships can become a catalyst for national economic activity. Remove either and a nation is open to extortion and economic stagnation from states that can produce warships. 
The Ottoman navy at the beginning of the twentieth century had a bloated billet or job allotment of 32,000. A naval officer rank was little more than an additional source of income. Unlike an army commission, where the holder was likely to be called upon to fight, the low opinion of the fighting ability of the navy and thus the small potential of personal harm made a naval commission a luxury. Demand for a military stripped with slight risk resulted in little turnover. With little turnover, the upper ranks became bloated with career officers of little worth. When the upper ranks became bloated, young officers became trapped, unable to rise through the ranks.

In 1907, the nominal strength of the Ottoman navy was six vice admirals, eleven rear admirals, 208 captains, 289 commanders, 228 lieutenants, 187 ensigns, and 30,000 sailors. The typical contract for enlisted members was twelve years. ${ }^{319}$ In addition, Pears recounts a discussion with a young Ottoman officer who had one chance of promotion: wife's connection with one of the Palace ladies. ${ }^{320}$

The British Admiral Sir Douglas Gamble became advisor to the Ottoman Minister of Marine on 18 September 1908. ${ }^{321}$ Admiral Gamble found the Ottoman navy had on the roles more than 5000 officers. At that time the country was in the pains of a revolution started by Fazil Niazi Bey in Macedonia. Revolutionary zeal in Istanbul was ignited by a shot from a $230 \mathrm{~mm}$ cannon aboard the Ottoman central battery ironclad

${ }^{319}$ Monroe, 144.

320 Pears, 222.

${ }^{32 !}$ Güleryüz, 14. 
Necm-i Sevket. ${ }^{322}$ The shot was a signal for the "Young Turks" to seize the government of Sultan Abdul Hamid II.

Between 1908 and 1911, the navy minister was changed nine times. Because each minister had a different view of the British/Ottoman relationship, Gamble's mission was difficult if not impossible. Gamble's instructions were to continue training to obtain orders for the English shipbuilding industry, and to protect British interests in the Ottoman Empire. Gamble started his tour as Naval Advisor by proposing that the average naval officer corps be reduced in size and rejuvenated by the promotion of younger, British-trained officers. The proposals proved to be impossible to implement fully. The stripped of a naval commission where promotion was dependent on the benevolence of influential contacts, was not to be relinquished voluntarily. A case in point was the stationary ship, Ihsaniye. Under normal peacetime manning, a crew of thirty-five was sufficient. Of the thirty-five, thirteen were officers who had never seen the ship but drew naval pay. In addition to the reluctance to reduce the officer corps, Gamble had to contend with political rivalries between the Ottoman Naval Ministers and the Ottoman Foreign Office. The Naval Ministry tended to favor British views while the Foreign Office was influenced by Germany. ${ }^{323}$

Gamble did have some success in reducing the officer corps, Ottoman naval personnel reported by Jane's All the World's Fighting Ships 1911 showed a reduction to

${ }^{322}$ Ibid, 13.

${ }^{323}$ Ibid., 14. 
6,000 active service members. ${ }^{324}$ On the surface, a reduction in force of 26,000 over a three-year period indicated extremely inflated personnel numbers.

On the surface, such reductions tend to be positive. Younger officers and enlisted men would be able to exercise a greater responsibility and thus would become more proficient at warfighting. However, the reduction to 6,000 active navy personnel left little more than a skeleton force manning the fleet. Using ship-specific complement figures from Ahmet Güleryüz's The Ottoman Steam Navy 1828-1923 and Robert Gardiner's Conway's All the World's Fighting Ships, 1906-1921 reveals that the reduction left the Ottoman fleet badly undermanned. Table 24 lists ships on the active navy list as of 1 January 1912 and the required complement for minimum peacetime manning. The numbers do not include staff personnel at fleet headquarters in Istanbul, divisional staff at the assorted bases, or include base personnel involved in navy controlled shore facilities such as maintenance, armories, schools, or shipyards. Personnel working on naval bases and naval facilities may be civilian or military. Early twentieth-century military-industrial complexes doubled as both working repair facilities and training schools and were staffed with active-duty personnel. Additionally, ship crews typically performed the bulk of shipyard repairs utilizing the infrastructure not available at typical naval bases. However, even if the reduced fleet were more efficient, the total number did not allow for quick expansion or replacement crews. Two examples are the Barbarossa Hayreddin and Turgud Reis. When the two ships were acquired, each required a wartime

${ }^{324}$ Fred T. Jane, All the World's Fighting Ships, 1911 (London: Sampson Low Marston, 1911; reprint, New York: Arco Publishing Company, 1969), 451. 
TABLE 24

OTTOMAN SHIP BILLET REQUIREMENTS

$\underline{\text { Ship }}$

Barbaros Hayreddin

Torgud Reis

Peyk-i Sevket

Berk-i Satvet

Mecidiye

Hamidiye (cruiser)

Gayret-i Vataniye

Berk Efsan

Peleng-i Derya

Drac

Nurulbahir

Iclaliye

Basra

Ertugrul

Yozgat

Taskopru

Istanbul

Sogutlu

Yadgar-i Millet

Mwavenet-i Milliye

Numune-i Hamiyet

Samsun

Tasoz

Sivrimisar

Demirnisar

Sultanhisar

Musul
Crew

$\underline{\text { Ship }}$

Crew

900

900

145

145

355

355

90

62

110

20

45

180

91

22

12

52

9

35

111

111

111

91

91

20

20

20

20
Kutahya

Zuhaf

Nevsehir

Tirimujgan

Hamidiye (gunboat)

Mesudiye

Asar-i Tevfik

Yarshisar

Hamidabad

Akhisar

Antalya

Tokat

Feth-i Bulend

Muin-i Zafer

Timsah

Izzeddin

Trabzon

Beyrut

Malatya

Kilid Bahir

SUBTOTAL

Motorboats 1-25: 6 each

TOTAL

6,458

20

82

52

110

20

665

350

91

20

43

20

20

150

200

17

35

67

47

47

82

$\underline{6.308}$

150

150

Source: Ahmet Güleryüz and Bernd Langensiepen, eds., trans. by James Cooper, The Ottoman Steam Navy 1828-1923 (Annapolis, MD: Naval Institute Press, 1996), 196. 
crew of 1100 . The crews had to be provided from the fleet by drawing a large proportion of the relatively trained ratings from active ships and many ships were reduced to skeleton crews. A similar problem occurred in the autumn of 1910, when the four Schichali-class destroyers were delivered. ${ }^{325}$ With the purchase of the Rio de Janeiro, raw recruits were conscripted from Ottoman maritime provinces. From this group, only 500 were physically qualified to enter into the Navy, not enough for a skeleton crew. The British Navy agreed to provide retired technical ratings and deck petty officers in order to acquire a working crew for the battleship. ${ }^{326}$

Admiral Gamble's reduction left in question manning for ships on order from foreign shipyards. Ottoman ships ordered as of 1 January 1912 required a peacetime complement of 1600 men. The manning-levels that Gamble instituted also do not mirror the Ottomans' traditional rivals, Russia or Greece. Greece did not decrease manning, and Russia increased it seventeen percent. ${ }^{327}$ The reduction in force enacted by Admiral Gamble jeopardized the manning of the Ottoman Navy, at the very time the Sultan's traditional enemies were expanding. The rationale for the reduction, weeding out overaged and non-productive naval service members, is understandable but questionable It is reasonable to expect Admiral Gamble to have known of Greek warship purchases and modernization and of Russian Black Sea expansion plans. It is inconceivable that

325Viscount Hythe, The Naval Annual 1911 (Portsmouth: J. Griffin \& Co., 1911), 53.

326Hough, The Great Dreadnought, 102.

327Jane, All The World's Fighting Ships, 332. 
Gamble could not have known of Italian-Greek imperialist aspirations for his 1910 naval expansion plan called for two battleships, three cruisers, and ten destroyers. ${ }^{328}$ The concern which prompted such a program originated in Athens, but yet, Gamble reduced the fleet to an anemic personnel level at the same time he requisitioned ships Istanbul could not crew.

The British Mission found all responsibility rested with the Minister of Marine, and senior Ottoman naval officers would not deal with any request nor state opinions for fear of negative repercussions. The organization and provisions of the fleet was based on the supposition that the ships would be in touch with Istanbul and therefore that daily ration papers and monthly pay lists could be taken to the Admiralty for corrections. When Williams ended his tour of duty in the spring of 1912, there was still no provision for providing a bread and meat ration at sea, although such a ration was issued daily in harbor. Ottoman crews at sea had to rely on biscuits, olives, and bread. ${ }^{329}$ The Ottoman Training Station was on the island of Halki but With the influx of raw recruits for the Reshadieh and Sultan Osman-i Evvel an additional training school was set up in the Sultan's palace..$^{330}$

The career of an enlisted person in the Ottoman navy mirrors the prevailing material situation of most early twentieth-century fleets. In general, the enlisted member would spend the bulk of his career on one ship. Cruises were usually less than a week,

${ }^{328}$ Güleryüz, 14.

${ }^{329}$ Hythe, The Naval Annual 1911, 53.

330Hough, The Great Dreadnought, 102. 
three days being the average. Accommodations were sparse and in most cases the crew member slept in the workplace. In larger ships, sharing racks, called "hot bunking," was normal. Dining facilities on average ships were outside in good weather, in passageways or work spaces in inclement periods. To average sailors, the ship was home. Spartan by late twentieth-century standards, the creature comforts found on board the Sultan's ships were nevertheless considerably higher than found in ground units. That improved living standards and absence of long-term separations resulted in few desertions compared to those within ground forces. Typical enlistment were for five years active, seven reserve. However, the Italian and Balkan Wars had disrupted the cycle, by extending contracts. This resulted in some mutinies from restlessness on ships anchored at Istanbul. ${ }^{331}$ The C.U.P. achieved power in 1909, and at once friction with British naval advisors began. Ahmet Güleryüz writes that the underlining issue was foreign involvement in fleet expansion and German-inspired Foreign Office meddling. ${ }^{332}$ But diplomatic intrigue could not hide the fact that Gamble's reforms did not bring about Ottoman naval professionalism and may have intentionally hampered Ottoman national security. The C.U.P. Naval Minister Albey Mehmet Muktar refused to work with Gamble and refused to cooperate in any project because of the appearance of fraud. The two preceding Naval Ministers, Ali Pasha and Tümamiral Halil Pasha, both attempted to enact Gamble's programs and found the "wheeling and dealing," typical of Abdul 
Hamid's regime and seemingly encouraged by English shipyards, unacceptable to the reform-minded Young Turks.

At the request of Tumadmiral Halil Pasha, Admiral H.P. Williams, Gamble's replacement in April 1910, instituted Ottoman officer training in Britain. Between 1910 and 1912 approximately forty Ottoman officers attended British naval schools and twelve at private shipyards. However, British concerns for English naval secrets led London to suspend foreign-officer training on British ships and in the yards. The British Foreign Officer Minister Sir Edward Grey agreed to pull all Ottoman officers, regardless of prior agreements with Istanbul. Admiral Limpus, Williams' successor, requested that a number of Ottoman officers be allowed aboard the H.M.S. Orion or Monarch, vessels similar to the two dreadnoughts ordered from British yards. The British Admiralty, following new instructions, refused to do more than allow the Ottoman officers to attend gunnery school on shore. ${ }^{333}$ A group of Ottoman officers did attend the British gunnery school at Whale Island and were provided instruction using twin twelve-inch dummy guns in turrets similar to Sultan Osman-i Evvel. ${ }^{334}$

With no outlet for training in Britain and assignment to British warships curtailed, Admiral Limpus improvised by creating mockups of battle stations on the Ottoman warship Messudiyeh. The British Lieutenant Frank Elliott instructed Ottoman naval gunnery crews in firing discipline and the sighting of targets. Elliott created a five-week

${ }^{333}$ Halpern, The Mediterranean Naval Situation, 322-323.

${ }^{334}$ Hough, The Great Dreadnought, 103. 
school that provided the first basics of naval gunfire training and tailored the training to mimic the action required to load, aim, and fire the weapons found upon the Sultan Osman-i Evvel and Reshadieh. ${ }^{335}$ However, the training was limited and resources were scarce. This resulted in little more than superficial knowledge and could not provide the level of competence needed to fully utilize weapon systems found upon the newly purchased destroyers or ordered battleships.

\section{Marines}

Marines are the premier fighting force that performs roles bridging armed naval detachments and army units. Traditional functions assigned to marines are shipboard security, pier sentry, and base security. Robert Gardiner, editor of Conway's All The World's Fighting Ships, reported the Ottoman navy possessed a marine force of 9,000 troops in 1906 and Fred T. Jane, in All The World's Fighting Ships from 1907 through 1919, lists a force of 9,000 in 1907. But by 1918 a force of less than 4,000 were reported. There is no documentation as to the disposition of marine forces in Gamble's reduction in force program. But Ottoman marines reportedly mutinied in December 1906 over discharge orders and pay and fearing a repeat, the marine force may have been reduced by political orders. ${ }^{336}$ Photographs of Ottoman marines in action and in parade can be found in Holland Thompson's The World War, and the Times' History of the War, Vol.

${ }^{335} \mathrm{Ibid} ., 103-105$.

336The New York Times, 17 December 1906. 
III. $^{337}$

A plausible explanation for the reduction of the Ottoman marine force can be found in the Black Sea. Enver Pasha, the Ottoman War Minister and acting Navy Minister in the absence of Djemal Pasha, ordered three transports, Bahri Ahmir, Midhat Pascha and Bezmi Alem, to Trebizond. The transports were fully loaded with weapons, provisions, and reinforcements. A Russian squadron in search of Yuvaz and Berk-i Satvey intercepted the unescorted transports and sank all three on 6 November $1914 .{ }^{338}$ The exact number of troops each ship carried is not known. However, using the premise that combat loading for short duration could exceed 6,000 troops on the Ottoman transport Izmir, the author speculates the unescorted transports sinking could have resulted in a loss of 10,000 troops. The 11 November 1914 Louisville Times reported a Russian Black Sea source claim to have sunk three transports loaded with ammunition, guns, airplanes, cargo and troops. In addition the fully loaded Ottoman transport Beritel was sunk on 13 December 1914.339 The sinking of four combat loaded transports and the loss of experienced combat troops would explain the reduction in the marine forces.

Marines are sea-based soldiers, and it would be expected such troops would be first in any landing at Rize and the three transports sunk, Bahriye Amer, Bezm-i Alem and

${ }^{33} 7$ Holland Thompson, ed., The World War, Vol. II (New York: The Grolier Society, 1921), 337; and The Times, History of the War, Vol. III (London: The Times, 1915), 64.

338René Greger, The Russian Fleet, 1914-1917 (London: Ian Allan Ltd., Shepperton, Surry, 1972), 46.

${ }^{339} \mathrm{Ibid} ., 68$. 
Mithat Pasha, were on the first run and would have been carrying sea-based troops, or marines. Unlike American sealift where the United States Navy controls all shipping, Ottoman troop transports were under the control of the army, not the navy. Souchon did not want convoy duties but he relented when confronted by Enver. ${ }^{340}$ However, the army did not keep to any reliable time schedule, resulting in underutilization of Ottoman ships. During the Balkan War, Enver controlled the troop transports and failed to keep naval commanders informed, resulting in missed opportunities and communication difficulties. Unlike the Balkan Wars, when the Sea of Marmara was secured, Russian Black Sea forces pressed every opportunity and miscommunication would prove to be disastrous.

\section{Merchant Shipping}

Ottoman waterborne break-bulk shipping had never been large. Large ships were not profitable outside of large Ottoman cities because the Ottoman Empire had few developed roads and even less rail development, transportation was via small, locally produced watercraft. Small shallow draft craft served the commercial needs of the Empire very well during peace but during wartime additional sealift is needed. The Ottoman mercantile marine or civilian vessels capable of being requisitioned for military use numbered 143 steamers of 69,333 tons net and 900 sailing craft of 180,000 tons net. $^{341}$ Shipping capabilities had expanded little from 1907, when the mercantile navy listed 107 steamers and 916 sailing vessels. In 1907, forty percent of the Empire's

${ }^{340}$ Güleryüz, 45.

${ }^{341}$ Jane, All The World's Fighting Ships, 1914, 409. 
exports and imports were carried in English ships. Greek ships accounted for ten percent. $^{342}$

During World War I, The Russian Black Sea fleet targeted Ottoman merchant ships with some success. Exact tonnage loss is difficult to ascertain, for many Ottoman colliers thought to be sunk were refloated after "sinking." The significance of civilian colliers cannot be underestimated. The main Ottoman coal port was Zonguldak, roughly 150 miles from the Bosporus Strait on the Black Sea and this open sea run to the safety of the Bosporus Strait made slow Ottoman colliers easy prey for the fast oil-burning destroyer the Russians had on hand. Protection of merchant shipping was at first a low priority to both Souchon and Enver but protection became top priority once the resources Russia provided prior to the war, such as coal, oil, and wheat, began to be imported from neutral Romania. Protection of merchant shipping would see German submarines, normally offensive in action, become shepherds to colliers.

The Russia Black Sea fleet, though numerically superior to the Ottoman fleet, was in fact inferior where the Yavus was involved. Except when the Russians had numerically overwhelming firepower, Russian Admiral Ebergard, Commander of the Black Sea Fleet, concentrated on commercial interdiction. The Russians blockaded the coaling port of Zonguldak with both ships and mines and when intelligence confirmed Trebizond as an amphibious landing area for Ottoman troops, that region was mined and blockaded. The results of the relentless pursuit of Ottoman colliers and transports is 
found in Table $25 .^{343}$

The commerce war was not one-sided and the Ottoman's attacked Russian auxiliary ships and merchants whenever the possibility arose. The number of ships sunk both sides peaked between September 1915 and September 1916. Russian losses accelerated once Enver's Caucasus fiasco was over and the naval assault upon the Dardanelles ceased. Ottoman fleet units, with help from transplanted German U-boats, made Black Sea sorties hazardous for both Russian military and civilian craft. However, Admiral Ebergard marshaled the Russian fleet, resulting in diminishing success for Ottoman surface ships and German U-boats.

Russian success at merchant interdiction peaked in the spring of 1915. Much of the Russian success was due to Enver's haphazard use of transports in the Caucasus campaign. Russian success against Ottoman waterborne break-bulk and troop transports occurred only when scheduling conflicts left the craft unprotected. Once deployment of troops no longer demanded waterborne lift, thus releasing Ottoman naval forces to pursue Russian shipping, Ottoman losses decreased and Russian losses increased. However, Ottoman losses could not be replaced and when the pace of wartime demands quickened, shortages of commodities carried upon water occurred. There was never a shortage of coal at Zonguldak, just a lack of colliers. The assignment of convoys for both transports and colliers would have lessened the losses. Curtailing the Caucasus campaign with its overextended communication and supply lines would have been expedient. Shortening 
TABLE 25

OTTOMAN LOSSES TO RUSSIAN BLACK SEA MINES

Year

1914

1915

1916

1917 $\underline{\text { Ships Sunk }}$

7

44

23

12

86

\section{Gross Tons}

23,230

52,567

26,989

1.676

104,462

Source: René Greger, The Russian Fleet, 1914-1917 (London: Ian Allan Ltd., 1972), 6769.

the defensive distance would have forced the Russians into extending communication and logistic corridors while at the same time saving the Ottoman X Army Corps from decimation.

Carl von Clausewitz, a noted military planner wrote: "a prince or general can best demonstrate his genius by managing a campaign exactly to suit his objectives and his resources, doing neither too much or too little. ${ }^{11344}$ Enver had an objective in the Caucasus campaign, stopping four Russian armies pouring across the frontier, but deploying ships and troops in such a haphazard manner was counterproductive. Results indicated Enver failed to plan, organize or think through the expedition. Compounding the situation, Enver had convinced Ahmed Djemal Pasha, the Ottoman Minister of Marine, to command Ottoman forces in Syria; and Tschurukasla Mahmud, the assistant

${ }^{344} \mathrm{Carl}$ von Clausewitz, On War, trans. and ed. by M. Howard and P. Paret (Princeton: rinceton University Press, 1984), 177. 
Minister of Marine, resigned along with other ministers over the unprovoked attack upon Sebastopol. The removal of experienced naval planners left merchant captains and naval commanders out of the information loop. The vacuum created a communication void for Enver, resulting in a lack of coordinated action and a navy without insightful leadership. Lack of communication cost the Ottomans troops and shipping, which were both irreplaceable. 


\section{CHAPTER VII \\ THE DARDANELLES}

Historical accounts of the battle for the Dardanelles stress the failure of the Entente ground forces in securing the Gallipoli Peninsula and thus the thwarted march into Istanbul. However, the ground campaign was caused by a textbook, naval defensive mine operation orchestrated by the Ottoman navy and conducted by the German Admiral Guido von Usedom. Usedom and the Ottomans were aided by the arrogance of AngloFrench commanders who arrogantly planned for Ottoman capitulation in a timely manner. Also assisting the Ottomans was the decision by Russia not to actively attack the Bosporus Straits from the Black Sea and the massive Russian mine barrage outside of the Bosporus Strait. The combination of Entente arrogance, Russian abstention, along with mine apprehension, all coupled with Ottoman immovability, created the Entente defeat in the Dardanelles. The victory rested squarely with mines, how the Ottomans deployed such weapons, and the Anglo-French reaction.

Two types of mines were available in 1914: observation and contact mines. Observation mines are electrically activated and are utilized for offensive purposes. The mine must be ignited by an observer. The positive aspects of such weapons are that areas seeded are still available for passage and not off limits to Allied ships. The negative aspects rest on the observer and electrical current. Observation mines need constant monitoring and electrical power. Remove either, and the mine becomes useless. Contact 
mines are designed to explode when struck by a ship. The mine usually is kept at a certain depth below the surface. The Ottomans' inventory consisted only of contact mines.

Mine ignition is generally effected by electricity via internal batteries, with the circuit being closed by shock of contact or established by electrochemical means. In some mines, ignition is effected by purely mechanical means, or percussion. In order to prevent accidental explosions prior to seeding, safety breaks are placed between contact points (horns), and detonators. Safety breaks are made from sugar and water. The hardened sugar prevents premature detonations, and the sugar dissolves shortly when exposed to water.

Contact mines are used in all cases where control from shore stations cannot be secured, such as war zones or approaches to fortifications for defensive purposes. The mines may be anchored to create a minefield or line, or left free floating. Free floating contact mines are best used when current will drift the weapon down upon enemy an anchorage or into established sea lanes. Free floating contact mines may ride upon the surface or, with the use of ballast weight, drift beneath the waves.

The explosive utilized in Ottoman mines was gun-cotton soaked in paraffin. The gun-cotton paraffin explosive would explode even when wet and extended the operational life of the mine. Additionally, gun-cotton soaked paraffin was safer to maintain and extended the shelf life of the mine. The weight of the explosive found in Ottoman mines is unknown. However, the average weight of pre-World War I mines, which comprised 
the bulk of the Ottoman inventory, was 130 pounds. ${ }^{345}$

The amount of explosive carried by a mine is limited by two conditions: the mine must not destroy adjacent mines or bring them to explosion; and the distance between mines must not exceed a certain maximum if the minefield is to be effective. Under ordinary seeding, distance between mines in rows is 200 to 300 feet. Russian minelaying utilized the "throw and go" seeding method, where mines are dropped without specific and at times adequate spacing. The "throw and go" method is quick but requires considerably more mines than planned fields. Ottoman minefields were laid in a timely, precise manner. All the minefields in the Dardanelles, with the exception of the last, had been seeded before the Anglo-French forces arrived in force. Table 26 lists the Ottoman minefields as of 8 March 1915. The exact layout of the mine lines is found in Appendix 8.

The coordinator of the Ottoman coastal defense was the German Admiral Guido von Usedom. Usedom would keep the German moniker "Inspector General of Coastal Fortifications and Minefields" while in service for the Sultan and was an expert on coastal and harbor defenses. ${ }^{346}$ Preceding Usedom was retired German Vice Admiral Wilhelm Schack, who arrived in May 1914 with howitzers from Krupp. Usedom arrived in theater on 30 August 1914 and set up headquarters at Canakkale. ${ }^{347}$ In order to protect mining operations, Usedom ordered all Entente officers out of the Dardanelles and began

${ }^{345}$ Havgaard, 442-443.

${ }^{366}$ Halpern, A Naval History of World War One, 56.

${ }^{347}$ Lumby, 428. 
TABLE 26

\section{OTTOMAN MINEFIELDS AS OF 8 MARCH 1915}

\section{Field Number}

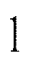

2

3

4

5

6

7

8

9

10

11 $\underline{\text { Total Mines }}$

63

29

28

39

47

38

50

16

48

29

20

\section{Date Seeded}

February 26, 1915

February 26, 1915

November 14, 1914 - February 19, 1915

November 14, 1914 - February 15, 1915

November 14, 1914 - February 15, 1915

November 14, 1914 - February 15, 1915

November 14, 1914 - February 15, 1915

November 14, 1914 - February 19, 1915

November 14, 1914 - February 19, 1915

November 14, 1914 - February 19, 1915

March 8, 1915

Source: James A. Meacham, "Four Mining Campaigns: An Historical Analysis of the Decisions of the Commanders," Naval College Review, Vol. XIX, No. 10 (June 1967), 77-83.

to deploy mine layers. However, Usedom did not close the straits. Instead, he opted to restrict the channel so that closure could be achieved quickly.

Admiral Usedom had doubts as to the survivability of the straits. Defensive preparations had not proceeded far enough to secure the waterway by the commencement of hostilities. Usedom believed that the straits could be forced by the Anglo-French forces assembled in theater, and he voiced such reservations to Admiral Souchon. ${ }^{348}$ What few defensive options open to Usedom were very limited; mine inventory consisted of English, Italian, Bulgarian, Greek and Russian, many having been left over 
from the Balkan wars; shore gun batteries had not been trained and were clearly open for visual attack; visual defenses had been acceptable in the nineteenth century, but concealment was necessary for survival in 1914. Usedom gambled that if the Entente could be forced into a close-quarter or "hugger-mugger" fight, good defensive measures could prevail.

Usedom did not fabricate mines in theater but instead created an indigenous munitions infrastructure to recondition deteriorated mine variations at Zeytin Burnu. To protect the mine fields from being cleared, a series of earthen emplacements were erected and left open to be seen, forcing a would-be enemy to destroy both manned and unmanned outposts. Miles of barbed wire and entrenchments had created a maze of defensive breastwork in order to concentrate fields of fire in the event of a forced amphibious landing. The ground campaign was commanded by Djevad Pasha and General Liman von Sanders.

In the event the Anglo-French forces penetrated the minefields, Usedom had placed a three-barrel, eighteen-inch torpedo battery at Kilid Bahr. The reload time for this battery was twenty minutes, creating a problem if more than one three-bank were fired. To compensate, the minelayer Bulair was loaded with floating mines, some compliment of the Russians, to release into the channel current in order to buy time for reloading. ${ }^{349}$ Finally, the Yavuz, Torgud Reis, and Barbaros Hayeddin stood ready to 
provide a last-ditch stand. ${ }^{350}$

Admiral Usedom's greatest achievement in assisting in the defense of the Dardanelles was training. The Germans did not have enough personnel in theater to achieve all objectives without assistance. Usedom trained the Ottomans on coastal protection and layered defense. The shared knowledge of Usedom and the Ottoman servicemen's grit created an unexpected reception for the Entente.

Confronting Admiral Usedom would be the Anglo-French naval forces commanded by British VADM Sackville Hamilton Carden, Commander Naval Forces in the Eastern Mediterranean. Carden's plans for the Dardanelles had three phases: silence the outer fortifications to the straits; silence the intermediate forts; force the straits to the Sea of Marmara. Carden anticipated success by utilizing the superior Allied naval forces, and the need to seize the high ground on the Gallipoli Peninsula was deemed unnecessary. ${ }^{351}$

The Allied campaign to force the Dardanelles was based upon the premise that the Ottoman Empire could be knocked out of the war quickly. With Germany's weaker ally out of the fight, Russia could be armed and a quick end to the Central Powers realized. England did possess naval forces adequate to subdue the fixed fortifications protecting the straits. England also had available flag officers with intimate knowledge of the capabilities and readiness of Ottoman defenses, because of tours of duty as naval advisors

${ }^{350}$ Van der Vat, 194.

${ }^{33} 1$ Paul G. Halpern, ed. The Keyes Papers, Vol. I (London: William Clowes \& Sons, 1972), 82-83. 
to the Ottoman Minister of Marine. In theory, the thrust up the Dardanelles to Istanbul could be accomplished with little expense.

With tensions rising, Usedom, on 6 September 1914, moved the ironclad Mesudiye to Nara in order to create a floating battery. On 29 September the British stopped the Ottoman gunboat Akhisar just outside the Dardanelles. The Akhisar was within the territorial waters of the Ottoman Empire. Britain was not at war with the Ottomans, and the English ship was in violation of Ottoman sovereignty. The English informed the Akhisar that all Ottoman warships and enemy merchants were blockaded. The intransigence of the English and the obvious possibility the straits might be rushed compelled Usedom to close temporarily the water course on 30 September. ${ }^{352}$ Usedom's fears of a surprise rush upon the straits had merit. On 1 November 1914 the destroyers H.M.S. Wolverine and H.M.S. Scorpion entered the Gulf of Izmit and sank the survey vessel Beyrut off Urla and the steamer Kinaliada. Britain was still "officially" at peace with the Ottoman Empire. But British actions indicated a plan to provoke Istanbul into declaring war. When the Ottomans refused, England and France initiated a declaration on 5 November, 1914.353

The British had deployed the submarines $B 9, B 10$, and $B 11$ at Tenedos by November 1914 in order to assist in the blockade of the Ottoman coast. On 13 December 1914 the British submarine B11, commanded by Commander Hochrook, RN, entered the

352Alan Moorehead, Gallipoli (New York: Harper and Brothers, 1956), 29. ${ }^{353}$ Güleryüz, 30. 
straits, transited five mine barrages, and sank the ironclad Mesudiye. Between November 1914 and February 1915, ten rows of mines and an antisubmarine net were put into place. The navigational aids were removed or rendered inoperative, and notices were promulgated that the straits were closed completely. ${ }^{354}$

In January 1915 Russian Supreme Commander, Grand Duke Nicholai Nikolayevich asked the British Liaison Officer for some sort of diversionary action to relieve pressure on the embattled Eastern Front. Mr. Winston Churchill, First Lord of the Admiralty, presented the idea of making a naval demonstration in the Dardanelles region. ${ }^{355}$ Churchill's conviction was expressed in the statement: "Through the Narrows of the Dardanelles and across the ridges of the Gallipoli Peninsula lie some of the shortest paths to a triumphant peace. ${ }^{1356}$ Admiral Fisher, First Sea Lord, vigorously objected to the plan to lay siege to the Dardanelles. Admiral Fisher's experience in the eastern Mediterranean convinced him that forcing the Dardanelles was an mistake. Fisher's objections were well known to the British War Council but the authorization to proceed was agreed upon on 28 January 1915. He recommended an defensive agreement with Istanbul prior to the war on the premise of having reliable access to Russia. Fisher, creator of the "dreadnought" and architect of the British Navy, intended to resign over the decision, but Lord Kitchner, British Secretary of State for War, convinced Fisher to stay.

${ }^{354}$ Henry Morgenthau, Secrets of the Bosporus (London: Hutchinson, 1918), 6869.

${ }^{335}$ Cassar, 95.

${ }^{36}$ Holland Thompson, ed., The World War, Vol. I (New York: The Educational Book Company, 1921), 340-341. 
London became occupied with the attractive political possibilities of the venture but the British failed to inform themselves of the actual existing resources available. The operation was launched without an adequate supply of troops, ammunition, or planning. The few troops available--Australian, New Zealand, and Indian--had not worked together or participated in combat work-ups prior to the landings on 25 April 1916. Assisting the English in the Dardanelles campaign were the French Navy under Rear-Admiral Guépratte. Guépratte's force consisted of older warships of questionable worth, which indicated Paris placed little emphasis on the Ottoman theater. In order to facilitate the attack, an informal agreement with Greek Prime Minister Venizelos gave the Entente use of the Greek island of Lemnos along with harbor accommodations at Mudros. Greece remained "neutral" during this period in name only. 357

The ground campaign was orchestrated by the English General Sir Ian Hamilton and the French General d'Amade. Hamilton had not worked with the troops or officers he commanded, delayed the movement of troops to staging areas when inspection of transports revealed that no combat cargo loading had taken place. The pell-mell approach to cargo was indicative of the entire operation. The lack of ground troops, necessary for the total destruction of fixed fortifications, forced the Anglo-French commanders to choose between delaying the operations in order to have the troops available, or forging ahead utilizing just naval gunfire. Carden chose to proceed without follow-on ground troops. 
The Anglo-French naval bombardment of the entrance to the straits commenced on 19 February 1915, and at that time British mine sweepers conducted exploratory sweeps in the Dardanelles and found no mines existed to seaward of Kephez Bay. ${ }^{358}$ The mine sweepers, manned by civilians and actually converted fishing trawlers, began to sweep the channel in earnest on 1 March 1915.359 The straits at Kephez Bay are less than 5000 yards wide. Usedom had erected defenses at Kephez Bay consisting of light mobile guns, powerful carbon arch search lights, and miles of telegraph wire. Additionally, Usedom brought the fledgling Ottoman naval and army air assists into the fray, preventing the Allies from achieving air superiority.

British forces landed on Lemnos on 25 February 1915 and began to prepare the island to support the Dardanelles operation. The relative ease of securing the island did not equate to the Gallipoli Peninsula because Usedom was concerned with the Straits, not the Greek islands outside the channel. Spurred on by the ease of the Royal Marines' success with the Dardanelles forts, Greece offered to aid in the capture of Gallipoli and Istanbul. On 1 March, Athens offered to cooperate in exchange for Smyrna and a substantial portion of Anatolia. Athens desired to acquire Istanbul or at least a neutralization of the city. The regional proximity of Greece proper and the large Greek resident population in Istanbul would ensure Athens' influence in regional decisions

${ }^{358}$ E. Keble Chatterton, Dardanelles Dilemma (London: Rich and Cowan, 1935), 90.

${ }^{359}$ Sir Roger Keyes, Naval Memories, Vol. 1 (New York: Dutton, 1934), 203. 
regardless of Russian desires. ${ }^{360}$ London gave no official approval, and Greece remained "neutral." However, on 3 March and again on 5 March, the Greek Royal Crown Council in Athens rejected any open involvement in the war. Venizelos resigned on 6 March, and active Greek support of Entente objectives was curtailed.

The Porte also faced the problem of Russian action in the Black Sea. The Russian Supreme War Council ordered on 19 February 1915 that the Russian Black Sea fleet prepare to transport 37,000 men of the V Caucasian Corps, based in Batum, to the Bosporus. The support of the Russian troops was based upon a successful breaching of the Dardanelles, and landing was anticipated in the first week of March, assuming the Ottomans capitulated. ${ }^{361}$

In order to prevent Ottoman warship action in the Black Sea, Russian ships had seeded the Bosporus Straits with 847 mines during November and December $1914 .{ }^{362}$ Because the area of seeding was outside of Russian control, protecting the fields and maintaining the integrity were impossible. Also, the current in the Bosporus Straits is a constant five knots, flowing from the Black to the Aegean Sea. The combination of fiveknot current and the Russian "throw and go" mine laying techniques resulted in a haphazard field and Usedom being able to harvest Russian mines for use in the Dardanelles. Additionally, Russia utilized floating mines called "little fishes." These mines floated down the channel and could pass through the Sea of Marmara, down the

${ }^{360}$ Cassar, 95.

${ }^{361}$ Greger, 48.

${ }^{362} \mathrm{Ibid} ., 70$. 
Dardanelles, and become a menace to the Anglo-French fleet or be harvested by the Ottomans. ${ }^{363}$

On 5 March 1915 HMS Queen Elizabeth, utilizing aircraft for spotting, attempted to fire across the Gallipoli Peninsula in order to silence the shore batteries. ${ }^{364}$ The English also utilized a method of "listing" wherein the ship was ballast on one side in order to increase the angle of the guns. Large caliber British naval guns had only a $15^{\circ}$ $25^{\circ}$ elevation range, which was good for ship-to-ship long range duels but inadequate for deflation fire. The efforts failed, and on 7 March the French tried to force the straits at Kephez, only to be repulsed.

The Ottoman minelayer Nousret seeded a minefield parallel to the channel at Eren-Keni Bay on 7 March. ${ }^{365}$ The Nousret laid only twenty mines, though the ship was capable of carrying forty. The on-hand mine inventory of the Ottomans had been very limited, and on 2 March the Ottoman gunboat Intibah transported the last mines of the arsenal in Istanbul. ${ }^{366}$ Any additional mines would have to be transported from Germany, or harvested from Russian fields. The Nousret-laid minefield was about 3000 yards long and roughly seven miles from Kephez. The mines were moored about fifteen feet below the surface. The depth setting was to target deep draft capital ships. ${ }^{367}$

${ }^{363}$ Van der Vat, 213.

${ }^{364}$ Ibid., 206.

${ }^{365}$ Chatterton, $120-121$.

${ }^{366}$ Güleryüz, 30.

${ }^{367}$ Keyes, Vol. I, 230-231. 
On 11 March the Anglo-French forces attempted to sweep the straits to seaward. The premise was that any mine cut loose from mooring cables would either be located and neutralized or swept to sea by the east-west current. Confronting the current was a major factor in the ineffectiveness of prior sweeping efforts. The British Commander, Roger Keyes, himself rode in the minesweepers during the attempt. ${ }^{368}$ A number of mines were swept, and one sweeper struck a mine and was destroyed. During the operation, several of the sweepers and escorting destroyers were mauled by the shore batteries. The sweep failed to clear the channel.

Carden and Keyes pushed ahead to force a channel. On 12 March the English augmented the civilians on the minesweepers with active-duty sailors. The mission would be to force the fields regardless of the losses. On the night of 13 March the downstream sweep was again attempted. The Ottoman defenses once more beat back the sweepers, allowing only a single, two-ship moored sweep to succeed. ${ }^{369}$

On 13 March the cruiser HMS Amethyst was severely damaged by indirect gun fire from fixed and mobile howitzers. The plunging fire could not sink an armored ship but could destroy command and control stations. With no command and control, communication breaks down, causing indecision. With this, the Allies began to contemplate injection of land forces to silence the guns in order to allow an adequate

${ }^{368}$ Archibald Steward and Charles J.E. Peshall, Immortal Gamble (London: Black and Co., 1917), 38.

${ }^{36}$ James A. Meacham, "Four Mining Campaigns: An Historical Analysis of the Decisions of the Commanders," Naval War College Review, Vol. XIX, No. 10 (June 1967): 79 . 
sweep of the channel. From 13 to 17 March sweepers conducted check sweeping of the area to seaward of the Kephez fields. This effort was undertaken to ensure the force of battleships and cruisers had a clear channel for a planned daylight effort to force the straits on 18 March. A daylight assault was planned in order to allow naval gunfire spotting upon Ottoman fixed and mobile gun emplacements. Additionally, a daylight sortie allowed the use of aircraft for gunfire spotting and mine reconnoitering. ${ }^{370}$

Because of illness, the Anglo-French commander, Admiral Carden, was replaced by the Rear Admiral Michael de Robeck on 16 March 1915. Admiral Robeck had taken part in the planning of the daylight assault and indicated no desire to alter the plan.

British airplanes had been tested for minesweeping duties and had the ability to detect mines up to a depth of eighteen feet. Reports from aviators indicated no mines seaward of the Kephez fields, even though the Nousret had laid twenty on 7 March. The of the mines laid by the Nousret had escaped detection. The plan of attack was as follows, as taken from the planning memorandum of Carden's: "The general idea is to silence the defenses of the narrows and of the mine field simultaneously, so as to enable the sweepers to clear a passage through the Kephez mine field; if this is successful the attack will be at once continued on the remaining defenses until the fleet has passed through the Dardanelles." ${ }^{1371}$ The Anglo-French battleships commenced bombardment at 1100 hours on 18 March with the mine sweepers going into action two hours later. ${ }^{372}$ At 1345 hours,

${ }^{370} \mathrm{Ibid} ., 80$.

${ }^{31}$ Keyes, Vol. I, 226.

${ }^{372}$ Meacham, 81. 
the French battleship Bouvet struck a mine while maneuvering around the Nousret's mine line. The Bouvet blew up, capsized and sank within two minutes. Out of her complement of 709, only 71 were saved. ${ }^{373}$ At 1611 hours, HMS Inflexible also struck a mine of the Nousret"s line. The ship did not sink, however, and was beached at Tenedos and eventually repaired. At 1614 hours, HMS Irresistible hit a mine. Finally, at 1900 hours, HMS Ocean became the last victim of Nousret's minefield. Both the Irresistible and the Ocean sank during the night of 18 March. The two ships' crews were removed by destroyers working under incoming fire from Ottoman gun emplacements. ${ }^{374}$

The Anglo-French commanders conferred upon the Queen Elizabeth and concluded, "...the battleships could not force the straits until the mine field had been cleared--the mine field could not be cleared until the concealed guns which defended them could be destroyed, and they could not be destroyed until the peninsula [Gallipoli] was in our hands, hence we shall have to seize it with the Army."1375 With this recommendation, the Dardanelles operation evolved into a ground campaign regulating the Anglo-French naval units to a secondary role. The removal of aquatic forces, in which the Entente enjoyed supremacy, and their replacement by ground forces, in which the Ottomans enjoyed superiority, would result in defeat and ultimately withdrawal of Entente forces in January 1916.

${ }^{373}$ Claude Ferrere, Histoire de la Marine Française (Paris: Flammarion, 1956), 374.

${ }^{374}$ Meacham, 82.

${ }^{373}$ Baron Rosslyn E.W. Wester-Wemyss, The Navy in the Dardanelles Campaign (London: Hodder and Stoughton, 1924), 41-42. 
The Anglo-French forces failed to force the Dardanelles because the British were afraid to force the minefields. The British believed it was necessary to sweep a guaranteed safe passage prior to the passage of heavy warships. British Admiral Keyes in his memoirs declares, "...there was never any question of taking battleships through unswept mine fields. ${ }^{1376}$

Reliable intelligence on the mines was grossly neglected. The British had the expertise of admirals Limpus and Gamble to draw upon but instead seemed to have relied upon exaggerated mine figures from Greek sources. Admiral Kerr, British advisor to the Greek Royal Navy, reported from Athens that the Dardanelles were protected by 17 rows of mines at the Kephez-Chanak Narrows. ${ }^{377}$ Additionally, British Captain Kennedy, reporting from HMS Indomitable to Rear Admiral Troubridge, Commander of the British First Cruiser Squadron, Mediterranean, claimed to have the plans for the Ottoman minefields in mid-August $1914 .^{378}$ Good intelligence in mine defense could have calculated the available mines and the optimum hazard those fields represented.

The total number of mines laid by the Ottomans at the Kephez barrier was 352 . Of the 352, fewer than 150 had been laid after 1 January $1915 .{ }^{379}$ The total number of mine lines was eleven. To successfully mine the narrows at Kephez, it would take

${ }^{376}$ Keyes, Vol. I, 246.

${ }^{37}$ Mark E.F. Kerr, The Navy in My Time (London: Rich and Cowan, 1933), $182-$ 183.

${ }^{378}$ Captain Kennedy to Rear Admiral Troubridge, 18 August 1914, Lumbry, 442.

${ }^{379}$ Hans Kannengiesser, The Campaign in Gallipoli (London: Hutchinson, 1928), 56. 
approximately 26 mines in line, spaced at about 100 yards. ${ }^{380}$ Good intelligence would have indicated that clearing a channel directly ahead of capital ships would suffice for transit. Yet, on 18 March, when such an endeavor was planned, Admiral Robeck hesitated when confronted with the Nousret's mine field, a mine line outside of the transit route. When severe losses to mines had occurred, there was no longer any thought of challenging the mines anywhere until the guns had been silenced so that the sweeper could clear the threat. ${ }^{381}$

The defense of the Dardanelles and the predicament of the Anglo-French forces altered Russia's strategy. Before the Dardanelles campaign, Russian naval forces were very active, mining the Bosporus Strait, shelling the coaling facility at Zonguldak, and wreaking havoc on Ottoman shipping. But on 17 February 1915 the Russian Supreme War Council forbade the Black Sea fleet from leaving Sevastopol. ${ }^{382}$ The reasons are not given but the absence of a tangible threat from the Russians allowed the Ottomans to concentrate resources on the Dardanelles. Russian mine fields, void of reseeding and with no protection from poaching were charted and became supplies for the Ottoman fields in the Dardanelles. The Russian contribution to the Dardanelles Campaign was the H.I.M.R.S. Askold and Captain M.I. Smirnov as liaison officer. However, there seems to

${ }^{380}$ Granville Fortescue, What of the Dardanelles? (London: Hudder and Stoughton, 1915), 36 .

${ }^{381}$ Admiral Robeck would later organize cattle raids on Turkish civilians using Greek irregulars starting in 1916. The use of Greeks initiated intercommunal warfare that lasted until 1922. See Paul G. Halpern, ed., The Royal Navy in the Mediterranean 19151918 (Brookfield:Gower Publishing Company, 1987), 67-69, 329-332, 334, 340.

${ }^{382}$ Greger, 48. 
have been no coordination between the Entente fleets and their governments with similar military objectives but differing geographical ambitions. ${ }^{383}$ With the decision to alter to a ground war in the Dardanelles, the Russian Supreme War Council on 18 March vetoed any injection of Russian troops into the Dardanelles fiasco. ${ }^{384}$ The Russian Black Sea fleet was released to harass Ottoman shipping, but with no viable threat to inject Russian ground forces, the Ottomans concentrated on defense of the Gallipoli Peninsula.

The defense of the straits by the Ottoman forces was a successful bluff perpetrated upon the Entente. Operational sorties of the Russian Black Sea fleet indicated fear of the Ottoman fleet, and thus the glut of mines seeded at the Bosporus passage. The mines were to prevent passage of the Yavuz [Goeben] and Midilli [Breslau] into the Black Sea. The mines also prevented the Russian Black Sea fleet from laying siege to Istanbul via the Bosporus Strait. Souchon bluffed the Russians into operating with caution when dealing with the Yavuz. That caution led to the Russians' blocking the only passage to assist the Anglo-French forces.

The Anglo-French naval gun support proved to be a double-edged sword. The large caliber guns, necessary to destroy the gun emplacements, could not be elevated to an angle great enough to create plunging fire. In order to achieve the desired fall of shot, the battleships had to operate beyond 10,000 yards from the shore. This range decreased accuracy and prevented the utilization of secondary armament. The secondary armament

${ }^{383}$ Nerasov, 48-49.

${ }^{384} \mathrm{Ibid}$. 
on the Anglo-French battleship, in open barrettes, could elevate to an angle sufficient to create plunging fire, but at a cost of large caliber guns. The short range of the secondary armament necessitated operating within the range of Ottoman howitzers and at short range the large caliber naval guns could fire only point blank into the bluffs overlooking the Straits. The Entente faced operating far out and hoping for a direct hit, or coming in close and getting mauled. ${ }^{385}$ Entente ships ultimately did move in closer. The newer warships first were stationed 14,000 yards off the beach and ultimately ended up less than 8,000 yards. The reduced distance allowed for the deflation fire from small caliber weapons but at the cost of severe structural damage to topside command and control from returning Ottoman fire..$^{386}$

Admiral Usedom bluffed the Anglo-French forces into action that favored the Ottomans, a land campaign. The Anglo-French naval forces could not silence the fixed fortifications overlooking the straits. Usedom's construction of numerous emplacements forced Allied warships to expend great quantities of shells on all potential emplacements, active or passive. The mobile guns and the "shell game" the Ottomans perpetrated bought Usedom time to counter the mine sweepers. Additionally, the Ottoman fixed fortifications were earthen redoubts as well as concrete. The Anglo-French fleet shelling

${ }^{385}$ For a detailed review of Entente naval gunfire at Gallipoli, see Walter C. Ansel, "Naval Gunfire in Support of Landings: Lessons from Gallipoli," Proceedings (July 1932), 1001-1010.

${ }^{386}$ For an excellent, first hand report of the damage caused by plunging fire, see Lieutenant D.D. Mercer, R.N., "Ships Versus Forts: Dardanelles, March 1915," Proceedings (October 1932), 1453-1457. 
damaged the concrete but the earthen works survived all but direct hits. The survivability of the earthen forts created difficulties not anticipated and Commander Keyes, Chief of Staff to Admiral Carden, wrote to his wife that the enterprise was a "...bigger thing than we anticipated and harder than the Admiralty realized." ${ }^{1387}$

In addition to the Dardanelles mining operation, separate mining of the Suez Canal by Ottoman forces was attempted on 11 April 1915. The operation was overt more than covert. The mines were carried over land from Syria and planted in the fairway. But the desired effect, diverting resources from the Gallipoli campaign, did not materialize. ${ }^{388}$ Ottoman naval personnel also mined the Karum River in Persian Arabistan, along with the Euphrates River above Kurnah in an attempt to slow the British advance in Mesopotamia. ${ }^{389}$

When comparing the Dardanelles mining operation to the Russian Black Sea and the Anglo-American North Sea fields, it can be seen that the Ottomans achieved total closure with far fewer resources. The Dardanelles defense depended upon threat of mines as a deterrent whereas the North Sea and Black Sea relied on sheer numbers to achieve closure. Table 27 compares the total number of mines laid during World War I. 102-105.

${ }^{387}$ Keyes to his wife, 8 March 1915. Found in Halpern, The Keyes Papers, Vol. I,

${ }^{388}$ Vice Admiral Richard Peirse to Vide Admiral Arthur Limpus, 18 April 1915, found in Halpern, The Royal Navy in the Mediterranean, 12.

${ }^{380}$ Julian S. Corbet, Naval Operations, Vol. III (London: Longman, Green and Co., 1923), 11-17. 


\section{TABLE 27}

\section{MINES LAID DURING WORLD WAR I}

\section{$\underline{\text { Location }}$}

\section{Total Number Laid}

Dardanelles

North Sea

Black Sea

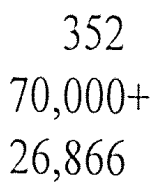

Source: James A. Meacham, "Four Mining Campaigns: An Historical Analysis of the Decisions of the Commanders," Naval War College Review, Vol. XIX, No. 10 (June 1967), 84, 91; and René Greger, The Russian Fleet, 1914-1917 (London: Ian Allan Ltd., 1972), 71 .

Admiral Usedom bluffed the Anglo-French forces away from a naval campaign just as the Ottomans were running out of ammunition. The English shipyard, Armstrongs, was to have delivered a shipment of ammunition for the Dardanelles fortifications as well as for the battleship Sultan Osman-i Evvel. England seized both the ship and ammunition, creating a shell shortage, necessitating good firing discipline in order to conserve what was available. Reports concerning ammunition on hand by Djevad Pasha, the Ottoman commander overseeing fortifications, are found in Table $28{ }^{390}$ The ammunition remaining on 18 March 1915 would have been sufficient to withstand two additional attempts to force the Dardanelles. ${ }^{391}$

${ }^{300}$ Winston S. Churchill, The World Crisis, Vol. I (New York: Scribner's, 1923), 263.

${ }^{391} I$ Ibid., 264. 


\section{TABLE 28}

OTTOMAN GUNS AND AMMUNITION AFTER 18 MARCH 1915

\section{Diameter (in inches)}

14 naval guns

9.4

6 quick firing

8.2 mortars

6 Howitzers

5 or less

\section{Number of Guns}

5

14

8

18

32

$70+$

\section{Shells Available}

271

868

371

720

3706

NA

Source: Winston S. Churchill, The World Crisis, Vol. I (New York: Scribner's, 1923), 263.

A combination of four defensive measures confronted the Anglo-French forces attempting to traverse the Dardanelles: forts, mobile howitzers, minefield batteries and minefields. All were all good, but mutually dependent. The minefields blocked the passage of the straits and kept the fleet beyond their limits. The minefield batteries prevented the sweeping of the minefields. The forts protected the minefield batteries by keeping battleships at a distance with long range coastal batteries. The mobile howitzers kept the battleships on the move and increased the difficulty of overcoming the forts. So long as all four factors stood together, the defenses constituted a formidable obstruction. But not one could stand alone, and if one were broken, the fall would entail the collapse of the others.

Ottoman grit stood the challenge with help from Germany. Any assistance provided by Berlin was technical, not material. Direct and unencumbered communication with Germany was possible only after Bulgaria joined the Central 
Powers on 6 October 1915.

The Ottoman navy maintained the minefields once the conflict switched to a ground campaign, and the Anglo-French naval forces did not challenge the straits for the duration of the war. But on 13 May 1915 the Ottoman destroyer Muavent-i Milliye, captained by the German Captain Firle, torpedoed the British battleship HMS Goliath and returned unscratched: the first recorded successful torpedo attack by a destroyer on a battleship. ${ }^{392}$ The Anglo-French forces so discounted the Ottoman navy that patrols to prevent such attacks were not maintained. ${ }^{393}$

The defense of the Dardanelles can be attributed to resolve: the Ottomans would not concede. The Anglo-French forces underestimated the Ottomans and overestimated the worth of naval gunfire. When Allied victory could have been achieved, Admiral de Robeck could not face losing ships. The Ottomans were able to turn the Allies from naval forces in which the Entente had superiority, to the Ottoman strength: ground forces. The failure led to the impression that modern coast defense guns along with landbased aircraft would slaughter any landing force before the surf zone. Such views, fostered by the Dardanelles campaign, would suppress amphibious evolution until World War II.

${ }^{392}$ Hovgaard, 18.

${ }^{393}$ Güleryüz, 31 . 


\section{CHAPTER VIII}

\section{BLACK SEA ACTION, 1914-1918}

The Ottoman Empire had enjoyed the Black Sea as its own private lake for several centuries. A map of the Black Sea Region is found in Appendix 9. The relationship provided a secure region in which the Empire conducted trade and transportation with little fear of disruption except from nature. The security and peace would change forever when Russia looked south for ice-free exits to the West. The potential threat from Czarist expansion schemes forced Istanbul to maintain fleet units capable of interdiction and blockage of waterborne aggression. The Sultan's government may have been concerned with ethnic uprisings in the Empire, but Russian aggression via the Black Sea was a paramount concern that dictated Ottoman naval policy for more than two centuries.

In order to understand fully the naval situation in the Black Sea, the historical account of Russian southern expansion needs to be examined. Although Russia appeared on the Eastern political scene in the ninth century, there was no major friction with the Ottoman Empire beyond limited border raids. It was not until the reign of Peter the Great (1682-1725) that Russia exhibited any real interest in extending its southern boundaries.

Determined to establish a foothold on the Black Sea and gain access to warm water ports of the Mediterranean, Peter captured the Ottoman Black Sea fortress of Azov in 1696.

Russian occupation with the Russo-Swedish War and the alliance between Sultan Ahmed III (1703-1730) and Charles XII of Sweden (1697-1718) allowed the Ottomans to regain 
possession of Azov in 1711.

New Russian aspirations in gaining a foothold in the Mediterranean began to take form in the eighteen century. Occurrences centered around the four factors: evolution of Western Powers into world powers; the rise of Czarist expansionism; the decline of Ottoman military prowess; and the counteraction of Western power to Russia's southern expansion. $^{394}$

Russia's Catherine the Great (1763-1796) continued the push towards the Middle East. When Russia became entangled with the Poles, the Ottomans declared war on Russia. Catherine then dispatched the Baltic fleet around Europe and annihilated the Ottoman Navy at Chesme. The Russian fleet continued "mopping up" operations in the Aegean Sea, and in 1772 occupied Beirut, where the Russian flag flew for five months. ${ }^{395}$ Although the naval effort failed to penetrate the Dardanelles, the treaty concluded in 1774, coupled with subsequent military ground pressure on the Ottoman Empire, gained Russia additional territory and free navigation in the Black Sea. ${ }^{396}$

The arrival in 1798 of the French General Napoleon Bonaparte in the Middle East resulted in the first defensive alliance between Russia and the Ottomans, in which Russia was granted free passage through the Straits and the strategic waterway was closed to the warships of other foreign powers. By 1812 the French interest in Middle Eastern

${ }^{394}$ Charles Moran, The Sea of Memories (New York: Scribner, 1942), 247-248.

${ }^{395}$ Ivan Spector, The Soviet Union and the Muslim World (Seattle: University of Washington Press, 1959), 6-7.

${ }^{306}$ George Lenczowski, The Middle East in World Affairs, 3rd ed. (Ithaca, NY: Cornell University Press, 1962), 11. 
adventures had ceased, and Russia's aggressive southward expansion resumed. Britain, with commercial interests in the Mediterranean, saw the need to promote actively the integrity of the Ottoman Empire. Istanbul's appeals to the Greater Powers for regulations to operate the Straits resulted in a neutralization policy in the Treaty of 1809 . Russia was denied military access to the Mediterranean via the Dardanelles; however, St. Petersburg was assured no hostile fleet would attack its Black Sea possessions. ${ }^{397}$

In 1832 the Ottoman Empire faced attack by Egyptian Mehemet Ali Pasha (18051849). The Russian fleet came to the Sultan's aide and, according to the Unkiar Iskelessi Treaty that followed, Russia became "guardian" of the Straits and the Ottoman Empire became dependent upon its powerful northern neighbor. ${ }^{398}$ A later war between the Ottoman Empire and Egypt resulted in the intervention of Western European powers, principally England. With concern over Russian intrusion in Istanbul, the Straits Convention of 1841 checked Russian influence and placed the Ottoman Empire under Western protection. ${ }^{399}$ Western European efforts to check Russian influence in the Middle East led to the Crimean War.

The Crimean War ensued after Russia's Nicholas I (1825-1855) countered Napoleon III's (1852-1870) efforts to strengthen the French influence in the Near East with a demand for protection over Orthodox Christians throughout the Ottoman Empire. The Russian invasion of the Ottoman Empire caused England and France to declare war

${ }^{397}$ Moran, 258.

${ }^{398}$ Ibid., 259.

${ }^{309}$ Lenczowski, 17. 
in 1854. The Treaty of Paris, signed in 1856 after the fall of Sebastopol, excluded the Russian fleet from the Black Sea and restricted the construction of defense installations along the seacoast. ${ }^{400}$

In 1877 internal revolt in the Ottoman Balkan region encouraged Russia to repudiate the Black Sea clauses of the Treaty of Paris and invade via the Balkan and Caucasus regions. Russian success was assured by the Black Sea fleet's dominance. The Ottoman navy could not prevent the landing or resupply of Russian forces marching along the seacoast. Additionally, fear that Russia might bring the Baltic fleet around Western Europe and lay siege upon the Straits prevented redeployment of Ottoman warships from the Sea of Marmara. England, once assured that Russia had no outward plans upon Egypt or the Suez Canal, refused to come to the aide of the Ottomans. ${ }^{401}$

Russian military gains were not followed by diplomatic success. The Treaty of San Stefano in 1878 awarded Bulgaria and thus Russia with territory and influence that would have upset the balance of power in the Near East. England forced a modification of the treaty, saving European Ottoman possessions and Istanbul rewarded England with Cyprus. With the occupation of Egypt in 1878, English control was thus substituted for Ottoman power at the crossroads of the Levant. England had no vital interest in Cyprus prior to 1869 and the opening of the Suez Canal. Cyprus was desirable to protect English gains in the Near East and to block any possible Russian advances into the Mediter-

${ }^{400}$ Güleryüz, 4.

${ }^{401} I$ Ibid., 5. 
ranean. ${ }^{402}$ British concerns for Russian expansion from the Black to the Mediterranean Seas goes back to Lord Nelson in 1799, who wrote, "The Russians are anxious to get to Malta, and they care for nothing else."1403

Fear of Russian advances towards the Mediterranean and the Middle East led to the Second Mediterranean Agreement in December 1887. The agreement concerned the possible military occupation of some Ottoman territory, ostensibly in order to preserve the independence of the Empire, by Britain, France, and Russia. The agreement clarified British opposition to both Russian encroachment into the Mediterranean and French inroads into Syria.

The twentieth century dawned upon an Ottoman Empire confronting an injured Russia reeling from a disastrous war with Japan. The Russian Black Sea fleet was prevented from sailing to aid the Baltic fleet because of the Ottoman refusal to allow foreign warships through the Straits. ${ }^{404}$ The refusal to allow passage through the Straits increased Russian desires to control the watercourse. The complete defeat of the Russian fleet by Japan at Tsu-Shima in 1905 would not have been unavoidable had the Ottomans relented and allowed passage of the Russian Black Sea fleet. But the opportunity to lay the blame on Istanbul and not credit Japanese naval advances or Russian incompetence was advantageous.

402Bernard Newman, Mediterranean Background (London: Hale, 1949), 192.

${ }^{403}$ Quote found in John Maffee, "Ivan Hugs Shores of Tripoli," The Washington Post 25 February 1969.

404The New York Times, 8 January 1904. 
Material inferiority was not the only issue confronting St. Petersburg. The Russian officer corps was bloated, and many lacked the desire to perfect the personnel and crew training necessary to achieve a level of attainment. The living environment on Russian ships was harsh by Western standards, with hazing by senior crew members horrific. The combination of low pay, hazing, and substandard living conditions fermented into discontent. ${ }^{405}$ A mutiny in June 1905 on the battleship Potemkin, along with the training ship Prut, cruiser Ochakov, and destroyer Svirepy, and the unwillingness of the crews of other ships in the Black Sea fleet to suppress the mutineers showed the unreliability of the personnel. The unprofessionalism in the Russian fleet necessitated fleet-widel reforms as well as replacement of ships lost at Tsu-Shima.

Russian visions of exploiting the ice-free Black Sea ports were stifled by non-control of the Straits. The Ottoman policy of excluding passage of warships did hurt the Russo-Japanese War effort but also allowed St. Petersburg the luxury of having a relatively secure southern border. The commercial outlets were open without disruption except during short periods of warfare, and Russian naval funds that were expended for the Black Sea fleet went more for coast guard duties than actual blue water warships.

The situation for the Russian Black Sea fleet changed in 1906. In order to force the Straits and not be deprived of ice-free passage of both commercial and military warships, the Russian Naval General Staff (GENMOR) suggested an expansion program in order to have on hand naval forces half again the combined assets of the Black Sea

${ }^{405}$ F.O. 371/1469/20817, O'Beirne to Grey, 12 May 1912, St. Petersburg, cited in Halpern, The Mediterranean Naval Situation, 301. 
powers. Table 29 lists the 1906 Russian assets and the proposed Black Sea fleet.

TABLE 29

PROPOSED EXPANSION OF RUSSIAN BLACK SEA FLEET

$1906 \quad$ Proposed Additions

Battleships

Cruisers

$6+3$

Destroyers

2

Gunboats

Submarines

19

6

$0+3$

Source: René Greger, The Russian Fleet, 1914-1917 (London: Ian Allan Ltd., 1972), 910.

Russian naval plans were slowed by Russian economic conditions. The Russians attempted to purchase ship plans from Germany and England in order to bypass the design phase of shipbuilding. But foreign plans called for fabrication not readily available in Russian yards, and St. Petersburg was forced to acquire several ships from foreign shipyards. The deteriorating situation concerning Germany and Austria redirected funds from the Black Sea fleet to the Baltic Sea forces until late 1909.

Russian shipbuilding started modernizing along the same route that made Italy successful: foreign capital and joint ventures. The Germans established partnerships with Baltic yards and the British, the Black Sea shipbuilders. The British firm of John Brown advised the Russian yard Bunge and Ivanov at Nikolaev. ${ }^{406}$ In preparation for 
dreadnought construction, the yard was furnished with new shops, railway connections, and the latest machinery. British Vickers acquired an interest in the Ateliers et Fonderies de Nicolaieff, where the English firm started construction of the Ekaterina II in September 1912. The English firm John Brown advised on the dreadnoughts Imperatrista Maria and Imperator Alexander III in July 1912. ${ }^{407}$ The British Second Sea Lord, Prince Louis of Battenberg, encouraged English shipyards to expand and modernize the Russian Black Sea Fleet. The premise was that the Russians would act as a check on any Ottoman attempts to acquire full sovereignty over Egypt.

The Greek tycoon George Averoff contracted in October 1909 to acquire an armored cruiser and the Ottomans responded by purchasing two German battleships. Russia responded by restoring funds to the Black Sea shipyards at Nikolayev and Odessa. In April 1911 the Russian Vice Admiral Ivan K. Grigorovitch, Russian Minister of Marine, forced through a Black Sea building program that would remove any doubt about Russian dominance of the Black Sea. Table 30 shows the comparison of Russian to Ottoman naval forces in 1911.

The Ottomans responded to the Russian Black Sea buildup by ordering the Resadiye and Mahmud Resad V in June 1911. Additionally, in 1914 the Ottomans and Russians began competing negotiations with Brazil in order to purchase the two Sao Paulo-class dreadnoughts. ${ }^{408}$ The Ottomans needed the ships to confront Russian and

${ }^{407}$ Halpern, The Mediterranean Naval Situation, 298-299.

${ }^{408}$ Gardiner, 292. 
TABLE 30

\section{OTTOMAN RUSSIAN NAVAL COMPARISON}

\section{$\underline{\text { Russia }}$}

Dreadnoughts

Pre-dreadnoughts

Armored cruisers

Protected cruisers

Destroyers

Torpedo boats

Submarines
Ottoman Empire

$\begin{array}{lc}3 \text { (building) } & 2 \text { (building) } \\ 6 & 1 \\ 1 & \mathrm{NA} \\ 1 & 2 \\ 26 & 8 \\ 14 & 9 \\ 11 & \mathrm{NA}\end{array}$

Source: Fred T. Jane, ed. Jane's Fighting Ships, 1914 (London: Sampson Low Marston, 1914; reprint, New York: Arco Publishing Company, 1969), 411, 409.

Greek expansion plans, the Russians wanted to prevent the Ottomans from acquiring the ships. The Russians needed to prevent the Ottomans from dominating the Black Sea prior to the completion of the new Nikolayev battleships. Ottoman naval plans were not directed towards Russian but Greek imperialism. However, Russia, in attempting to influence events during the Italo-Ottoman and Balkan Wars, found the Russian Black Sea fleet incapable of intimidating the C.U.P. in Istanbul or Slavic ally Bulgaria.

In an attempt to "stabilize" the situation, the Great European Powers dispatched a strong naval force to Istanbul. The Russians were represented by an old battleship, a cruiser, and a gunboat. The Russian warships originated from the Black Sea, and other European powers provided warships from Mediterranean squadrons or fleets. The Russian Black Sea Fleet Chief of Staff officer, Captain Ivan Kononov, suggested dispatching several large, deep draft battleships to the Mediterranean, forming a 
squadron, and then claiming a right to take the ships to the Black Sea for dry docking or major maintenance. The warships could become involved in shipyard "accidents," preventing a timely departure and thus circumventing the Treaty of Paris. The warships from the Baltic would balance out Ottoman purchases abroad and provide relief to the Black Sea naval imbalance. ${ }^{409}$

The Russian Black Sea fleet was never regarded as a main player in any prewar planning. ${ }^{410}$ The Ottoman-Russian diplomatic situation was fairly straightforward. Russia would interfere with the internal politics of the Ottoman Empire through ethnic Armenians in the east while seeking out foreign cooperation over the Straits question. Russia had been exerting considerable pressure on Istanbul to remain neutral in the event of a general European war, but, like England and France, refused to give any guarantees to respect Ottoman borders. Following the visit of the Czar to Constanza and Bucharest in June, Russia and Rumania agreed to cooperate in the event of the closure of the Straits. Russia also encouraged Rumania and Bulgaria to take action to "disturb the Turks." Any Russian naval operations in the Black Sea theater were considered ancillary to the main battlefront in central Europe. The 1908 plan set the chief objectives of the Black Sea fleet as annihilation of the Ottoman fleet and for landing at the Bosporus. A year later, in 1909, a variation on this plan allowed for the appearance of the Austro-Hungarian fleet allied to the Ottomans. Mastery of the Black Sea was to be

${ }^{409}$ Nekrasov, 12-13.

${ }^{410}$ Greger, 12.

"I'Güleryüz, 27. 
ensured by blocking of the Bosporus with 2300 mines laid in three fields. ${ }^{412}$

The expected strengthening of the Ottoman fleet with ships ordered from England, Italy and France led to a radical alteration in the 1909 plans. In the 1912 plan, the Bosporus blockade was omitted, and the 1917 plan expected the Ottomans to strike first around Sebastopol, placing the Russians on the defensive until the new battleships came on line. ${ }^{413}$ The Russian Black Sea commander, Vice Admiral Andrei von Ebergard, fully expected to wage a defensive battle with the forces of a weaker naval power: submarines, small torpedo boats, destroyers, and naval aviation. Ebergard planned also on defensive mining along the routes to Sebastopol and Novorossisk and offensive mining at the Bosporus Strait. Port Arthur proved defensive mines could shape a theater or deny the use of shipping channels and the lessons of the Russo-Japanese War were utilized to formulate Ebergard's the mining plans. ${ }^{414}$

Russia sought assistance for the Black Sea through Paris when Russian Vice Admiral Aubert and Vice Admiral Prince Lieven worked out a general agreement for collaboration with French Minister of Marine Delcassé. The Russian Minister of Marine, the Vice Admiral Ivan K. Grigorovitch, needed time to rebuild, and France had shown a willingness to enter into a military understanding. The Franco-Russian naval convention of 16 July 1912 called for aid during wartime against a mutual foe. The gist of the treaty called for the maintenance of Russian naval supremacy in the Black Sea in order to secure

${ }^{412}$ Greger, 12.

${ }^{413} \mathrm{Ibid}$.

${ }^{414}$ Nekrasov, 26. 
transport of troops and supplies for land operations. Troops stationed in the lower

Caucasus region would be transported via waterways to the Ukraine or vice-versa. But the Russians feared the situation would completely change if the Austrian or Italian fleet, or both, were allowed by treaty or persuasion to pass through the Strait. Delcassé and the French admirals had planned on concentrating forces at Bizerte in order to check the Italian or Austrian fleets. Actually the French had promised nothing that Paris did not intend to do in the first place. French naval plans called for checking either Triple Alliance member at Bizerte regardless of Russia. ${ }^{415}$

The Russian threat in the Black Sea was a fact the Ottomans had to contend with. However, Romania and Bulgaria also attempted to create respectable navies capable of striking off shore. When Bulgaria received full independence on 5 October 1908, Russia offered to sell the Bulgarian navy a cruiser, two popovkas-class gunboats, minelayers, torpedo boats and auxiliaries. The Bulgarians declined the offer on the grounds that a large fleet was unnecessary. Russia could always be counted on for assistance, and such a large force would only drain the cash-strapped country. Bulgaria was satisfied with small auxiliaries for coastal defense and concentrated on land warfare. ${ }^{416}$

Romania had gained independence in 1880 and with little coast line on the Black Sea, emphasized river patrol boats on the Danube estuary. The 1899 naval expansion program had called for six coastal battleships, four destroyers and twelve torpedo boats.

${ }^{415}$ Halpern, The Mediterranean Naval Situation, 304.

${ }^{416}$ Gardiner, 411. 
The Danube Division was slated to be strengthened by eight river monitors and twelve river torpedo boats. The aggressive buildup in the Danube River signified the importance of Danube security to Romania, and the actual purchase of four river monitors and eight river torpedo boats the difficulties in funding.

The Romanian 1899 naval program, folded into the 1912 program, called for six light cruisers, twelve large destroyers, and one submarine. Subsequent plans called for naval expansion totally out of financial reality for Romania, a coastal battleship of 13,000 tons and ancillary units. ${ }^{417}$ Romania did order four Aquila-class destroyers from Pattison in Naples, Italy in 1913. How Romania was going to transit the ships through the Ottoman-controlled Straits is not clear. But Romania had sided with Istanbul in the Third Balkan War and forced Bulgaria to fight on two fronts. The splitting of Bulgaria's forces ultimately led to the recapture of Western Thrace and saving the C.U.P.'s regime. The "unobserved" passage of the Romanian destroyers would have been a small price to pay for the defeat of Bulgaria. Romania did possess a merchant marine of 41 steamers of 75,174 gross tons, of which four vessels had been outfitted as auxiliary cruisers.

The Ottoman Fleet commander, as of 1 October 1914, was Admiral Wilhelm Souchon, and the second in command was Admiral Arif. Ottoman fleet assets were divided into two squadrons, each with a destroyer and torpedo-boat component. Additionally, a mine group under Captain Nazmi Emin was formed for both defensive sweeping and mine seeding. Appendix 10 shows the breakdown of Ottoman assets as of 
1 October 1914.

The Ottoman-German fleet commanded by Souchon had only one hope for victory, a quick, decisive strike. The Ottoman naval situation would be favorable only until the Russian dreadnoughts were completed. After the new Russian dreadnought became active, the Russians would quickly entrap the Ottoman-German fleet. So success for the Ottoman-German fleet dictated a knockout punch delivered by sea prior to the activation of these dreadnoughts. Additionally, Souchon and the German ambassador, Baron von Wangenheim, were concerned that since the Battle of the Marne on 5 September 1914, German forces had been on the defensive. In the east, Austrian forces had been repulsed by Russian troops in the Ukraine region. Germany was under severe stress, and an offensive in the Black Sea and southern Caucasus region could relieve pressure on Austria and Germany. The Ottomans fully understood that a victorious Russia would mean disaster for the Ottoman Empire for closing the Straits and thus severing Russia's supply lines. No country could prevent the dismemberment of the Ottoman Empire except a victorious Germany and to defeat Russia and save Germany, Souchon had to defeat the Russian Black Sea fleet. In order to prod Russia into attacking the Ottoman Empire, Souchon ordered the Midilli and several torpedo boats into the Black Sea on 20 September $1914 .^{418}$

${ }^{418}$ File No. 711.673/42, Morgenthau to Secretary of State, United States, 20 September 1914, Istanbul. Found in United States, Papers Relating to the Foreign Relations of the United States, Supplement (Washington, DC: Government Printing Office, 1928), 111. 
In order not to provoke a war, Ebergard was ordered not to sortie in the southern reaches of the Black Sea. The first order for the Russian Fleet was to secure the coast of the Black Sea in order to prevent landings of Alliance troops. For the Ottomans, the path to intervention into the war was concluded on 11 October when Enver, Talaat, Djemel and Ottoman Foreign Minister Halil agreed to hostilities in exchange for $\$ 9,620,000$ in gold from Berlin. The death of King Carol of Romania momentarily slowed the process due to the belief that a Bulgarian-Romanian-Ottoman defense agreement could be arranged via Romania, however, by 21 October Germany had shipped the agreed-upon price. $^{419}$

The decision to sortie out on 27 October was decided at a conference attended by the Ottoman ministers and the German ambassador von Wangenheim. Wangenheim insisted the Ottomans strike at Russia immediately. Ottoman Grand Vizier Said Halim resisted, claiming the slow Ottoman mobilization had not proceeded far enough to allow offensive action. Said Halim planned on the European war bleeding both sides white. Neutrality until 1918 would allow for a German-trained army of almost one million, making dismemberment of the Ottoman Empire doubtful. However, under pressure from Ottoman War Minister Enver Pasha and Wangenheim, the Grand Vizier gave permission for Souchon to sortie into the Black Sea, but not attack the Russians. Souchon's instructions were to sail and to defend if attacked, but not to draw the Ottomans into the 
war. ${ }^{420}$ Additionally, Crown Prince Izzedin, heir to the throne, brother of Abdul Hamid, was very clear that no declaration of war should be made without consent and approval of the ruling council, and the majority of that body opposed entering the war. Enver, in dispatches to Wangenheim, had planned an attack on the Russian Black Sea Fleet without a declaration of war. Naval Minister, Djemal Pasha, the head of the Ottoman Fleet, was left out of the fleet war plans. ${ }^{421}$

The Ottoman navy, commanded by Souchon, sortied out of the Bosporus Strait on 27 October 1914 from an anchorage off Haydarpasa, Buyukdere, and Istine and assembled within the breakwaters. At 1700 hours, the visual signal, "Do the utmost for the future of Turkey" was sent three times, and the fleet sailed out into the Black Sea. ${ }^{422}$ Secret orders instructed the commanding officers to proceed to Russian waters and strike at the Russian Black Sea fleet. "The Turkish fleet is to achieve naval supremacy in the Black Sea. Seek out the Russian fleet and attack it wherever you find it without declaration of war. ${ }^{1423}$ Souchon learned from intelligence that the Russian fleet had just returned to Sebastopol to coal after a cruise. Souchon planned on mining the harbor entrance, trapping the Russians and systematically destroying the berthed ships. Any ship fleeing the bombardment would have to navigate a dense minefield and the sec-

${ }^{420}$ Djemel, 112, 127-132.

${ }^{421}$ Trumpener, 51-52.

${ }^{422}$ This Signal is not found in Ottoman signal books in use in 1914. See Turkish Naval Forces Command Culture Publications, Translated by Tayfun Isevi. Ottoman Navy Signal Code Book (Ankara: Naval Forces HQ Press, 1995).

${ }^{423}$ Trumpener, $51-52$. 
ondary armament of the Yavuz. ${ }^{424}$

On 29 October 1914 Yavuz, along with escorts Tasoz and Samsun, arrived off Sebastopol, and at 0630 hours they opened fire. Russian shore batteries returned fire, and Yavuz was hit three times near the funnel, forcing a withdrawal after doing little damage to the Russian fleet. While returning to Istanbul, Yavuz captured the Russian steamer Ida, sank the Russian minelayer Prut, and damaged an escorting destroyer Leytenant Puschkin. Yavuz arrived back in Istanbul on 30 October after doing little damage to the Russian fleet.

In addition to the Yavuz, Tasoz, and Samsun, the Ottoman passenger liner Nilufer was painted to resemble a Russian steamboat with black hull and yellow funnel and was outfitted with mine rails and sixty mines. The Nilufer laid a mine barrage off Sebastopol, closing the channel and preventing the Russian Black Sea fleet from pursuing the Yavuz and her escorts.

Another squadron led by the Hamidiye arrived off Feodosia at 0630 hours, and an Ottoman and German officer were sent ashore to inform local authorities that hostilities would begin in two hours. Chivalrously, Hamidiye waited until 0900 hours before opening fire and shelled the harbor installations for an hour before steaming to Yalta. At Yalta, Hamidiye sank the steamer Sura and the sailing vessel Svyatoy Nikolav before returning to Istanbul on the 31 October.

${ }^{424} J$ ulian Stafford Corbett, Naval Operations, Vol. I (London: Longmans, Green and Co., 1920), 360. 
The Gayret-i Vataniye and Muavent-i Milliye arrived off Odessa at 0230 hours on 29 October. A small line of boats making its way into the harbor was attacked, and the Russian gunboat Donets was sunk and the Kuranet damaged. The Muavent-i Milliye shelled the oil tanks and harbor installations, and damaged a berthed merchant ship. Russian shore batteries prevented a planned landing to destroy grain installations, and the two warships returned to Istanbul via the Snake Islands.

The Midilli and Berk-i Satvet arrived off Novorossiysk after a rough passage during which the crews experienced severe sea sickness. An officer from the Berk-i Satvet was sent ashore to warn authorities of the intended attack but the Russians refused to accept the warning and arrested the officer. The Berk-i Satvet entered the harbor and communicated that shelling would commence immediately if the emissary were not freed. The officer was released, and the Berk-i Satvet generously waited until 1050 hours before opening fire on the shore installations. The Midilli laid a sixty-mine barrage in the Straits of Kerch before assisting the Berk-i Satvet in shelling Novorossiysk. After destroying the oil facilities there, the Ottoman warships targeted the merchant piers, resulting in seven ships being damaged and the Nikolai sunk. At 1300 hours, Midilli departed Novorossiysk and sortied to Varna to destroy the telegraph to Sebastopol. Both ships were back in Istanbul by 30 October.

In reviewing the operations carried out against Sebastopol, Feodosia, and Odessa, the Ottoman commanders agreed that none had succeeded in damaging the Russian fleet or hampering Petrograd's war machine. ( Czar Nicholas II changed the German "St. Petersburg" to the Russian "Petrograd" at the outset of the war. ) The loss of two small 
warships and several merchants would not adversely affect the Russian fleet. The German officers voiced a low opinion of the Ottoman Navy in general but praised the ordinary Ottoman seamen for their bravery and hard work during the action, especially since the fleet had little real sea training. The German crews, however, had their own problems, and Souchon's orders of the day state, "that feigned illness is cowardice in the face of the enemy." The order was read in German and was addressed only to the German crews.

The attack led to Russia's declaring war on the Ottomans on 2 November 1914, followed by Great Britain and France on 5 November. Russian offensive action against the Straits and the Anatolian coast began on 5 November 1914 with the mining and shelling of the coal port of Zonguldak. Ottoman losses began with the sinking of the loaded troop transports Bahriye Amer, Bezm-i Alem, and Mithat Pasa off of Kandilli. The loss of almost a division of well-trained X Army Corps troops headed to Trabzon was a result of the lack of communications between Souchon and Enver Pasha or of overconfidence on the part of Souchon. Miscommunication, differences in priorities, Enver's ground defense in the Caucus, and Souchon's views of the Russian Black Sea fleet created confusion and delay that cost the Ottomans troops, ships, and opportunities for success. However, Souchon's complaints of time schedule differences had some validity. The Ottoman Empire did not utilize standard Western European methods of hourly time or yearly calendars. The Ottoman-fixed element for time was sunset, not noon, as in Western European practices. Using sunset was necessary for daily prayers. Additionally, three different calendars were in active use in the Empire: the lunar, the Julian, and the Gregorian. All three differ from the Roman calendar used in western 
Europe. Unless Souchon was fully aware of the possible time differences, confusion would be probable. ${ }^{425}$ Souchon's inactivity suggest he may have believed the Russians would hunker down as in Port Arthur during the Russo-Japanese War. Ebergard planned on the exact opposite.

Souchon did provide convoy protection for X Army Corps after the loss of the three transports. But the loss of the three large transports slowed the Army's deployment, and convoy duty prevented offensive action against Russian naval targets. Compounding the situation was the condition of Ottoman warships. Other than the Yavuz and the Midilli, no Ottoman warship could do over twenty knots, slowing the faster ships down to keep with the slowest. Russia economics delayed building dreadnoughts in the Black Sea and Eberhard had to settle for large oil fired destroyers instead. Conventional naval doctrine would have viewed the destroyers as less an asset than dreadnoughts but the action in the Black Sea showed large destroyers were ideal for the theater.

The Yavuz rejoined the fleet after repairs were completed to the battle-damaged superstructure in mid-November. On 18 November Yavuz, with the Midilli as escort, encountered a Russian squadron off the Crimea. Ebergard respected the Yavuz and would only duel when the Russian fleet was at a numerically superior position. The Yavuz opened fire, but it was hit by returning fire on the port casement III, and sixteen sailors were killed. The Russian battleship Evstafiy was hit four times and retired out of the firing line leaving Ebergard outgunned, and he withdrew. Ebergard switched to 
offensive mining in the belief that the fields could bottle up the Ottoman fleet.

Ebergard needed to stall for time until the three Impertritsa Mariya-class dreadnoughts became operational. The Yavuz had proved vulnerable to shellfire but also reaffirmed that German naval engineering had created a warship capable of taking as well as delivering a hit. Ebergard chanced that a huge minefield outside of the Bosporus opening could create enough havoc to damage the deep-draft Yavuz. Table 31 lists the number and general type of offensive mines seeded by the Russian Black Sea fleet along the Anatolian coast during the war. In addition to offensive mines, Ebergard laid a defensive mine barrier along the northern Black Sea coast involving 4,423 mines by the end of 1914. The Russians had been experiencing major setbacks fighting the Germans on the eastern front, and the prospect of a German-inspired amphibious landing, and not the Yavuz and Midilli, concerned Ebergard. ${ }^{426}$ In order to improve the odds that the Yavuz might hit a mine, Ebergard intended to sink block ships in the channel, either narrowing it to make the odds of a successful mining greater, or blocking it completely and thereby bottling up the entire Ottoman deep-draft fleet.

From mid-November until January, troops of the Ottoman X Army Corps were transported east in order to facilitate the winter Caucasus campaign planned by Enver. The Ottoman fleet provided convoy duty where necessary and harassing shore bombardments on Batum, Sebastopol, Akkerman, and Tuapsa when possible. When the convoys were protected, no transports were lost to Russian surface ships. Russian mines 
TABLE 31

RUSSIAN MINES USED IN THE BLACK SEA

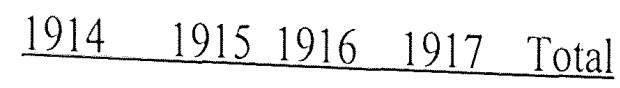

Mines seeded

$\begin{array}{lllll}1247 & 58 & 2187 & 2186 \quad 5678\end{array}$

Mine Type

Model 1912

Weight $(\mathrm{kg})$

609

480

582

Explosive Weight $(\mathrm{kg})$

Model 1909

Model 1908

450

100

Model 1906

River Type (Little Fishes)

130

115

55

30

Source: Robert Gardiner, ed., Conway's All The World's Fighting Ships, 1906-1921 (London: Conway Maritime Press, 1985; reprint, London: Conway Maritime Press, 1992), 416-417.

claimed few successes because the "throw-and-go" method of seeding was inadequate for complete blockade and because the Russian were unable to prevent Ottoman minesweeping. But on 26 December the Yavuz hit two recently laid mines just outside the Bosporus. Over 600 tons of water flooded the forward section but trim was unaffected and the ship returned to port safely. ${ }^{427}$ The ship's compartmentalization was excellent. The damage to the Yavuz was costly. Ottoman facilities were inadequate to implement repairs, and the ship would be unable to sortie until April 1915.

${ }^{427}$ Güleryüz, 46. 


\section{$\underline{1915}$}

The new year 1915 found the Ottoman fleet without the services of the Yavuz and the Russian fleet preparing to place into service the dreadnought Imperatriysa Mariya. The mine campaign instituted by Ebergard had begun to show success not only on the Yavuz, but also the cruiser Berk-i Satvet and the minesweeper Ron and mine layer Nilufer. The warships were damaged beyond repair and would sit out the rest of the war. Ebergard took advantage of the absence of the Yavuz by releasing the old pre-dreadnoughts to shell the Anatolian coast, concentrating on the coal facilities at Zonguldak and Eregi. In an effort to stifle the Istanbul economy, Ebergard concentrated on merchants plying the Anatolian coast.

After the new year, Souchon decided to reinforce Zonguldak with four $12.0 \mathrm{~cm}$ coastal defense guns. The guns were sent to be transported by the Yesilirmak with protection provided by the Midilli, the Hamidiye, and the Berk-i Satvek while en route to Zonguldak. At 1800 hours, the Berk-i Satvek hit a mine, resulting in general flooding aft. Two tugs towed the warship back to Istinye, where the cruiser sat out the war because of lack of repair facilities. The Russians intercepted Ottoman radio communications and dispatched five battleships, two cruisers, and ten destroyers in the hope of catching the Midilli and the Hamidiye. Missing the Ottoman cruisers, Ebergard scoured the Anatolian coast, destroying 51 merchant vessels. ${ }^{428}$ 
Enver's Caucasus campaign had become a rout by 24 January 1915 and the remnants of the X Army Corps trickled to the Lazistan coast in the hope of being rescued. The Russians bombarded the coastline, preventing succor or rescue. In addition to the Ottomans, the Russians went after neutral American shipping charted to the Red Cross. The American steamer Vastinton, transporting medical supplies to Trabzon, was sunk on 8 February. The Ottoman navy could not protect the merchants and fight the war at the same time. In less than two months, the Russians had sunk over 100 Ottoman merchant ships, and the shortage of coal warranted rationing, which led to economic stress on the war effort.

Istanbul got a reprieve when the Russian Supreme War Council, on 9 February, forbade the Black Sea fleet from leaving Sebastopol unless the situation with regard to the Allied attack on the Dardanelles required assistance. ${ }^{429}$ All Ottoman warships in the Black Sea returned to the Straits in order to await the Entente thrust up the Dardanelles. The Russians anticipated landing the V Caucasian Corps of 37,000 men around the Straits by mid-April. The troops were to be transported from Batum to the Bosporus, where the Russians expected to realize the plan of acquiring the Straits via English and French naval power.

The failed attempt to force the Dardanelles by England and France necessitated a change of plans for the Russians. Transporting of troops was shelved, and the notion of a forcible amphibious operation around the Bosporus region was put on hold. On 28 
March the world's first carrier-battleship task force arrived off the Bosporus and began shelling defensive positions outside the Strait. Seaplanes from the Russian seaplane carriers Almaz and Nikola bombed the lighthouses at Rumelifenerli and Anadolufenrli. Accompanying the Russian task force were six high seas minesweepers. Ebergard had assembled forces capable of forcing the Bosporus if the minesweepers could clear a channel and if the seaplanes found a safe route through the Russian offensive "throw-and-go" field. The mining techniques used by the Russians and the inability to maintain the fields had prevented the Russians from knowing exactly where the mines were seeded. After shelling the defensive positions with little success and with no forcible break in the thick fog, which prevented seaplanes reconnoitering through the minefields, Ebergard opted to shell coal facilities at Eregli, Kozlu and Zonguldak. ${ }^{430}$

The Yavuz returned to action on 1 April, and, along with the Midilli, sailed for Sebastopol while the Hamidiye and the Mecidiye, with the Yadigar-i Milley sortied towards Odessa. At 0630 hours off Odessa, the Mecidiye was mined, flooding the boiler rooms. The Mecidiye sank, partly submerged in shallow water, with a loss of 26 crew killed. All logs and ciphers, radio equipment, and sighting gear were destroyed before the ship sank. The Yadiggr-i Millet torpedoed the wreck, and the remaining ships returned to the Bosporus. While returning to Istinye, the Yavuz sank two Russian freighters and damaged another. Even with the Yavuz back in action, Souchon was unable to hit the enemy hard. Even the attempt to sink the Mecidiye failed, and the Russians 
raised the cruiser, repaired it, and had it commissioned as the Prut. (Prut was the name of the Russian minelayer sunk on the first skirmish of the war.)

With the Anglo-French forces bogged down at the Dardanelles, the British Admiral Michael de Robeck, on 25 April, requested that the Russian's apply pressure upon the Bosporus to check the flow of reinforcements to Gallipoli. Ebergard responded by shelling the forts at the entrance of the Bosporus as well as at Kava Narrows. Additionally, Ebergard's ships shelled the right flank of the Chatalja line and adjacent coastal defensive positions. But shore bombardment without follow-on forces become little more than a naval menace. The German Admiral Guido von Usedom, choreographing the Dardanelles defense, was aware that the Austro-German thrust in Galicia would require Russia to expend any troops available for defense, and thus no follow-on forces would be landing after Ebergard's shelling. Additionally, Ebergard also had serious coal limitations that prevented any long-term operations off the Bosporus. ${ }^{431}$

On 2 May the Russian carrier-battleship task force arrived again at the Bosporus to renew action on the defensive positions. Russian seaplanes were used to spot for the battleship gunfire but the shelling caused little damage. Moving along the coast, the Russians shelled Igneade and Kozlu and instituted interdiction measures against Romanian smuggling. Unlike the action on 28 March, Ebergard did not attempt to sweep the channel or attempt any reconnoitering of possible passages through the minefield. The Russian decision not to apply serious pressure around the Bosporus region allowed

${ }^{43}$ IJulian Stafford Corbett, Naval Operations, Vol. II (London: Longman, Green and Co., 1921), 373-74 and 295. 
Istanbul the opportunity of mustering forces against England and France on the Gallipoli Peninsula.

The Russian fleet loitered along the Anatolian coast for four days and brought Ottoman coal transport to a complete halt. Since the outset of the war, the Ottoman merchant marine had lost over 50,000 tons of register-shipping and an unknown number of sailing vessels. By 20 May Ebergard's concentration on coal interdiction stopped regular coal supplies to Istanbul. The Russian's landed a raiding party and destroyed the coal mines, loading equipment, and power house. Camli produced a low quality coal difficult to burn but the facility was on a rail line, allowing for some resemblance of scheduled delivery. ${ }^{432}$

Ottoman naval action had been sporadic while the Yavuz was out of operation. But on 10 May the Yavuz, escorted by the Numune-i Mamyet, engaged two Russian battleships and several minesweepers. The Yavuz had planned upon engaging just the minesweepers, but radio communications brought the Russian battleships Tri Suyatiteliya and the Panteleimon into the fray. The Yavuz opened fire at 0715 hours, and the Russians returned it immediately. The Yavuz was hit twice and forced to retire. The small Russian ships shadowed down the Yavuz but did not engage. ${ }^{433}$ This engagement illustrates the true problem Souchon was facing: how to engage the enemy but avoid damage to the battle cruiser upon which Ottoman hopes of matching Russian naval strength rested.

${ }^{432}$ Güleryüz, 48.

${ }^{433}$ Ibid. 
Ebergard realized the Yavuz could not be risked, and any allusion of Ottoman superiority was gone. Istanbul had to fight on the Black Sea as a weaker power.

Russian submarines began operations along the Anatolian coast in mid-May 1915 but only two submarines were suitable for such distances: the Nerpa, and the Tjulen. Both were Krupp-Germania built Kambala-type ships delivered in 1907 and were ideal for Black Sea operations.

On 7 June a Russian task force of five battleships, three cruisers, and fourteen destroyers shelled Zonguldak and then Eregli, where the Ottoman merchant ship S.S. Progress was sunk. Near Karasu, the Russians captured the merchant Edincik and recovered the ship's log book, noting the arrival of the German submarines UB-8 and U-21 at Istanbul on 4 June. The Russian action forced Ottoman merchant convoys to stay under the protection of the Bosporus forts, and coal rationing in Istanbul was once again enforced. ${ }^{434}$

On 10 June while engaged in collier convoy duties, the Midilli encountered the Russian destroyers Derzkiy and Gnevniy off Zonguldak. The Derzkiy was crippled by the opening salvo and had to be salvaged by the Gnevniy. The Midilli was hit seven times with small caliber shells forcing a retreat and did not finish off either Russian ship. The Midilli, like the Yavuz, could not be risked. ${ }^{435}$ Russian battleships were not sortied in June 1915 for fear of German U-boats. The absence of Russian capital ships provided the

${ }^{434}$ Greger, 50 .

${ }^{435}$ Güleryüz, 49. 
Ottomans with an opportunity to resupply, via convoys, the coal for Istanbul. However, because of the Russian sweeps in early 1915, few colliers were available and demand outstripped supply.

On 5 July the German submarine UB-8 became operational for Black Sea sorties. However, Ebergard had marshaled the Black Sea Fleet, and UB-7 found no opportunities for attack and returned to port on 22 July. The UB class submarines were ill equipped for the Black Sea and would find little success during the war.

On 12 July the Midilli departed the Bosporus for Karabuena in order to escort the merchant S.S. Kesan through the minefields. After a half-hour steaming, the cruiser hit a mine laid by the Russians on 21 December 1914 northeast of the entrance. Though flooded with over 642 tons of sea water, the cruiser reached Istiye where it was drydocked and inspected revealing slight seam damage. But because of a shortage of materials and qualified shipyard personnel, the cruiser was laid up until February $1916 .{ }^{436}$ In July the Russians began deploying destroyers and torpedo boats out of Batum in order to increase their sea presence along the Anatolian coast. The move was successful, and the Russians sank over 150 small sailing vessels in less than six days. ${ }^{437}$ The numerous sailing vessels plying the Black Sea indicated an almost complete absence of large-bulk transports. But the economic demand for goods transported via waterway had grown to a level that rewards outweighed risk. The demand for shipping permits,

${ }^{436}$ Corbett, Naval Operations, Vol. III, 79.

${ }^{437}$ Emin, 138-139. 
necessary in order to conduct any mercantile enterprise, had been a catalyst for inflation. Public discontent resulted in the creation of a "Supreme Food Commission" in 1918 to regulate the marketing of shipping permits and reduce black-marketing.

On 3 August the Ottomans organized a convoy consisting of the Muavent-i Milliye, Numune-i Hamiyet, Tasoz, and Hamidiye, and the large colliers Eresos, Illiria, the Seyhun, and the Zonguldak. On the return leg of the convoy, the Russian submarine Tjulen torpedoed and sank the Zonguldak near Kefken Ada. ${ }^{438}$ From 29 August to 3 September, the Ottomans lost 319 sailing vessels along the eastern Anatolian coast. The destruction of the last Black Sea large colliers occurred on 5 September. Two large Russian destroyers, along with the submarine Neepa, attacked a convoy consisting of the Eresos, the Illiria, and the Seyhun, protected by Numune-i Hamiyet, Hamidiye, and the Muavent-i Milliye. The Hamidiye closed with the Russians, and in the course of the fight both of Hamidiye's $15 \mathrm{~cm}$ guns were put out of action. The cruiser was forced to withdraw, and the colliers scattered. The Russians forced the colliers aground at the estuary of the Sakarya River and systematically destroyed all three plus the Ottoman tug M.V. Seyyar. ${ }^{439}$

German naval planners began operating U-boats covertly out of Varna, Bulgaria in late September, Varna was better suited for U-boat operations because of a direct rail link to Germany. Based was at Eurinograd, the UC-13 had been covertly operating from

${ }^{438}$ Güleryüz, 49.

${ }^{439}$ Greger, 51; Nerasov, 65. 
Bulgaria from 30 September. On 6 September 1915 a treaty of friendship and alliance was signed formalizing the relationship. When Bulgaria entered the war on 6 October, UB-14 began to sortie from Eurinograd with initial success. Between 3 October and 19 October, UB-14 sank the Russian merchants Katja and the Apseron. However success was short-lived. Bulgaria did not possess a fleet capable of defending the coast and thus had to be defended with the meager resources available to Souchon. In order to strengthen the defense of Varna and Eurinograd, Souchon deployed UB-8 and UB-7 in late October. ${ }^{440}$

Bulgaria entering the war did spread the Russian Black Sea fleet. The Bulgarian Navy was Russian-trained, and Istanbul now had a large pool of Russian-speaking officers fully versed in Russian tactics. But Bulgarian ports were figured into Ebergard's Bosporus amphibious operations and Varna and Eurinograd were shelled on 22 October and 27 October ${ }^{441}$ Souchon left the submarines in Bulgarian waters in the hope of luring the Russians back for an ambush. Ebergard did not return until 24 December, and weather conditions prevented the submarines from deploying effectively.

The Russians deployed submarines around the coaling center of Zonguldak, and on 14 November the Yavuz narrowly missed being hit by a torpedo fired by the Russian submarine Morz. The Yavuz was the only Ottoman surface ship capable of defending the colliers, since the Midilli had been mined on 18 July. The Yavuz was also the prime

${ }^{440}$ Greger, $51-52$.

${ }^{44}$ Nekrasov, 65. 
target of any Russian submarine and Souchon removed the battle cruiser from Black Sea operations temporarily on 15 November.

By the end of 1915, the Ottoman navy had lost most of its Black Sea colliers and large transports. Transport of coal now depended on a fleet of small sailing vessels, dhows, tugs, and Bosporus ferries. Along the Anatolian coast, naval operations became increasingly half-hearted. When the Yavuz was damaged on 26 December 1914, conditions were right for the Russian fleet to take full command of the Black Sea without having to wait for the new battleships. The Russians appeared regularly in Ottoman waters, sinking everything in sight. Logistics and weather were the only limitations on Ebergard's fleet until German submarines appeared on September 1915. Prior to the submarines' arrival, the Russians sank a total of 36 merchants and brought in three prizes. After the submarines began operations, only one merchant and two gunboats were lost. But damage had been done to the Ottoman economy. The coal shortage reduced the operational tempo of the Ottoman fleet and the chronic shortage of raw materials now threatened to plunge the Ottoman Empire into a state of chaos.

All the Russian fleets' success could not alter the fact Russia remained severed from the Entente. The Ottoman Black Sea Squadron had held the line and prevented the Russians from reaching the Mediterranean. The failure to break through the Dardanelles resulted in Entente commanders looking at the Black Sea region as a secondary front and resources for war in the theater would become scarce for both sides. 


\section{$\underline{1916}$}

When the Anglo-French forces withdrew from Gallipoli, the Dardanelles transport fleet organized by Usedom became available for transport duties in the Black Sea. But the Yavuz and the repaired Midilli were the only surface combatants capable of convoy duties, because the Hamidiye has experienced engineering difficulties and would not be available to operate until after February 1916. The Russian Caucasus campaign, beginning in February, threatened Trabzon, and Yavuz and Midilli were utilized to ferry troops in order to counter the Russians. The absence of protection for the colliers allowed the Russians to act aggressively, employing seaplanes to attack Zonguldak and damaging the merchant Irmingard. On 12 March Russian destroyers sank the Seyyar. The Russian submarine Morz claimed the Darica on 24 March and the Dubrovnik on 1 April. While the Midilli and the Yavuz were utilized as troop transports from February to June, the Russians destroyed 15,678 tons of irreplaceable merchant shipping. ${ }^{442}$ On 24 April, the Russian submarine Tjulen attacked the merchant paddle-ferry Resanet, towing six barges of coal. The Resanet ran aground and was salvaged later, but the coal barges were destroyed and, as with ships, no replacement was available.

The Russians conducted an amphibious landing and seized Trebizond on 18 April. The Russians moved south towards the British army driving north from the Mesopotamian theater. England may have been Russia's ally, but Petrograd's actions indicate intent to capture Baghdad and securing a waterway to the Persian Gulf. Russia 
had controlled much of Persia; however, diplomatically Petrograd could not force land concessions from Ahmed Shah of Persia (1909-1925). The war against Istanbul provided Russia an opportunity to gain not only the Dardanelles but also the flatlands of the Euphrates River valley. Because the region was sparsely defended, and with the cooperation of non-Turkish Ottoman subjects, the Russians were able to meet up with the British at Kizil Robot in the summer of 1917. But the revolution in Russia prevented any real subjugation of the region.

Souchon went on the offensive in May 1916 when the Midilli laid a minefield off Killia. The mines were delivered by rail from Germany and allowed the Midilli to lay three mine lines off Cape Tarcjamlit and near Sebastopol on 6 May. On 4 July the Yavuz and the Midilli shelled the town of Tuapse, sinking the Russian merchant Knyaz Obolenskiy. The Midilli sank the Russian merchants, Marina Anetta, Rezviy, and Rockliffe. The newly rail line from Germany brought shells for the battle cruisers and allowing the Yavuz to become more active.

The success of the German U-boats and the action of the Yavuz and the Midilli off the Crimea led to a change in command within the Russian navy on 16 July. Vice Admiral Vladimir Kolchak replaced Admiral Ebergard as Commander-in-Chief of the Black Sea Fleet. ${ }^{443}$ The Black Sea had become increasingly important to Russian Army planners, who felt Ebergard had become tired and not up to the task of protecting the 
coastline from Yavus and Midilli. ${ }^{444}$ Kolchak had been an Arctic explorer and had fought with conspicuous gallantry in the Russo-Japanese War. In the years between wars, he had taken part in reorganizing the Russian Admiralty in Petrograd and had been promoted to Rear-Admiral at the unprecedented early age of forty-three and was promoted to ViceAdmiral when assigned to the Black Sea. ${ }^{445}$

The docking of the Yavuz for repairs did not stop the Midilli. On 22 July while en route to mine Novorossiysk, the Midilli engaged the Russian destroyer Schastliviy. However, the Schastliviy communicated via radio with the Imperatritsa Mariya, resulting in the shelling of the Midilli starting from a range of 24 miles. The Midilli was blanketed by shells but escaped by dropping mines in the it's wake. In order to prevent further Ottoman offensive action, from 31 July to 8 August the Russians laid 820 mines in a semicircle north of the Bosporus. All the mines were seeded at night in a systematic manner, not the "throw-and-go" methods utilized earlier. Additionally, two minefields were laid to blockade the sea routes along the Romanian and Anatolian coasts. The mines were seeded close to shore to allow Russian battleships the opportunity for shore bombardment.

The entrance of Romania into the war on 27 August 1916 did little to alter the naval campaign in the Black Sea except remove smuggling from the Romanian part of Constanza. Nevertheless, Ottoman troops from the Bosporus defenses had to be

${ }^{444}$ Nekrasov, 94.

${ }^{445}$ Peter Fleming, The Fate of Admiral Kolchak (New York: Harcourt, Brace \& World, Inc., 1963), 32. 
redeployed to Galicia to prevent an Austrian Army collapse. Russian Naval Intelligence indicated that a determined thrust at the Straits had a high probability of success but the two Russian corps designated for the Bosporus operation had to be redeployed to defend Romania, delaying any amphibious raid near the Straits. ${ }^{446}$

The Russian minefields brought all waterborne coal and food supplies to Istanbul to a halt. In order to counter the mines, the torpedo boats Drac, Samsun, Kutahya, and Yavus and the gunboat Malatya were fitted out as minesweepers. From August to November, five ships including two minesweepers were sunk by mines in and around the Bosporus. ${ }^{447}$

The German submarine force was reinforced in the middle of August by two additional UB boats, UB-42 and UB-45. The submarines took up station outside of Sebastopol, Poti, and Trebizond. On 31 August UB-45 sank the Russian transport Tevere, and on 2 September the transport Gioconda was sunk by UB-45. Both transports were fully loaded with Russian troops taking part in the Caucasus campaign. ${ }^{448}$

Clearing the minefields in order to create a channel, the Ottoman minesweepers swept 157 mines in two days. The Russian naval commanders learned of the sweeping operations, and anticipated collier Patmos sailing instructions by decoding Ottoman radio messages. Kolchak responded by laying 220 mines at various depths west of Kara Burnu and sinking the collier Patmos, along with the minesweeper Malatya. The coal crisis

${ }^{446}$ Nekrasov, 103.

${ }^{447} \mathrm{Ibid}$.

${ }^{448}$ Greger, 57. 
affected the Ottoman fleet, and sailings were sporadic for the remainder of the year. But a three-day storm between 23 and 25 September caused several hundred shallow Russian mines to tear loose and detonated at sea. The nature-made channel allowed shallow drafted dhows and barks an opportunity to make the Zonguldak-Istanbul route in relative safety.

On 2 November, the Russians conducted an amphibious raid on a camouflaged anchorage in the mouth of the Terme. Twenty Ottoman sailing vessels were destroyed by a raiding force of 190 men. This raid was the closest the Russian ground forces would come to Istanbul. ${ }^{449}$ The year ended when the Russian destroyer Pamyat Merkuriya fired on and sank the Ottoman gunboats No. 12 and No. 16 off the Bulgarian port of Rumeli Karaburna. Both gunboats had been pressed into service as minesweepers at Varna and were returning to Istanbul when attacked. ${ }^{450}$

A summary of 1916 finds the naval activity intensifying for the Russians while the Ottomans descended into economic collapse. Istanbul had to have coal to fuel the economy of war, and Russia was intent on curtailing that fuel. The result was constant pressure on the coal facilities at Zonguldak, Camli, and Eregi. The pressure resulted in Ottoman naval assets being utilized not for offensive action but defensive protection of merchant colliers. When military necessity demanded intervention elsewhere, such as in the Caucasus theater or the Crimea, Russian warships sunk irreplaceable colliers at will.

${ }^{449}$ Ibid., 59.

${ }^{450}$ Güleryüz, 52. 
Ottoman warships could not stop the Russian march along the sea at Trabizond. Russian capital ships along with seaplane tenders had complete mastery of the theater. The Russian amphibious landing of 53,000 men in two large scale assaults, with no Ottoman naval presence, is clear evidence of Russian sea control. The strengthening of the German submarine forces did bring some relief for the colliers, and several Russian merchants were lost. But Russian military commanders switched to a massive mining campaign at both the Bosporus and Varna and successfully countered any effect of the German submarines.

Soon after the changing of command of the Russian naval forces, Vice-Admiral Kolchak replaced Admiral Ebergard, the land campaign switched from a military operation to ethnic cleansing. Starting in 1916, almost one million Muslim Turks and Kurds were forced to migrate to western Anatolia. This exodus compounded economic and social problems inherent in "normal" wartime. ${ }^{451}$ There is no evidence that Kolchak instituted ethnic cleansing, but the abuse of non-military Ottoman Muslims occurred in earnest after Kolchak assumed command. As the Russian naval campaign slowed, the ground action accelerated and Russian advances along the Black Sea indicated a strong desire to fulfill the Sazonof-Paleologue agreements of 4 March 1915, in that Istanbul and the Straits were conceded to Russia. Further agreements included the vilayets of Trebizond, Ererum, Van, and Bitlis in the deal. ${ }^{452}$ France and England had failed to

${ }^{45} \mathrm{E} \operatorname{Emin}, 248-294$.

${ }^{452} \mathrm{C}$ opies of agreements can be found in Mears, 611-618. 
deliver the Straits to Russia using massive naval and minimal land power, and Petrograd's actions indicated a desire to utilize sizable naval and land power to secure the Black Sea basin with or without Entente assistance.

\section{$\underline{1917}$}

The year began for Istanbul with four Russian submarines prowling the Bosporus Straits continuously. The Russian submarine Nerpa attacked the merchant Nusret on 7 January. On 12 January the Russian submarine Narval attacked and sank the salvage fleet sent to assist the Nusret, sinking the ferry Neveser, the merchant Moda, and the brig Dervis, along with seven sailing vessels. In order to strangle further the economy, the Russians lay an additional 440 mines in three semi-barriers northeast of the entrance to the Bosporus, and the barriers were laid shallowly, partly between the shore and the existing mines. Whatever channel had been created by the 23 September 1916 storm was now fully blocked, and on 6 February the merchant Neveser hit a mine and sank. ${ }^{453}$

During the early months of 1917, Russian destroyers sank a considerable number of small sailing vessels and dhows, now the sole means of transportation along the coast. Because of weak coastal defenses, the Russian destroyer Derzkiy was able to sail into Sinop on 29 January and destroy seven sailing ships. In March, the Russians shelled Giresum and Tirebolu, and a number of small craft were lost.

The aggressive Russian offensive in eastern Anatolia was in high gear. The refugee crisis overwhelmed Red Crescent operations, and the internal Armenian

${ }^{453}$ Greger, 61. 
insurrection instigated by Petrograd created wholesale slaughter. ${ }^{454}$ Russian naval planners intended on capitalizing on the chaos in eastern Anatolia by an amphibious landing off the Bosporus on 26 March. Three Russian seaplane tenders, Aleksandr, Nikolaj, and Romania, conducted photo reconnaissance of the projected landing sites. On 4 April the three seaplane tenders reconnoitered the Bosporus and seaplanes bombed coastal batteries at Kilgos. In responce to the bombing, seven Ottoman planes flying from Kefken attacked the Russian tenders. Russian uncertainty over air superiority placed the amphibious operation on hold. Additionally, the status of the Yavuz and the Midilli was unknown, and an amphibious assault within range of those two ships was not prudent.

During April and May, Ottoman minesweepers cleared a channel out of the Bosporus and the Russians responded by sending a fleet of small motorboats to re-mine the approaches. The operation was conducted at night without being seen by coastal patrols and the re-mining remained unknown to the Ottomans until 27 May, when a mine self-detonated. On 17 May Germany dispatched six minesweepers to Istanbul by rail. This group, combined with Ottoman assets, managed in two weeks to clear a minefree route. To hamper the work of the minesweepers and to block the route for small craft, the Russians decided to block the Bosporus with small mines of the "Rybka" ("small fish") type, which had a charge of thirty kilograms but which could be carried by small motorboats. The Russians seeded over 800 "small fish" mines in two weeks. Istanbul

${ }^{454}$ For information on the Russian-inspired Armenian uprising, see McCarthy, 192230. 
responded by aerial attack that forced the Russians to attempt night seeding, which proved disastrous. Several minelaying boats were destroyed and future night mining was curtailed. ${ }^{455}$ Russian indecision over amphibious operations and the questionable attempt at night mining, suggest a serious fear of air attacks.

In May the Russian fleet began to operate out of Trabizond, cutting sailing time to Ottoman defensive positions from one day to three hours. The forwardly deployed Russian fleet was vulnerable, with an extended supply and communication lines, but Ottoman fleet units could not take advantage of the situation. On 30 May the Russians entered the harbors at Unye and Ordu and sank whatever vessels were found. The Russian Black Sea Fleet remained aggressive and very active well after the Russian Revolution. Nevertheless, growing friction between Kolchak and the Revolutionaryinspired Central Committee of the Black Sea culminated on 26 May with Kolchak's request to be relieved of command. Kolchak's successor, Vice-Admiral Lukin, attempted to continue Kolchak's policies but politics had begun to influence the Russian crews. ${ }^{456}$ Kolchak resigned his appointment and accepted an invitation from the United States Navy Department to lead a small technical mission to United States. He returning during the chaos of the Revolution and would ultimately become "Supreme Ruler of All Russia." That position placed him in the position of confronting the Bolshevik revolutionaries and would eventually cost him his life. Kolchak was convicted and

${ }^{455}$ Güleryüz, 52.

456Halpern, A Naval History, 252. 
executed for inciting massacres while leader of the White Regime. ${ }^{457}$

On 23 June the Midilli, rearmed with 8-150 mm guns in place of the $12-105 \mathrm{~mm}$ and fitted with mines, sortied to Fidonisi Island. After mining the area and destroying a Russian radio station, the cruiser made for the Bosporus. However, on 25 June the Midilli encountered the Russian battleship Svobodnaya Rossiya (the ex-Imperatritsa Ekaterina) and the destroyer Gnevnity. After exchanging salvos, the Midilli made for Istanbul. This was the last skirmish in the Black Sea between the Russians and German-crewed surface units. ${ }^{458}$

During the months of July and August, Russian surface units shelled small villages along the Anatolian coast. The large towns of Sinope and Tirebolu were repeatedly shelled, though the Ottomans had demilitarized the cities. Although the shelling was characteristically random and suggest no systematic effort to prepare the region for an amphibious landing, Istanbul interpreted the shelling and subsequent commando raids as an indication of a possible full-scale amphibious operation. Ottoman troops were transferred to coastal areas to defend important coastal areas. ${ }^{459}$ On 27 August Russian naval commanders dispatched large destroyers to western Anatolia to reconnoiter the coast in connection with a possible large-scale landing. The destroyers sank nineteen merchant vessels. Ottoman surface units were non-existent because of a complete lack of coal. In addition to small merchant vessels, the Russians destroyed

${ }^{457}$ Fleming, 111.

${ }^{458}$ Greger, 63; Nekrasov, 129.

${ }^{459} \mathrm{Ibid} ., 64$. 
fishing boats plying just outside the Bosporus Strait. On 29 August the Russian Supreme War Council decided to postpone any Bosporus landing and delayed the anticipated Dobrudcha amphibious assault because of the lack of troops and the situation on the Eastern front. Instead of ferrying troops, the ships would be utilized for grain transport from the Kuban region of Novorossiysk to Odessa, since the railroad could not assure delivery. Rail traffic had been disrupted by revolutionary action from Bolshevik cells within the Russian army, and from Ottoman commandos disembarked via German submarines. ${ }^{460}$

Souchon was relieved of duties on 4 September 1917 and returned to Germany to assume command of the Fourth Squadron of the High Sea Fleet. Souchon's replacement was Vice-Admiral Hubert von Rebeur-Paschwitz. ${ }^{461}$

Russian destroyers operated along the Anatolian coast west to Constanza and swept the coast of all merchants. From 30 September to 24 October, 23 Ottoman merchants were sunk or run aground. Fearing the route to Constanza was mined, Istanbul deployed the gunboat Hamidabad, towing three small German-built minesweepers to the forward-theater base at Igneada. En route, the Russian destroyers Py/Kiy and Bystriy intercepted the Hamidabad, and the gunboat was set ablaze. The minesweepers escaped when the craft were released to flee. Istanbul deployed the Midilli to hunt the Russians, but the destroyers fled north to safety. The Russian Black Sea commander, Rear Admiral

${ }^{460}$ Greger, 62. See also Halpern, A Naval History, 244.

${ }^{461}$ Halpern, A Naval History, 255. 
Nemitc, having relieved Vice-Admiral Lukin, ordered the Russian fleet to intercept the Midilli. But the crew of the battleship Svobodnaja Rossija refused to pursue and returned to Sebastopol. On 8 November Nemitc ordered all units of the Black Sea Fleet to obey only orders from the Central Committee of the Black Sea. The Russian Black Sea Fleet did not conduct any offensive action for the remainder of the war. ${ }^{462}$

With Russia imploding and the Russian fleet dockside, the Midilli showed the flag along the Anatolian coast. Mines were an ongoing problem, but with the threat of offensive action from Russia removed, coal shipments resumed. An armistice was concluded between Germany and Russia on 16 December 1917. Although the threat to merchant shipping was gone, and the Russian army was in retreat, the Ottoman navy had little to celebrate. The Ottoman fleet was worn out, and every ship needed refitting. But the morale of the crews remained high, even when Russian surface action forced Istanbul to marshal the fleet within the Bosporus. The three years of action had raised public opinion of the navy, and the level of training had done much to improve the fighting spirit of the Turkish seamen.

In summary, 1917 began with the Russians in command of the Black Sea. The massive mine barrage, along with the merciless destruction of Ottoman merchant ships, paralyzed Istanbul and crippled the Ottoman economy. Prior to the replacement of Vice-Admiral Kolchak by Rear Admiral Lukin, preparations for a large scale amphibious landing off Sinope and later around the Bosporus almost became reality. The coast had 
been reconnoitered, and ships, troops and supplies assembled in the Crimea. The internal Russian political fallout from the February Revolution was not felt in the Black Sea until June, and the initial change was only the replacement of Kolchak by Lukin. The Russian desire to acquire the Bosporus was still strong until an attempt to land Russian troops at Varna on 27 August. The Ottoman mobile defenses, developed and refined in the Dardanelles campaign, proved too formidable. The prospect of amphibious landing in Anatolia and running the risk of even more virulent defenses seems to have influenced the Russian Supreme War Council.

The Russian offensive against the colliers had serious repercussions on the coalfueled Ottoman Fleet. Lack of coal prevented much of the fleet from large scaledeployment. The need to supply the two most capable ships, Yavuz and the Midilli, caused diminished steaming time for other less capable units. The minesweeping operations along the Anatolian coast were an example of the determination of Ottoman crews in the face of overwhelming Russian superiority. The Ottoman use of airplanes to torment Russian minelayers and submarines prevented complete closure of the Bosporus and possible capitulation due to economic prostration. The Ottomans may not have won every skirmish, but the Sultan's fleet was intact and still active at the end of 1917.

\section{$\underline{1918}$}

Russia was forced into peace and Romania defeated by Falkenhayn, Istanbul once again found the Black Sea peaceful. But lack of warfare did not equate to slack time for the Ottoman fleet. On 20 January, the Yavuz, Midilli, Samsun, Muavent-i Milliye, Numune-i Hamiyet, and Basra sortied out of the Dardanelles and caught the Entente by 
surprise. The Ottoman naval commander, Rebeur-Paschwitz, wanted to demonstrate to the Allies that the Entente dreadnoughts that were shelling the Ottoman armies in Palestine needed instead to guard the Dardanelles.

Rebeur-Paschwitz planned on a surface raid on the British-occupied Greek port of Salonika. British reinforcements for General Allenby were being assembled at Salonika, and a Ottoman surface attack could prevent Allenby from following up on the Palestine campaign. Additionally, a surface attack would restore morale within the Ottoman ranks. Before the operation could commence, altered the operational objectives to the destruction of British observation forces off the Dardanelles. Rebeur-Paschwitz feared that a surface raid on Salonika would allow superior Entente forces the opportunity to block access back to the Dardanelles. A successful sortie by Yavuz could draw Entente forces back to the Straits, where the German submarine UC 23 would seed mines and lie in wait for a target. ${ }^{463}$

On 20 December 1917, a British armed steamer ran aground by the Gulf of Saros. Ottoman troops boarded the craft and found among the ship's papers a chart of the Dardanelles showing dark lines in the channel. Ottoman Fifth Army Commander, General Liman von Sanders, passed the information onto Rebeur-Paschwitz who interpreted the lines to indicate mines and thus ignored his charts compiled via air reconnaissance that showed a clear channel. 
The Admiral pressed ahead using the captured charts and the Yavuz struck a mine on the port side. The damage, buffeted by an armored skirt and coal bunkers, did little damage and flooding was contained. The sortie continued and soon the Ottoman warships opened fire on the British monitors H.M.S. Raglan and M-28, anchored at Kusa Bay, Imbros. The Midilli's fire was excellent, and soon both monitors were sunk. The ships continued southwest of Imbros, where the Midilli was mined which destroyed the steering gear. Yavuz, turning to assist Midilli was mined at the stern. As the Midilli drifted, two more mines exploded on the port side of the cruiser. Several minutes later, another mine exploded under the bow. A fifth mine detonated under the bridge, and Captain Hippel ordered the ship abandoned. Only half of the 500-man crew survived to abandon ship, and only 140 were rescued. ${ }^{464}$

The Basra, Muavent-i Milliye, Amsun, and Numune-i Hamiyet rushed to assist the Midilli. At the same time, British destroyers HMS Lizard and HMS Tigress rushed to the area in order to engage the Ottoman warships. The Yavuz, in an attempt to assist Middilli, struck another mine amidships, port side. Captain Stoelzel, Yavuz's command officer, decided to return to the Straits once the Midilli sank and rescue was hopeless. With a pilot on board to assist in the Dardanelles channel, Yavuz struck a third mine amidships, starboard side. The flooding from the starboard blast corrected the list created from the two previous port explosions. The battle cruiser had experienced three mine detonations but still maintain fourteen knots entering into the channel. 
As the warship maneuvered close to the Asiatic shore off Nagara to avoid minefields, Yavuz plowed into the sand bank, burying one-third of its keel into the sea bed. Stoelzel attempted to counterflood the aft compartment, shift coal and ammunition, and jettison unneeded material to lighten the ship, all to no avail. Stoelzel ordered all secret documents destroyed and began to remove the crew and all supplies on the assumption the Entente would destroy the warship with indirect fire using planes for spotting. The British attempted the first offensive air attack upon a warship from 21 through 26 January, with little success. The British Admiral, Arthur Hayes-Sadler, failed to follow up on the attack, believing the Yavuz was still too powerful to attack. Admiral Usedom, commanding the defenses of the Dardanelles, began to salvage the Yavuz on 21 January. Usedom believed indirect fire would be ineffective and the largest ordnance available to the Entente for air delivery, 230 pounds, unlikely to do considerable damage. Stoelzel returned the crew to the ship and continued the lightening process. To protect the Yavuz, Usedom brought in eight shore anti-aircraft batteries and kept any Entente warship beyond gunfire range by using shore artillery. ${ }^{465}$ The salvage operation consisted of lightening and ballast shifting in the belief that the warship would pull itself out of the sand. On 26 January, with Torgud Reis tied fast along the starboard side and pulled the Yavuz free. ${ }^{466}$

${ }^{465}$ Ibid., 229.

${ }^{466}$ Henry Newbolt, Naval Operations, Vol. V (New York: Longman's, Green and Co., 1931), 88-91. 
The vacuum created by the Russian Revolution left vast areas open to occupation, not only in eastern Anatolia, and the lower Caucasus region. Ottoman naval operations in January and February consisted of ferrying German troops to Giresun and Odessa from Constanza and Varna. Ottoman army units were also transported to Trabzon in order to secure the region and protect the Muslim population from retreating guerrilla attacks. Ottoman control of the Black Sea jeopardized the British position in Persia. Ottoman forces quickly occupied both Persian and Russian Azerbaijan and Persian notables and clerics became openly anti-British. ${ }^{467}$

On 30 March Ottoman naval units resumed patrols with instructions to attack any Russian surface combatants encountered. Counter-Revolutionary forces within the Russian military advocated resumption of the war instead of accepting the Brest-Litovsk Treaty of 3 March, but confusion within the Russian military prevented any armed resistance. On 2 May the Yavuz and the Hamidiye entered Sebastopol and found the port already in German hands. The Brest-Litovsk treaty required Russia to relinquish it's fleet and bases to Alliance forces. The Ottomans took advantage of the dry-docking facilities and repair yard. The hull was scraped down and the mine damage inflicted in January off the Dardanelles was repaired. The Russian cruiser Prut, the former Mecidiye, was recovered in a poor state. Once seaworthy, the cruiser was towed to Istanbul by the Hamidiye and arrived on 13 July. ${ }^{468}$

${ }^{467}$ F.J. Moberly, Operations in Persia, 1914-1919 (London: Her Majesty's Stationary Office, 1987), 321-322.

${ }^{468}$ Güleryüz, 54. 
The threat from the Russians reappeared on 28 June when Bolshevik cells in Novorossiysk refused to intern the Russian Black Sea fleet, as required by the treat of Brest-Litovsk. The Yavuz, Samsun, Numune-i Hamidiyet, and Muavent-i Milliye were dispatched to Novorossiysk to force the internment of the Russian warships still in port. On arrival, the Ottomans found the Russians had scuttled the ships. The Yavuz returned to Istanbul and was laid up at Istinye until the end of the war.

With the naval war in the Black Sea ended and the Dardanelles sealed by Entente forces, the Ottoman fleet was reorganized with the Hamidiye as flagship. The torpedo boats Akhisar, Drac Musul, and Sultanhisar remained on active duty. The Berk-i Satvek and the Peyk-i Sevket remained on patrol in the Black Sea off the Crimea, and the Burak Reis, Isa Reis, and Sakiz cruised between Zonguldak and Batum. ${ }^{469}$

On 14 July Ottoman naval commander Rebeur-Paschwitz received only the destroyer R-10 and four tugs from the interned Russian Black Sea fleet. The Germans feared that the Brest-Litovsk Treaty did not allow for the transfer of warships without monetary compensation. The Ottoman navy would later receive a mixed group of small naval craft and auxiliaries which were neither commissioned into the fleet nor entered naval service. The Ottomans had good reason to believe a large portion of the Russian fleet might end up under Istanbul's control. A secret letter from the German Foreign Secretary about the treaty stipulated that the Alliance should be given the Russian warships for "peaceful aims," such as minesweeping and police service. In case of war 
necessity, the warships might be used for military purposes with full compensation for losses. Since this agreement dealt with only German crews, the Germans planned to have the ships manned with a nucleus of Germans with a large Ottoman crew for "training." The German plan was to bring the two pre-dreadnoughts, the Evstafi and the Zlatovst, to Istanbul for defense of the Dardanelles. The idea was abandoned when Ottoman commanders realized there were not enough trained sailors left after the Germans placed the Russian dreadnought Valga in service. ${ }^{470}$

The ruling political party of the Ottoman Empire was the Committee of Union and Progress. Popular unrest from economic mismanagement fostered disagreement among the C.U.P. and the ruling triumvirate, Enver, Djemal, and Talaat, resigned 7 October 1918. A new cabinet under Izzet Pasha opted to sue for peace rather than pursue the war. Grand Vizier Izzet Pasha immediately sought peace with the British. However, a draft naval armistice had been prepared by 7 October 1918, the same day Izzet assumed power. The timing suggest prior discussions. The first draft naval armistice dealt with economic more than military subjects, of the nineteen clauses, ten addressed logistic or revenue producing subjects. In the second draft, dated 22 October, of the 24 clauses, seven dealt with economic or revenue producing subjects. The final document, agreed upon and signed on 30 October, consisted of 25 clauses; twelve dealt with economic or revenue producing functions. ${ }^{471}$

${ }^{470}$ Halpern, A Naval History, 258.

${ }^{471}$ A copy of naval armistices is found in Newbolt, Naval Operations, Vol. V, 418422. 
Armistice dicussions were held aboard the HMS Agamemnon and an agreement was signed on 30 October. ${ }^{472}$ The Porte concluded an agreement with the British Admiral Calthorpe who excluded the French Admiral Amet from negotiations for two reasons: the Ottoman negotiators were only accredited to negotiate with the British; and the diplomatic maneuvering over the spoils of the war had begun. ${ }^{473}$ The armistice called for all repatriation of Allied prisoners, demobilization of the armed forces, and severance of diplomatic ties with the Central Powers. The Ottoman navy would be interned at Istanbul and Izmir and turned over to the Allies. The new Naval Minister, Rauf Pasha, disbanded staff and ship crews. However, minesweeping units would continue sweeping the barrages and minefields in order to allow safe passage for Allied warships. The Allied warships entered Istanbul on 13 November 1918. With her German crew repatriated to Germany, the Yavuz was towed away and allowed to settle into the mud off of Istanbul. The Porte refused to allow the English to salvage the warship or remove Yavuz from Ottoman territory. ${ }^{474}$

In summary, 1918 witnessed the Ottoman Fleet re-emerging as a force in the Black Sea. With the Russian Revolution spreading to Sebastopol and Novorossiysk, the only force capable of restraining Bolshevik sailors was the disciplined Ottoman fleet.

${ }^{472}$ Halpern, The Royal Navy in the Mediterranean 1915-1915, 361.

${ }^{473}$ HMS Agamemnon was named after a Greek Admiral who sacrificed his daughter to ensure victory at Troy. The daughter's mother, Agamemnon's wife, executed the Admiral to avenge her daughter. Agamnmnon's son Orestes, kill his mother to advenge his father, who killed his sister. The armistice agreed upon on 30 October would lead to such intercommunal killing when Greek troops were allowed to land in Anatolia.

${ }^{474}$ Van der Vat, 231. 
The unstable political situation in the lower Caucasus region did allow for injection of Ottoman ground units into Batum, Rize, and Sukhum Kale. But the economic damage inflected by the Russians, and almost seven years of warfare, left the Ottoman Empire prostrated. The Ottoman navy still possessed the discipline to conduct naval operations in a professional manner right up to the armistice at Mudros. Coal supplies from Zonguldak had resumed to an extent that fuel for the fleet was not a grave concern. Nevertheless, armament logistics, shells, powder, mines, and small-arms ammunition had become scarce. The resources necessary to conduct offensive operations had been depleted, nevertheless the fighting spirit of the fleet remained and the crew's esprit de corps resulted in few desertions.

The operations of the Ottoman fleet in the Black Sea were very intense. Russia possessed a fleet capable of strangling the Anatolian coast, and the technical expertise to conduct amphibious operations sufficient to defeat the Ottomans had Istanbul not had some sort of professional fleet. Ottoman naval units did prevent total collapse at the hands of Ebergard's destroyers and minesweepers. Russian battleships did not achieve battlespace dominance as envisioned by Mahan's theory on sea warfare, and neither did the Ottoman's Yavuz. The Black Sea action clearly showed the theater was dominated by small vessels: destroyers, gunboats, torpedo boats, and submarines. With these assets, Ebergard targeted the only facet open to attack: seagoing commerce. Table 32 lists the Ottoman ship losses in the Black Sea.

The loss of merchant shipping capable of ferrying coal had a negative effect on the economy and subsequently the war effort. The Ottoman coal regions around 
TABLE 32

OTTOMAN SHIP LOSSES IN THE BLACK SEA

\begin{tabular}{lll}
$1914 \quad 1915 \quad 1916 \quad 1917$ \\
\hline
\end{tabular}

Merchant

Warship

$\begin{array}{rrrr}7 & 44 & 23 & 11 \\ 2 & 11 & 12 & 3\end{array}$

Source: René Greger, The Russian Fleet, 1916-1917 (London: Ian Allan Ltd., 1972), $67-$ 68.

Zonguldak and Eregli became prime areas for Russian warships. The destruction of colliers caused a drastic reduction in coal production. Table 33 shows coal production from 1913 to 1918.

TABLE 33

OTTOMAN COAL PRODUCTION, 1913-1918

$\begin{array}{cccccc}1913 & 1914 & 1915 & 1916 & 1917 & 1918 \\ 826,000 & 651,240 & 420,317 & 408,203 & 146,000 & 186,000\end{array}$

Source: Ahmed Emin, Turkey in the World War (New Haven, CT: Yale University Press, 1930), 117-118.

Using 1913 as a base, the Ottoman economy witnessed a reduction in coal production of 22 percent in 1914, 49 percent in 1915, 51 percent in 1916, and 87 percent in 1917. The decrease experienced in 1917 was because of the destruction of the loading apparatus in the harbor of Zonguldak by the Russian fleet. The increase witnessed in 1918 reflects the collapse of Russia rather than a change in Ottoman strategy. 
Russian attacks on the coal traffic had the intended results: economic hardships and a reduction in Ottoman ship deployments. Nonetheless, had the ruling junta not been as negligent, the shortages could have been controlled. Souchon repeatedly had to struggle with the Russians and with Enver's careless approach to the coal situation. Enver had not restricted the use of coal by private firms and somewhat naively believed the fleet could protect the colliers. Souchon noted the Yavuz could burn as much coal guarding the colliers as the colliers could load. ${ }^{475}$

As the fuel shortages became more apparent, coal from Germany provided the minimum 400 tons a day for economic activity. The Germans therefore provided roughly 12,000 tons of the estimated 30,000 tons of Ottoman coal consumption in order to keep railway and munitions factories open. ${ }^{476}$ German coal, and whatever coal made the trip from Zonguldak was supplemented by poor-quality coal found around Istanbul and Rodosto. Plans for a railway east to the Eregli coal fields never materialized. Prior to the war, any railway east had to have Russian approval, and St. Petersburg refused. Enver's government believed the war would not last the year that it would take to build the line, and thus considered it unprofitable. Enver's negligence prevented the construction of the one rail line Istanbul had to have in order to survive economically. ${ }^{477}$

The Ottoman Black Sea Squadron did have successes against a numerically superior Russian force. Table 34 lists the Russian ship losses in the Black Sea. The loss

${ }^{475}$ Paul Halpern, A Naval History, 233.

${ }^{476} \mathrm{Ibid} ., 238$.

${ }^{477} \mathrm{Emin}, 86-87,107$. 


\section{TABLE 34}

\section{RUSSIAN SHIP LOSSES IN THE BLACK SEA}

\begin{tabular}{llll}
1914 & 1915 & 1916 & 1917 \\
\hline
\end{tabular}

$\begin{array}{rrrrr}\text { Merchant } & 0 & 5 & 14 & 3 \\ \text { Warships } & 3 & 0 & 6 & 7\end{array}$

Source: René Greger, The Russian Fleet, 1916-1917 (London: Ian Allan Ltd., 1972), 6667.

of Russian merchant shipping was not as problematic for Ebergard as for Souchon. The Russians had a rail and road system capable of transporting wartime logistic requirements, and seaborne commerce was not necessary for war operations.

The Ottoman fleet did not possess the resources to prosecute the war. With the exception of the Yavuz and the Midilli, Ottoman warships were not capable of dueling with the Russians. The British inspired quest for dreadnoughts left no funds for small boats, which wartime experience had shown were the real determiner for success. Additionally, the infrastructure of the Ottoman Empire did not allow for rapid repair or construction of wartime losses. Finally, the personnel reduction started by British Admiral Gambel in 1907 removed crews, both officers an enlisted men, to an extent that when the remnants of the Russian Black Sea fleet became available, the manning levels prevented utilization.

The Ottoman fleet had proved itself in combat, and the Allies intended on utilizing the battle-tested fleet. Ottoman action had repeatedly prevented the numerically larger Russian forces from dominating Anatolia, and if Allied intentions of dividing the 
Sultan's domains were to be successful, the warships had to be neutralized. The Treaty of Sevres, signed on 10 August 1920 but not enforceable, would have divided the Ottoman fleet among the victors. To Britain: Yavuz, Hamidiye, Mecidiye, Muavenet-i, Millet, Numene, Tasoz, Basra, and Samsun. To Japan: Turgot Reis. To other powers: Berk-i Efsan, Pelagni Deria, Zuhaf, Peyk-i Sevket, and Nusret. ${ }^{478}$ Allied restrictions on Ottoman warships resulted in the bulk of the surface fleet's being interned under the guns of the Allies at Izmit and Istanbul. In order to combat smuggling, the Aydin Reis and the Preveze were released and assigned to prevent gun-running from Soviet Russia. Turkish nationalist had purchased arms and supplies from Soviet Russia.

Mustafa Kemel covertly utilized the vessels to smuggle arms to nationalist forces resisting Greek aggression and to prevent Allied interference in the gun smuggling, the Aydin Reis and the Preveze were incorporated into the Red Russian navy. The nationalist victory over Greek forces caused the new Treaty of Lausanne, signed on 24 July 1923, which allowed Turkey to keep the fleet. However, economics prevented funds from being available for repairing or acquisition. 


\section{CHAPTER IX}

\section{CONCLUSION}

The Ottoman navy entered the Twentieth Century lagging behind comparable navies. Istanbul would spend a considerable sum of money trying to keep pace in a naval arms race that would climax in the Nine Power Treaty of 1922 and the London Treaty of 1930. ${ }^{479}$ Nevertheless, an overextended, underfunded, badly balanced Ottoman navy was able to hold off two of the largest amphibious assaults prior to Normandy, at Gallipoli and Rize; execute the first successful sinking of a battleship by a destroyer; confront the first carrier/battleship task force; and experience the first air launched torpedo attack along with equaling the considerably more superior Entente sea fleet.

The circumstances that led to the anemic condition of the Ottoman navy can be found in three sources: political intrigue, the British naval mission, and the Ottomans' ignorance of their own naval needs. Ottoman political leaders did not view the Ministry of Marine as a desirable position. This resulted in twenty-one leadership changes between 1900-1919, as shown in Table 35. Factoring in the lead time in warship purchase and fabrication, most ministers did not enjoyed a fleet comprised of ships ordered during his tenure. Each minister was forced to utilize fleet units ordered by political rivals. The exception was Ahmed Djemal Pasha.

${ }^{479}$ Costello, 40, 44-45. 


\section{TABLE 35}

\section{OTTOMAN NAVAL MINISTERS, 1900-1919}

Name

Celal Bey

Hasan Rami Pasha

Arif Hikmet Pasha

Huseyin Husnu Pasha

Topcu Ferik'i Ryza Pasha

Miriliva Emin Pasha

Emin Pasha

Arif Hikmet Pasha

Ferik Halil Pasha

Sadrazam Hakki Pasha

Mahmut Muhtar Pasha

Salih Pasha

Mahmut Muhtar Pasha

Topcu Ferik'i Hursid Pasha

Curuksulu Mahmut Pasha

Ahmed Djemel Pasha

Rauf Bey

Topcu Ali Riza Pasha

Sakir Pasha

Ahmet Avni Pasha

Salih Hulusi Pasha
End of Duty

1901

1904

July 1906

January 1907

March 1907

April 1907

May 1907

June 1907

January 1908

March 1910

May 1910

November 1910

May 1911

October 1911

July 1912

February 1913

November 1918

December 1918

March 1919

April 1919

September 1919

Source: Muhlis Ergin, Curator, Turkish Naval Museum, Istanbul, to author, 23 October 1997.

Djemal exploited the public's positive view of the navy. As a result the Ottoman Navy became a minor restraint on War Minister Enver Pasha's plans. Grand Vizier Said Halim appointed Enver Minister of War in January 1914. This appointment was without C.U.P. approval or the Sultan's. The Grand Vizier seems to have believed Enver could be controlled if appointed to the government. Djemal Pasha, and Interior Minister Talaat 
Pasha, did not fully support Enver's policies and did counterbalance the War Minister's grandiose plans.

Enver's hold on the Ottoman Army was questionable at best, and the Navy was fully out of step with his plans. As long as the Navy continued to elude his control, Enver could not act and thus would not get truly adequate funding. The Austrian Ambassador, Marquis Johann von Pallavicini, reported that certain naval officers had formed a "ligue militaire" and approached Russia for subsidies and aid to bring down Enver and the Committee of Union and Progress. But Russia's designs on Anatolia prevented any real assistance, and Pallavicini's suggestion that Austria might be willing to assist in arming the Navy went nowhere. ${ }^{480}$ Pallavicini did confronted the Grand Vizier over rumors of Enver's designs on Macedonia and Albania. The Grand Vizier insisted the army and navy were barely strong enough to keep order in the provinces. Nevertheless, fear Enver might attempt to retake lost European provinces concerned Austria. . The Grand Vizier was not above palace politics and looked into replacing German drill instructors with Italian officers in order to lessen German influence. Austria and Italy shared a tense border on the Adriatic, and to have Italians staffing an Army influenced by Enver's imperialistic designs on upsetting the status quo in the Balkans was of great concern for Vienna.

The Ottoman Navy also played a major role in diplomatic intrigue. The Grand Vizier was reported to have approached Italy about supplying arms and ammunition at 
favorable prices in return for certain economic concessions. ${ }^{481}$ Said Halim is also reported to have agreed to place warship orders with Italy. This would explain the Italian contract for four Italian Impavido-class destroyers. ${ }^{482}$ The Austrian Foreign Minister, Count Leopold von Berchtold, reported that the Ottoman Navy was talking with the Japanese, who had seized on the suggestion that their officers might staff the Navy. The Porte did not encourage Japanese hopes of turning an agreement, but Tokyo nevertheless remained willing to help. ${ }^{483}$ The fear of antagonizing Russia by injecting Japanese into the Levant so soon after the disastrous Russo/Japanese War may have cooled any such plans. Japan was a rival of not only Russia, but Germany and France. Tokyo viewed China as a legitimate sphere of expansion, and such plans included European possessions there.

Djemal was not opposed to war in general but was not prepared to commence operations in November 1914. At a cabinet meeting on 12 October 1914, the cabinet agreed to accelerate mobilization and allow Admiral Souchon the Black Sea excursion that might trigger intervention into the war. Djemal noted that the Entente considered the Goeben and Breslau German ships, regardless of the flag and the only Entente member at risk would be Russia, and thus a quasi-peace with England and France could be maintained. The release of the Goeben and Breslau was at Enver's insistence, not

${ }^{481}$ Ibid., 42

${ }^{482}$ Gardiner, 392.

${ }^{483}$ The New York Times, 11 April 1907. 
Djemal's. ${ }^{484}$ Djemal did not have a favorable impressions of Souchon or German military assistance.

Admiral Souchon commenced the Ottoman fleet deployment on 27 October 1914 in order to give the Russians an opportunity to attack the Ottoman fleet and thus be labeled the aggressor. In the event the Russian Admiral Ebergard did not attack first, Souchon was to use his own initiative but Djemal clearly stated the desire not to become involved in the war. Souchon reported that the Ottoman fleet was attacked and in retaliation shelled Sevastopol. A scenario Djemal clearly believed. The Grand Vizier Said Halim questioned the report and in an attempt to maintain peace, proposed an inquiry in order to ascertain the facts and punish the officer in charge. The Entente rejected this suggestion, and the Ottomans found themselves at war. ${ }^{485}$

Enver Pasha had to contend with the Grand Vizier, the Egyptian Prince Said Halim, and the Sultan Mehmet V, both opposed to Enver's egocentric manner. Djemal was not influenced by German intrigue and questioned Enver's schemes. In order to remove Djemal as an obstacle, Enver offered him command of the Ottoman Fourth Army in Syria. Djemal accepted and departed Istanbul on 21 November 1914, leaving the fate of the navy with the War Minister, Enver.

The British naval mission's only purpose were to benefit London and to funnel naval contracts to English shipyards. Any training, advice, or suggestions it provided

${ }^{484} \mathrm{Ahmed}$ Djemal, Memories of a Turkish Statesman 1913-1919 (London: Hutchinson and Co., 1920), 130-131.

${ }^{485} \mathrm{Ibid}$. 
were construed to benefit English concerns. ${ }^{486}$ Ottoman naval leaders possessed little knowledge of naval planning. The exception was Admiral Mahmut Muhtar of the Young Turks movement. He distrusted British insistence upon using English-only yards he favored smaller ships indigenously built. Had Muhtar's views on the fleet been espoused in 1900 and not 1910, the Ottoman defeats in the Italian and Balkan wars may not have happened. In both conflicts, the larger ships of the Ottoman navy, the ships the British insisted the Ottomans needed, went underused because they were too valuable an asset to risk losing. This fear turned the battleships into liabilities. The destroyers and torpedo boats, the lesser assets, had to carry the bulk of the fight to the Greeks and Italians.

British views of Ottoman maritime security had been influenced by the actions of Germany. German battleships had become superior to British-designed ships, and the naval race in Northern Europe altered London's views on the Mediterranean. In order to compete with Germany's growing naval strength, Britain considered removing the English fleet from the Mediterranean back to home waters. Withdrawal of the fleet from the eastern Mediterranean could lead to a loss of influence in Istanbul at the same time that Berlin was gaining favor; and it might induce the Ottoman Empire to join the Triple Alliance as a means of securing support against Russia and reconfirming the Sultan's borders. Diminishing the British fleet could lead to security concerns over Egypt and question the status quo for Cyprus and Crete. British concerns for English possessions in the Mediterranean basin could be eased if France would agree to supply the bulk of the 
French fleet for control of the Mediterranean. However, in the case of a continental war involving all the Triple Alliance-Germany, Austria-Hungary, and Italy-French naval forces would be tasked to defend against the Italian fleet as well as to ferry Algerian troops to France, leaving few if any forces to assist in the protection of English possessions.

Sir Edward Grey, the British Foreign Secretary, feared that Britain could not hold Egypt if command of the Mediterranean were lost and he solicited Egypt's Lord Kitchner's views while at a meeting at Malta on 8 May 1912. ${ }^{487}$ Kitchner did not believe that he could hold the Egyptian Mediterranean coast without the English fleet. He envisioned falling back into the desert as the Ottomans had done in the Tripolitanian conflict and waiting until reinforcements from India arrived through the secure Red Sea region. British concerns for Egypt could be mitigated if Italy were exhausted in Tripolitania and Cyrenaica and if the Ottoman navy were unable to conduct amphibious operations along the Mediterranean coast or the Suez Canal. ${ }^{488}$

Kitchner estimated that if the Ottomans joined in with the Triple Alliance, the bulk of Istanbul's forces could march overland from Syria into Egypt. Preventing the transiting of troops across the Suez Canal could be accomplished with the few gunboats presently on station. Kitchner was concerned with the possible landing of Ottoman troops at Alexandria and Tinch Tay, to the east of Port Said. To prevent such landings,

${ }^{487}$ N.O. 387, Sir E. Grey to Lord Kitchner, Malta, 8 May 1914. Found in Gooch, Vol. X, Part I, 590.

${ }^{488}$ Halpern, The Mediterranean Naval Situation, 21-23. 
Kitchner needed the British fleet to stay in the eastern Mediterranean, which was not possible due to public demands for protection in England's home waters. British influencing the material direction of Istanbul's navy could prevent the Ottomans from landing troops by sea. A fleet expending limited funds on capital ships would not have resources to spend on amphibious or troop transport vessels.

The personnel reduction put in place by Admiral Gamble reveals that, while the Ottomans were reducing, all potential enemies were increasing manning levels. Russia was increasing personnel and material for the Black Sea fleet, and Greece was purchasing battleships from the United States and ordering one each from Germany and France. Great Britain, which was in a naval race with Germany, increased personnel from 129,000 to 136,000 over a seven-year period. ${ }^{489}$ At the same time, an English Admiral was insisting upon a reduction in force for the Ottoman Navy. Simple mathematics clearly shows that the manning force envisioned by Gamble did not adequately address Ottoman needs. Such a reduction did remove an older officer corps not trained and thus not influenced by English mentors. The reduction in force had the potential to create an impotent navy capable of little more than custom duties and no chance of enforcing the Sultan's suzerain over Cyprus, Egypt, Tripolitania, or Arabia.

The Ottomans used naval programs and tactics drawn up by the British mission. The frenzy of shipbuilding typical of the early Twentieth Century drove naval plans to include large capital ships. The Ottoman ministers responsible for naval matters did not 
seem to realize that the programs the British naval mission proposed were influenced by both Alfred Mahan's view on empire-building and British experience in empire-seizing. In neither scenario is the true problem of the Ottoman Empire confronted: that of empire protecting. The Ottomans were not into empire building or seizing. The Ottomans wanted only to hold onto what was theirs, not antagonize the mainly Christian states that the Ottoman Empire bordered.

Empire maintenance calls for smaller, more numerous warships, which were inexpensive to acquire, maintain, and utilize. Most importantly, they could not be so valuable as to preclude utilization in any situation. Had the Young Turks' views of naval needs been followed--a large number of indigenously produced destroyers and torpedo craft versus the foreign-built capital ships the British espoused--the Ottomans' security needs would have been better served. The use of small craft for coastal defense of distant regions of an empire was not unique. The English pioneered this naval doctrine in the late nineteenth century. The distant dominions of the British Empire were protected by gunboats, destroyers, and cruisers. But the British naval mission promoted a program exactly opposite to what the English themselves utilized with a similar far-flung empire.

Ownership of a capital ship promoted what the Ottomans hoped to avoid: ethnic nationalism and a naval arms race with Christian countries. . The "national honor" of countries such as Greece and Italy dictated acquisition of battleships and dreadnoughts, and the Ottomans became ensnared. The difference between the other countries and the Ottoman Empire was the ability to acquire ships. The Italians had shipyard facilities capable of building such ships. The Ottomans had no facilities capable of producing 
ships larger than a protected cruiser. Even such a modest project presented logistical hurdles such as large caliber armaments fabrication and rolling standard steel plates of thickness of one inch or more. Neither could be accomplished in Ottoman yards. This necessitated acquiring naval assets overseas.

The late British Prime Minister, Sir Winston Churchill wrote in a letter to Turkish President Inönü that "German intrigues and British and Turkish mistakes [that] led to our being on opposites sides. ${ }^{1490}$ German intrigues did play a part in dragging the Ottomans into the war. The German ambassador to the Ottoman court, Baron von Wangenheim, knew his position and served the Kaiser well. However, Wangenheim did not take Cyprus and Egypt from the Ottomans; the English did. The English sided with Greece over Crete, and a British naval mission to Greece orchestrated the interdiction of Ottoman troops during the Balkan Wars that ultimately led to the Ottoman defeat and subsequent slaughter of Muslims. ${ }^{491}$ Finally, the Anglo-Russian Entente of 1907, along with the Anglo-French Entente of 1902, left the Ottomans with no ally to provide sea power to complement Ottoman land forces. When Istanbul found no naval power to complement Ottoman ground forces, it forced spending to acquire a respectable fleet. Economics and political reforms coupled with social engineering did not allow for expansion of both army and navy services. Istanbul opted for army modernization in

${ }^{400}$ Winston Churchill to President Inönü of Turkey, 27 January 1943, transcript found in Winston Churchill, The Hinge of Fate (London: Houghton Mifflin Company, 1950), 616. 
order to protect the populace and deter aggression from lesser powers. To deter dismemberment from Russia, France, Italy or Great Britain required a tangible navy.

The primary mistake made by the Ottoman government was in trusting foreigners in naval matters, especially the British. As for the Germans, total control of Ottoman naval assets did not occur until 9 September 1914, when Admiral Limpus of the British naval mission withdrew. Germany's Wangenheim intended on controlling enough of the Ottoman military to prevent Istanbul from copying Rome and ignoring treaty obligations. Limpus' leaving made Wangenheim's task easier. With Limpus gone, the Porte had no choice but to utilize the services of Souchon. He was not an ideal candidate for the Ottoman Navy, having a reputation of poor training and sloppy discipline and Souchon did nothing to indicate he considered himself seriously subordinate to Ottoman oversight or accountability.

Non-military sealift is one where modern military planners place heavy emphasis. The use of commercial vessels to support the needs of the state is vital. S.G. Gorshkov, former Admiral of the Fleet for the Soviet Union, states, ". . among the main components which we [the USSR \} include in the concept of the sea power of the state are the state's capabilities to study and exploit its resources, the condition of the transport and fishing fleet and its ability to support the needs of the state." ${ }^{1422}$ Both the British and Germans, when preparing plans for the Ottoman navy, left out non-military sealift. This might have been oversight, for both England and Germany had commercial shipping in (Washington, DC: US Government Printing Office, 1985), 73. 
such numbers that fleet support was never in question. However, neither England nor Germany had fought a conflict such as the Balkan Wars where the outcome was decided entirely on the inability of one side to transport troops a short distance.

The Ottoman merchant marine was significantly smaller then those of Greece and Russia. The lack of a sizable merchant fleet consisting of general or break-bulk cargo ships forced the Ottoman mercantile to rely on foreign ships to carry freight and passengers. The barrier to creating a viable merchant marine tended to lie with the economic capitulations the Ottomans were forced to contend with. These economic agreements stifled indigenous merchant shipbuilding. The British naval mission's prime directive was to look after British interests, and British bottoms carried a sizable share of the capitulation trade. Had the Ottomans dispensed with the capitulations and created a merchant marine capable of servicing the needs of the empire, the English shippers would have been the losers.

The failure of Ottoman commercial vessels to deliver troops from Asia to the European theater during the First Balkan War cost Istanbul the war. Admiral Usedom, when confronted with this predicament, brought Austrian ferries in and requisitioned every available craft. Had the Young Turks movement successfully pursued economic self-sufficiency, commercial vessels may have been available in greater numbers. Compounding the sealift shortage was Enver's ill-advised Caucasus Campaign. Ottoman merchant shipping tonnage was 250,000 in 1914. By 1916, 102,786, or 41 percent, had been lost as a direct result of supporting the offense in the Caucasus Region. Even with the seizure of Entente merchant shipping trapped in Ottoman waters, the lost tonnage 
could not be replaced. For any nation that relied extensively on waterborne commerce such as the Ottoman Empire did, loss of 41 percent could be managed if replacement were possible or alternative delivery methods utilized. In the Ottoman theater, replacement was impossible, and alternative delivery impracticable. The merchant shipping tonnage cited for 1914 was that for all of the Ottoman Empire. Merchant ships outside of the Dardanelles were prevented from entering the Straits once war commenced and the author believes the Ottoman Black Sea merchant shipping was in reality one-half the total tonnage cited in pre-war 1914. The corresponding tonnage reduction would increase the loss percentage to 82 percent and such shipping losses would quickly lead to the commodity shortages evident at Istanbul in 1916.

The gunboat diplomacy that England exhibited against a friendly, neutral Ottoman Empire can be illustrated by how the British reacted in Mesopotamia. As the British annoyed the German-advised neutral Ottoman fleet at the Dardanelles, a British fleet set out from India. The British ship HMS Espiègle violated Ottoman sovereignty on 29 September 1914 by sailing up the Shatt-a-Arab waterway. When requested to leave Ottoman territorial waters on 7 October, the British commander declined. By 7 October the follow on forces arrived in HMS Dalhousie and HMS Odin. An additional demand to depart Ottoman territorial waters was delivered on 14 October, but the British refused to leave by the deadline of 21 October. ${ }^{493}$ The Indian government was also tasked by London to provide troops on 2 October for seizing neutral Ottoman territory. This force

${ }^{493}$ A.J. Baker, The Bastard War: The Mesopotamian Campaign of 1914-1918 (New York: The Dial Press, 1967), 18-21. 
was conveniently in place when war "officially" commenced and landed on Ottoman territory in Mesopotamia on 4 November. ${ }^{494}$

The stopping of Ottoman naval and commercial traffic in the Dardanelles, along with the blatant violation of Ottoman sovereignty in the Mesopotamian region, suggest that England hoped to provoke Ottoman military action in order to justify morally the dismemberment of the Ottoman Empire. The fact that the Ottomans did not succumb to British gunboat harassment is evidence that Istanbul desired to avoid the European war. The urgency London towards the Mesopotamian region could have been due to prior dealings with St. Petersburg whereas the region was divided among Entente allies and Britain's action suggest a fear that Russia might seize additional territory from Russiaoccupied Persia (Iran). The Russian war correspondent for the Russkia Vedommosti newspaper of Moscow, Vladimir Jabotinsky, writes in 1917, ". . If we look deeper, we see at once why Russia wants fortresses in the Near East. She wants them because of her need to push towards the warm seas, through the Straits or through the mountain chains of Armenia. The real cause of the Russo-Austrian conflict was the problem of further partition of the Ottoman Empire. ${ }^{1495}$ That view is also shared by George Cassar in The French and the Dardanelles. French political leaders were convinced that Churchill's drive up the Dardanelles was a cover for London's to control the region from Egypt through Mesopotamia and the Persian Gulf to India. London could argue that, since

${ }^{404}$ Ibid., 25-26.

${ }^{495}$ Vladimir Jabotinsky, Turkey and the War (London: T. Fisher Unwin, Ltd., 1917), 59 . 
British ships and troops secured the Dardanelles, the English should fashion the peace accords with the Porte. The real losers in such a scenario, where Ottoman authority was supplanted by British, is the French. The agreement fashioned on the Agamemnon resulted in exactly that expulsion of French control.

England would have never attempted to intimidate by sea a nation capable of inflicting damage upon the it's fleet. British naval commanders knew the status of Ottoman naval forces and had no respect for a navy that the English themselves directed for almost fifty years. Ottoman naval orders were good for English shipyards, but a strong Ottoman navy would be a threat to British imperialism. The time the Germans had some influence upon the Ottoman navy was brief compared to that of the British. Total German control did not occur until September 1914 and it ended with the Agamemnon agreement in October 1918. In this brief time, the hallmark of the German control was effective communication. In the Dardanelles defense the Ottoman navy and army cooperated in operations, troop movements, defense and logistics, in a manner never experienced under British control. British naval tactics used by the Ottomans excluded input from army commanders. This non-communication in the Balkan War cost Ottoman land forces several opportunities to stem the assault from Bulgarian and Greek forces. German tactics, inspired by Usedom, had both navy and army in the communications loop. This allowed forces to be rushed to the scene of assault quickly, and it allowed coordinated defensive measures, enabling the numerically and logistically strapped Porte to concentrate resources where needed. Under British guidance, joint service coordination on such a scale was unknown. 
Under German control, training and practical experience increased navy proficiency. Ottoman naval vessels offered more sorties, fought and won battles, and carried out an operational tempo second to none in the Mediterranean theater. All this would have been impossible without professional direction from officers dedicated to winning: direction the British did not provide. To place all the success with Souchon or any foreign naval mission would be erroneous. The British naval mission withdrew during the Italian and Balkan wars, leaving Ottoman naval commanders fully in charge. The Red Sea battles clearly showed Istanbul's willingness to fight. The covert resupply of forces in Tripolitania via France and Tunisia demonstrates a maturing view of sea power. Ottoman gunfire support in the Black Sea and the Sea of Marmara demonstrates the Mahan view of naval force and the potential benefits derived from such platforms. Greek control of the Aegean littoral region was incomplete only because the Ottoman fleet sortied to do battle when the opportunity presented itself. Souchon's role in Ottoman naval development is peripheral at best. The Ottoman fleet was made battleready by German assistance, but to assist Germany, rather than the Ottomans. Usedom provided leadership and proof that multi-force cooperation could defeat a materially superior foe. The German advisors could not do everything and the trench work was clearly Ottoman.

The Black Sea operational tempo prevented Russia from landing troops around the Straits. Russian minefields around the Bosporus were laid to prevent passage of the Ottoman fleet, clearly demonstrating the respect Russian's had for the Sultan's navy. Had the Ottoman economy not faltered, the navy could have continued the fray once the 
captured Russian fleet had been acquired

In summary, the Ottoman navy entered the Twentieth Century incapable of defending the Empire. This failure to secure the peripheries ultimately led to the loss of territories too distant to defend. The British naval mission, along with incompetent Ottoman oversight, destroyed what should have been the empire's first line of defense: the Ottoman navy. Any German influence, regardless of political motives, created forces capable of combating Russia, a common enemy.

As the world raced into dreadnought-building for national pride and security, the Ottoman Empire spent huge sums trying to equal her traditional enemies, Greece and Russia. . Using tainted advice, the Porte expended large sums trying to secure the remaining empire. Capital ships, which the Ottomans could not produce but the British insisted upon, were painstakingly acquired. Smaller ships the Ottomans could fabricate and ultimately did utilize were discouraged by the British advisors. The Ottoman navy entered World War I badly balanced by years of mismanagement. Yet this force held on and fought the English-French fleets to a draw in the Dardanelles while dueling with the Russians in the Black Sea. 


\section{BIBLIOGRAPHY}

Albertini, Luigi Albertini. Origins of the War of 1914. London: Oxford University Press, 1952.

Ansel, Walter C. Ansel. "Naval Gunfire in Support of Landings: Lessons from Gallipoli." Proceedings (July 1932), 1001-1010.

Baker, A.J. The Bastard War: The Mesopotamian Campaign of 1914-1918. New York: The Dial Press, 1967.

Brassey, T.A. ed., The Naval Annual, 1909. Portsmoputh: J. Griffin and Co., 1909. Bülow, Prince Bernard von. Memoirs. London: Oxford Press, 1931. Cassar, George H. Cassar. The French and the Dardanelles: A Study of Failure in the Conduct of the War. London: George Allen \& Unwin Ltd., 1971. Cassavetti, D.J. Hellas and the Balkan Wars. London: T. Fisher Unwin, 1914. Chatterton, E. Keble Chatterton. Dardanelles Dilemma. London: Rich and Cowan, 1935.

Churchill, Winston. The Hinge of Fate. London: Houghton Mifflin Company, 1950. Churchill, Winston S. Churchill. The World Crisis. New York: Scribner's, 1923. Clausewitz, Carl von. On War. Trans. and ed. by M. Howard and P. Paret. Princeton: Princeton University Press, 1984.

Corbet, Julian S. Naval Operations. London: Longman, Green and Co., 1923. Costello, John. The Pacific War. New York: Rawson, Wade, 1981. Cowels, Virginia. The Romanovs. London: Harper \& Row, 1971. 
Cronon, David E. The Cabinet Of Josephus Daniels 1913-1921. Lincoln: University of Nebraska Press, 1963.

Dakin, Douglas Dakin. The Unification of Greece, 1770-1923. New York: St. Martin Press, 1972.

Daniels, Josephus. The Wilson Era Years of Peace, 1910-1917. Chapel Hill: The University of North Carolina Press, 1944.

Deist, Wilhelm. Flottenpolitik und Flottenpropaganda: Das Nachrichten Bureau des Reichsmarineamtes, 1897-1914. Stuttgart: Deutsche Verlagsantalt, 1976.

Department of the Navy, Campaigning. Washington: US Government Printing Office, 1990.

Department of the Navy, Understanding Soviet Naval Development. Washington, DC:

Government Printing Office, 1985.

Dickinson, Lowes. The International Anarchy, 1900-1914. New York: The Century Co., 1926.

Djemal, Ahmad. Memories of a Turkish Statesman 1913-1919. London: George H. Doran Co., 1922.

Dugdale, E.T.S. German Diplomatic Documents, 1871-1914. London: Harper \& Brothers, 1931.

Emin, Ahmed Emin. Turkey in the World War. New Haven, CT: Yale University Press, 1930.

Evans-Pritchard, E.E. The Sanusi of Cyrenaica. Oxford: Clarendon Press, 1949.

Falls, Cyrill. Armageddon: 1918. Philadelphia: J.B. Lippincott Company, 1964. 
Fenwick, Charles G. International Law. New York: Appleton-Century-Crofts, Inc., 1948.

Ferrer, Claude. Histoire de la Marine Française. Paris: Flammarion, 1956.

Finer, Herman Finer. Mussolini's Italy. Hamden, CT: Archon Books, 1935.

Flanagan, Brian P. "The History of the Ottoman Air Force in the Great War." Cross and Cockade Journal, XI (Summer-Winter 1970).

Fleming, Peter. The Fate of Admiral Kolchak. New York: Harcourt, Brace \& World, Inc., 1963.

Fortescue, Granville. What of the Dardanelles? London: Hudder and Stoughton, 1915.

Fuller, William C. The Quest for Exits. New York: The Free Press, 1992.

Fuller, William C. Strategy and Power in Russia: 1600-1914. New York: The Free Press, 1992.

Gardiner, Robert, ed. Conway's All the World's Fighting Ships 1906-1921. London:

Conway's Maritime Press, 1985. Reprint, London: Conway Maritime Press, 1992.

Giolitti, Giovanni. Memoirs of My Life. Trans. by Edward Storer. London: Oxford Press, 1923.

Gooch, G.P., and Harold Temperley. British Documents on the Origins of the War, 1898-1914. London: His Majesty's Stationary Office, 1933.

Gooch, G.P. History of Modern Europe, 1878-1919. New York: Henry Holt and Company, 1922. 
Gordon, Leland J. American Relations with Turkey, 1830-1930: An Economic Interpretation Philadelphia: University of Pennsylvania Press, 1932.

Görlitz, Walter, ed. The Kaiser and His Court: The Diaries, Notes, Books and Letters of Admiral Georg Alexander von Müller, Chief of the Naval Cabinet, 1914-1918.

New York: Harcourt, Brace and World, Inc., 1959.

Gorshkov, S.G. The Sea Power of the State. Annapolis: Naval Institute Press, 1976. Greger, René. The Russian Fleet, 1914-1917. London: Ian Allan Ltd., Shepperton, Surrey, 1972.

Griscom, Lloyd C. Diplomatically Speaking. Boston: Little, Brown, 1940.

Gromov, Felix, Fleet Admiral, Russian Federation Navy. "After Three Centuries." Proceedings, October 1996.

Güleryüz, Ahmet, and Bernd Langensiepen. The Ottoman Steam Navy, 1828-1923.

Annapolis, MD: Naval Institute Press, 1995.

Gunston, Bill, ed. Chronicle of Aviation. London: Chronicle Communication, Ltd., 1992.

Halpern, Paul G. Halpern, ed. The Keyes Papers. London: William Clowes \& Sons, 1972.

Halpern, Paul. The Mediterranean Naval Situation, 1908-1914. Cambridge, MA:

Harvard University Press, 1971.

Halpern, Paul G. A Naval History of World War One. Annapolis: Naval Institute Press, 
Halpern, Paul G., ed. The Royal Navy in the Mediterranean 1915-1918. Brookfield:

Gower Publishing Company, 1987.

Hashagen, Ernest. U-Boats Westward. New York: Putnam, 1931.

Hayes, Carlton J. H. A Political and Social History of Modern Europe. New York: The Macmillan Company, 1925.

Helmreich, Paul C. From Paris to Sevres: The Partition of the Ottoman Empire at the Peace Conference of 1919-1920. Columbus: Ohio State University Press, 1974. Hough, Richard Hough. The Great Dreadnought: The Story of the H.M.S. Agincourt, the Mightiest Battleship of World War I. New York: Harper and Row Publishers, 1966.

Hough, Richard. The Great War at Sea, 1914-1918. New York: Oxford University Press, 1983.

Hough, Richard Hough. History of the Modern Battleship: Dreadnought. New York: Macmillan Company, 1964.

Hovgaard, William. Modern History of Warships. London: Unwin Brothers, 1920.

Reprint, London: New Impressions, 1970.

Hovrihan, William J. "The Big Stick in Turkey: American Diplomacy and Naval Operations Against the Ottoman Empire, 1903-1904." Naval War College Review, September-October 1981.

Hurd, Archibald. Italian Sea-Power and the Great War. London: Constable and Company Ltd., 1918. 
Hythe, Viscount. The Naval Annual 1913. Portsmouth: J. Griffin \& Co., 1913. Reprint, New York: Arco Publishing Company, 1970.

Jabotinsky, Vladimir. Turkey and the War. London: T. Fisher Unwin, Ltd., 1917. Jane, Fred T., ed. Jane's Fighting Ships, 1900-1901. London: Sampson Low Marston, 1901. Reprint, New York: Arco Publishing Company, 1969. Jane, Fred T., ed. All the World's Fighting Ships 1906/07. London: Sampson Low Marston, 1907. Reprint, New York: Arco Publishing Company, 1969. Jane, Fred T., ed. Jane's Fighting Ships, 1910. London: Sampson Low Marston, 1910. Reprint, New York: Arco Publishing Company, 1969. Jane, Fred T. ed., Jane's Fighting Ships, 1911. London: Sampson Low Marston, 1911. Reprint, New York: Arco Publishing Company, 1969. Jane, Fred T., ed. Jane's Fighting Ships, 1914. London: Sampson Low Marston, 1914. Reprint, New York: Arco Publishing Company, 1969. Jelavich, Barbara. The Ottoman Empire, the Great Powers, and the Straits Question, 1870-1887. New York: The MacMillan Company, 1971. Kannengiesser, Hans. The Campaign in Gallipoli. London: Hutchinson, 1928. Kennett, Lee. The First Air War, 1914-1918. New York: The Free Press, 1991. Kerr, Mark E.F. The Navy in My Time. London: Rich and Cowan, 1933. Keyes, Sir Roger. Naval Memories. New York: Dutton, 1934. Layman, R.D. Before the Aircraft Carrier: The Development of Aviation Vessels, $1849-$ 1922. London: Conway Maritime Press, 1989. 
Lenczowski, George. The Middle East in World Affairs, 3rd ed. Ithaca, NY: Cornell University Press, 1962.

Liddle, Peter H. The Sailor's War, 1914-1918. London: Blandford Press, 1985. Lincoln, Bruce. In War's Dark Shadow: The Russians Before the Great War. New York: Dial Press, 1983.

Lumby, E.D.W. Lumby, ed. Policy and Operations in the Mediterranean 1912-1914. London: William Clowes and Sons, 1970.

Maffe, John Maffee. "Ivan Hugs Shores of Tripoli." The Washington Post, 25 February 1969.

Marder, Arthur Jacob. From The Dreadnought To Scapa Flow The Royal Navy In The Fisher Era, 1904-1919. London: Oxford University Press, 1961. Massey, Isabella M., ed. The Origins of the War of 1914. London: Oxford University Press, 1952.

McCarthy, Justin. Death and Exile: The Ethnic Cleansing of Ottoman Muslims, 18211922. Princeton: The Darwin Press, Inc., 1995.

McCarthy, Justin. "Imperialism and Nationalism." Louisville: University of Louisville, 1996.

McClure, W.K. McClure. Italy in North Africa: An Account of the Tripoli Enterprise.

London: Constable and Company Ltd., 1913.

McEntee, Col. Girald Lindsley, USA-R. Military History of the World War. New York: Charles Scribner's Sons, 1937. 
Meacham, Cdr. James A., U.S.N. "Four Mining Campaigns: An Historical Analysis of

the Decisions of the Commanders." Naval War College Review, June 1967, 95.

Mears, Elliot Grinnell. Modern Turkey. New York: The MacMillan Company, 1924.

Melia, Tomara Moser. U.S. Naval Mine Countermeasures, 1777-1991. Washington,

DC: Department of the Navy, Naval Historical Center, 1991.

Mercer, Lieutenant D.D., R.N. "Ships Versus Forts: Dardanelles, March 1915."

Proceedings (October 1932).

Moberly, F.J. Operations in Persia, 1914-1919. London: Her Majesty's Stationary Office, 1987.

Montgelas, Max, and Walther Schücking, eds. Outbreak of the World War, German Documents Collected by Karl Kautsky. New York: Oxford University Press, 1924.

Monroe, W.S. Turkey and the Turks. Boston: L.C. Page and Company, 1907.

Moorehead, Alan. Gallipoli. New York: Harper and Brothers Publishers, 1956.

Moran, Charles Moran. The Sea of Memories. New York: Scribner, 1942.

Morgenthau, Henry. Ambassador Morgenthau's Story. New York: Doubleday, Page \& Company, 1918.

Morgenthau, Henry. Secrets of the Bosporus. London: Hutchinson, 1918.

Mylonalas, George E. The Balkan Wars. St. Louis: Eden Publishing House, 1946.

Nekrasov, George. North of Gallipoli: The Black Sea Fleet at War, 1914-1917. New

York: Columbia University Press, 1992. 
Newbolt, Henry Newbolt. Naval Operations. New York: Longman's, Green and Co., 1931.

Newman, Bernard. Mediterranean Background. London: Hale, 1949.

Page, Thomas Nelson. Italy and the World War. New York: Charles Scribner's and Sons, 1920.

Paneth, Phillip. Turkey: Decadence and Rebirth. London: Alliance Press, Ltd., 1943.

Parks, O.J., and Maurice Prendergast, eds. Jane's Fighting Ships, 1919. London:

Sampson Low Marston, 1919. Reprint, New York: Arco Publishing Company, 1969.

Pears, Sir Edwin. Forty Years in Constantinople 1873-1915. New York: D. Appleton and Company, 1916.

Peters, Emrys L. Peters. The Bedouin of Cyrenaica. London: Cambridge University Press, 1990.

Pribram, Dr. Alfred Francis. The Secret Treaties of Austria-Hungary, 1879-1914.

London: Oxford University Press, 1920.

Rankin, K.L. "The Battle of Helles and Lemnos." Proceeding (May 1940).

Schurman, Jacob Gould. The Balkan Wars 1912-1913. London: Oxford University

Press, 1914.

Shotwell, James T., and Francis Deak, Turkey at the Straits. New York: The MacMillan Company, 1940.

Silverstone, Paul H. U.S. Warships of World War I. New York: Doubleday \& Company, Inc., 1970. 
Simpson, Mitchell. Admiral Harold R. Stark. Columbia: University of South Carolina Press, 1989.

Smith, Denis Mack. Italy: A Modern History. Ann Arbor, MI: University of Michigan Press, 1959.

Spector, Ivan. The Soviet Union and the Muslim World. Seattle: University of Washington Press, 1959.

Steward, Archibald, and Charles J.E. Peshall. Immortal Gamble. London: Black and Co., 1917.

Terraine, John. The U-Boat Wars, 1916-1945. New York: G.P. Putnam \& Sons, 1961.

Thomas, Lowell. Raiders of the Deep. New York: Garden City Publishing Company, 1928.

Thompson, Holland Thompson, ed. The World War. New York: The Grolier Society, 1921.

The Times, History of the War. London: The Times, 1915.

Tirpitz, Alfred von. My Memories. New York: Dodd Mead, 1919.

Trask, David F. Captains and Cabinets: Anglo-American Naval Relations, 1917-1918.

Columbia: University of Missouri Press, 1972.

Trumpener, Ulrich. Germany and the Ottoman Empire 1914-1916. Princeton: Princeton University Press, 1968.

Turkish Naval Forces Command. Trans. by Tayfun Isevi. Ottoman Naval Signal Code Book. Ankara: Naval Forces HQ Press, 1995. 
United States, Papers Relating to the Foreign Relations of the United States.

Supplement. Washington, DC: Government Printing Office, 1928.

US Navy Department. Dictionary of American Naval Fighting Ships. Washington: U.S.

Government Printing Office, 1969.

Vat, der van Dan. Gentleman of War: The Amazing Story of Captain Karl Von Müller

and the S.M.S. Emden. New York: William Morrow and Company, Inc., 1984.

Van der Vat, Dan. The Ship That Changed the World. Bethesda, MD: Adler \& Adler, 1986.

Walder, David. The Chanak Affair. London: The Macmillan Company, 1969.

Weber, Frank G. Eagles on the Crescent: Germany, Austria and the Diplomacy of the Turkish Alliance 1914-1918. London: Cornell University Press, 1970.

Weir, Gary. Building the Kaiser's Navy: The Imperial Naval Office and German Industry in the von Tirpitz Era, 1890-1919. Annapolis: Naval Institute Press, 1992.

Wells, H.G. The Outline of History. New York: Review of Reviews Company, 1924.

Wester-Wemyss, Baron Rosslyn E.W. The Navy in the Dardanelles Campaign. London:

Hodder and Stoughton, 1924.

Whalen, LCDR John F., USNR. "The Ghost of Rebel Torpedoes." Proceedings, September 1996.

Woodward, David. The Russians at Sea. New York: Frederick Praeger, 1965. 


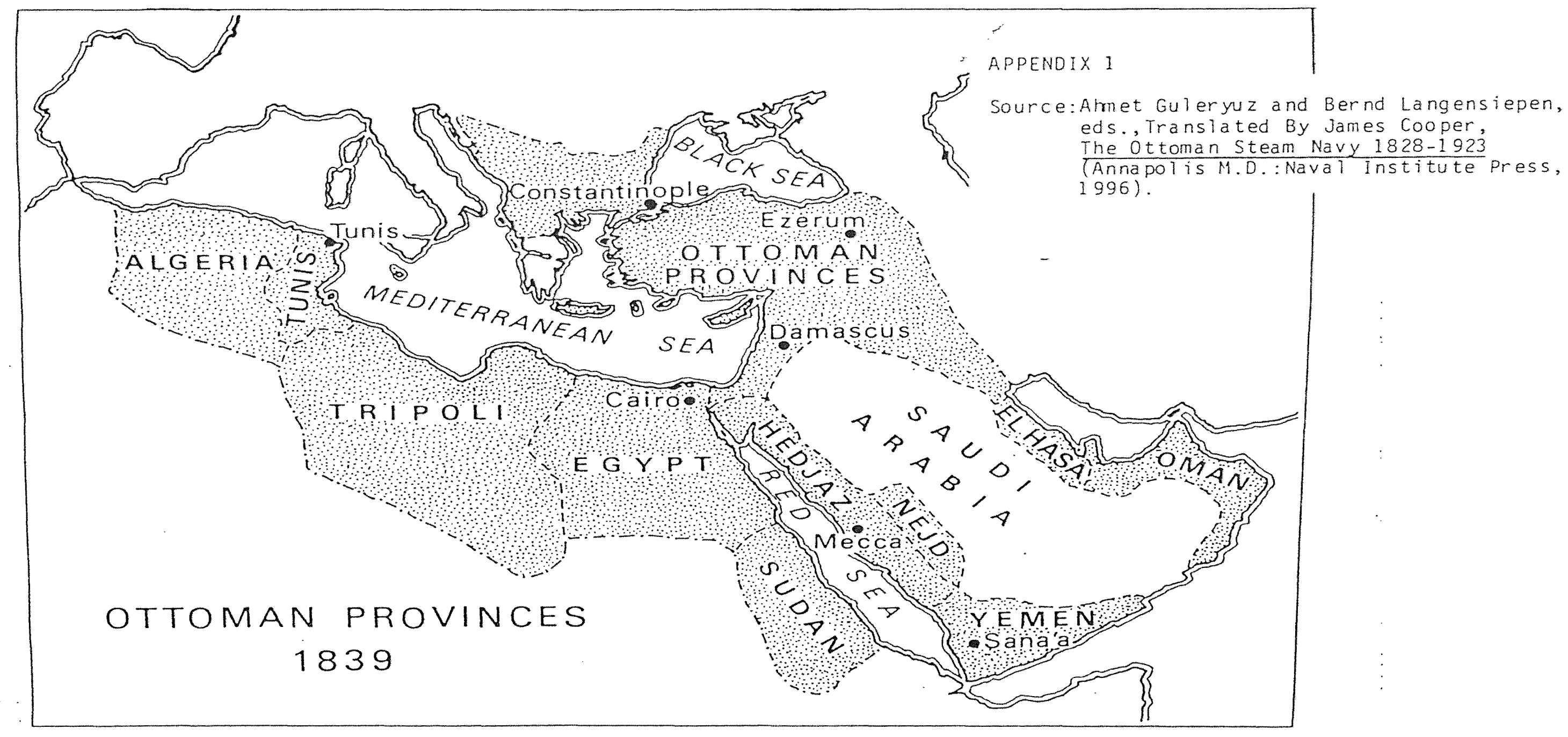




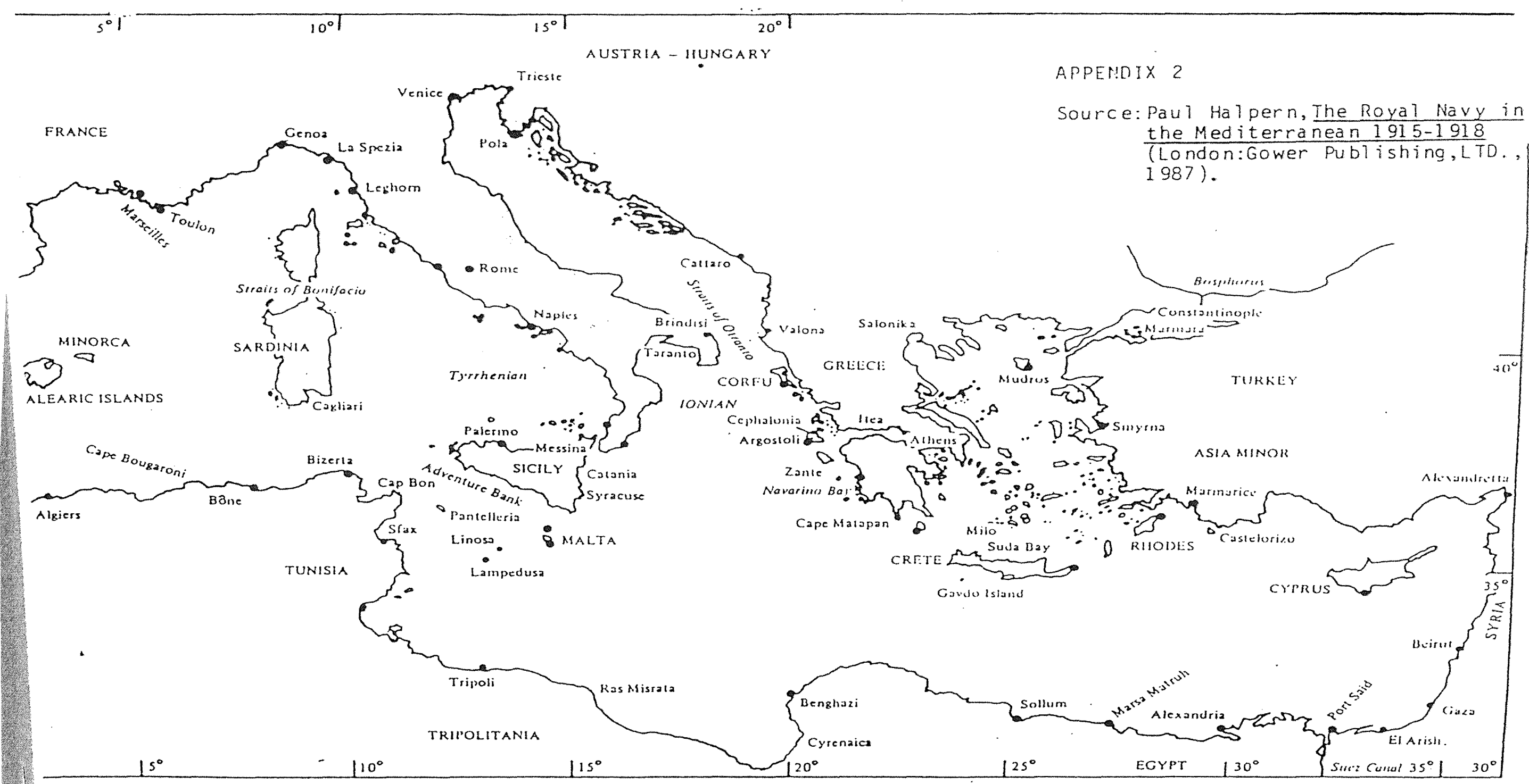

THE CENTRAL MEDITERRANEAN AREA IN I 911 


\section{APPENDIX 3}

\section{OTTOMAN FLEET ORGANIZATION, OCTOBER $1911^{496}$}

Fleet Commander: Rear Admiral Cibaliti Tahir Mehmet Bey

British Advisor: Admiral Williams, R.N.

Istanbul

Division Commander - Rear Admiral Tahir

Barbaros Hayreddin

Torgud Reis

Mesudiye

Asar I Tevfik

Hamidiye

Mecidiye

Flotilla

C.O. Captain Hakki

Muavent-i

Gayret-i Vataniye

Numune-i Hamiyet

Yadigar-i Millet

Tasoz

Samsum

Yarhisar

Izmir Detachment

C.O. Captain Hikmet

Muin-i Zafer

Yunus

Selanik

Timsah

Izzeddin

Roma

Arsipel

Trabson 
Selanik Detachment

C.O. Captain Bekir Rasit

Feth-i Bulend

Fuad

Selanik

Surat

Teshilat Katerin

Trablusgrab Detachment

C.O. Captain Ahmet

Seyyad-i Derya

Lake Iskodra Detachment

C.O. Senior Commander Yahya

Gor

Iskodra

Preveze Detachment

C.O. Captain Tevfik

Hamidiye

Alpagot

Tokad

Antalya

Trablus

Gunboat No. 9

Gunboat No. 10

Kizildeniz Group

C.O. Captain Hamid

Peyk-i Sevket

Ordu

Bafra

Ayintab

Malatya

Gokcedag

Refahiye

Spika

Beyrut 
Moha

Halic

Yozgat

Kastamonu

Taskopru

Bahriye

Ahmer

Beyrut Detachment

No C.O.

Avnillah

Ankara

Source: Ahmet Güleryüz and Bernd Langensiepen, eds., The Ottoman Steam Navy 18281923, trans. by James Cooper (Annapolis, MD: Naval Institute Press, 1996), 194-195. 


\section{APPENDIX 4}

OTTOMAN FLEET DISPOSITION AS OF 10 OCTOBER 1912

MINISTER OF MARINE

GENERAL SALIH PASHA

NAVAL MINISTER

ADMIRAL HALIL PASHA

OTTOMAN FLEET COMMANDER, BOSPORUS FLEET COMMANDER, REAR ADMIRAL MEHMET BEY

DARDANELLES FIRST COMMANDER

CAPTAIN TEVIK

BLACK SEA FLEET COMMANDER

CAPTAIN HUSEYIN RAUF

NAVAL ADVISOR TO THE OTTOMAN MINISTRY OF MARINE

ADMIRAL SIR HENRY LIMPUS

BASE

stanbul-HAYDARPASA

BARBAROS HAYREDDIN, TORGUD REIS, MECIDIYE

stanbul-HALIC (SHIPYARD)

GAYRET-I VATANIYE, BERKEFSAN, PELENG-I DERYA, BERK-I SATVET,

DRAC, NURULBAHIR

stanbul - HALIL

ICLALIYE, BASRA

tanbul - DOLMABHCE 


\section{ERTUGRUL}

Istanbul - KABATAS

ISTANBUL

Istanbul - ARNAVUT KOY

SOGUTLU

BOSPOSUR - BUYUKDERE

YADGAR-I MILLET, MUAVENET-I MILLIYE, NUMUNE-I HAMIYET,

SAMSUN, TASOZ, SIVRIMISAR, DEMIRNISAR, SULTANHISAR, MUSUL,

UTAHYA, ZUHAF, NEVSEHIR, TIRIMUJGAN

SINOP

HAMIDIYE

CANAKKALE

MESUDIYE, ASAR-I TEVFIK, YARHISAR, HAMIDABAD, AKHISAR

\section{PREVEZE}

ANTALYA, TOKAT, NO. 9 AND NO. 11 (MOTOR BOATS)

\section{SELANIK}

FETH-I BULEND, FAUD

IZMIR

MUIN-I ZAFER, YUNUS, TIMSAH, IZZEDDIN, TRABZON

SUEZ (INTERNED BY BRITISH AS OF 29 SEPTEMBER 1911)

PEYK-I SEVKET, BEYRUT, MALATYA, TASKOPRU, YOZGAT 


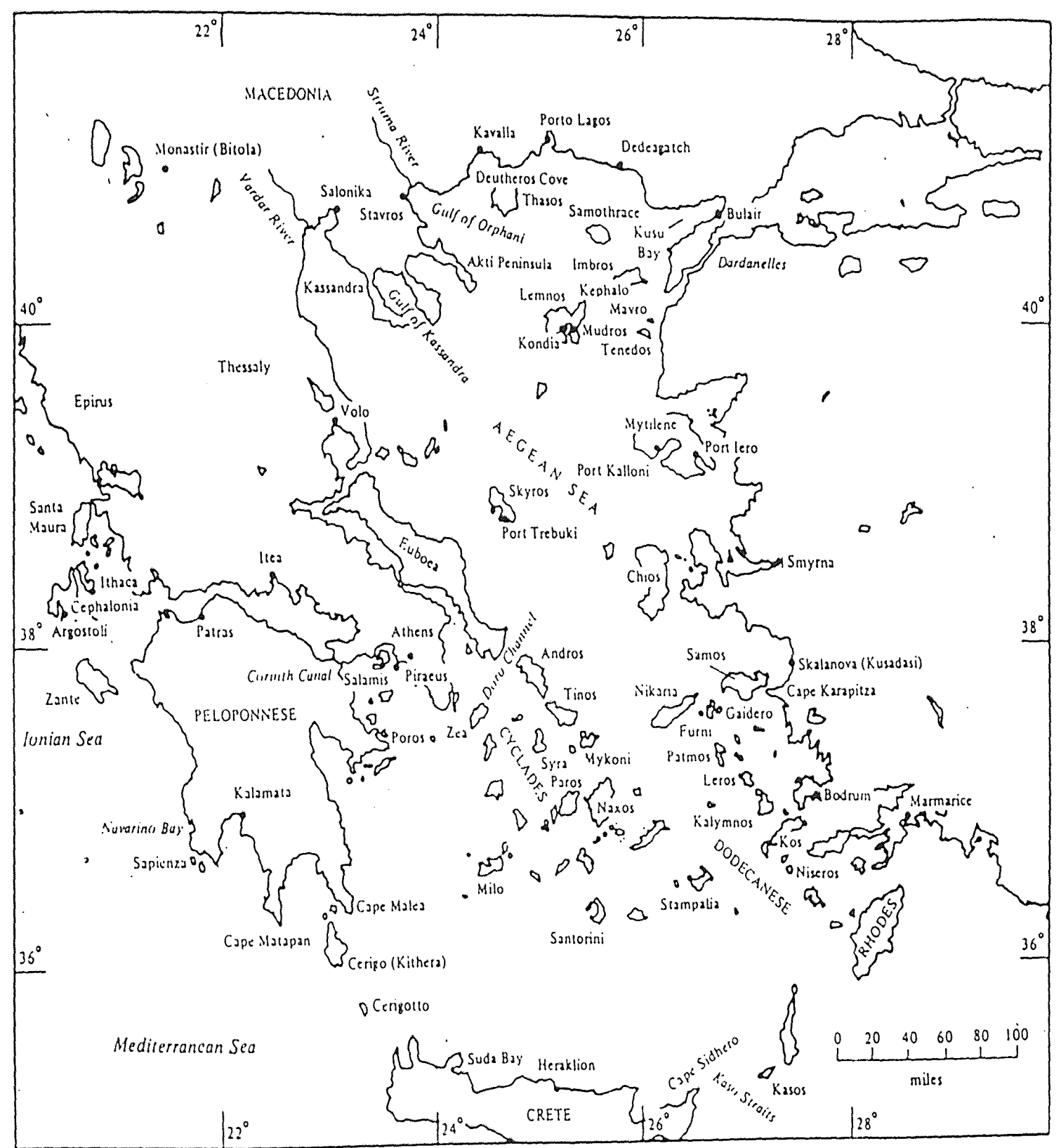

The Aegean

APPENDIX 5

Source:Paul Hal pern, The Royal Navy in

the Mediterranean 1915-1918

London:Gower Publishing LTD., 1987). 


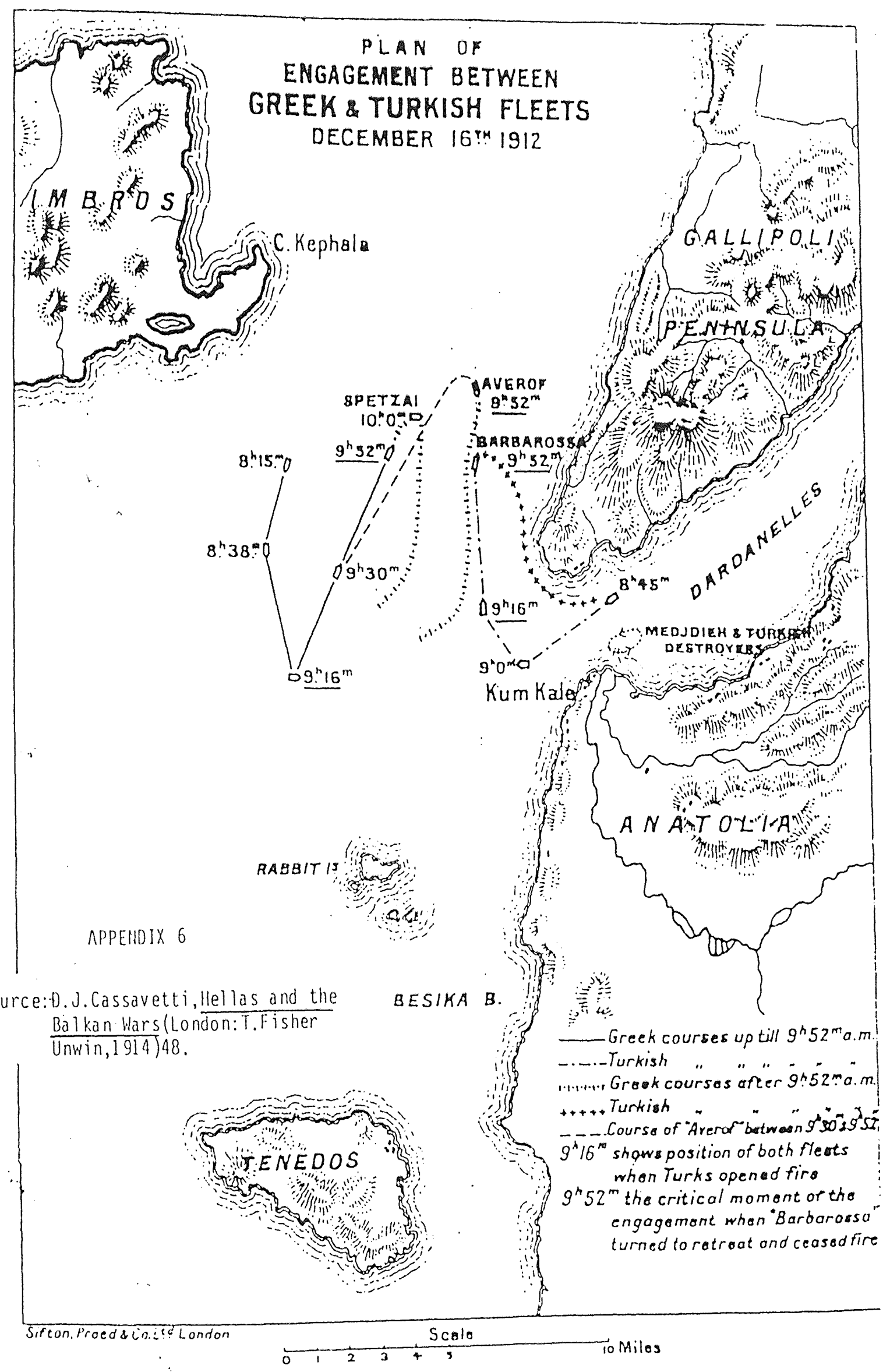




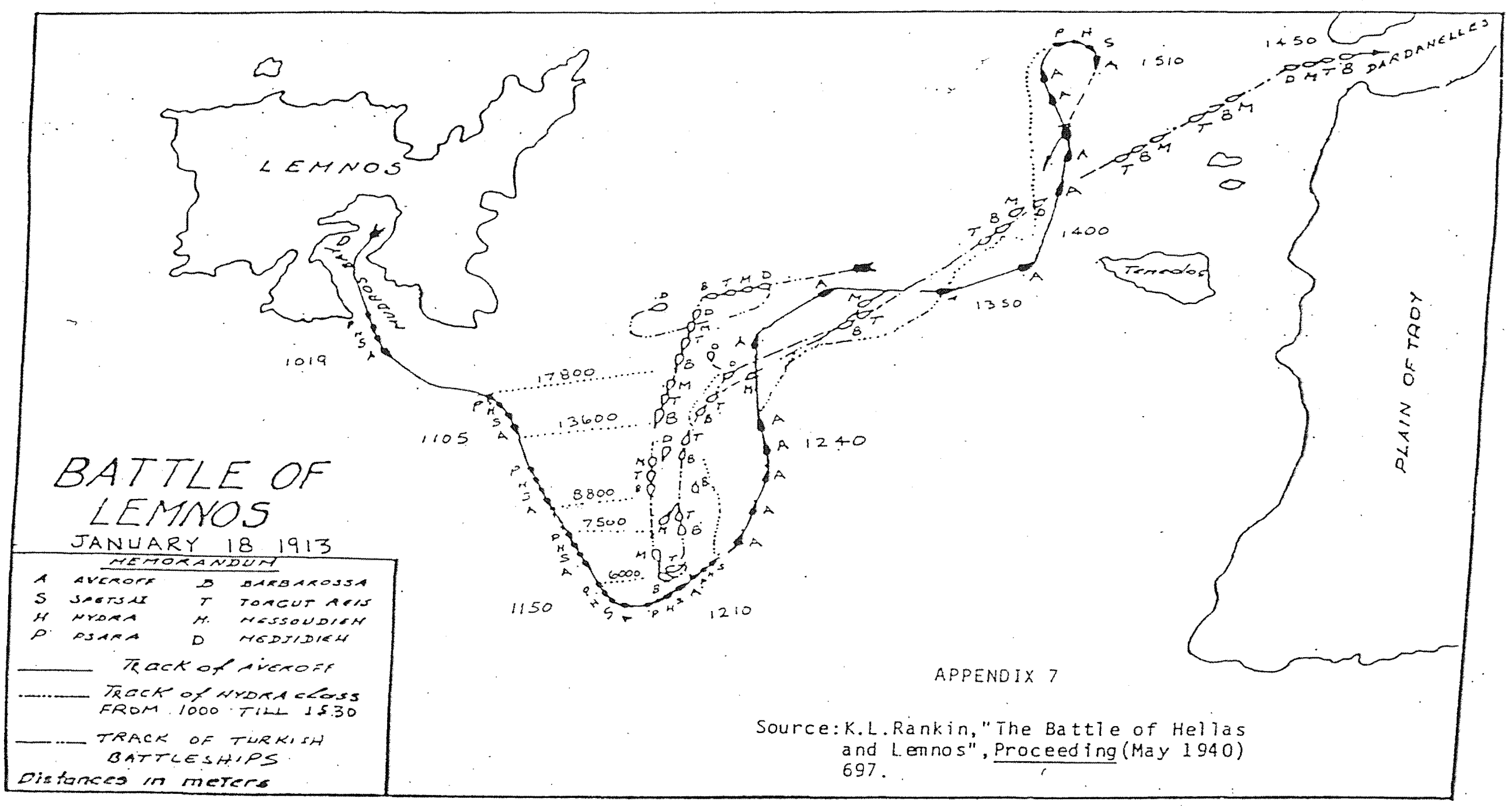




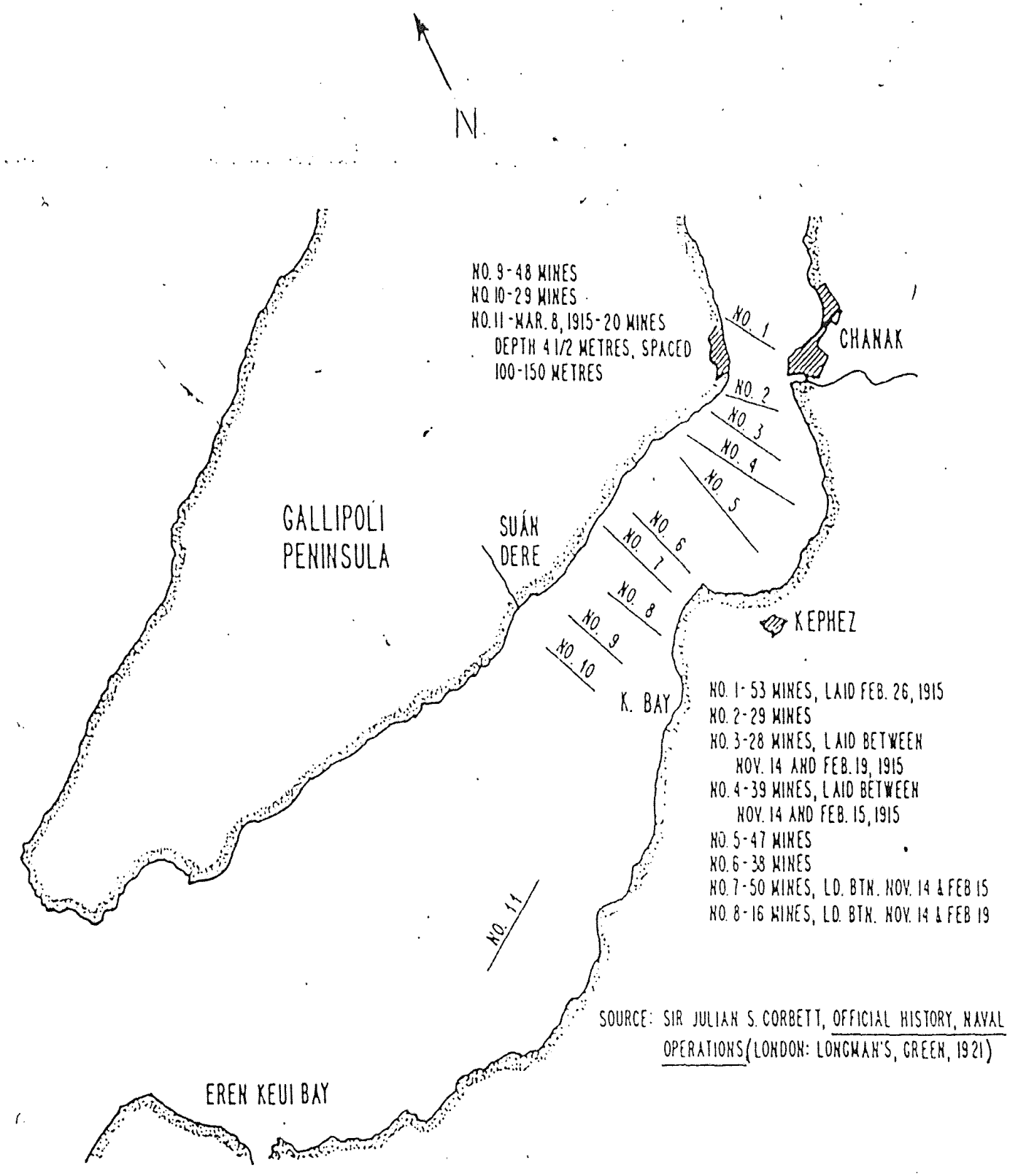

APPENDIX 8

OTTOMAN MINE LINES AS OF 20 MARCH 1915 


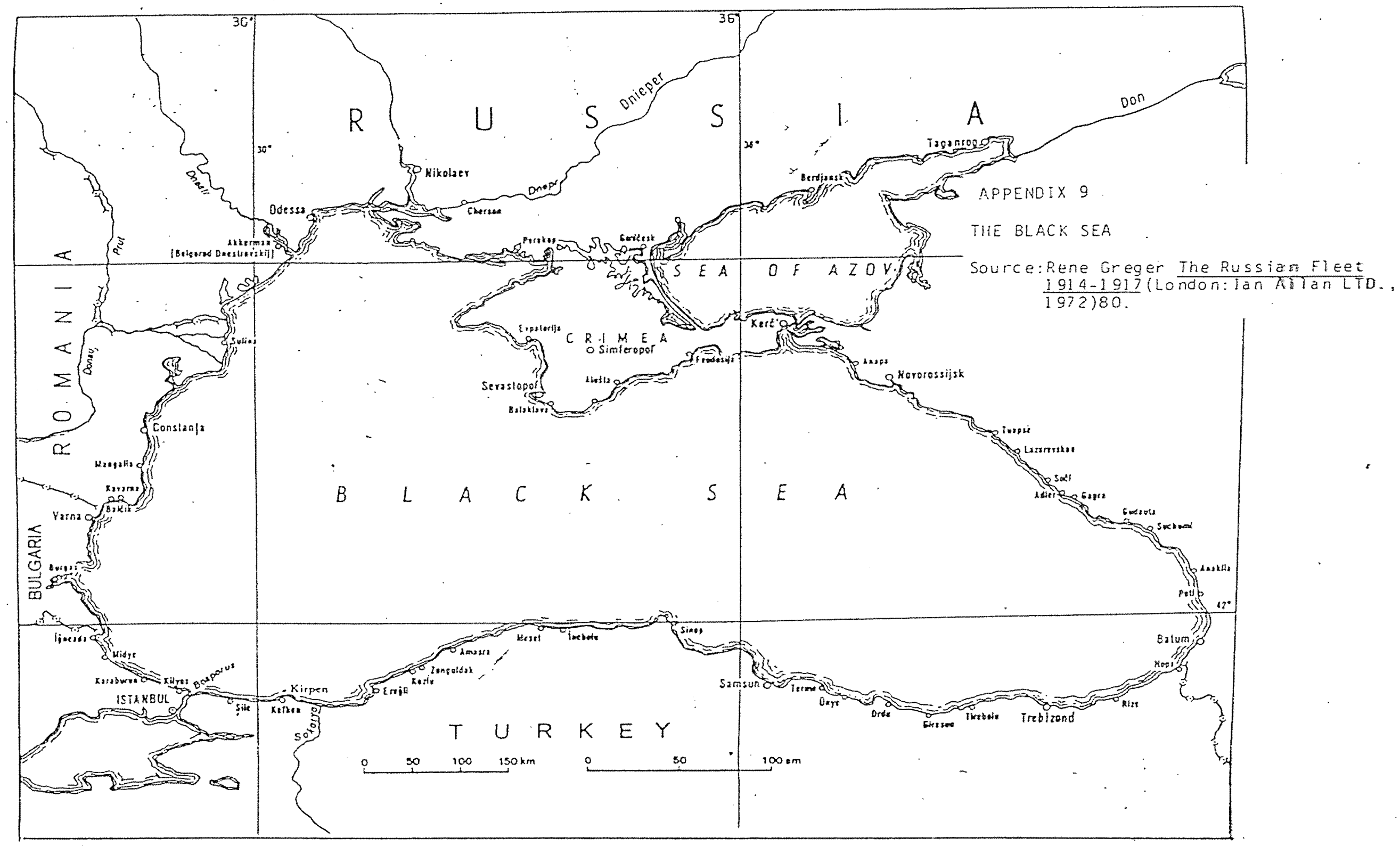




\section{APPENDIX 10}

\section{OTTOMAN NAVAL DISPOSITION AS OF 1 OCTOBER 1914}

Squadron I

Commanding Officer: Admiral Souchon

Armored

Yavuz Mesudiye

Hayreddin

Torgud Reis

Destroyers
Numune-i Hamiyet
Muavent-i Milliye
Gayret-i Vatniye
Yadirgar-i Millet

\section{Torpedo Boats}

Drac

Kutanya

Musul

Akhisar

Squadron II

Commanding Officer: Admiral Arif

Armored

Midilli

Hamidiye

Peyk-i Sevket Berk-i Satvet

\section{Destroyers}

Samsun

Tasoz

Basra

Yar Hisar

Torpedo Boats

Sultan Hisar

Demirhisar

Sivrihisar 


\section{VITA}

The author, Karl Wilhelm Augustus Darr, is the son of Robert Patrick Darr and Marie (Wilson) Darr. He was born 21 September 1957 in Louisville, Kentucky.

His elementary education was obtained at St. Philip Neri Catholic School, junior high at Manley Junior High School, and secondary education at Victor H. DuPont High School, Louisville, Kentucky, where he graduated in 1976.

In December 1976, he enlisted into the United States Navy, being discharged in February 1981, and reentered the Naval Reserves in 1984. He presently holds the rank of Signalman Chief Petty Officer In June 1981, he entered Louisville Technical Institute and in September 1983 received the degree of Associate in Architectural Engineering. In September 1988, he began attending the University of Louisville, and in May 1992 he received the degree of Bachelor of Arts with a major in Political Science. He was a member of the Mock Trial Team in 1990. In 1996 he was accepted into the Graduate program at the University of Louisville. In 1997, he became a member of the History Honor Society Phi Alpha Beta. He is a member of the Filson Historical Club in Louisville, Kentucky.

In addition, he is a life member of the Navy Records Society of the United Kingdom, along with the United States Naval Institute. Additionally, he was elected President of the Naval Enlisted Reserve Association chapter in Louisville. The author is married to Robin Cushing-Darr and has four children: Lisa, Rebecca, Laura, and Aaron. 